\title{
LA-5202-MS
}

INFORMAL REPORT

$u e^{n+2 t}$

Thermodynamic Analysis of MHW Space Electric Power Generator

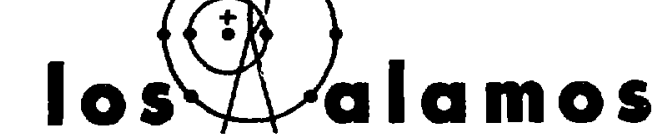

scientific laboratory

of the University of California LOS ALAMOS, NEW MEXICO 87544

$\downarrow$ 
This report was prepared as an account of work sponsored by the United States Government. Neither the United States nor the United States Atomic Energy Commission, nor any of their employees, nor any of their contractors, subcontractors, or their employees, makes any warranty, express or implied, or assumes any legal liability or responsibility for the accuracy, completeness or usefulness of any information, apparatus, product or process dis. closed, or represents that its use would not infringe privately owned rights.

In the interest of prompt distritution, this LAMS report was not edited by the Technical Information statf.

Printed in the United States of America. Available trom National Technical Information Service

U. S. Department of Commerce

5285 Port Royal Roxd

Springtield, Virginia 22151

Price: Printed Copy \$3.00: Microtiche $\$ 0.95$ 


\title{
LA.5202-MS
}

Informal Report

UC. 4 \& 23

ISSUED: March 1973

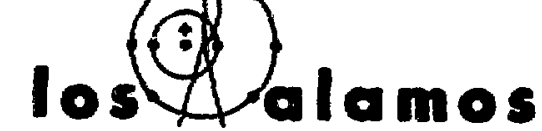

eqentitie laboratery

of the University of Cellfernio

los alamos. HEW MExico \$7S4A

l.

\section{Thermodynamic Analysis of MHW Space Electric Power Generator}

\author{
by
}

R. A. Kent

This work sponsered by the lsotopes Technotogy Branch, Space Nuclser Systems, US Atomic Eneroy Commission.

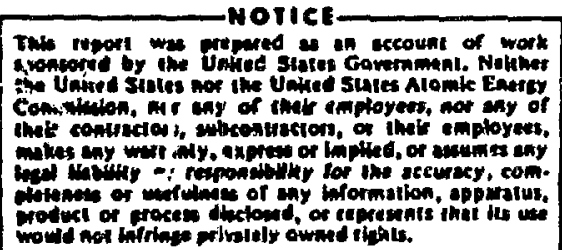




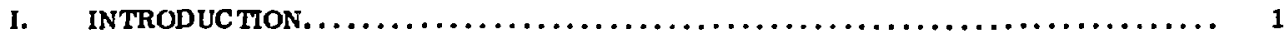

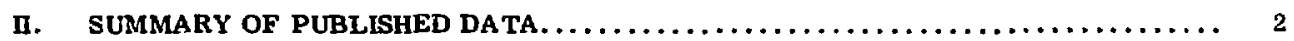

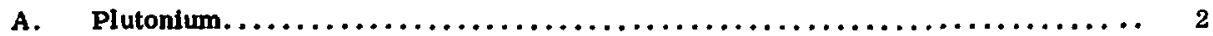

1. Thermodynamics................................. ?

2. Vapor Pressure Measurements.......................

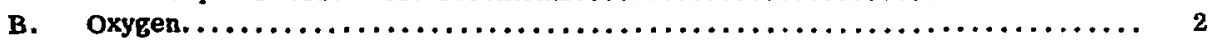

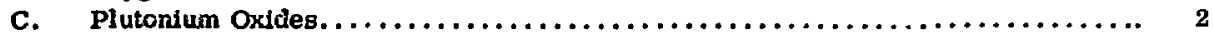

1. Thermodynamic Functions for $\left\langle\mathrm{PuO}_{2}>\ldots \ldots \ldots \ldots \ldots \ldots \ldots \ldots \ldots \ldots \ldots \ldots\right.$

2. Free Energy Values for $\left\langle\mathrm{PuO}_{2}-\mathrm{x}\right\rangle$ Species and Partial Molar Free

Energies for Oxygen in $\left\langle\mathrm{PuO}_{2-\mathrm{x}}\right\rangle$ Species $\ldots \ldots \ldots \ldots \ldots \ldots \ldots \ldots \ldots \ldots$

3. Free Energies of Formation for (PuO) and $\left(\mathrm{PuO}_{\mathrm{j}}\right) \ldots \ldots \ldots \ldots \ldots \ldots \ldots \ldots \ldots$

4. Calculated Vapor Pressure Values above Various $\left\langle\mathrm{PuO}_{2}-\mathrm{x}\right\rangle$ Compositions . 3

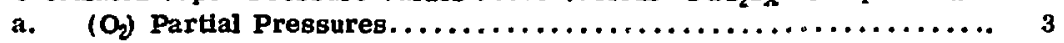

b. (PuO) Partlal Pressures.......................... 3

c. (Pu) Partial Pressures............................ 3

d. $\left(\right.$ PuO $\left._{2}\right)$ Partial Pressures............................ 4

e. Congruency of Vaporization. .......................... 4

5. Experimental Vapor Pressures. ........................ 4

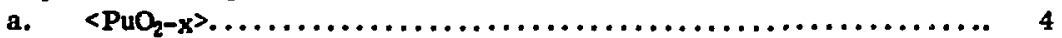

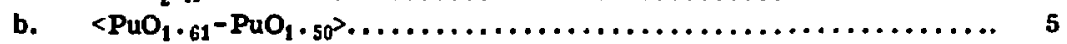

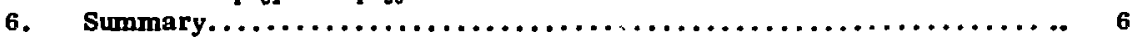

D. Curbon. $\ldots \ldots \ldots \ldots \ldots \ldots \ldots \ldots \ldots \ldots \ldots \ldots \ldots \ldots \ldots \ldots \ldots \ldots \ldots \ldots \ldots \ldots \ldots \ldots$ 6

E. Iridium $\ldots \ldots \ldots \ldots \ldots \ldots \ldots \ldots \ldots \ldots \ldots \ldots \ldots \ldots \ldots \ldots \ldots \ldots \ldots \ldots \ldots \ldots \ldots \ldots$

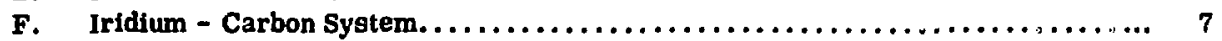

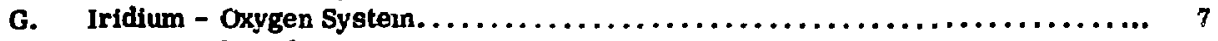

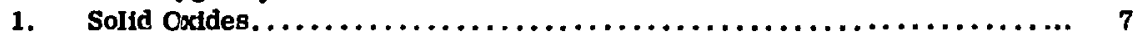

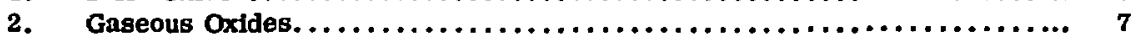

3. Kinetic Studies $\ldots \ldots \ldots \ldots \ldots \ldots \ldots \ldots \ldots \ldots \ldots \ldots \ldots \ldots \ldots \ldots \ldots \ldots \ldots \ldots$

4. Summary..................................... 9

H. Plutonium - Iridium System $\ldots \ldots \ldots \ldots \ldots \ldots \ldots \ldots \ldots \ldots \ldots \ldots \ldots \ldots \ldots \ldots \ldots \ldots . \ldots \ldots$

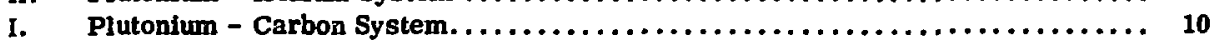

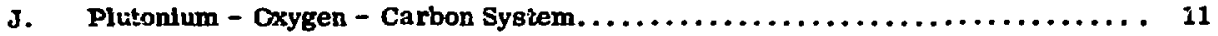

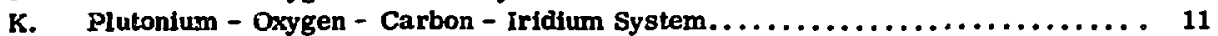

L. Miscellaneous $\ldots \ldots \ldots \ldots \ldots \ldots \ldots \ldots \ldots \ldots \ldots \ldots \ldots \ldots \ldots \ldots \ldots \ldots \ldots \ldots \ldots 11$

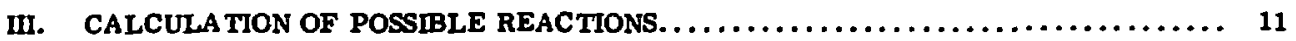

A. Basis for Calculations $\ldots \ldots \ldots \ldots \ldots \ldots \ldots \ldots \ldots \ldots \ldots \ldots \ldots \ldots \ldots \ldots \ldots \ldots \ldots 11$

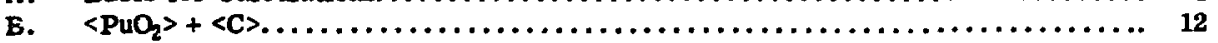

C. $\left\langle\mathrm{PuO}_{2}>+(\mathrm{CO}) \ldots \ldots \ldots \ldots \ldots \ldots \ldots \ldots \ldots \ldots \ldots \ldots \ldots \ldots \ldots \ldots \ldots \ldots \ldots \ldots \ldots \ldots\right.$

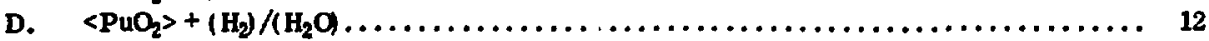

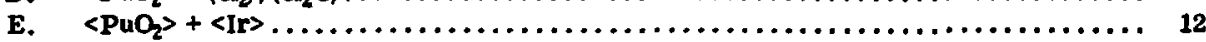

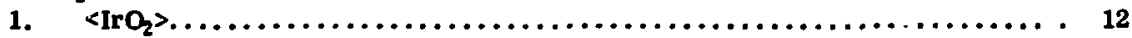

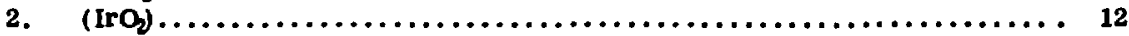

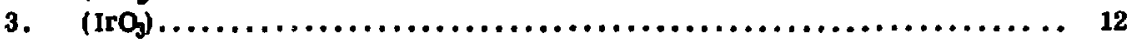

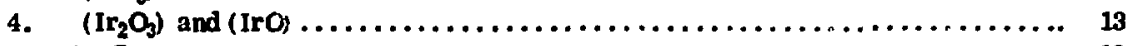

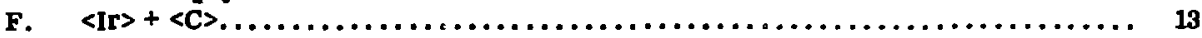

IV. THERMODYNAMIC ANALYSIS FOR A MHW-FSA $\ldots \ldots \ldots \ldots \ldots \ldots \ldots \ldots \ldots \ldots \ldots \ldots$

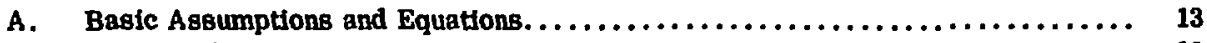

1. Fuel. ....................................... 13

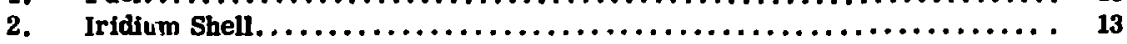

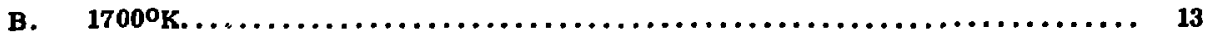

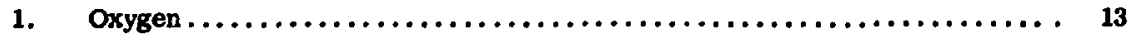

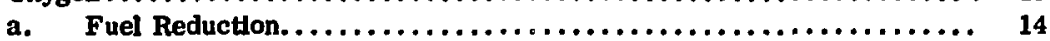

b. Effusion of $\left(O_{2}\right)$ from the FSA...................... 14

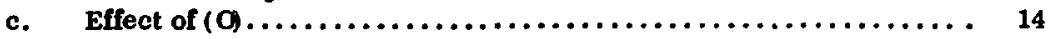

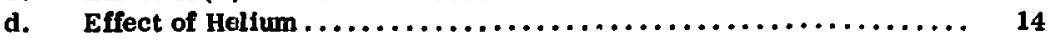

e. Reactions with the Iridium Shell...................... 14

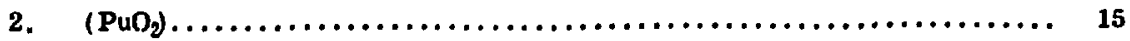




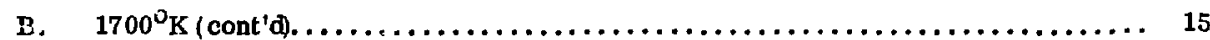

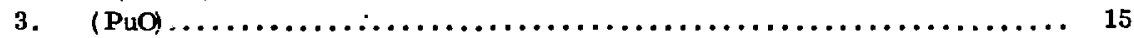

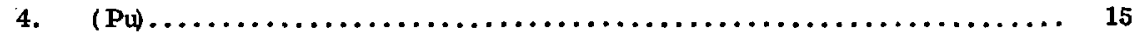

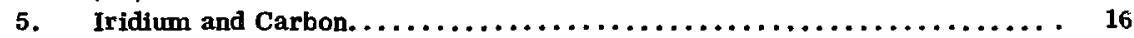

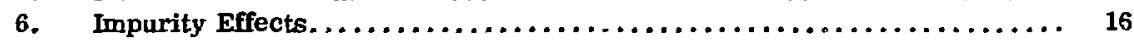

7. Summary.................................... 16

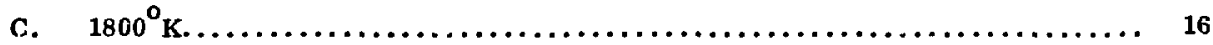

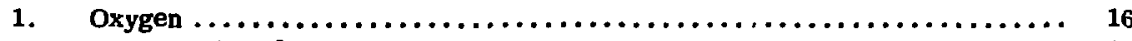

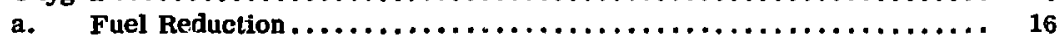

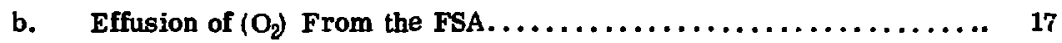

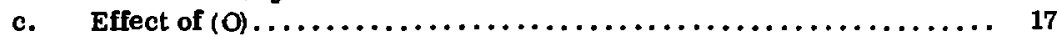

d. Effect of Helium $\ldots \ldots \ldots \ldots \ldots \ldots \ldots \ldots \ldots \ldots \ldots \ldots \ldots \ldots \ldots \ldots \ldots$

e. Reactions with the Irinlum Shell $\ldots \ldots \ldots \ldots \ldots \ldots \ldots \ldots \ldots \ldots \ldots \ldots$. 17

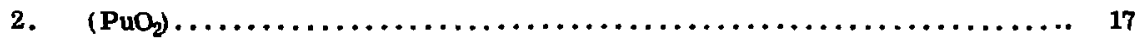

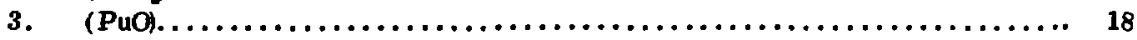

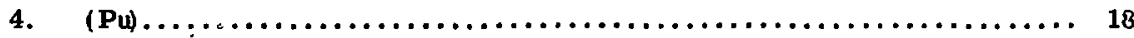

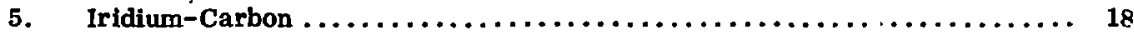

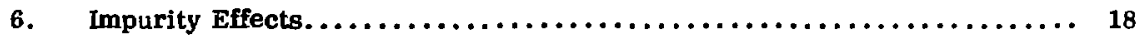

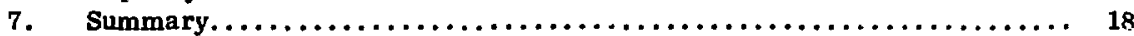

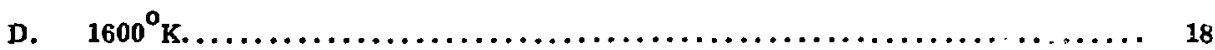

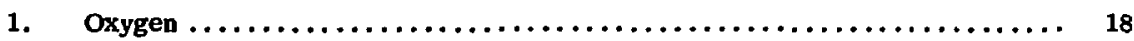

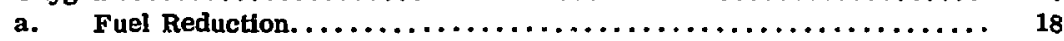

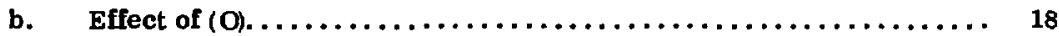

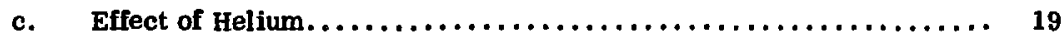

d. Reactions with the Iridium shell.................... 19

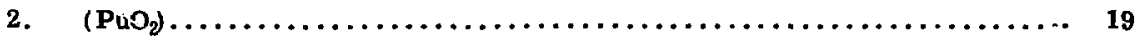

3. (PuO) $\ldots \ldots \ldots \ldots \ldots \ldots \ldots \ldots \ldots \ldots \ldots \ldots \ldots \ldots \ldots \ldots \ldots \ldots \ldots \ldots \ldots \ldots$

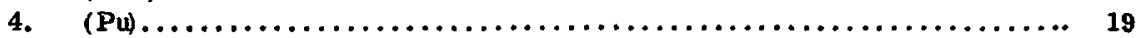

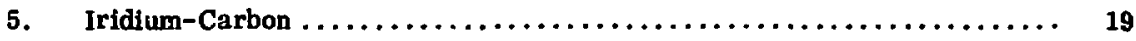

6. Impurity Effects................................. 19

7. $\quad$ Summary........................................ 19

E. $\quad$ Reentry......................................... 20

F. Reentry at $2000^{\circ} \mathrm{K}$ if the Fuel is $\left\langle\mathrm{PuO}_{2} .0\right\rangle \ldots \ldots \ldots \ldots \ldots \ldots \ldots \ldots \ldots \ldots \ldots$

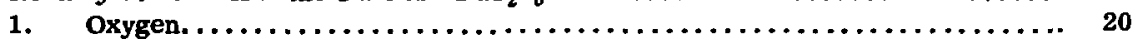

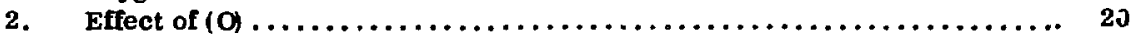

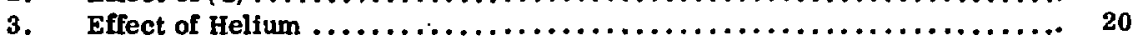

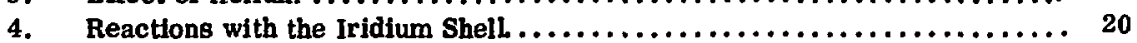

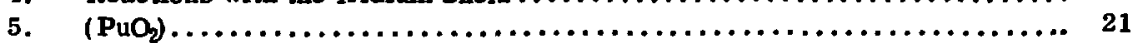

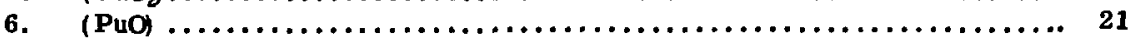

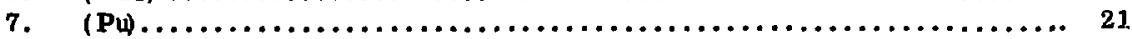

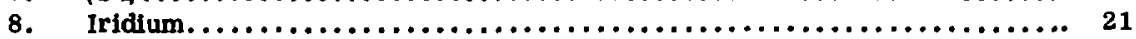

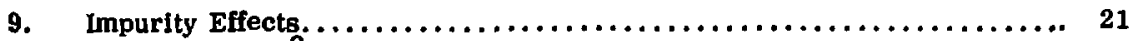

10. Reentry at $2000^{\circ} \mathrm{K}$ if the Fuel is $\left\langle\mathrm{PuO}_{1} \cdot s_{8}>\ldots \ldots \ldots \ldots \ldots \ldots \ldots \ldots \ldots \ldots 21\right.$

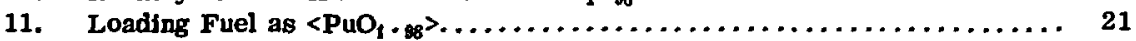

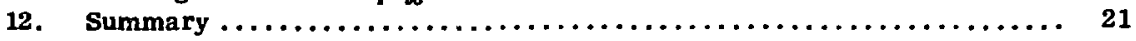

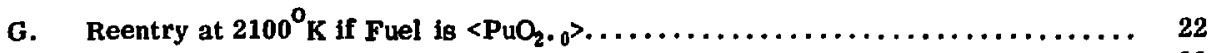

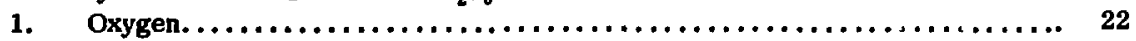

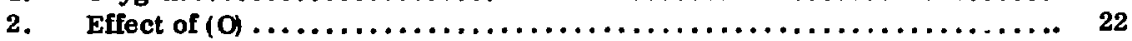

3. Effect of Hellum $\ldots \ldots \ldots \ldots \ldots \ldots \ldots \ldots \ldots \ldots \ldots \ldots \ldots \ldots \ldots \ldots \ldots \ldots \ldots, 22$

4. Reactions with the Irldfum Shell $\ldots \ldots \ldots \ldots \ldots \ldots \ldots \ldots \ldots \ldots \ldots \ldots \ldots \ldots, 22$

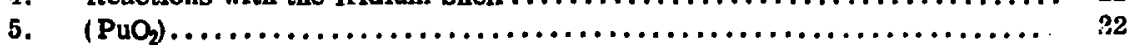

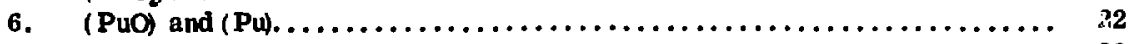

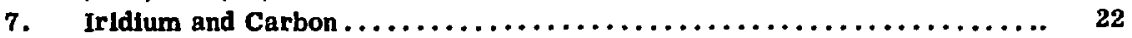

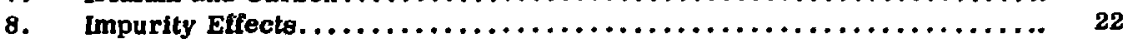

9. Reentry at $21000^{\circ}$ if the Fuel is $<\mathrm{PuO}_{1} \cdot \mathrm{sg}>\ldots \ldots \ldots \ldots \ldots \ldots \ldots \ldots \ldots \ldots, 22$ 
G. Reentry at $2100^{\circ} \mathrm{K}$ if Fuel is $\left\langle\mathrm{PuO}_{2.0}\right\rangle($ cont $\mathrm{d}) \ldots \ldots \ldots \ldots \ldots \ldots \ldots \ldots \ldots$

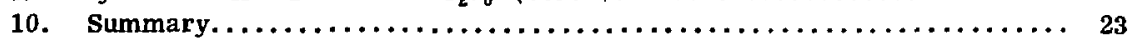

H. Reentry at $2200^{\circ} \mathrm{K}$ if the Fuel is $\left\langle\mathrm{PuO}_{2} \cdot \mathrm{o}\right\rangle \ldots \ldots \ldots \ldots \ldots \ldots \ldots \ldots \ldots \ldots \ldots$

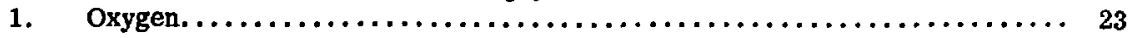

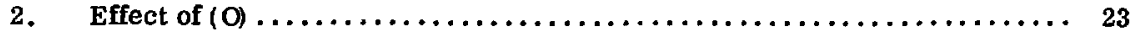

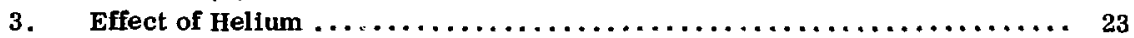

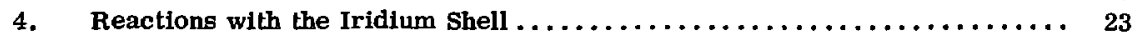

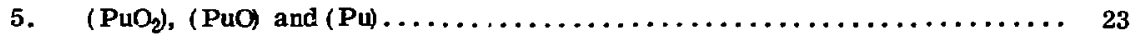

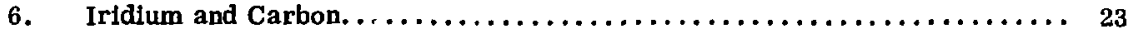

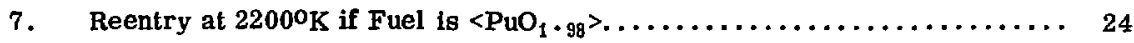

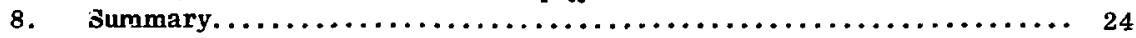

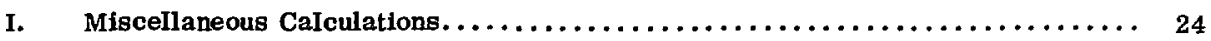

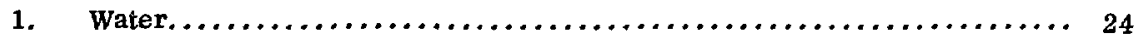

2. Carbon and Carbon Monoxide........................ 24

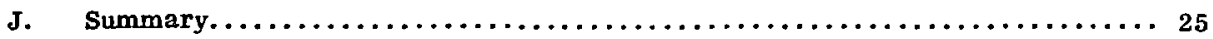

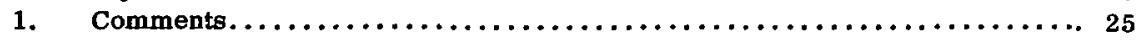

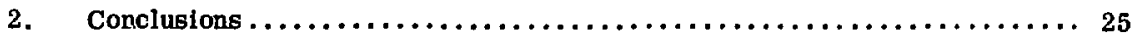

APPENDIX A: THERMODYNAMIC DATA FOR COMPONENTS OF FSA SYSTEMS . . . . . 29

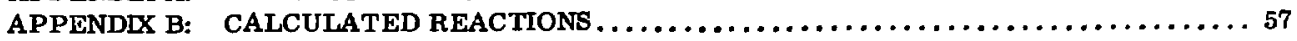
APPENDLX C: CALCULATIONS PERTAINING TO FSA SYSTEMS ................96 


\title{
THERMODYNAMIC ANALYSIS OF MHW SPACE ELECTRIC POWER GENERATOR
}

by

R. A. Kent

\begin{abstract}
A thermodynamic analysis has been made for the proposed Multihundred Watt (MHW) isotopic electric power heat source for space missions. The heat source consists of plutonium dioxide fuel spheres encapsulated in welded iridium shells that in turn are surrounded by graphite ablation shields. Published data for the component systems $\mathrm{Pu}-\mathrm{O}, \mathrm{Pu}-\mathrm{Ir}, \mathrm{Pu}-\mathrm{C}, \mathrm{Ir}-\mathrm{O}$ and $\mathrm{Ir}-\mathrm{C}$ have been reviewed and employed to calculate the thermochemical behavior during mission lifetime.
\end{abstract}

\section{INTRODUCTION}

The proposed Multihundred Watt (MHW) helipak heat source assembly (HSA) consists of 24 individual fuel Bphere assemblies (FSA) packaged in a $4 \times 6$ matrix. Each FSA consists of a 100 watt plutonium dioxide fuel sphere with a diameter oi 1.465 in. The fuel spheres are encapsulated in welded iridium post-impact containment shells 0.020 in. thick with an $0 . d$. of about 1.60 in. These irtdlum sheils are provided with two small vents (diam $=$ 0.002 in.) to allow for the release of helium gas generated by the fuel. The iridium shells are surrounded by $0.4-0.5$ in. thick graphite impact shells. Small gaps between the various FSA components are provided to allow for thermal expansion effecte.

The 24 FSA' 8 are mounted in a $4 \times 6$ matrix surrounded by graphlte and contained in a graphlte ablation shleld. The entire 2400 watt assembly is packaged in an irfdium outer can provided with a pressure rellef device to allow releane of bellum to outer space.

Various components of the heat source will operate at different temperatures throughout the inisgion lifetime.
The ambient surface temperature for an unclad fuel sphere is $400-500^{\circ} \mathrm{C}$. After encapsulation in the iridium the ambient surface temperature rises to $700-900^{\circ} \mathrm{C}$. The predicted operational temperature at the fuel-iridium interface will be $1350-1450^{\circ} \mathrm{C}$. Finally the system could be subjected to a $5 \mathrm{~min}$ thermal ramp to $1750-1900^{\circ} \mathrm{C}$ during reentry.

The systems of interest from the point of view of chemlcal and thermodynamic stability are: $\mathrm{Pu}-\mathrm{O}, \mathrm{Pu}-\mathrm{Ir}$, Pu-C, Ir-O and.Ir-C. This report consiste of three parts. The first is a review of published thermodynamic data for the systems of Interest. Thermodynamic data required for the calculations are listed for various temperatures in a series of tables in Appendix $\mathrm{A}$. The second part consists of a series of calculatlons pertaining to possible reactions between the fuel and the other components in the system. These calculations are summarized in a serles of tables in Appendix B. The last part of the report consista of a thermodynamic analysis for various temperatures of interest of the MHW heat source itself. 
Throughout the text and appendices the following symbols are employed: $<>$ for solids, () for gases and \{\} for liquids.

\section{SUMMARY OF PUBLISHED DATA \\ A. Plutonium}

1. Thermodynamic Functions. Thermodynamic functions for gaseous Pu are listed in Table A-1. These values, based on ideal gas behavior, were calculated by Feber and Herrick ${ }^{1}$ from published data for 293 spectroscopic levels. Unfortunately, accurate heat capacity data for condensed Pu do not exist, especially at high temperatures. Rand $^{2}$ has reviewed available literature data and lists recommended values for the heat capacity as a function of temperature. He also recommends values for $S_{298}^{0}$ and for the heat and entropy trrms associated with the various phase transitions. Rana's values, which correlate well with published vapor pressure data, were used to calculate the thermodynamic functions for $\langle\mathrm{Pu}\rangle$ and \{Pu\} listed in Table A-2.

2. Vapor Pressure Measurements. Phipps et al., employed Ta Knudsen ceilla 'n ? : sasure the vapor pressure of $\mathrm{Pu}$ over the range $1392-1793^{\circ} \mathrm{K}$. Mulford ${ }^{4}$ also employed Ta Knudsen cells in his target collection-type experiments over the range $1133-1792^{\circ} \mathrm{K}$. In addition, he contained liquid $\mathrm{Pu}$ in internal cups of $\mathrm{TaC}, \mathrm{ThO}_{2}$ and $\mathrm{MgO}$ without finding any significant differences in vapor pressures. Kent ${ }^{5}$ showed that $\{\mathrm{Pu}\}$ vaporizes predominately to the monomer in a mass spectrometric-Knudsen effusion study over the range $1426-1658^{\circ} \mathrm{K}$. In the latter study, $\{F u\}$ was contained in both W Knudsen cells and $\mathrm{ThO}_{2}$ inicrnal cups. The vapor pressure data from the three studies are in good agreement and were combined ${ }^{5}$ with the thermodynamic functions listed in Tables A-1 and A-2 to yield the thermodynamic values for the vaporization of Pu listed in Table A-3.

\section{B. Oxygen}

Thermodynamics functions for $(\mathrm{O})$ and $\left(\mathrm{O}_{2}\right)$ are taken from the JANAF Pables ${ }^{6}$ and are listed in Tables A-4 and A-5 reepectively.

\section{Plutonium Oxides}

\section{Thermodynamics Furctions for $\left\langle\mathrm{PuO}_{2}\right\rangle$. The} $\mathrm{Pu}-\mathrm{O}$ system has been studied extensively and excellent review papers pertaining to data published prior to 1966 have been published by Rand ${ }^{2}$, Mulford and Holley ${ }^{7}$, and Markir and Rand ${ }^{8}$.

For this work, the heat of formation for $\left\langle\mathrm{PuO}_{2}\right\rangle$ is taken to be $\Delta H_{f_{298}^{0}}^{0}=-252.35 \pm 0.17 \mathrm{kcal} / \mathrm{mole}{ }^{9}$. The heat capacity at $298^{\circ} \mathrm{K}$ is taken to be $16.4 \mathrm{eu}^{10,11}$.

The value for the absolute entropy at $298^{\circ} \mathrm{K}$ is somewhat uncertain. Sandenaw ${ }^{10}$ obtained a value of $16.3 \mathrm{eu}$, which is almost certainly too low. Westrum et al. ${ }^{12}$, estimated a higher value based on the measured entropies of $\left\langle\mathrm{NpO}_{2}\right\rangle,\left\langle\mathrm{ThO}_{2}\right\rangle$ and $\left\langle\mathrm{UO}_{2}\right\rangle$. Both $\left\langle\mathrm{NpO}_{2}\right\rangle$ and $\left\langle\mathrm{UO}_{2}\right\rangle$ ehow anomalies of magnetic origin near $25^{\circ} \mathrm{K}$, while $\left\langle\mathrm{ThO}_{2}\right\rangle$ does not. The authors suggest that the magnetic contribution to the entropy can be approximated by the spin-only contribution computed from the number of unpaired $5 f$ electrons in $\mathrm{Np}^{+4}$ and $\mathrm{U}^{+4}$. There are no unpaired electrons for $\mathrm{Th}^{+4}$, thus it is diamagnetic, shows no magnetin ordering, and the entropy of $\left\langle\mathrm{ThO}_{2}\right\rangle$ is purely lattice entropy. The observed excess entropy of $\left\langle\mathrm{NpO}_{2}\right\rangle$ and $\left\langle\mathrm{UO}_{2}\right\rangle$, over the lattice entropy (assumed the same as for $\left\langle\mathrm{ThO}_{2}\right\rangle$, is equal to $\mathrm{Rln}(2 S+1)+0.85$ where $S$ is the spin quantum number for the appropriate number of $5 f$ electrons, and 0.85 is a constant presumed to include any electronic entropy. The value estimated for $\left\langle\mathrm{PuO}_{2}\right\rangle$ is $\mathrm{S}_{298}^{0}=19.7 \mathrm{eu}$.

If the magnetic ordering does exist and Sandenaw falled to observe it because he did not attain low enough temperatures, one can add $\operatorname{RIn} 5=3.2$ to his value of 16.3 eu and obtain $S_{298}^{0}=19.5 \mathrm{eu}$, in good agreement with Westrum's estimated value. Accordingly, the value of $S_{298}^{0}$ for $\left\langle\mathrm{PuO}_{2}\right\rangle$ is taken to be $19.7 \mathrm{eu}$.

The heat content of $\left\langle\mathrm{PuO}_{2}\right\rangle$ has been mensured in the range $192-1400^{\circ} \mathrm{K}$ by $\mathrm{Kruger}$ and Savage ${ }^{13}$ and in the range $1500-2400^{\circ} \mathrm{K}$ by $\mathrm{Ogard}^{14}$. The agreement between the Lwo sets of data in the overlap region $1400-1500^{\circ} \mathrm{K}$ is excellant. The heat content term derived from Ogards data is

$$
\begin{aligned}
\mathrm{H}_{\mathrm{T}}^{0} & -\mathrm{H}_{29 \mathrm{~B}}^{0}=-6,360+18.0 \mathrm{~T},{ }^{0} \mathrm{~K}+1.95 \times 10^{-8} \mathrm{~T},{ }^{\circ} \mathrm{K} \\
& +2.46 \times 10^{5} / \mathrm{T}^{0} \mathrm{~K},(\mathrm{cal} / \mathrm{mole})
\end{aligned}
$$


from which one derives

$$
\begin{aligned}
& \text { and } \mathrm{C}_{\mathrm{p}}=18.0+3.9 \times 10^{-3} \mathrm{~T}-2.46 \times 10^{5} / \mathrm{T}^{2} \text {, (eu) } \\
& \mathrm{S}_{\mathrm{T}}^{0}-\mathrm{S}_{298}^{0}=18.0 \ln \mathrm{T} / 298+3.9 \times 10^{-3}(\mathrm{~T}-298) \\
& -1.23 \times 10^{5}\left(\mathrm{~T}^{2}-298^{2} / 298^{2} \mathrm{~T}^{2}\right) \text {, (eu). }
\end{aligned}
$$

Equations (1), (2) and (3), combined with the values $\Delta \mathrm{H}_{\mathrm{f}_{298}^{0}}^{0}=-252.35 \mathrm{kcal} / \mathrm{mnle}$ and $\mathrm{S}_{298}^{0}=19.7 \mathrm{eu}$, were used to calculate the thermodynamic functions for $\left\langle\mathrm{PuO}_{2}\right\rangle$ listed in Table $A-6$.

\section{Free Energy Values for $\left\langle\mathrm{PuO}_{2-\mathrm{X}}\right\rangle$ Species and} Partial Molar Free Energies for Orygen in $\left\langle\mathrm{PuO}_{2-\mathrm{X}}\right\rangle$ Species, Rand ${ }^{2}$, Markin and Rand ${ }^{8}$ and Ackermann, Faircloth and Rand ${ }^{15}$ have reviewed the thermodynamics pertaining to solid $\mathrm{Pu}-\mathrm{O}$ species ranging from $\left\langle\mathrm{PuO}_{2}\right\rangle$ to $\left\langle\mathrm{PuO}_{1} \cdot{ }_{5}\right\rangle$. In addition, Markin and Rand ${ }^{8}$ measured the oxygen potentials over the single phase oxides between $\left\langle\mathrm{PuO}_{\mathrm{j} \cdot 61}\right\rangle$ and $\left\langle\mathrm{PuO}_{2}\right\rangle$ in the range $950-1350^{\circ} \mathrm{K}$ using an EMF technique. Finally, Ackermann et al., have measured the vapor pressure above the solid substoichiometric dicxide phase $[\sim 1.6 \leq \mathrm{O} / \mathrm{Pu} \leq 2.07$ and combired the vapor pressure data with the oxygen potentials ${ }^{8}$ to yield recommended values for the standard free energies of formation for various $<\mathrm{PuO}_{2-\mathrm{x}}>$ compositions and for the partial molar free energies of atomic oxygen for these compositions.

Equations for the standard free energies of formation for varisus solid $\mathrm{Pu}-\mathrm{O}$ compositions and for the partial molar fres energies of atomic oxygen for these compositions are listed in Table $\mathrm{A}-7$.

Values for the free energy of formation for $\left\langle\mathrm{PuO}_{2}\right\rangle$, listed In Table A-6, and those calculated from the first equation listed in Table A-7, are compared in Table A-8. The agreement is excellent especially in the range 1000$2200^{\circ} \mathrm{K}$, the temperature range of interest for ${ }^{238} \mathrm{PuO}_{2}$ space power generators.

Therefore, the values given by the equations listed in Table A-7 are employed in the calculations that follow. It should be noted that these, values lead to a good correlation of the varlous sets of vapor pressure data to be discussed below.
3. Free Energies of Formation for $(\mathrm{PuO})$ and $\left(\mathrm{PuO}_{2}\right)$. Ackermann et al. ${ }^{15}$, recommend the following expressions for the free energies of formation for ( $\mathrm{PuO})$ and $\left(\mathrm{PuO}_{2}\right)$ : For (PuO)

$$
\begin{aligned}
& \Delta \mathrm{G}_{\mathrm{f}}=-29,000-12.1 \mathrm{~T},{ }^{\circ} \mathrm{K}(\mathrm{cal} / \mathrm{mole}),(1600- \\
& 2200^{\circ} \mathrm{K}
\end{aligned}
$$

and for $\left(\mathrm{PuO}_{2}\right)$

$$
\begin{aligned}
& \Delta \mathrm{G}_{\mathrm{f}}=-113,100+4.35 \mathrm{~T},{ }^{\mathrm{C}} \mathrm{K}(\mathrm{cal} / \mathrm{mole}),(1600- \\
& \left.2200^{\circ} \mathrm{K}\right) .
\end{aligned}
$$

The values given by Eqs. (4) and (5) lead to a good correlation of the published vapor pressure data. Thus, these values are used in the calculations that follow.

4. Calculated Vapor Pressure Values Above Various $\left.<\mathrm{PuO}_{2-\mathrm{x}}\right\rangle$ Compositions. Solid plutonium dioxide vaporizes in a complex manner to yield $\left\langle\mathrm{PuO}_{2}-\mathrm{x}\right\rangle,(\mathrm{Pu}),(\mathrm{PuO})$, $\left(\mathrm{PuO}_{2}\right)$ and $\left(\mathrm{O}_{2}\right)$. This section lists calculated partial pressure values for $(\mathrm{Pu}),(\mathrm{PuO}),\left(\mathrm{PuO}_{2}\right)$ and $\left(\mathrm{O}_{2}\right)$ above various $\left\langle\mathrm{PuO}_{2}-\mathrm{x}\right\rangle$ compositions.

\section{a. (O) Partial Pressures. Partial pressure} values for $\left(\mathrm{O}_{2}\right)$ were obtained from the relationship

$$
(\mathrm{O})=1 / 2\left(\mathrm{O}_{2}\right) \text {. }
$$

For Eq. (6) the free energy is given by

$$
\begin{aligned}
\Delta \mathbf{G} & =-\mathbf{R} \ln K=-R T \ln P_{\mathrm{O}_{2}}^{\frac{1}{2}} / \mathbf{P}_{\mathrm{O}} \\
& =-(\mathrm{R} T / 2) \ln \mathbf{P}_{\mathrm{O}_{2}}+{\overline{\Delta G_{0}}}
\end{aligned}
$$

Finally

$$
\ln P_{O_{2}}=-(2 / R T)\left[-\Delta G_{f}(O)-\overline{\Delta G_{0}}\right]
$$

Values for $\Delta G_{f}(O)$ are listed in Table $A-4$. Values for $\overline{\Delta G_{0}}$ were obtained from the equations listed in Table $A-7$.

b. (PuO) Partial Pressures. Partial pressure values for ( $\mathrm{PuO}$ ) were obtained from the relationship

$$
\left\langle\mathrm{PuO}_{2-\mathrm{x}}\right\rangle=(\mathrm{PuO})+(1-\mathrm{x})(\mathrm{O}) \text {. }
$$

For Eq. (9) the free energy is given by

$$
\begin{aligned}
\Delta G & =\Delta G_{f}\left(P(O)+(1-x) \Delta G_{f}(O)-\Delta G_{f}<P u O_{2-x}>\right. \\
& =-R T \ln K=-R T\left[\ln P_{P, O}+(1-x) \ln P_{O}\right]
\end{aligned}
$$

Values for $\Delta G_{f}(O)$ and $\Delta G_{f}<P u O_{2}-x>$ are listed in Tables $A-4$ and $A-7$, respectively. Values for $\Delta G_{f}(P u O)$ were calculated using Eq. (4). Values for $P_{O}$ were obtained from a combination of Eqs. (7) and (8).

\section{c. Pu) Partial Pressures. Partial pressure}

values for ( $P u$ ) were obtained from the relationship

$$
\left\langle\mathrm{PuO}_{2-\mathrm{X}}\right\rangle=(\mathrm{Pu})+(2-\mathrm{x})(\mathrm{O})
$$


For Eq. (11) the free energy is given by

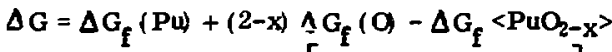

$$
\begin{aligned}
& =-R T \ln K=-R T\left[\ln P_{P_{u}}+(2-x) \ln P_{O}\right]
\end{aligned}
$$

Values for $\Delta G_{f}(P w)$ are listed in Table $A-3$.

\section{d. (PuO) Partial Pressures. It was noted}

above that $\left\langle\mathrm{PuO}_{2}-\mathrm{x}\right\rangle$ compositions vaporize in a complex manner to yleld (Pu), (PuO), $\left(\mathrm{PuO}_{2}\right)$ and $\left(\mathrm{O}_{2}\right)$. The simplest relationship from which values for the partial pressure of ( $\left.\mathrm{PuO}_{2}\right)$ may be calculated is

$$
\left\langle\mathrm{PuO}_{2-\mathrm{x}}\right\rangle+\mathrm{x}(\mathrm{O})=\left(\mathrm{PuO}_{2}\right) \text {. }
$$

For Eg. (13) the free energy is given by

$$
\begin{aligned}
\Delta G & =\Delta G_{f}\left(P u O_{2}\right)-\Delta G_{\mathrm{f}}\left\langle P_{u O_{2}-x}\right\rangle-x \Delta G_{f}(O) \\
& =-R T \ln K=-R T\left[\ln P_{P_{L O}}+x \ln P_{O}\right]
\end{aligned}
$$

Values for $\Delta \mathrm{G}_{\mathrm{f}}\left(\mathrm{PuO}_{2}\right)$ were calculated from $\mathrm{Eq}$. (5).

e. Congruency of Vaporization. A combination

of Eq5. (6), (9), (11) and (13) yields for the vaporization of $\left\langle\vec{y} u O_{2}-x\right\rangle$ the overall relationship

$$
\begin{gathered}
\left.<\mathrm{PuO}_{2-\mathrm{x}}\right\rangle=1 / 3\left(\mathrm{PuO}_{2}\right)+1 / 3(\mathrm{PuO})+1 / 3(\mathrm{Pu})+ \\
(1-\mathrm{x} / 2)\left(\mathrm{O}_{2}\right)
\end{gathered}
$$

Equilibrium partial pressure values of ( $\left.\mathrm{PuO}_{2}\right),(\mathrm{PuO}),(\mathrm{Pu})$ and $\left(O_{2}\right)$ calculated at difierent temperatures for varlous $<\mathrm{PuO}_{7-\mathrm{x}}>$ compositions are listed in Tables A-9 to A-19. These values indicate that plutonium dioxide vaporizes congruently, that is, at a given temperature, the overall compasition of the condensed and gaseous phases is the oame. The exact composition of the congruent phase varies with temperature, the $\mathrm{O} / \mathrm{Pu}$ ratio ranging from near 2.0 toward 1.61 as the temperature is increased. Values for the confruently vaporizing composition are listed as a function of temperature in Table A-20. Values are listed In Table A-20 both for closed systems (FSA's) and for open systems (Knudsen cells), where the more rapld effusion of lighter species such as $\left(O_{2}\right)$ is taken into account.

Values for the partial pressures above different compositions are shown for 1440 and $1827^{\circ} \mathrm{C}$ in Figs. 1 and 2.

\section{Eyperimental Vapor Pressures. All of the ex-} perimental data Indicate that plutonium oxide vaporizes congruently as $\left\langle\mathrm{PuO}_{2-\mathrm{x}}\right\rangle$ between $\mathrm{O} / \mathrm{Pu}$ ratios from 2.0 to about 1.6. In the two phase region $\left\langle\mathrm{PuO}_{1} \cdot 61-\mathrm{PuO}_{1} \cdot 50\right\rangle$ the vaporization is invariant. a. $\left\langle\mathrm{PuO}_{2}-\mathrm{x}^{\rangle}\right.$. A number of workers have measured the vapor pressure above $\left\langle\mathrm{PuO}_{2}-\mathrm{x}\right\rangle$ compositions and several of the more recent studies will be discussed. Ackermann et al., employed $W$ and Re Knudsen cells cver the range $1650-2070^{\circ} \mathrm{K}$, collecting a known fracticn of the effusate on Pt targets. They assumed the vapor to consist primarily of $\left(\mathrm{PuO}_{2}\right)$ and obtained for the effective pressure the equation

$$
\log P_{E}(\mathrm{~atm})=7.50-29,260 / \mathrm{T},{ }^{\circ} \mathrm{K}
$$

When $\left\langle\mathrm{PuO}_{2}\right\rangle$ was first heated in the $\mathrm{W}$ and Re cells, reactions producing gaseous $W$ and Re oxides were noted. No further $W$ or Re reactions were observed even at higher temperatures. It was concluded that $2 s\left\langle\mathrm{PuO}_{2}\right\rangle$ is reduced to $\left\langle\mathrm{PuO}_{2}-\mathrm{x}\right\rangle$ the oxygen activity drops to a level too luw to produce significant reaction with the $W$ or Re. The composition of the residue was estimated to be $\left\langle\mathrm{PuO}_{1} \cdot 9_{2}\right\rangle$. Ohse and Ciani ${ }^{16}$ determined that the congruently vaporking composition ranges from $\left\langle\mathrm{PuO}_{1} \cdot{ }_{89}\right\rangle$ at $1800^{\circ} \mathrm{K}$ to $\left\langle\mathrm{PuO}_{1} \cdot{ }_{86}\right\rangle$ at $2000^{\circ} \mathrm{K}$ and to $\left\langle\mathrm{PuO}_{1} \cdot 84\right\rangle$ at $2200^{\circ} \mathrm{K}$.

These values are in excellent agreement with the calculated values listed in Table $A-20$. In addition, their data show that the lower phase boundary of the $\left\langle\mathrm{PuO}_{2}-\mathrm{x}\right\rangle$ phase is at $\left\langle\mathrm{PuO}_{1 \cdot 61}\right\rangle$ up to $2200^{\circ} \mathrm{K}$.

Messier ${ }^{17}$ employed $W$ Knudsen cells and an automatic-recording semimicro balanee to measure the vapor pressure in the range $2070-2380^{\circ} \mathrm{K}$. Again, assuming the vapor to be ( $\left.\mathrm{PuO}_{2}\right)$, be obtained for the effective pressure the equation

$$
\log P_{E}(\mathrm{~atm})=8.38-30,970 / \mathrm{T},{ }_{\mathrm{K}}^{\mathrm{K}} \text {. }
$$

The plutorisum dioxide was reduced prior to the vapor pressure experiment in order that the congruent compost Hon might be attained more quickly. During the experiment the sample composition changed from $\left\langle\mathrm{PuO}_{1} \cdot 89\right\rangle$ to $\left\langle\mathrm{PuO}_{1 \cdot 81}\right\rangle$. He also noticed a reaction between the $W$ cell and $\left\langle\mathrm{PuO}_{2-\mathrm{x}}\right\rangle$ to produce gaseous $\mathrm{W}$ oxides. However the extent of the reaction was too small to appreciably affect the vapor pressure calculations.

Messier noted that the phase boundary for the $\left\langle\mathrm{PuO}_{2}-\mathrm{X}\right\rangle$ phase is between $\left\langle\mathrm{PuO}_{1} \cdot{ }_{56}\right\rangle$ and $\left\langle\mathrm{PuO}_{1} \cdot{ }_{62}\right\rangle$ up to $2380^{\circ} \mathrm{K}$. Thus, it is concluded that the lower phase bounary for $\left\langle\mathrm{PuO}_{2-\mathrm{x}}\right\rangle$ is $\left\langle\mathrm{PuO}_{1} \cdot \mathrm{G1}_{1}\right\rangle$ up to the liquidus. 
Battles et al. 18 employed a mass spectrometer to determine the partial pressures of $(\mathrm{PuO})$ and $\left(\mathrm{PuO}_{2}\right)$ above $<\mathrm{PuO}_{2-\mathrm{x}}>$. They employed $\mathrm{W}$ and Re Knudsen cells and also observed the initial presence of gaseous $W$ and $R e$ oxides. These species disappeared as the plutonium dioxide was redused. They also employed Ir Knudsen cells and observed no gaseous $\mathrm{Ir}-\mathrm{O}$ species, indicating little or no reaction between $\langle\mathrm{Ir}\rangle$ and $\left\langle\mathrm{PuO}_{2}\right\rangle$.

The partial pressure values for $(\mathrm{PuO})$ and $(\mathrm{PuO})$ are given by the equations

and

$$
\log \mathrm{P}_{\mathrm{PuO}}{ }^{(\mathrm{atm})}=6.71-27,810 / \mathrm{T},{ }_{\mathrm{K}}^{\mathrm{O}}
$$

$$
\log \mathrm{P}_{\mathrm{PuO}_{2}}(\mathrm{~atm})=7.75-30,330 / \mathrm{T},{ }^{\circ} \mathrm{K}
$$

Only trace quantities of ( $\mathrm{Pu}$ ) were observed, in agreement with the calculated values listed in Tables A-9 to A-19. The residues were found to be approximately $\left\langle\mathrm{PuO}_{1} \cdot{ }_{89}\right\rangle$ by analysis.

The mass spectrometric data may be compared to the data of Ackermann et al. , and Messier by calculating a $P_{E}$ value from the mass spectrometric data via the equation

$$
\mathrm{P}_{\mathrm{E}}\left(\text { atrm) }=\mathrm{P}_{\mathrm{PuO}_{2}}+\left({ }^{\mathrm{M}} \mathrm{PuO} / \mathrm{M}_{\mathrm{PuO}_{2}}\right)^{1 / 2} \mathrm{P}_{\mathrm{PuO}}\right.
$$

The pressures are in atmospheres and $\mathrm{M}$ is the molecular weight of the effusing species.

Kent ${ }^{19}$ employed $W$ Knudsen cells and a mass spectrometer to measure the partial pressures of ( $\mathrm{PuO}$ ) and $\left(\mathrm{PuO}_{2}\right)$ over the range $2000 \cdots 2200^{\circ} \mathrm{K}$. Agaiu, small amounts of gaseous $\mathrm{W}$ oxides were observed initially. The partial pressure values are given by the equation

$$
\log \mathrm{P}_{\mathrm{PuO}}{ }^{(\mathrm{atm})}=6.81-28,257 / \mathrm{T},{ }^{\mathrm{O}} \mathrm{K}
$$

and

$$
\log \mathrm{P}_{\mathrm{PuO}_{2}}(\mathrm{~atm})=7.69-29,928 / \mathrm{T},{ }^{\circ} \mathrm{K}
$$

Values of $P_{E}$ were calculated using $\mathrm{Eq}$. (20) in order to compare the mass spectrometrics results with other data. The residue stolchiometry was $\left\langle\mathrm{PuO}_{1} \cdot{ }_{83}\right\rangle$.

Kent also determined partial pressure values for ( $\mathrm{PuO})$ and $\left(\mathrm{PuO}_{2}\right)$ above a sample that initially had the stoichiometry $\left\langle\mathrm{Pu}_{0.45} \mathrm{Th}_{0.55} \mathrm{O}_{2.0}\right\rangle$. The temperature range covered was $2000-2230^{\circ} \mathrm{K}$. The partial pressure values are given by the equations

$$
\log P_{\mathrm{PuO}}{ }^{(\mathrm{atm})}=6.96-28,476 / \mathrm{T},{ }^{\circ} \mathrm{K}
$$

$$
\log \mathrm{P}_{\mathrm{PuO}_{2}}(\mathrm{~atm})=6.64-28,229 / \mathrm{T},{ }^{\mathrm{o}} \mathrm{K} \text {. }
$$

No gaseous Th-O species were observed. The vapor pressure data suggest that when the solid solution is heated, the $\mathrm{ThO}_{2}$ remains inert, and all of the sample reduction occurs with the plutonium oxide.

The values of $P_{E}$ calculated from the data of the various workers are compared in Table A-21. The heat and entropy of vaporization terms obtained by the various workers are in reasonably good agreement except for the results of Messier. The values for $P_{E}$ are in fair agreement.

One should note that each of these workers operated in a slightly different temperature range and obtained data at different average temperatures. When this is taken into account together with the fact that the stoichiometry of the congruently vaporizing composition changes with temperature, improved agreement is noted between the various sets of data. While the heat terms obtained from the slopes differ, the agreement in the pressure values indicates that the third law heats would be in good agreement.

The caiculated partial pressure values, given for various stoichiometries in Tables A-9 to A-19, may be employed to calculate values for $P_{E}$ according to the equation

$$
\begin{gathered}
P_{E}(\mathrm{~atm})=\mathrm{P}_{\mathrm{PuO}_{2}}+\left(\mathrm{M}_{\mathrm{PuO}} / \mathrm{M}_{\mathrm{PuO}_{2}}\right)^{1 / 2} \mathrm{P}_{\mathrm{PuO}^{+}} \\
\left(\mathrm{M}_{\mathrm{Pu}} / \mathrm{M}_{\mathrm{PuO}_{2}}\right) \mathrm{P}_{\mathrm{Pu}}
\end{gathered}
$$

The experimental $P_{E}$ values are compared with the calculated $P_{E}$ values in 'Table A-22. The stoichiometries listed are those calculated for the experimental temperatures. The agreement for each set of data is reasonably good. The calculated $\mathrm{O} / \mathrm{Pu}$ ratios are generally in agreement with those determined experimentally. The accuracy est imated for the calculated $\mathrm{O} / \mathrm{Pu}$ ratios is \pm 0.02 . This is the same accuracy that is routinely obtained by chemical analyses of experimental samples.

\section{b. $\left\langle\mathrm{PuO}_{1.61}-\mathrm{PuO}_{1 \cdot 50}\right\rangle$. A number of work-} ers have determined vapor pressures above the two-phase region $\left\langle\mathrm{PuO}_{1} \cdot 61-\mathrm{P}_{10} \mathrm{O}_{1} \cdot 50\right\rangle$. Phipps et al. ${ }^{20}$ employed a target-collection technique and beated plutonium dioxide in a Ta Knudsen cell over the range $1600-2100^{\circ} \mathrm{K}$.

and 
Their intent was to determine the vapor pressure above $\left\langle\mathrm{PuO}_{2}\right\rangle$, however, the Ta cell reduced the sample and they actually determined the pressure above $\left\langle\mathrm{PuO}_{1} \cdot{ }_{61}\right.$ $\mathrm{FuO}_{1} \cdot{ }_{50}>$. Assuming the vapor to consist of (PuO), the value of $P_{E}$ calculated from their data is given by the equation

$$
\log P_{E}\left(\text { at m) }=8.13-27,910 / T,{ }^{\circ} \mathrm{K} .\right.
$$

Ackermann et al. ${ }^{15}$, deliberately reduced $\left\langle\mathrm{PuO}_{2}\right\rangle$ to $\left\langle\mathrm{PuO}_{1} \cdot \mathrm{G1}_{1}-\mathrm{PuO}_{1} \cdot{ }_{50}\right\rangle$ by using a Ta Knudsen cell over the range $1650-2100^{\circ} \mathrm{K}$. They assumed the vapor to consist of (PuO) and obtained for $P_{E}$ the equation

$$
\log P_{\mathrm{E}}(\mathrm{atm})=8.09-27800 / \mathrm{T},{ }^{\circ} \mathrm{K} \text {. }
$$

They estimated the residue stoichiometry to be $\left\langle\mathrm{PuO}_{1} \cdot{ }_{52}\right\rangle$.

Battles et al., employed a mass spectrometer to determine the partial pressures of ( $\mathrm{Pu}$, ( $\mathrm{PuO}$ ) and $\left(\mathrm{PuO}_{2}\right)$ over the range $1660-2150^{\circ} \mathrm{K}$. The sample was reduced to $\left.<\mathrm{PuO}_{1} \cdot{ }_{54}\right\rangle$ prior to the vapor pressure measurements. They used $W$ and Re Knudsen cells. The values for the partial pressures are

$$
\log P_{\text {PuO }}(\mathrm{atm})=7.10-25,806 / \mathrm{T}^{\circ} \mathrm{K}
$$

and

$$
\log \mathrm{P}_{\mathrm{PuO}_{2}}(\mathrm{~atm})=5.69-27,575 / \mathrm{T},{ }^{\circ} \mathrm{K}
$$

and for ( $P$ ù

$$
\log \mathrm{P}_{\mathrm{Pu}}(\mathrm{atm})=5.27-24,090 / \mathrm{T},{ }^{\circ} \mathrm{K} \text {. }
$$

The partial pressure data were used to calculate values of $P_{E}$, based on (PuO) as the effusing species, from the equation

$$
\begin{aligned}
& \left.\mathbf{P}_{\mathbf{E}}(\mathrm{atm})=\mathbf{P}_{\mathrm{PuO}}+i \mathrm{M}_{\mathrm{PuO}} / \mathrm{M}_{\mathrm{PuO}^{\prime}}\right)^{1 / 2} \mathbf{P}_{\mathrm{PuO}_{2}}+ \\
& \left(\mathrm{M}_{\mathrm{Pu}} / \mathrm{M}_{\mathrm{PuO}}\right)^{1 / 2} \mathrm{P}_{\mathrm{Pu}} \text {. }
\end{aligned}
$$

Kent ${ }^{19}$ used a mass spectrometer and Ta Knudsen cells over the range $1870-1960^{\circ} \mathrm{K}$ to determine the partial pressures above a sample that had an initial stoichiometry oi $\left\langle\mathrm{Pu}_{0.9} \mathrm{Th}_{0.1} \mathrm{O}_{2} \cdot \mathrm{P}\right\rangle$. No gaseous $\mathrm{Th}-\mathrm{O}$ species were observed. Values for $P_{E}$, based on (PuO) as the effusing species, were calculated using Eq.(31).

The vapor pressure data obtained by the various workers are compared in Table A-23. With the exception of the heat and entropy terms obtained by Battles et al. , the agreement is excellant. The partial pressure values calculated for the two-phase region $\left\langle\mathrm{PuO}_{1 \cdot 61}-\mathrm{PuO}_{1} \cdot{ }_{60}\right\rangle$ (Table A-19), were used to calculate $P_{E}$ values according to Eq. (31).
These calculated $P_{E}$ values are compared to the experimental values in Table A-24.

6. Summary. It is obvious that more experimental data are required for the PtrO system: (1) Extended mass spectrometric studies should be performed to deter mine more exactly the relative partial pressure values above various compositions, (2) The kinetics of the reducti on of $\left\langle\mathrm{PuO}_{2} \cdot 00\right.$ to $\left\langle\mathrm{PuO}_{2}-\mathrm{x}\right\rangle$ should be determined and (3) The data on oxygen partial molar free energies should be extended above $2000^{\circ} \mathrm{K}$. However, the agreement between the calculated vapor pressure values listed in Tables A-9 to A-19 and the experimental values is reasonably good. Therefore, the calculated values listed ln Tables A-9 to A-19 can be used to perform an adequate thermodynamic analysis for proposed space isotopic electric power generator systems.

\section{Carbon}

Graphite vaporizes to $(C),\left(C_{2}\right),\left(C_{3}\right) ;\left(C_{4}\right)$ and $\left(C_{5}\right)$. Thermodynamic functions for solid graphite are taken from the JANAF tables $^{6}$ and are listed in Table A-25. Thermodynemic functions for $(C),\left(C_{2}\right)$ and $\left(C_{3}\right)$ are also taken from the JANAF tables and are listed in Tables A-26, A-27, and A-28, respectively. Functions for $\left(C_{\downarrow}\right)$ and $\left(C_{5}\right)$ are not isted as the vapor pressures of these species above graphite below $2400^{\circ} \mathrm{K}$ are too low to affect the following calculations.

\section{E. Iridium}

The melting point of Ir metal, $2447^{\circ} \mathrm{C}$, is used as a secondary reference point for the International Practical Temperature Scale of $1968^{21}$. Paule and Margrave ${ }^{22}$, using a Langmuir Free-Evaporation technique, determined the vapor pressure of Ir metal over the range 2140$2480^{\circ} \mathrm{K}$ and obtained

$$
\log P_{I r}(\text { atm })=7.24-33,680 / T,{ }^{\circ} K \text {. }
$$

Thermodynamic functions for 〈Ir $\rangle$ are taken from stull and Sinke ${ }^{23}$ and are listed in Table A-29. They also list values for (Ir), based on ideal gas calculations. These values for (Ir), however, when combined with the values for < Ir> yield iridium vapor pressures that are too high when compared to the experimental data of Paule and Margrave. For this work, the vapor pressures of iridim are calculated from Eq. (32). 


\section{F. Iridium - Carbon Sustem}

A number of workers have Investigoted the $\mathrm{If}-\mathrm{C}$ syotem. The results of these studies are in good agreement and indicate that the solubility of $\mathrm{C}$ in Ir is low and that Ir and $C$ do not form a cumpound below $2400^{\circ} K$. However, Ir and $\mathrm{C}$ form a eutectle that melts about $150^{\circ} \mathrm{C}$ below the melting point of <Ir>.

Nadler and Kempter ${ }^{24}$ report an Ir-C cutectic to bo at $2296 \pm 16^{\circ} \mathrm{C}$. They also report that the alloy Ir-30Rh forms a eutectic with caribon at $1932 \pm 17^{\circ} \mathrm{C}$.

Lowell et al. 25 employed $x$-ray diffraction techniques to determine whether an Ir-C compound formed. They used two types of samples, 0.010 in. dian In wire coated with a graphite slurry, and 0.025 in. djam graphite rods coated with a slurry of Ir pouder. Both types of samples were heated over the range $800-3000^{\circ} \mathrm{C}$ and $\mathrm{x}$-ray diffraction patterns were obtained at $100^{\circ}$ intervals. In all cases, these patterns indicated the presence of only $<$ Ir $>$ and $<C>$. Thus, they concludad that no compound was formed.

Harmon $^{26}$ employed DTA and PIranl techniques and found the Ir-C eutectic crmposition to be $6.5 \mathrm{at}$. F $\mathrm{C}$ at $2302 \pm 15^{\circ} \mathrm{C}$. Harmon concluded that the Ir-C phase diauram is a simple eutectic type and that the solubility of $\mathrm{C}$ in Ir 18 low. He further found that the presence of a amall amount of Si impurity, 1 wt. $\%$, lowered the eutectlc melting temperature to about $2150^{\circ} \mathrm{C}$.

Reavis ${ }^{27}$ employed DTA techniques and determined the Ir-C eutectic point to be at $2296 \pm 20^{\circ} \mathrm{C}$.

Arnault and McLellan ${ }^{28}$ have determined the solubllity of $\mathrm{C}$ in Ir to be lov: over the range $820-1260^{\circ} \mathrm{C}$. In agreement with the data from the other studies. Values for the solubility of $C$ In Ir, calculated from these data, are listed in Table $\mathbf{A - 3 0}$.

\section{G. IrIdium - Oxygen System}

1. Solid Oxides. The only stable solid iridium oxide appears to be $\left\langle\mathrm{IrO}_{2}-\mathrm{x}\right\rangle$ where $\mathrm{x}$ varjes from about 0 to 0.5 Cordfunke and Meyer ${ }^{29}$ measured the dissoclation pres sure of $\left(\mathrm{O}_{2}\right)$ above $\left\langle\mathrm{IrO}_{2}\right\rangle$ and concluded that, above $800^{\circ} \mathrm{C}$, $<\mathrm{IrO}_{2}$ > vaporizes according to the reaction

$$
\left\langle\mathrm{IrO}_{2}\right\rangle=\left\langle\mathrm{IrO}_{2-\mathrm{X}}\right\rangle+\mathrm{x} / 2\left(\mathrm{O}_{2}\right) \text {. }
$$

They elaim that the reduced oxtde vartes from $<\mathrm{IrO}_{1} \cdot y^{\prime}=$ at $925^{\circ} \mathrm{C}$, to $\left\langle\operatorname{IrO}, \mathrm{t} 0^{\circ}\right.$ at $1050^{\circ} \mathrm{C}$. These authors pive for the $\left(\mathrm{O}_{2}\right)$ prossurc above the reduced solfd atro, $\mathrm{x}^{3}$ $\log P_{O_{2}}$ (2tm) $=5.606-11.750 / T .{ }^{n} x$

and above the stotchlometr. Jxide <irOs:

$$
\log \mathrm{P}_{\mathrm{C}_{2}} \text { (atm) }=9.503 \mathrm{~s}-12, \text { BgG/T. } \mathrm{K} \text {. }
$$

Equation (34) leads to an oxygen dissoclation pressure of 1 atre at $1062^{\circ} \mathrm{C}$. From thetr data, Cortfunke and Mejer sotain $\Delta H_{f_{2 x}}^{0},-64.0 \mathrm{kcal} / \mathrm{mole}$ for $<1 \mathrm{rO} \mathrm{O}_{3}=$

Schifer and fleitiand ${ }^{30}$ measured the $\left(\mathrm{O}_{2}\right)$ dfssociation pressure abote $\left\langle 1 \mathrm{Ir}+\left\langle 15 \mathrm{O}_{3}\right\rangle\right.$ and obtaincd

$\log \mathrm{PO}_{\mathrm{O}_{2}}(\mathrm{~atm})=4.437-11,319 / \mathrm{T} .^{\circ} \mathrm{K}+1.7 \mathrm{~g} 6 \mathrm{log} \mathrm{T}$

$-1.3965 \times 10^{-8} \mathrm{~T}-0.0407 \times 10^{3} / \mathrm{T}^{2}$.

Equation (3G) leads to an $(0)$ pressure of 1 atm at $2124^{\circ} \mathrm{C}$ From theft data they obtain $A H_{t_{24}}^{0}=-52.4 \mathrm{kcal} / \mathrm{mole}$ for $<\mathrm{IrO}_{2}$ ?.

Sore recently. Bcll et al.". have detarmined the $\left(O_{5}\right)$ dissociation pressure to be $1 \mathrm{~atm}$ at $1105^{\circ} \mathrm{C}$. Further. they claim that the composition of $\left\langle\mathrm{lr}_{2}>\right.$ deviates tory litule from atoichiometry in the range $800-2050^{\circ} \mathrm{C}$ and that $<\mathrm{IrO}_{2}>$ decomposes according to the equation

$$
\left\langle I r O_{2}\right\rangle=\langle I r\rangle+\left(O_{2}\right) \text {. }
$$

From their dath, they oblain $\Delta H_{I_{24}}^{0}=-57.4 \mathrm{kcal} / \mathrm{molo}$ and $\Delta S_{f_{2 s 0}^{0}}^{0}=-43.8 \mathrm{cu}$. for $\langle\mathrm{IrO}\rangle$.

Obvioubly, further study is required. The one conclustion that seems certain is that $<I \mathrm{IO}_{2}>$ decomposes when heated and the $\left(\mathrm{O}_{2}\right)$ pressure reaches $2 \mathrm{~atm}$ at aboul $1100^{\circ} \mathrm{C}$.

2. Gageous Oxides. A number of workers have studied the formation of gaseous Iridium oxides, the most definldve study being that of Norman, et $\mathrm{al}^{32}$ They employed a mass spectrometer, over the range $1830-2020^{\circ} \mathrm{K}$ to determine the gases formed when $\left(O_{2}\right)$ was introduced Into an Ir Knudsen cell at elevared temperatures. The gases formed were (IrO), (IrO) and (IrO) ). At $2033^{\circ} \mathrm{K}$, with an $\left(\mathrm{O}_{2}\right)$ preasure of $4.3 \times 10^{-4} \mathrm{~atm}$, they determined the (IrO) pressure to be $1.9 \times 10^{-1}$ atm and the (IrO) pressure to be $3.1 \times 10^{-9} \mathrm{~atm}$. The $(\mathrm{IrO})$ pressure at $2033^{\circ} \mathrm{K}$ was about $1 / 50$ that of (1rO, ). They found that (IrO) and (IrO) formed according to the equations:

$$
\langle I r\rangle+\left(O_{2}\right)=\left(I r O_{2}\right)
$$


and

$4 x \div 1.5(0)=\left(1+0_{2}\right)$.

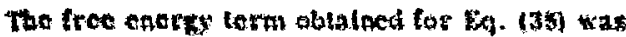

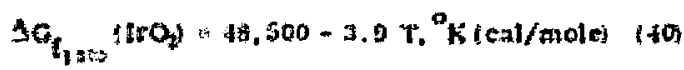
while that for Eq. (59) was

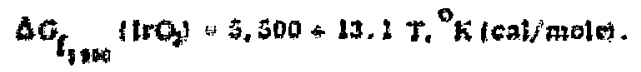

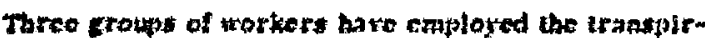

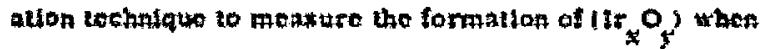
thay pasted toj al prestures tandax from 0.03 to 1 atm. ares centr.

Sehiffer and Heteland ${ }^{30}$ assumed that in the rake 1000-1200 $\mathrm{C}$ the tapor species was (120) formed aceordIft to 19. 159. Frow thetr data, one oblalns

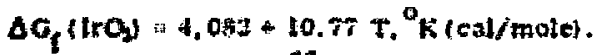

Cordfunke and Megar ${ }^{33}$, trotking in the range 1170 $1460^{\circ} \mathrm{C}$, oblatined

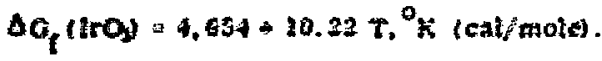

These aubors also measured the formation of (tr $x^{0}$ )

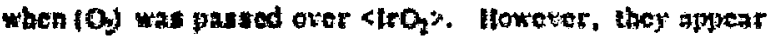
to bave iznored the taptation in $4 \mathrm{IrO}>$ stolchl smetry which they had dotermined by ioctr own dissectalion pre\$\$4to studies 29 .

Alcock and trooper 3 , working in the rangt: 20 $1400^{\circ} \mathrm{C}$, oblained

$$
\Delta G_{f}\left(5+O_{1}\right)=4.146+10.8 T .{ }^{\circ} \mathrm{K}(\mathrm{cal} / \mathrm{molcl} \text {. }
$$

Howevar, thoy sugested that the gateous spectes lingt have been $\left(\mathrm{ln}_{2} \mathrm{O}_{2}\right)$.

Tentatue conftrmation of thlo yosalbitty was protlded by the mass spectrometric atudy of kurlakowe, Neat and Mancrave 53 . At $900^{\circ} \mathrm{C}$ and 2 atm $(O)$ pressure. these authors oberved exentite transfor of if via cascous oxddes. Whan thege speeles wore introduced into the mase spectrometer, the lon $1 \mathrm{r}_{2} \mathrm{O}_{2}^{*}$, prosumably a trasment from $\left(\mathrm{Ir}_{2} \mathrm{O}_{2}\right)$, was obaerved. These aubors also noted that the iridlum oxide species elfacked the $\mathrm{SIO}_{3}$ molecular leak assembly.

The free energy of formation terms for the formatlon of (IrO), Eqs. (42), (43) and (44), oblained from the transplration studies are in good agreemont. However, these date ere extrapolated to $1900^{\circ} \mathrm{K}$, they yteld an average value for the free energy of formation for (IrO) of $24.43 \mathrm{kcal} / \mathrm{mole}$ in very poor agreement with the value giten by Eq. (at) obtained in the mats apectrometrif

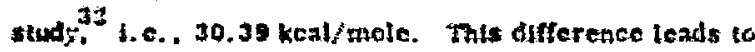
a Ector of atrout 5 in the ealculated $\left(\mathrm{tro}_{2}\right)$ pressure at $1900^{\circ} \mathrm{K}$. Thus. one must concitude that (l) the nasss sjeccrometrle dafa ate wrong, (d) the reaction mechantem at the terajorature of the transplation experiments is more complex that previounty reallyed and perbans intoltes the formation of (fr, $\mathrm{O}_{3}$ ) ar $(3)$ there is a charafe ta the axIdation mechanixa ff going from the temperature range of the eranspitation studies to that of the mass spectromeIrfe sludies. The second and thind conclustons are believed more llkets fa rlex of the results obtatned th the finclle siadies deseribed below.

In summaty, therc arc apyarentls tour parcous oxiden of tridium. The mafor lot temperature species

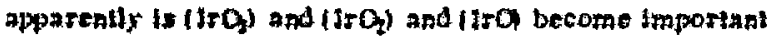
at bfther temperalures. The species $\left(1 r_{2} C_{2}\right)$ forta exothermally and is usully a minor spectes. However, at high exitgen presatures axt at low temperatures il may toe possiblo fer $\left(t_{2}\left(O_{1}\right)\right.$ to predominate.

3. Kintle studies. A number of workers have

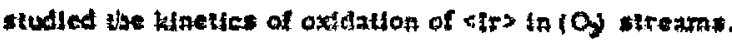
Krter and Jaffec ${ }^{36}$ hated <irs in stresm of alt loxycen pretsure $=0.2 \mathrm{~atm}$ and pubtithed rake loss values for three inmperatures, $1000^{\circ}, 1200^{\prime \prime}$ and $1400^{\circ} \mathrm{C}$. They employed ar rate of aboul $2 \mathrm{fV}$ min.

kurlakose. Keat and stargeare 35,97 heated afs oter the range $1200-3220^{\circ} \mathrm{C}$ in a $1 \mathrm{Fe} \mathrm{O}_{2}$ streath (presture $Q_{2}=0.2$ atm moving al ayout $103 \mathrm{th} / \mathrm{math}$. They also beaked ctro oret be ronge $1490-2220^{\circ} \mathrm{C}$ in $* 116-\mathrm{O}_{2}$ stream (pressure $O_{2}$ o $0.02 \mathrm{~atm}$ hovlac at aboul $25 \mathrm{f} /$ min. Tbese date are surnmarlzed th Table A-32. They also fertormed a muber of experiments to determine the effects of oxyten pressure, oxyten now rate, setapes. ature and the presence of waler vapor in the now stream. Rexer 38,39 hosled $\left\langle\right.$ ir $>$ in Ar- $O_{2}$ streame, employ Ins mucb alther now rates. To meaured che linear recession rates over the curec $1250-2900^{\circ} \mathrm{C}$. cmploying an Ar- $\mathrm{h}_{2} \mathrm{O}$ stream (prenture $\mathrm{O}_{2}=0.19 \mathrm{etm}$ ) mothg at about 12,000 $\mathrm{H} / \mathrm{min}$. Ite atso determined ono point at a now rate of 12,000 $\mathrm{A} / \mathrm{min}$ (pressure $\mathrm{O}_{2}=0.019 \mathrm{~atm}$ and 3 polnte over the rance $1540-1900^{\circ} \mathrm{C}$ with a now rate of 
$25,000 \mathrm{a} / \mathrm{min}$ (pressurc $\left.O_{2}, 0.93 \mathrm{Htm}\right)$. The resw:9s are Iisted in table A-32. In general, Rexer's resules are In sood arreemeat wh those oblained by Kurfaknse, Kent and Mtarerate.

The data of krier and Jaffec and of kiuriakose et al.. oblainad al an ( $O_{2}$ ) pressure of $0.2 \mathrm{~atm}$ ans the dats of Nexer tolatned at an oxycen pressure of 0.19 atm are glotted in sig. 3. Also plotud in Fig. 3 are values for the recestion rate calculated, asstuming the vapor spectes to be (troj), from the tree enercy ralues oblalnof In the mast spectrometric experiment, Eq. (41), and if the tranpiration expertments, Eqs. $(42),(45)$ and (44. In simliar manater tho date of kurlakose et al. oblatred al an oxymen pressure of $0.02 \mathrm{stm}$, and the winte point of Rexer, oblained at an oxyces pressurc of 0.015 atm, are compared to the calculated recenstion Fates if Fits. 4.

The calcutated recextlon rates wero oblained as follows. If the rapor specios indeed (IrQ), the reaction is fiven by Ba. \$39 and be treo energy is

$$
\begin{aligned}
\Delta 0 & =-\mathrm{AT} \text { In } \\
& =-\mathrm{ATI} \text { In } \mathrm{P}_{\mathrm{IrO}}-1.5 \ln \mathrm{PO}_{\mathrm{O}_{2}} \text {. }
\end{aligned}
$$

Given a value for $\triangle O$, calculated from the mass spectromotric data in the range $1557-1747^{\circ} \mathrm{C}$, or trom the transpiration dats in the rafige $1000-1400^{\circ} \mathrm{C}$. togetber with the expertmental talue for the 10 ) pressure, one can calculate a ratue for the (IrOy) pressure. This value can be rolated to the inldium recession rate by use of the Iataysult equalion for free craporation

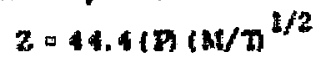

where $\mathrm{M}$ is be motecular waigh of the raporizing spec10: [ bare ftroy T. T is the imperature In degrens Kelvin. D fo the pressure in acmowpherex, and $a$ is the fiux in Uante of $\mathrm{gcm}^{2}$ - Hec. Aridium bas a density of $22.42 \mathrm{~g}$ $\mathrm{cm}^{2}$, therefore, a plece of ctr> $1 \mathrm{~cm}$ lons by $1 \mathrm{~cm}$ lons,

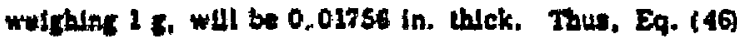
can be converted to yietd the recesston rales in units of $\mathrm{mit} / \mathrm{b}$.

The curves plitud In Fif. 3 demonmirate that the experimantal data of Kurtakose et al. , oblained employing a flow rate of $100 \mathrm{fumin}$. and the dnta of Rexer, obtained - How tate of $12,000 \mathrm{~m} / \mathrm{min}$, are in rassombly good agreement. Datn obte ined in both studies indicate that the recession rates vary with the flow rate, increasing quite rapidly at Iirst, and then more slowly, belng approximately propartional to the logarithm of the flow rate over a large range. The recession rates obtained by Kricr IInd Jaffee are much lower than those obtained in the olbar studies. This may simply be because thelr flow rate, $2 \mathrm{ft} / \mathrm{min}$, was too low. Two other conclusions tha: may be drawn from the data of Kuriakose et al.. and Rexer are that, (1) the recession rates vary nearly linearly with $\left(\mathrm{O}_{2}\right)$ pressure and (2) the presence of water vapor increases the recesston rates.

The calculated recession rates obtained from the mass spectrometric data agree with the experimental values better than do the rates calculated from the transpiration data. In nefther case, however, is the agreement gocid. This discrepancy in the vajues for the calcut ated and experimental recesaton rates could be due to several linclors; (1) There is a kinetic barrier that slows down the recesston rate, (2) the vaporization mechanisms are complex and Involve spceies other than (IrOH) and (3) the data are wrons. The first and second factors are the most Itke causes of the differences. The data of Kurlakose et al. . Imply that (1) at low temperatures, the oxidation rate is low and is surface-reaction controlled, and (2) at higber temperatures, the receaslon rates are less cemperature dependent and are controlled by mass transfer through a boundary layer.

1. Summary. Unfortunately, the phase diagram for the Ir-O system is complex and It has not been fully determlned. For many regtons of the phase diagram no dats exjat. In addition, for those reglons where more than one study was made, the comparitive agreement is often poor. Obviously mucb work needs to be done before one can confidently predict behavior in a complex system such as Pu-O-Ir-C. For the analysis of the MHW system int follows, It was decided to employ those values that lead to the worst case l.e., maximum calculated interaction between the plutonium oxide fuel and the iridlum clad. 


\section{H. Plutonium - Iridium System}

Olsen $^{40}$ has heated $<\mathrm{PuIr}_{2}>$ in a tungsten Knudsen

cell over the temperature range $1680-2210^{\circ} \mathrm{K}$, and determined that $\left\langle\mathrm{PuIr}_{2}>\right.$ vaporizes according to the reaction

$$
\left.\left\langle\mathrm{PuIr}_{2}\right\rangle=(\mathrm{P} u)+2<\mathrm{Ir}\right\rangle \text {. }
$$

The ( $\mathrm{P} u$ pressure is given by

$$
\log P_{\mathrm{Pu}}(\mathrm{atm})=4.26-26,529 / \mathrm{T}_{2}{ }_{\mathrm{K}}
$$

From the vapor pressure data, the free energy for $\mathrm{Eq}$.

(47) is calculated:

$$
\Delta G_{1900}=121,391-19.49 \mathrm{~T},{ }^{\circ} \mathrm{K} \text { (cal/mole) } \text {. }
$$

When Eqs. (47) and (49) are combined with the values listed in Table A-3 for the vaporization of $\{\mathrm{Pu}$, one obtalns for the reaction

$$
\text { [Pu }+2\langle\text { Ir }\rangle=\left\langle\text { Purr }_{2}\right\rangle
$$

the free energy of formation

$$
\Delta G_{1900}=-41,071-3.24 T_{1}{ }^{0} \mathrm{~K} \text { (cal } / \text { mole). }
$$

In the calculations that follow, values for the free energy of formation for $\left\langle\mathrm{PuIr}_{2}\right\rangle$ are taken frcm Eq. (51). Values for the dissociation pressure of $(\mathrm{Pu})$ above $\left\langle\mathrm{PuIr}_{2}\right\rangle$ are taken from $\mathrm{Eq}_{\text {. }}$ (48).

\section{Plutonium - Carbon System}

The results of several investigations of the thermodynamic properties of the $\mathrm{Pu}-\mathrm{C}$ system have recently been published ${ }^{(41-50)}$. The most recent study by Campbell, Kent and Leary ${ }^{50}$ combined mass spectrometric and emf techiques to determine the free energy of formation values for $\left\langle\mathrm{PuC}_{0 \cdot \theta}\right\rangle,\left\langle\mathrm{PuC}_{1} \cdot 5\right\rangle$ and $\left\langle\mathrm{PuC}_{2}\right\rangle$. The results of this study ${ }^{50}$ may be summarized as follows.

The mass spectrometric data indicate that there are four regions of the $\mathrm{Pu}-\mathrm{C}$ phase diagram that give rise to invarient but non-congruent vaporization. These are, monocarbide plus sesquicarbide, sesquicarbide plus carbon, sesquicarivide plus dicarbide and dicarbide plus carbon. At a given, constant temperature the vaporization behavior is as follows. The pressure of $(\mathrm{Pu})$ above $\{\mathrm{Pu}\}$ at $1700^{\circ} \mathrm{K}$ is $4.8 \times 10^{-6} \mathrm{~atm}$. As carbon is added to the system, the (Pu) gradually decreases as the plutonfum activity is lowered. The (Pu) pressure is $4.5 \times 10^{-6}$ atm at a $\mathrm{C} / \mathrm{Pu}$ ratio of 0.70 . As the monocarbide is approached from the low-carbon side the (Pu) pressure decreases rapidly, reaching $4.0 \times 10^{-6} \mathrm{~atm}$ at a $\mathrm{C} / \mathrm{Pu}$ ratio of 0.76 .
Between the compositions $\left\langle\mathrm{PuC}_{0.88}\right\rangle$ and $\left\langle\mathrm{PuC}_{1} . \mathrm{P}\right\rangle$ the pressure is constant at $9.8 \times 10^{-7}$ atm go long as the condensate contains both mono- and sesquicarbide. Between

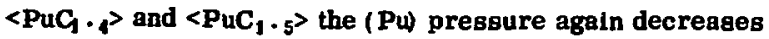
rapidly, becoming $5.3 \times 10^{-7} \mathrm{~atm}$ at $\left\langle\mathrm{PuC}_{1} \cdot 1 \mathrm{1}^{2}\right\rangle$. The lowcarbon phase boundary for the sesquicarbide curves toward lower C/Pu ratios as the temperature increases, passing through $\left\langle\mathrm{PuC}_{1 \cdot 46}\right\rangle$ at $1300 \pm 50^{\circ} \mathrm{C}$ and $\left\langle\mathrm{PuC}_{1 \cdot 41^{\prime}}\right\rangle$ at $1500 \pm 50^{\circ} \mathrm{C}$. Between the compositions $\left\langle\mathrm{PuC}_{1} \cdot \mathrm{S}\right\rangle$ and $\langle\mathrm{C}\rangle$ the $(\mathrm{Pu})$ pressure at $1700^{\circ} \mathrm{K}$ remalns constant at $2.2 \times 10^{-8}$ atm so long as the condensate consists of both sesquicarbide and carbon. At $1660 \pm 10^{\circ} \mathrm{C}$, the sesquicarbide transforms to the dicarbide. Above $1660^{\circ} \mathrm{C}$ and at $\mathrm{C} / \mathrm{Pu}$ ratios of 1.5 or greater, the ( $\mathrm{Pw}$ ) pressure is independent of composition so long as the condensate consiste of both sesqui- and dicarbide. At the composition $\left\langle\mathrm{PuC}_{1} \cdot n+0 \cdot a Q_{1}\right.$, and above $1660^{\circ} \mathrm{C}$, the condensate consists of $\left\langle\mathrm{PuC}_{2}\right\rangle$ plus $<C>$ and the $(P W)$ pressure is invarient. At temperatures above $2100^{\circ} \mathrm{K}$, trace amounts $(<1 \%)$ of $\left(\mathrm{PuC}_{2}\right)$ were observed

The following tharmodynamic values are taken from the mass spectrometric and emf study of Campbell, Kent and Leary ${ }^{50}$.

Below $1660^{\circ} \mathrm{C}$ plutonium sesquicarbide decomposes to the elements according to the equation

$$
\left.\left\langle\mathrm{PuC}_{1 \cdot 5}\right\rangle=(\mathrm{Pu})+1.5<\mathrm{C}\right\rangle \text {. }
$$

The ( $\mathrm{Pu}$ ) pressure, over the range $1670-1933^{\circ} \mathrm{K}$, is given by

$$
\log \mathrm{P}_{\mathrm{Pu}}(\mathrm{atm})=4.468-20,598 / \mathrm{T},{ }^{\circ} \mathrm{K} .
$$

The free energy for the decomposition reaction is given by

$$
\left.\Delta \mathrm{G}_{1842}=94,252-20.44 \mathrm{~T},{ }^{\circ} \mathrm{K} \text { (cal } / \mathrm{mole}\right) \text {. }
$$
When Eqs. (52) and (54) are combined with the values listed in Table A-3 for the vaporization of $\{P u\}$, one obtains for the reaction

$$
\{\mathrm{Pu}\}+1.5\langle\mathrm{C}\rangle=\left\langle\mathrm{PuC}_{1 \cdot 5}\right\rangle
$$

the free energy expression

$$
\left.\Delta G_{f_{1 B Q 2}}=-14,098-2.20 \mathrm{~T},{ }^{0} \mathrm{~K} \text { (cal } / \mathrm{mole}\right) \text {. }
$$

The corresponding expression obtained in the emf study over the range $920-1060^{\circ} \mathrm{K}$, is

$$
\Delta_{\mathrm{G}_{\mathrm{f}_{9 B 6}}}=-16,650+0.35 \mathrm{~T},{ }^{0} \mathrm{~K} \text { (cal } / \mathrm{mole} \text { ). }
$$

Equations (56) and (57) yleld at $1000^{\circ} \mathrm{K}, \Delta G_{\mathrm{f}}=-16.3$ $\mathrm{kcal} / \mathrm{mole}$, in excellent agreement. 
Plutonium monocarbide, when heated, decomposes according to the reaction

$$
\left.2,5<\mathrm{PuC}_{0.9}\right\rangle=(\mathrm{Pu})+1.5\left\langle\mathrm{PuC}_{1} \cdot 5\right\rangle \text {. }
$$

The pressure of ( $\mathrm{Pu}$, over the range $1450-1850^{\circ} \mathrm{K}$, is given by

$$
\log P_{P_{u}}(\mathrm{~atm})=5.118-18,919 / \mathrm{T},{ }^{\circ} \mathrm{K}
$$

which leads to a free energy value for $\mathrm{Eq}$. (58) of

$$
\Delta G_{1862}=86,570-23,42 \mathrm{~T},{ }^{\circ} \mathrm{K} \text { (cal } / \text { mole) } \text {. }
$$

When the free energy of formation expression for $\left\langle\mathrm{PuC}_{0.8}\right\rangle$ is combined with those for the formation of $\left\langle\mathrm{PuC}_{1} \cdot{ }_{5}\right\rangle$ and the vaporization of $\{\mathrm{Pu}\}$, one obtalns for the reaction

$$
\{\mathrm{Pu}\}+0.9<\mathrm{C}\rangle=\left\langle\mathrm{PuC}_{0.9}\right\rangle \text {, }
$$

the value

$$
\Delta G_{1682}=-11,487-0.74 T,{ }^{\circ} \mathrm{K} .
$$

The corresponding expression obtained in the emf study over the range $920-1060^{\circ} \mathrm{K}$ is

$$
\Delta \mathrm{G}_{\mathrm{B22}}=-14,059+1.60 \mathrm{~T},{ }^{\circ} \mathrm{K} \text {. }
$$

The average third low value for the heat of formation for $\left\langle\right.$ PuC $_{0.9}>$, obtained in the mass spectrometric and emf studies, Eqs. (62) and (63), is $\Delta H_{f_{218}}^{0}=-11.1 \mathrm{kcal} / \mathrm{mole}$. This fs in excellent agreement with the value $\Delta \mathrm{H}_{f_{283}^{0}}^{0}=$ $-11.4 \mathrm{kcal} / \mathrm{mole}$, obtained in a recent bomb-calorimeter experiment.

At $\mathrm{C} / \mathrm{Pu}$ ratios greater than 1.98 and at temperatures above $1660^{\circ} \mathrm{C}$, plutonium dicarbide deromposes according to the reaction

$$
\left.\left\langle\mathrm{PuC}_{2}\right\rangle=(\mathrm{Pu})+2<\mathrm{C}\right\rangle \text {. }
$$

The ( $P u$ ) pressure over the range $1933-2140^{\circ} \mathrm{K}$ is given by

$$
\log P_{P_{u}}(\mathrm{~atm})=3.787-19,288 / \mathrm{T}_{1}{ }^{\circ} \mathrm{K}
$$

and the free energy for the decomposition reaction is given by

$$
\Delta \mathrm{G}_{2056}=88,258-17.33 \mathrm{~T},{ }_{\mathrm{K}} \text { (cal/mole). }
$$

When the free energy expression for the decompositton of $<\mathrm{PuC}_{2}>$ Is combined with that for the vaporization of $\{\mathrm{Pu}\}$ one obtaing for the reaction

$$
\{\mathrm{Pu}\}+2\langle\mathrm{C}\rangle=\left\langle\mathrm{PuC}_{2}\right\rangle
$$

the value

$$
\left.\Delta G_{2056}=-7,574-5.58 \mathrm{~T},{ }^{0} \mathrm{~K} \text { (cal } / \mathrm{mole}\right) .
$$

\section{J. Plutonium - Oxygen - Carbon Sygtem}

The Pu-O-C system has not been studied as extensively as the Pu-O or Pu-C systems. Mulford et al.. have reported the existence of a single-phase fleld having a stoichiometry ranging from about $\left\langle\mathrm{PuO}_{0 .{ }_{36}} \mathrm{C}_{0.61}\right\rangle$ to $\left\langle\mathrm{PuO}_{0.65} \mathrm{C}_{0.35}\right\rangle$. They present lattice parameters for the various compositions. Potter ${ }^{52,53}$ reported that a composition near $\left\langle\mathrm{PuO}_{0.5} \mathrm{C}_{0.5}\right\rangle$ vaporizes congruently over the rasge $1600-1820^{\circ} \mathrm{K}$, according to the reaction

$$
\left\langle\mathrm{PuO}_{0.5} \mathrm{C}_{0.5}\right\rangle=(\mathrm{Pu})+0.5(\mathrm{CO})
$$

where

$$
\left.\Delta \mathrm{G}=150,150-54.5 \mathrm{~T},{ }^{\circ} \mathrm{K} \text { (cal } / \mathrm{mole}\right) .
$$

From this, one calculates for the free energy of formation for $\left\langle\mathrm{PuO}_{0 .} \mathrm{B}_{0.5} \mathrm{C}_{0.5}\right.$

$$
\left.\Delta \mathrm{G}_{\mathrm{f}}=-65,500+11.5 \mathrm{~T},{ }^{\circ} \mathrm{K} \text { (cal } / \mathrm{mole}\right) \text {. }
$$

\section{K. Plutonium - Oxygen - Carbon - Iridium Sygtem}

Very little information has been published for the Pu-O-C-Ir system. However, considerable data pertaining to the MHW Bystem will result from the compatibility tests being conducted at LASL and other laboratories.

Reavis ${ }^{54}$ has conducted a series of experiments in which he heated $\left\langle\mathrm{PuO}_{2}\right\rangle$ in an Iridium cruclble contained In a graphite susceptor. The results are summarized in Table A-33. The reaction at about $2275^{\circ} \mathrm{C}$ is belfeved to be due to the formation of the $\mathrm{Ir}-\mathrm{C}$ eutectlc, allowing the $\left\langle\mathrm{PuO}_{2}\right\rangle$ to react directly with the outer graphite container to produce $(\mathrm{CO})$.

\section{Miscellaneoug}

The thermodynamic functiong for $\left(\mathrm{H}_{2}\right),\left(\mathrm{H}_{2} \mathrm{O},(\mathrm{CO})\right.$ and $\left(\mathrm{CO}_{2}\right)$ used in the calculations that follow are taken from the JANAF tables. These functions are listed in Tables A-34 through A-37.

\section{CALCULATION OF POSSIBLE REACTIONS}

\section{A. Basis for Calculations}

The thermodynamic data discussed in section II above and gummarized in Appendix A (Tables A-1 to A-37) weice employed to calculate equillbrium free energy values for the reactions for $\left\langle\mathrm{PuO}_{2}\right\rangle$ and various components of the MHW system. 
B. $\left\langle\mathrm{PuO}_{2}\right\rangle+\langle\mathrm{C}\rangle$

Under normal operational condittons the $\left\langle\mathrm{PuO}_{\varepsilon}\right\rangle$ fucl in the FSA should never come in contact with graphite. Iridium does not form a compound with carbon and the only reported ir-C eutectic temperature is higher than predicted reentry temperatures. Reactions between the fuel and the graphite could occur if the irfdium sbell was mechanically breached or if impurities wcre present in sufficient quantites to stgnificantly lower the ir-C eutectfe temperature.

Reactions between $\left\langle\mathrm{PuO}_{2}\right\rangle$ and $\langle\mathrm{C}\rangle$ to form $\left\langle\mathrm{PuO}_{2}-x\right\rangle$ plus ( $\mathrm{CO}$, as well as the various plutonlum carbides, arc summarized in Appendix B (Tablizs B-1 to B-17). The calculated free energy salues are based on equllibrium conditions for closed systems and indicate that for such aystems, no reactlons occur below about $1400^{\circ} \mathrm{K}$. At higher temperatures, reactions can occur and lower $\mathrm{O} / \mathrm{Pu}$ ratios become more favored as the temperature increases. For any temperature at which reaction can occur, the reaction can be driven further than predicted by the free energy values if the products can be removed. Such would occur if the breached FSA were vented to vacuum ( space). In fact, plutonium carbides are often made by vacuum reduction of $\left\langle\mathrm{PuO}_{2}\right\rangle$ by graphite.

Temperatures at which the equilibrium $\Delta G$ value becomes negative for the reaction between $\left\langle\mathrm{PuO}_{2}\right\rangle$ and $<$ ( > to form a specific reduced oxide are summarized in TEble B-78.

\section{c. $\left\langle\mathrm{PuO}_{2}\right\rangle+(\mathrm{CO})$}

Carbon monoxide should not be generated within an

FSA. However, ( $\mathrm{CO}$ ) could be produced by reaction between the graphite and an impurity outside an FSA or if the irfdium shell were breached allowing the graphite to come in contact with the fuel. Reactions between $\left\langle\mathrm{PuO}_{2}\right\rangle$ and $(\mathrm{CO})$ at various temperatures are summarized in Appendix B (Tables B-18 to B-34) and indicate no reacthon occurs under equilibrium conditions below about $1700^{\circ} \mathrm{K}$. At higher temperatures, however, (CO will reduce $\left\langle\mathrm{PuO}_{2}\right\rangle$ to $\left\langle\mathrm{PuO}_{2-\mathrm{x}}\right\rangle$ with the $\mathrm{O} / \mathrm{Pu}$ ratio decreasIng as the temperature increases. An experimental program has been initiated at LASL to determine the exact amount of reduction that occurs.
Temperatures at which the equfibrium $\Delta G$ value becomes negative for the reaction between $<\mathrm{PuO}_{2}>$ and ICO to form s specifle reduced oxide are summarized in Table $\mathrm{B}-78$.

\section{D. $\left\langle\mathrm{PuO}_{2}\right\rangle+(\mathrm{H}) /\left(\mathrm{H}_{2} \mathrm{O}\right.$}

Workers at EASL and other laboratorles routinely adjust sample stoichlomctries isy $\left(t t_{2}\right)$ reduction of $\left\langle P u O_{2}\right\rangle$ above $1300^{\circ} \mathrm{C}$. Becausc moisturc can be introduced when FSA's are bandled, the reactions between $\left\langle\mathrm{PuO}_{2}\right\rangle$ and $\left(\mathrm{H}_{2}\right) / \mathrm{H}_{2} \mathrm{O}$ arc summarized in Tables B-35 to B-51. Again, the temperatures at which the equllibrium $\Delta G$ value becomes negative for the reaction between $\left\langle P u O_{\text {q }}\right\rangle$ and $\left(\mathrm{H}_{2}\right)$ to form a specific suboxide are summarized in Tablc B-78. Obviously, below these temperatures, $\left\{\mathrm{H}_{2} \mathrm{O}\right.$ will oxidize $\left\langle\mathrm{PuO}_{2}-\mathrm{x}\right\rangle$.

E. $\left\langle\mathrm{PuO}_{2}\right\rangle+\langle 1 \mathrm{Ir}\rangle$

1. $\left\langle\mathrm{IrO}_{2}\right\rangle$. Free energy values for the reactions between $\left\langle\mathrm{PuO}_{3}\right\rangle$ and $\left.<\mathrm{lr}\right\rangle$ to form $\left\langle\mathbf{I r} \mathrm{O}_{2}\right\rangle$ are oummarized in Tables B-52 to B-58. These values Indicate that telow the decomposition temperature of $\left\langle\mathrm{trO}_{2}\right\rangle,\left\langle\mathrm{PuO}_{2}\right\rangle$ wit! not react with $\langle$ Ir $\rangle$ to form $\left\langle\mathrm{IrO} \mathrm{O}_{2}\right\rangle$. However, abould any $\left.<\mathrm{IrO}_{2}\right\rangle$ be initially present as an impurity in the iridium, it will decompose on heating with possibly serious consequences. This will be diacussed in section IV below.

2. $\left(\left[r \mathrm{O}_{2}\right)\right.$. Free energy values for the reactions between $\left\langle\mathrm{PuO}_{2}\right\rangle$ and $\langle\mathrm{Ir}\rangle$ to form (IrO) are summarized in Tables B-59 to B-67. These values indfcate that, under equllibrium conditions in a closed system, no reavtion occurs. However, under sperating conditlons the fuel sphere will release $\left(O_{2}\right)$ that can react with the Iridfum shell to produce (Ir $\left.\mathrm{O}_{2}\right)$. These reactions will be dlscussed below in section IV.

3. (IrO) . Free energy values for the possible reactlons between $\left\langle\mathrm{PuO}_{2}\right\rangle$ and $\left.<\mathrm{Ir}\right\rangle$ to form ( $\mathrm{IrO}_{3}$ ) are summarized in Tables B-68 to B-77. For this analysis the free energy of formation values for ( $I r O_{\text {f }}$ ) were taken from the transpiration data, Eqs. (42), (43) and (44), because these data yleld the worst case, maximum irfdium transport as $\left(1 r O_{3}\right)$. These free energy data predict no reaction between $\left\langle\mathrm{PuO}_{2}\right\rangle$ and $\langle\mathrm{Ir}\rangle$ to form $\left(\mathrm{ICO}_{3}\right)$. However, at high temperatures, $\left(O_{2}\right)$ from the dissociation of 
the fuel couid react with the iridium shell to produce $\left(\mathrm{IrO}_{3}\right)$. These reactlons will be ..sscussed below in secHon $T$.

4. $\left\{\mathrm{Ir}_{2} \mathrm{O}_{3}\right.$ jand (IrO). Mass spectrometric data ${ }^{32}$ indicate that (IrO) is not an important species at any temperature predicted for normal FSA operation inciuding reentry. While $\left(\mathrm{It}_{2} \mathrm{O}_{3}\right)$ is known to exist, no thermodynamic data are available. Given the conditions under whtch this spectes was observed, 35 low temperatures and hlgh oxygen pressures, it is not likely $\operatorname{lat}\left(\mathrm{Ir}_{2} \mathrm{O}_{3}\right)$ will be formed under normal FSA operating conditions.

\section{F. $\quad\langle$ Ir $\rangle+\langle\mathrm{C}\rangle$}

No reaction to form a compound will occur below $3000^{\circ} \mathrm{C}$. The reported sutectic temperature, $2296 \pm 20^{\circ} \mathrm{C}$ is well above predicted reentry tenperatures.

\section{THERMODYNAMIC ANAL,YSIS FOR A MHW-F'SA}

\section{A. Basic Assumplions and Equations}

1. Fuel. For the analyses that follow, a number of assumptions have been macie about the fuel.

a. The fuel consists of a 100 watt sphere with the initial stotchiometry $\left\langle\mathrm{P}_{\mathrm{HO}_{2} \cdot 0}\right\rangle$. The ${ }^{238} \mathrm{Pu}$ lsotope contributes 80 at. $\%$ of the total plutonium content, thus a 100 watt sphere weigha $251.5 \mathrm{~g}\left(0.93\right.$ moles $\left.\left\langle\mathrm{PuO}_{2} .0\right\rangle\right)$.

b. The sphere diameter at $20^{\circ} \mathrm{C}\left(68^{\circ} \mathrm{F}\right)$ is

1.465 in. Sphere diameters at other temperatures are calculated by correcting for the thermal expansion of plutonium dioxide 55 . Values for the diameter and surface area of a 100 watt gphere are listed for various temperatures In Table C-1.

c. The equilibrium partial pressure values for $\left(\mathrm{O}_{2}\right)$, ( $\left.\mathrm{PuO}_{2}\right)$, (PuO) and ( $\left.\mathrm{Pu}\right)$ above any $\left\langle\mathrm{PuO}_{2}-\mathrm{x}\right\rangle$ composition are those given for various temperatures in sectlon II ( Tables A-9 to A-19).

d. The rate at which the species $\left(\mathrm{O}_{2}\right),\left(\mathrm{PuO}_{2}\right)$, (PuO) and ( $P u$ ) leave the gurface of a fuel sphere maybe calculated from the Langmuir equation

$$
Z=(44.36)(F)(M / T)^{1 / 2}
$$

where $Z$ is the loss rate in $\mathrm{g} / \mathrm{cm}^{2}$ sec, $P$ is the pressure in atmospheres, $T$ is the ternperature in degrees Kelvin and $M$ is the molecular weight of the vaporizing species.
For these calculations, instant diffusion of material through the sphere to the surface is assumed. Also, the evaporation coefficient is assumed to be unity. Thus, the calculated rate loss values will be maximum ones.

2. Iridium Shell. Some assumptions have also been made for the iridium shell.

a. The iridium shell is $0.02 \mathrm{in}$. thick and has an 1.d. wf $1.56 \mathrm{in.}$ This leads to an inner surface area of about $49.3 \mathrm{~cm}^{2}$. For the sake of simplicity, it is assumed that the free volume inside the FSA is constant over a temperature range, 1.e., both the fuel sphere and the iridium shell expard as the temperature increases.

b. The iridium shell is provided with two vents, 0.002 in. diam., so that the total vent or orifice area is $4.054 \times 10^{-5} \mathrm{~cm}^{2}$. Ideal gas behavior is assumed so that the effusion of gases through the vents is given by the Knudsen equation

$$
\mathbf{P}=\frac{\mathrm{KW}}{\mathrm{AtW}}\left[\frac{\mathrm{T}}{\mathrm{M}}\right]^{1 / 2}
$$

where $P$ is the pressure in atmospheres, $T$ is the temperature in degrees Kelvin and $w$ is the weight, in $g$, of materfal of molecular weight $M$, that effuses through an area of $A \mathrm{~cm}^{2}$ in a time $t$ sec. The constant $K$ is derived from the kinetic theory of gases and is equal to 0.02256 . The ideal Knudsen equation assumes a hole with infiaitely thin knife-edges. The vents of the FSA will exert a channelIng effect and the number of molecules escaping will be less than predicted. Theoretical corrections for this channel effect have been derived by clausing and for a bng narrow tube the correction is $W=8 r / 31^{56}$. For the FSA vents, $r=0.001$ in, $1=0.02$ in and $W=0.1333$.

\section{B. $1700^{\circ} \mathrm{K}$}

The predicted maximum surface temperature for the fuel sphere under operating conditions is about $1700^{\circ} \mathrm{K}$ $\left(1427^{\circ} \mathrm{C}\right)$. The calculated equilibrium partfal pressures for $\left(\mathrm{O}_{2}\right),\left(\mathrm{PuO}_{2}\right),(\mathrm{PuO})$ and $(\mathrm{Pu})$ above $\left\langle\mathrm{PuO}_{2} \cdot 0\right\rangle$ at this temperature are listed in Table A-9. The effects of the vaporization of each of these species will be discussed.

1. Oxygen. The data in Table A-9 indicate that the predominate vapor species is $\left(O_{2}\right)$ with a partial pressure of $2.5 \times 10^{-6} \mathrm{~atm}$. This will lead to a reduction of the $\mathrm{O} / \mathrm{Pu}$ ratio in the fuel. The amount of oxygen given off 
as $\left(O_{2}\right)$ can be calculated from the Langmuir equation, Eq (72), to be

$$
\begin{aligned}
\mathrm{Z}_{\mathrm{O}_{2}} & =(44.36)\left(2.5 \times 10^{-9}\right)(32 / 1700)^{1 / 2} \\
& =1.52 \times 10^{-6} \mathrm{~g} / \mathrm{cm}^{2} \mathrm{sec} .
\end{aligned}
$$

At $1700^{\circ} \mathrm{K}$, the sphere surface area is $44.88 \mathrm{~cm}^{2}$ (Table C-1) so that the $\left(\mathrm{O}_{2}\right)$ loss rate becomes

$$
\mathrm{Z}_{\mathrm{O}_{2}}=6.8 \times 10^{-4} \mathrm{~g} / \mathrm{sec} \text {. }
$$

a. Fuel Reduction. In order for $0.93 \mathrm{moles}$ of $\left\langle\mathrm{PuO}_{2} \cdot 0\right\rangle$ to be reduced to 0.93 moles of $\left\langle\mathrm{PuO}_{1} \cdot 98\right.$, a total of $0.93 \times 0.02 \times 16=0.3 \mathrm{~g}$ of oxygen must be removed. From Eq. (75) one finds that the minimum time required to move this amount of oxygen is $441 \mathrm{sec}$ or 7.4

min. This is a mintmum time because of the assumptions noted above in section IV. A, i.e., instant diffusion and an evaporation coefficient of unity.

Once the fuel is reduced to $\left\langle\mathrm{PuO}_{1} \cdot \mathrm{gB}_{8}\right\rangle$, the $\left(\mathrm{O}_{2}\right)$ pressure becomes $4.9 \times 10^{-11} \mathrm{~atm}$ (Table A-10). The oxycen loss rate is then

$$
\begin{aligned}
\mathrm{Z}_{\mathrm{O}_{2}} & =(44.36)\left(4.9 \times 10^{-11}\right)(32 / 1700)^{1 / 2} \\
& =3.0 \times 10^{-10} \mathrm{~g} / \mathrm{cm}^{2} \mathrm{sec}_{2}
\end{aligned}
$$

or for a surface area of $44.88 \mathrm{~cm}^{2}$

$$
\mathrm{Z}_{\mathrm{O}_{2}}=1.3 \times 10^{-8} \mathrm{~g} / \mathrm{sec} \text {. }
$$

For the sphere to be reduced from $\left\langle\mathrm{PuO}_{1} \cdot{ }^{6}\right\rangle$ to $\left\langle\mathrm{PuO}_{1 \cdot 95}\right\rangle$, a total of $0.93 \times 0.03 \times 16=0.45 \mathrm{~g}$ of oxygen must be removed. The minimum time required for this to occur, calculated from Eq. (77) is $3.46 \times 10^{7} \mathrm{sec}$ or $1.1 \mathrm{y}$. Similar calculations indicate much longer times are required for the fuel to be reduced from $\left\langle\mathrm{PuO}_{1} \cdot 95\right\rangle$ to $\left\langle\mathrm{PuO}_{1} \cdot 92\right\rangle$, etc. Thus, unless a driving force such as vacuum operation is present, the fuel would not be reduced to the congruently vaporizing composition of $\left\langle\mathrm{PuO}_{1} \cdot 9_{0}\right\rangle$, ( Table A20), during any expected mission lifetime at $1700^{\circ} \mathrm{K}$.

\section{b. Effusion of $\left(O_{2}\right)$ from the FSA. If the $\left\{O_{2}\right\}$} partial pressure above $\left\langle\mathrm{PuO}_{2} . \mathrm{O}\right\rangle$ at $1700^{\circ} \mathrm{K}$ is $2.5 \times 10^{-6}$ atm, the amount effusing out the vents, calculated from the Knudsen equation, Eq. (73), is

$$
2.5 \times 10^{-6}=\frac{0.02256 \mathrm{w}}{\left(4.054 \times 10^{-5}\right)(t)(0.1333)}\left(\frac{1700}{32}\right)^{1 / 2}
$$

$$
w_{\mathrm{O}_{2}}=8.2 \times 10^{-11} \mathrm{~g} / \mathrm{sec} \text {. }
$$

This value may be compared to the $\left(O_{2}\right)$ loss rate at the sphere surface, $6.8 \times 10^{-4} \mathrm{~g} / \mathrm{sec},[\mathrm{Eq} .(75)]$. For the fuel to be reduced from $\left\langle\mathrm{PuO}_{2}\right\rangle$ to $\left\langle\mathrm{PuO}_{1} \cdot 98\right\rangle, 0.3 \mathrm{~g}$ of oxygen must be removed. The time required for this amount to effuse out of the FSA, calculated from Eq. (78) is about 116 y. Thus, an $\left(O_{2}\right)$ overpressure in the FSA will prevent further reduction of the fuel and the actual fuel stoichiometry will stabilize somewhere between $\left\langle\mathrm{PuO}_{2} \cdot 0\right\rangle$ and $\left\langle\mathrm{PuO}_{1} \cdot 98\right\rangle$.

c. Effect of $(O)$. The $(O)$ pressure at $1700^{\circ} \mathrm{K}$, corresponding to an $\left(O_{2}\right)$ pressure of $2.5 \times 10^{-6} \mathrm{~atm}$, is $7.0 \times 10^{-8} \mathrm{~atm}$. The total (O) loss rate from the sphere surface, calculated using the Langmuir equation, is $\mathrm{Z}_{\mathrm{O}}=$ $1.4 \times 10^{-5} \mathrm{~g} / \mathrm{sec}$. Thus, the $(O)$ contribution to the oxygen loss rate is about $2 \%$ that due to $\left(O_{2}\right)$.

d. Effect of Helium. At $1700^{\circ} \mathrm{K}$, the $\left(\mathrm{O}_{2}\right)$ loss rate from the surface of a $<\mathrm{PuO}_{2}>$ sphere is $6.8 \times 10^{-4} \mathrm{~g} /$ sec, $[\mathrm{Eq} \cdot(75)]$. This value corresponds to $1.3 \times 10^{19}$ particles/sec. Current program plans call for a vacuum degassing of the FSA'B prior to launch so that they will begin the mission without appreciable helium inventories. Plutonium dioxide (80 at. $\left.\%{ }^{238} \mathrm{Pu}\right)$, generates helium at

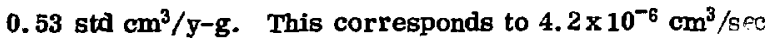
for 0.93 moles $\left\langle\mathrm{PuO}_{2}>\right.$ or $1.1 \times 10^{14}$ helium atoms $/ \mathrm{sec}$. Thus, $\left\langle\mathrm{PuO}_{2}>\right.$ will generate approximately $10^{5}\left(\mathrm{O}_{2}\right)$ molecules per (He) atom, and helium generation should not appreciably affect the $\left(O_{2}\right)$ loss rate. After an extended period of time, tha (He) pressure will come to an equilibrium va'... of about $0.1 \mathrm{~atm}$. This would further suppress the reduction of the fuel by $\left(O_{2}\right)$ evaporation.

e. Reactions with the Iridium Shell. It was noted above in section III and in Tables B-52 to B-77, that the calculated $\Delta G$ values predict no reaction between $\left\langle\mathrm{PuO}_{2}\right\rangle$ and $<\mathrm{Ir}>$. However, the $\left(\mathrm{O}_{2}\right)$ released by the fuel might react with the $<\mathrm{Ir}>$ shell, thus removing some of the free oxygen in the system and providing a driving force for further reduction of the fuel.

For the reaction

$$
\langle\operatorname{Ir}\rangle+1.5\left(\mathrm{O}_{2}\right)=\left(\mathrm{IrO}_{3}\right)
$$

the free energy at $1700^{\circ} \mathrm{K}$, calculated from Eqs. (42), (43) and (44), is

$$
\begin{aligned}
\Delta \mathrm{G} & =-\mathrm{RT} \ln \mathrm{K} \\
& =-\mathrm{RT}\left[\ln \mathrm{P}_{\operatorname{IrO}}{ }^{-1.5} \ln \mathrm{P}_{\mathrm{O}_{2}}\right] \\
& =22.31 \mathrm{kcal} / \text { mole. }
\end{aligned}
$$


The $\Delta G$ values obtained from the transpiration studies are used for this analyses because they lead to the worst case, i. e., maximum ( $\left.\mathrm{IrO}_{3}\right)$ generation. The equilibrium partial pressure of $\left(\mathrm{O}_{2}\right)$ above $\left\langle\mathrm{PuO}_{2}\right\rangle$ is $2.5 \times 10^{-6} \mathrm{~atm}$ at $1700^{\circ} \mathrm{K}$. Thus, the $\left(\mathrm{IrO}_{3}\right)$ partial pressure is $\mathrm{P}_{\mathrm{IrO}_{3}}=$ $5.4 \times 10^{-12} \mathrm{~atm}$. When this value is introduced into the Langmuir equation, the niaximum ( $\mathrm{IrO}_{3}$ ) loss rate from the sheli is calculated to be

$$
\mathrm{Z}_{\mathrm{IrO}}=9.0 \times 10^{-11} \mathrm{~g} / \mathrm{cm}^{2} \mathrm{sec} \text {. }
$$

If the iridium shell inner surface area is $49.3 \mathrm{~cm}^{2}$, this leads to

$$
\mathrm{Z}_{\mathrm{IrO}_{3}}=4.4 \times 10^{-9} \mathrm{~g} / \mathrm{sec} \text {. }
$$

Thts $\left(\mathrm{IrO}_{3}\right)$ generation rate would consume abcut $8.8 \times 10^{-10}$ $\mathrm{g} / \mathrm{sec}$ of oxygen, or in the first $441 \mathrm{sec}, 3.9 \times 10^{-7} \mathrm{~g}$ of oxygen out of the $0.3 \mathrm{~g}$ generated. This reaction of the $\left(O_{2}\right)$ with the $<\mathrm{Ir}>$ at $1700^{\circ} \mathrm{K}$ would not affect the $\left(\mathrm{O}_{2}\right)$ generation rate.

The ( $\left.\mathrm{IrO}_{3}\right)$ generation rate, $\mathrm{Eq} .(81)$, corresponds to a worst case loss rate of iridium from the inner shell surface of about $0.11 \mathrm{~g} / \mathrm{y}$, or about $0.04 \mathrm{mil} / \mathrm{y}$. The rate at which the ( $\left.\mathrm{IrO}_{3}\right)$ could effuse out of the FSA is about $1.5 \times 10^{-8} \mathrm{~g} / \mathrm{y}$.

For the reaction

$$
\langle\mathrm{Ir}\rangle+\left(\mathrm{O}_{2}\right)=\left(\mathrm{Ir}_{\mathrm{O}}\right)
$$

the free energy at $1700^{\circ} \mathrm{K}$, calculated from Eq. $(40)$, is

$$
\begin{aligned}
\Delta G & =-R T\left[\ln P_{\text {IrO }_{2}}-\ln P_{O_{2}}\right] \\
& =41.87 \mathrm{kcal} / \mathrm{mole} .
\end{aligned}
$$

If the $\left(O_{2}\right)$ partial pressure is $2.5 \times 10^{-6} \mathrm{~atm}$, the ( $\left.\mathrm{IrO}_{2}\right)$ partial pressure is calculated to be $\mathrm{P}_{\mathrm{IrO}_{2}}=1.0 \times 10^{-11} \mathrm{~atm}$. The maximum ( $\mathrm{IOO}_{2}$ ) loss rate from the iridium shell, calculated using the Langmuir equation, is

$$
\mathrm{Z}_{\mathrm{IrO}_{2}}=1.7 \times 10^{-10} \mathrm{~g} / \mathrm{cm}^{2} \mathrm{sec}
$$

or, if the inner shell si.rface area is $49.3 \mathrm{~cm}^{2}$,

$$
\mathrm{Z}_{\mathrm{IrO}_{2}}=8.4 \times 10^{-9} \mathrm{~g} / \mathrm{sec} \text {. }
$$

This $\left(\mathrm{IrO}_{2}\right)$ generation rate would require $1.2 \times 10^{-1} \mathrm{~g}$ of oxygen/sec. Thus, in $441 \mathrm{sec}, 4.9 \times 10^{-8} \mathrm{~g}$ of the $0.3 \mathrm{~g}$ of oxygen produced would be taken up. This would not affect the $\left(\mathrm{O}_{2}\right)$ generation rate.
The ( $\mathrm{IrO}_{2}$ ) generation given by Eq. (85) translates to a maximum iridium loss from the inner shell surface of about $0.23 \mathrm{~g} / \mathrm{y}$ or $0.08 \mathrm{mil} / \mathrm{y}$. The effusion rate of $\left(\mathrm{IrO}_{2}\right)$ through the vents is calculated to be about $2.7 \times 10^{-8} \mathrm{~g} / \mathrm{y}$.

At $1700^{\circ} \mathrm{K}$, reactions between the iridium shell and the $\left(O_{2}\right)$ generated by the fuel should not affect the FSA operation.

2. (PuO) L. The equilibrium partial pressure of $\left(\mathrm{PuO}_{2}\right.$ ) above $\left\langle\mathrm{PuO}_{2}>\right.$ at $1700^{\circ} \mathrm{K}$ is $. .1 \times 10^{-10} \mathrm{~atm}$ ( Table A-9) . The maximum loss rate from the sphere surface is calculated to be

$$
\mathrm{Z}_{\mathrm{PuO}_{2}}=3.7 \times 10^{-9} \mathrm{E} / \mathrm{cm}^{2} \mathrm{sec}
$$

or for the total sphere

$$
\mathrm{Z}_{\mathrm{PuO}_{2}}=1.7 \times 10^{-7} \mathrm{~g} / \mathrm{sec} \text {. }
$$

The sphere would lose a maximum of $5.2 \mathrm{~g}\left(\mathrm{PuO}_{2}\right) / \mathrm{y}$.

The amount that could effuse through the vents is $6.3 \mathrm{x}$ $10^{-7} \mathrm{~g} / \mathrm{y}$. The $(\mathrm{PuO})$ generation rate, Eq. (87), leads to a calculated value for the deposit of $\left\langle\mathrm{PuO}_{2}\right\rangle$ on the iridium shell of less than $0.1 \mathrm{mil} / \mathrm{y}$. This should not affect FSA operation.

3. (PuO). The equilibrium partial pressure of ( $\mathrm{PuO}$ ) above $\left\langle\mathrm{PuO}_{2}\right\rangle$ at $1700^{\circ} \mathrm{K}$ is $8.1 \times 10^{-15} \mathrm{~atm}$ ( Table A-9) . This leads to a calculated maximum loss rate of (PuO) from the sphere of $2.0 \times 10^{-4} \mathrm{~g} / \mathrm{y}$. The amount that can effuse through the vents is $2.3 \times 10^{-11} \mathrm{~g} / \mathrm{y}$. Vaporization of (PuO) from the fuel sphere will not affect FSA operation.

\section{4. (Pu). The equilibrium partial pressure of $(\mathrm{Pu})$} above $\left\langle\mathrm{PuO}_{2}>\right.$ at $1700^{\circ} \mathrm{K}$ is $9.7 \times 10^{-24} \mathrm{~atm}$ (Table A-9). This value leads to a maximum calculated loss rate of (Pu) from the sphere surface of $2.3 \times 10^{-13} \mathrm{~g} / \mathrm{y}$. The rate of $(P u)$ effusio: through the vents is calculated to be $2.7 \times 10^{-20} \mathrm{~g} / \mathrm{y}$. These rates will not affect FSA operation.

The (Pu) pressure above $\left\langle\mathrm{PuIr}_{2}\right\rangle$ at $1700^{\circ} \mathrm{K}$ is $4.5 \mathrm{x}$ $10^{-12}$ atm, [Eq. (48)]. The (Pu) given off by the fuel will not react with the shell to form $\left\langle\mathrm{PuIr}_{2}>\right.$ unless the $(\mathrm{Pu})$ pressure above the fuel is greater than $4.5 \times 10^{-12} \mathrm{~atm}$. For this to occur, the fuel must be reduced to a stoichiometry of about $\left\langle\mathrm{PuO}_{1} \cdot \mathrm{7}\right\rangle$ (Tables A-16 and A-17). Given the oxygen results discussed above, this is impossible. 
5. Iridium and Carbon. The vapor pressure of (Ir) above $\langle$ Ir $\rangle$ at $1700^{\circ} \mathrm{K}$ is $2.7 \times 10^{-13} \mathrm{~atm}$, Eq. (32). This corresponds to a loss rate from the iridium shell of about $6.2 \times 10^{-3} \mathrm{~g} / \mathrm{y}$ or $0.002 \mathrm{mil} / \mathrm{y}$, and will not affect FSA operation. The vapor pressures of the gaseous carbon species (Tables A-26, A-27 and A-28) at $1700^{\circ} \mathrm{K}$ are all lower than $1.7 \times 10^{-14} \mathrm{~atm}$, and are too low to have any effect. No Ir-C compound forms at $1700^{\circ} \mathrm{K}$ and the solubiiity of carbon in <Ir $>$ at this temperature (Table A-30) is too low to have any effect.

6. Impurity Effects. Certain impurities could, if present, affect some of the results calculated above. One of the potentially worst situations could arise if the iridium shell contained significant amounts of $<\mathrm{IrO}_{2}>$ prior to being welded around the fuel sphere. The iridium in an FSA shell weighs about $65 \mathrm{~g}$. If the iridium contained 250 ppm of oxygen as $<\mathrm{IrO}_{2}>$ there would be $0.11 \mathrm{~g}$ or $5.1 \mathrm{x}$ $10^{-4}$ inoles of $\left\langle\mathrm{IrO}_{2}\right\rangle$ present. One mole of $\left\langle\mathrm{IrO}_{2}\right\rangle$ decomposes at about $1400^{\circ} \mathrm{K}$ to release $1 \mathrm{~atm}$ of $\left(\mathrm{O}_{2}\right)^{31}$. If ideal gas behavior is followed, $5.1 \times 10^{-4}$ moles of $\left\langle\mathrm{IrO}_{2}\right\rangle$ will produce $5.1 \times 10^{-4} \mathrm{~atm}$ of $\left(\mathrm{O}_{2}\right)$ at $1400^{\circ} \mathrm{K}$. As the temperature increases to $1700^{\circ} \mathrm{K}$, the $\left(\mathrm{O}_{2}\right)$ pressure becomes $(1700 / 1400) \times\left(5.1 \times 10^{-4}\right)=6.2 \times 10^{-4} \mathrm{~atm}$. If this ox:'gen reacts with the iridium shell, the ( $\left.\operatorname{IrO}_{3}\right)$ loss rate, calculated from Eq. (80), becomes $3.5 \times 10^{-7} \mathrm{~g} / \mathrm{cm}^{2} \mathrm{sec}$, a value more than 3800 times that caused by the $\left(\mathrm{O}_{2}\right)$ from the fuel, $\mathrm{Eq}(81)$. In a similar manner, the ( $\left.\mathrm{IrO}_{2}\right)$ loss rate is calculated to be $4.1 \times 10^{-8} \mathrm{~g} / \mathrm{cm}^{2} \mathrm{sec}$, more than 250 times the rate caused by $\left(O_{2}\right)$ from the fuel. It is obvious that the iridium shell material should be treated to reduce the oxygen content prior to encapsulation.

7. Summary. The inpurity levels within the FSA system, especially oxygen in the iridium shell, should be kept as low as possible. If this is accomplished, the thermodynamic stability of a $\left\langle\mathrm{PuO}_{2}\right\rangle-\langle$ Ir $\rangle-\langle$ C $\rangle$ FSA system at $1700^{\circ} \mathrm{K}$ is such that missions could last as long as the half-life of the ${ }^{238} \mathrm{Pu}, 88 \mathrm{y}$. At this temperature the fuel stoichiometry will stabilize between $\left\langle\mathrm{PuO}_{2} \cdot 0\right\rangle$ and $\left.<\mathrm{PuO}_{1} \cdot{ }_{98}\right\rangle$.

The maximum rates at which $\left(\mathrm{O}_{2}\right)$ and $\left(\mathrm{PuO}_{2}\right)$ are given off from the fuel surface are summarized in Table C-2.
These values are calculated assuming the fuel to be $\left\langle\mathrm{PuO}_{2} \cdot 0\right.$. Also summarized in Table $\mathrm{C}-2$ are maximum generation rates for $\left(\mathrm{IrO}_{3}\right)$ and $\left(\mathrm{IrO}_{2}\right)$ at the inner surface of the iridium shell. These values are calculated assuming that all of the oxygen comes from $\left\langle\mathrm{PuO}_{2} \cdot{ }_{0}\right\rangle$ fuel. The presence of any impurities such as $<\mathrm{IrO}_{2}>$ would cause these values to increase.

The maximum rates at which $\left(\mathrm{O}_{2}\right),\left(\mathrm{PuO}_{2}\right),\left(\mathrm{IrO}_{3}\right)$ and $\left(\mathrm{IrO}_{2}\right)$ can effuse out the vents are summarized in Table C-3. No vent covers are considered and the fuel was assumed to be $\left\langle\mathrm{PuO}_{2} \cdot 0\right\rangle$. No impurity effects were considered.

\section{C. $1800^{\circ} \mathrm{K}$}

If the maximum operating temperature of the fuel sphere is increased to $1800^{\circ} \mathrm{K}$ the partial pressures within the system, especially that of $\left(\mathrm{O}_{2}\right)$, will increase significantly. The following discussion illustrates the effect on FSA operation.

1. Oxygen. The values listed in Table A-9 indicate that at $1800^{\circ} \mathrm{K}$, the predominate vapor species above $<\mathrm{PuO}_{2} \cdot \mathrm{O}$ is $\left(\mathrm{O}_{2}\right)$ with a partial pressure of $2.8 \times 10^{-4} \mathrm{~atm}$ This value, combined with the Langmuir equation, yields an $\left(\mathrm{O}_{2}\right)$ loss rate of

$$
\mathrm{Z}_{\mathrm{O}_{2}}=1.7 \times 10^{-3} \mathrm{~g} / \mathrm{cm}^{2} \mathrm{sec} \text {. }
$$

The total sphere surface area at $1800^{\circ} \mathrm{K}$ is $45.0 \mathrm{~cm}^{2}$ (Table $C-1)$ so that the total $\left(\mathrm{O}_{2}\right)$ loss rate from the sphere is

$$
\mathrm{Z}_{\mathrm{O}_{2}}=7.5 \times 10^{-2} \mathrm{~g} / \mathrm{sec} \text {. }
$$

This rate is about 110 times that calculated for $1700^{\circ} \mathrm{K}$, [Eq. (75)].

a. Fuel Reduction. In order for the fuel to be reduced from $\left.\left\langle\mathrm{PuO}_{2} \cdot\right\rangle_{0}\right\rangle$ to $\left\langle\mathrm{PuO}_{1} \cdot{ }_{98}\right\rangle$, a total of $0.3 \mathrm{~g}$ of oxygen must be removed. The minimum time for this to occur, based on Eq. (90), is 4 sec.

Once the fuel is reduced to $\left\langle\mathrm{PuO}_{1} \cdot{ }_{98}\right\rangle$, the $\left(O_{2}\right)$ pressure becomes $2.6 \times 10^{-9}$ atm (Table A-10) and the loss rate of $\left(\mathrm{O}_{2}\right)$ from the sphere becomes

$$
\mathrm{Z}_{\mathrm{O}_{2}}=6.9 \times 10^{-7} \mathrm{~g} / \mathrm{sec} \text {. }
$$

The minimum time required to reduce $\left\langle\mathrm{PuO}_{1} \cdot 98\right\rangle$ to $\left\langle\mathrm{PuO}_{1} \cdot 95\right\rangle$ through evaporation of $\left(\mathrm{O}_{2}\right)$ from the sphere, i.e., to remove $0.45 \mathrm{~g}$ of oxygen is about $7.5 \mathrm{~d}$. 
Once the fuel is reduced to $\left\langle\mathrm{PuO}_{1} \cdot 95\right\rangle$, the $\left(\mathrm{O}_{2}\right)$ pressure becomes $2.5 \times 10^{-10} \mathrm{~atm}($ Table $A-11)$ and the $\left(O_{2}\right)$ loss rate becomes

$$
\mathrm{Z}_{\mathrm{O}_{2}}=6.7 \times 10^{-8} \mathrm{~g} / \mathrm{sec} \text {. }
$$

In order for the sphere to be reduced from 0.93 moles of $\left\langle\mathrm{PuO}_{1} \cdot 95\right\rangle$ to 0.93 moles of $\left\langle\mathrm{PuO}_{1} \cdot{ }_{92}\right\rangle, 0.93 \times 0.03 \times 16=$ $0.45 \mathrm{~g}$ of oxygen must be removed. The minimum time required for this to occur, based on Eq. (92), is $78 \mathrm{~d}$.

In a similar manner, the minimum time required for the sphere to be reduced from $\left\langle\mathrm{PuO}_{1} \cdot{ }_{92}\right\rangle$ to $\left\langle\mathrm{PuO}_{1} \cdot{ }_{90}\right\rangle$ is calculated to be $1.8 \mathrm{y}$. Thus, when the operating temperature is increased from $1700^{\circ} \mathrm{K}$ to $1800^{\circ} \mathrm{K}$ there is a much greater tendency for the fuel to be reduced. The actual stoichiometry of the fuel will depend primarily on the $\left(O_{2}\right)$ effusion rate through the vents.

\section{b. Effusion of $\left(O_{0}\right)$ from the FSA. If the solld}

fuel composition is $\left\langle\mathrm{PuO}_{2}\right\rangle$, the $\left(\mathrm{O}_{2}\right)$ partial pressure will be $2.8 \times 10^{-4} \mathrm{~atm}$, and the maximum amount of $\left(\mathrm{O}_{2}\right)$ that will effuse out the vents is

$$
w_{O_{2}}=9.2 \times 10^{-9} \mathrm{~g} / \mathrm{sec} \text {. }
$$

The time required to remove $0.3 \mathrm{~g}$ of oxygen so that the fuel is reduced from $\left\langle\mathrm{PuO}_{2}\right\rangle$ to $\left\langle\mathrm{PuO}_{1} \cdot \mathrm{gs}\right\rangle$ is about $1 \mathrm{y}$. Likewise, the time required to sffuse $0.45 \mathrm{~g}$ of oxygen from the FSA, so that the fuel is reciuiced from $\left\langle\mathrm{PuO}_{1} \cdot{ }_{98}\right\rangle$ to $\left\langle\mathrm{PuO}_{1} \cdot{ }_{95}\right\rangle$ is $1.7 \times 10^{5} \mathrm{y}$. Thus, the fuel stoichiometry will stabllize at approximately $\left\langle\mathrm{PuO}_{1} \cdot 98\right\rangle$.

\section{c. Effect of 10 . The partial pressure of $(0)$} above $\left\langle\mathrm{PuO}_{2}\right\rangle$ at $1800^{\circ} \mathrm{K}$ is $2.0 \times 10^{-6} \mathrm{~atm}$. The maximum loss rate from the sphere surface is

$$
\mathrm{Z}_{\mathrm{O}}=3.8 \times 10^{-4} \mathrm{~g} / \mathrm{sec} \text {. }
$$

When this value is compared with the $\left(O_{2}\right)$ loss rate given by Eq $(90)$, the $(O)$ contribution to the total oxygen loss rate is found to be $0.5 \%$ that from $\left(\mathrm{O}_{2}\right)$.

\section{d. Effect of Helium. The (He) generation}

rate was calculated above in section $B$ to be $1.1 \times 10^{14}$ atoms/sec. The $\left(O_{2}\right)$ loss rate given by Eq. (90) corresponds to $1.4 \times 10^{21}$ molecules/sec or about $10^{7}\left(O_{2}\right)$ molecules per ( $\mathrm{He}$ ) atom. The (He) generation should have little effect.

\section{e. Reactions with the Iridium Shell. The free} energy for the reaction between $\left\langle\mathrm{Ir}>\right.$ and $\left(\mathrm{O}_{2}\right)$ to form $\left(\mathrm{IrO}_{3}\right), \mathrm{Eq} .(79)$, is $23.37 \mathrm{kcal} / \mathrm{mole}$ at $1800^{\circ} \mathrm{K}$. Above $<\mathrm{PuO}_{2}>$ fuel the $\left(\mathrm{O}_{2}\right)$ partial pressure is $2.8 \times 10^{-4} \mathrm{~atm}$ and the ( $\mathrm{IrO}_{3}$ ) partial pressure is calculated to be $6.8 \times 10^{-9}$

atm. This value leads to an $\left(\mathrm{IrO}_{3}\right)$ loss rate of

$$
\mathrm{Z}_{\mathrm{IrO}_{3}}=1.1 \times 10^{-7} \mathrm{~g} / \mathrm{cm}^{2} \mathrm{sec} \text {, }
$$

or from the entire inner surface of the iridium shell

$$
\mathrm{Z}_{\mathrm{IrO}_{\mathrm{S}}}=5.4 \times 10^{-6} \mathrm{~g} / \mathrm{sec} \text {. }
$$

This ( $\left.\mathrm{IrO}_{3}\right)$ generation rate will not consume sufficient $\left(\mathrm{O}_{2}\right)$ to affect the loss of $\left(\mathrm{O}_{2}\right)$ from the fuel surface. However, this rate is about 990 times that caused by reaction with $\left(O_{2}\right)$ from the fuel at $1700^{\circ} \mathrm{K}$, [Eq. (82)]

The ( $\mathrm{IrO}_{3}$ ) generation rate given by Eq. (95) corresponds to an Ifidium loss of about $49 \mathrm{mil} / \mathrm{y}$. This value is calcuiated for the worst case, assuming the fuel remains $\left.<\mathrm{PuO}_{2}\right\rangle$. Actually, as noted above, the fuel will be rather quickly reduced to about $\left\langle\mathrm{PuO}_{1} \cdot \mathrm{g}_{8}\right\rangle$. Thus the corresponding $\left(O_{2}\right)$ and $\left(I r O_{j}\right)$ partial pressures will be lowered. Nevertheless, an FSA operated at $1800^{\circ} \mathrm{K}$ will have a shortsr useful mission lifetime than it would operated at $1700^{\circ} \mathrm{K}$.

The free energy of formation for ( $\left.\mathrm{IrO}_{2}\right)$ at $1800^{\circ} \mathrm{K}$ is $41.87 \mathrm{kcal} / \mathrm{mole}$. Above $\left\langle\mathrm{PuO}_{2}\right\rangle$ the $\left(\mathrm{O}_{2}\right)$ partial pressure is $2.8 \times 10^{-4}$ atm and the ( IrO $_{2}$ ) partial pressure is calculated to be $2.6 \times 10^{-9} \mathrm{~atm}$. This corresponds to a loss rate from the inner shell surface of

$$
\mathrm{Z}_{\mathrm{IrO}_{2}}=2.0 \times 10^{-6} \mathrm{~g} / \mathrm{sec}
$$

or about $19 \mathrm{mil} / \mathrm{y}$ of iridium. Again, this is a value calculated for the worst case and the ( $\mathrm{IrO}_{2}$ ) generation rate will decrease as the fuel is reduced to $\left\langle\mathrm{PuO}_{1} \cdot 98\right\rangle$. Note however, that the value given $\mathrm{EI} \mathrm{Eq.} \mathrm{(97)} \mathrm{for} \mathrm{the} \mathrm{genera-}$ tion rate of ( $\left.\mathrm{IrO}_{2}\right)$ is more than 200 times the value calculated at $1700^{\circ} \mathrm{K},[$ Eq. (86)] .

2. $\left(\mathrm{PuO}_{2}\right)$. The equilibrium partial pressure of $\left(\mathrm{PuO}_{2}\right)$ above $\left\langle\mathrm{PuO}_{2}\right\rangle$ at $1800^{\circ} \mathrm{K}$ is $2.0 \times 10^{-9}$ atm (Table $\mathrm{A}-9$ ). The maximum loss rate from a fuel sphere, with a surface area of $45.0 \mathrm{~cm}^{2}$ ( Table C-11), is

$$
\mathrm{Z}_{\mathrm{PuO}_{2}}=1.5 \times 10^{-6} \mathrm{~g} / \mathrm{sec} \text {. }
$$

This value is about 9 times greater than that calculated at $1700^{\circ} \mathrm{K}[\mathrm{Eq} .(88)]$. 
If the fuel remained $<\mathrm{PuO}_{2}>$ indefinitely the sphere could lose up to $47 \mathrm{~g}$ ( $\mathrm{PuO}_{2}$ ) per $\mathrm{y}$, with a resultant maximum deposit of $\left\langle\mathrm{PuO}_{2}\right\rangle$ on the iridium shell of $1 \mathrm{mil} / \mathrm{y}$. However, the maximum effusion rate of ( $\mathrm{PuO}$ ) through the vents is calculated to be only $6 \times 10^{-6} \mathrm{~g} / \mathrm{y}$. In addition, the $\left(\mathrm{PuO}_{2}\right)$ partial pressure will decrease as the fuel is reduced to $\left\langle\mathrm{PuO}_{1} \cdot \mathrm{gB}_{\mathrm{B}}\right\rangle$. It is unlikely that at $1800^{\circ} \mathrm{K}$, vaporization of $\left(\mathrm{PuO}_{2}\right)$ will seriously affect FSA operation.

3. (PuO). The equilibrium partial pressure of ( $P u O$ ) above $\left\langle\mathrm{PuO}_{2}\right\rangle$ at $1800^{\circ} \mathrm{K}$ is $2,9 \times 10^{-14}$ atro (Table A-9). This corresponds to a maximum loss rate from the sphere surface of $7.4 \times 10^{-4} \mathrm{~g} / \mathrm{y}$ and a maximum effusion through the vents of $6 \times 10^{-10} \mathrm{~g} / \mathrm{y}$. Neither will affect FSA operation.

4. (Pu). The equilibrium partial pressure of ( $\mathrm{Pu}$ ) above $\left\langle\mathrm{PuO}_{2}\right\rangle$ at $1800^{\circ} \mathrm{K}$ is $1.9 \times 10^{-25}$ aim (Table A-9). This corresponds to a maximum loss rate from the sphere surface of $4 \times 10^{-13} \mathrm{~g} / \mathrm{y}$ and a maximum effusion through the vents of $5 \times 10^{-20} \mathrm{~g} / \mathrm{y}$. FSA operation will not be affected. The partial pressure of ( $\mathrm{Pu}$ ) will be too low for the formation of $\left\langle\right.$ PuI $_{2}>$ unless the fuel is reduced to $\left\langle\mathrm{PuO}_{1} \cdot \mathrm{7}\right\rangle$. The oxygen results discussed above indicate that the fuel should not be reduced below $\left\langle\mathrm{PuO}_{1} \cdot 9_{8}\right\rangle$.

5. Iridium-Carbon. No Ir-C compound will form and the solubility of $\langle\mathrm{C}\rangle$ in $\langle$ Ir $\rangle$ at $1800^{C_{K}}$ is very low (Table A-30). The vapor pressures of (Ir), 3.4 $\times 10^{-12}$ atm, and the various ( $C_{X}$ ) species, all below $3 \times 10^{-13} \mathrm{~atm}$, are too low to have any appreciable effect.

\section{Impurity Effects. The same general comments} apply as discussed above for operation at $1700^{\circ} \mathrm{K}$, except that the effects of impurities such as $\left\langle\mathrm{IrO}_{2}\right\rangle$ will be more deleterious at the higher temperature.

7. Sunmary. Considering only the thermochemical stability within the $\left.\left.\left\langle\mathrm{P}_{1} \mathrm{O}_{2}\right\rangle-<\mathrm{Ir}\right\rangle-<\mathrm{C}\right\rangle$ system, an FSA could probably be operated at $1800^{\circ} \mathrm{K}$. However, the vaporization of $\left(\mathrm{O}_{2}\right)$ from the fuel and the generation of ( $\left(\mathrm{IO}_{3}\right)$ and ( $\left.\mathrm{IrO}_{2}\right)$ at the walls of the iridium shell would be greater than at $1700^{\circ} \mathrm{K}$. This would lead to a shorter mission lifetime. In addition, if the FSA is to operate at $1800^{\circ} \mathrm{K}$, impurities such as $<\mathrm{IrO}_{z}>$ must be kept at lower levels than for $1700^{\circ} \mathrm{K}$ operation. Accordingly, FSA operating temperatures below $1750^{\circ} \mathrm{K}\left(1480^{\circ} \mathrm{C}\right)$ would seem to be recort.mended.

Maximum generation rates for $\left(\mathrm{O}_{2}\right),\left(\mathrm{PuO}_{2}\right),\left(\mathrm{IrO}_{3}\right)$ and $\left(\mathrm{IrO}_{2}\right)$ are summarized in Table $\mathrm{C}-2$. Maximum effusion rates for these species through the FSA vents are summarized in Table $\mathrm{C}-3$. In each case the fuel was assumed to be $\left\langle\mathrm{PuO}_{2} .0\right\rangle$ and no impurity effects were considered.

D. $1600^{\circ} \mathrm{K}$

The equilibrium partial pressures above $\left\langle\mathrm{PuO}_{2} \cdot 0\right\rangle$ at $1600^{\circ} \mathrm{K}$ are listed in Table $\mathrm{A}-9$ as $\mathrm{P}_{\mathrm{O}_{2}}=1.2 \times 10^{-8} \mathrm{~atm}$ $\mathrm{P}_{\mathrm{PuO}_{2}}=1.7 \times 10^{.11} \mathrm{~atm}, \mathrm{P}_{\mathrm{PuO}}=2.0 \times 10^{-15} \mathrm{~atm}$ and $P_{\mathrm{Pu}_{\mathrm{u}}}=4.5 \times 10^{-24} \mathrm{~atm}$. These values are considerably lower than at $1700^{\circ} \mathrm{K}$ and usefur FSA lifetime would be extended accordingly.

1. Oxygen. An $\left(\mathrm{O}_{2}\right)$ partial pressure above $\left\langle\mathrm{PuO}_{2.0}\right\rangle$ of $1.2 \times 10^{-8} \mathrm{~atm}$ corresponds to a loss rate from the sphere of

$$
\mathrm{z}_{\mathrm{O}_{2}}=7.5 \times 10^{-6} \mathrm{~g} / \mathrm{cm}^{2} \mathrm{sec}
$$

At $1600^{\circ} \mathrm{K}$, the sphere surface area is $44.76 \mathrm{~cm}^{2}$ (Table $C-1)$ so that the to:al $\left(O_{2}\right)$ generation rate becomes

$$
\mathrm{z}_{\mathrm{O}_{2}}=3.4 \times 1 \mathrm{~g}^{-6} \mathrm{~g} / \mathrm{sec} \text {. }
$$

This rate is 200 times lower than that given by Eq. (75) for $1700^{\circ} \mathrm{K}$.

a. Fuel Reduction. In order for the fuel to be reduced from $\left\langle\mathrm{PuO}_{2 \cdot 0}\right\rangle$ to $\left\langle\mathrm{PuO}_{1} \cdot 9 \mathrm{~g}\right\rangle, 0.3 \mathrm{~g}$ of oxygen must be removed from a sphere containing 0.93 moles $\left.<\mathrm{PuO}_{2} \cdot 0\right\rangle$. The minimum time required for this to occur is calculated from Eq. $(100)$ to be 2.6d. The rate at which $\left(O_{2}\right)$ with a partial pressure of $1.2 \times 10^{-8}$ atm can effuse through the vents is

$$
\mathrm{w}_{\mathrm{O}_{2}}=4.1 \times 10^{-13} \mathrm{~g} / \mathrm{sec} \text {. }
$$

Thus, it would require $2.3 \times 10^{5}$ y to remove $0.3 \mathrm{~g}$ of $\left(\mathrm{O}_{2}\right)$ from the FSA and the $\left(\mathrm{O}_{2}\right)$ overpressure would maintain the fuel at a stoichiometry near $\left\langle\mathrm{PuO}_{2} \cdot \mathrm{O}\right\rangle$.

\section{b. Effect of $(O)$. The partial pressure of $(0)$} corresponding to an $\left(\mathrm{O}_{2}\right)$ partial pressure of $1.2 \times 10^{-8} \mathrm{~atm}$ is $1.4 \times 10^{-9} \mathrm{~atm}$. This leads to an (O) loss rate from the sphere surface of

$$
\mathrm{z}_{\mathrm{O}}=3.2 \times 10^{-7} \mathrm{~g} / \mathrm{sec} \text {. }
$$


Thus, the $(0)$ generation rate contributes about $9 \%$ of the total uxygen loss from the sphere. The maximum rate at which $(O)$ can effuse through the vents is

$$
w_{O}=4.8 \times 10^{-14} \mathrm{~g} / \mathrm{sec} \text {. }
$$

It would take $2.5 \times 10^{5} y$ for $0.3 \mathrm{~g}$ of oxygen to escape the FSA as (O) and the generation of $(O)$ will have litule effect on the fuel stoichiometry.

\section{c. Effect of Helium. The hellum generation} rate, calculated above in section $B$, is $i .1 \times 10^{14}$ atoms/ sec. The $\left(\mathrm{O}_{2}\right)$ generation rate given by $\mathrm{Eq}$. $(100)$ corresponds to $6.4 \times 10^{16} \mathrm{molecules} / \mathrm{sec}$ so that the effect of (Ye) would be to add about $0.2 \%$ to the rate at which oxygen effuses out of the FSA.

\section{d. Reactions with the Iridium Shell. The free} energy of formation of $\left(1 \mathrm{rO}_{3}\right)$ at $1600^{\circ} \mathrm{K}$ is calculated from Eqs. (42), (43) and (44) to be $21.25 \mathrm{kcal} / \mathrm{mole}$. This value, combined with an $\left(O_{2}\right)$ partial pressure of $1.2 \times 10^{-8}$ atm, leads to a maximum ( $\mathrm{IrO}_{3}$ ) partial pressure of $1.6 \mathrm{x}$ $10^{-15} \mathrm{~atm}$. This value corresponds to an (IrO) loss rate of

$$
\mathrm{Z}_{\mathrm{IrO}_{5}}=2.8 \times 10^{-14} \mathrm{~g} / \mathrm{cm}^{2} \mathrm{sec}
$$

or, for an inner shell area of $49.3 \mathrm{~cm}^{2}$

$$
\mathrm{Z}_{\mathrm{IrO}_{3}}=1.4 \times 10^{-12} \mathrm{~g} / \mathrm{sec} .
$$

This ( $\left(\mathrm{rO}_{3}\right)$ generation rate is more than 3000 times lower than that given by Eg. (82) for $1700^{\circ} \mathrm{K}$ and will not affect the rate at which $\left(O_{\text {y }}\right)$ leaves the sphere surface. The maximum <Ir> recession rate is calculated to be $1.2 \mathrm{x}$ $10^{-5} \mathrm{mil} / \mathrm{y}$.

The free energy of formation for $\left\langle\mathrm{IrO}_{2}\right\rangle$ at $1600^{\circ} \mathrm{K}$, given by Eg. ( 49 ) is $42.26 \mathrm{kcal} / \mathrm{mole}$. Given an $\left(O_{2}\right)$ pressure of $1.2 \times 10^{-8} \mathrm{~atm}$, the maximum ( $\mathrm{IrO}_{2}$ ) partial pressure is calculated to be $2.0 \times 10^{-14} \mathrm{~atm}$. The maximum rate loss is

$$
\mathrm{Z}_{\mathrm{IrO}_{2}}=1.6 \times 10^{-11} \mathrm{~g} / \mathrm{sec} \text {. }
$$

This value corresponds to a maximum <Ir> recession rate of $1.6 \times 10^{-4} \mathrm{mil} / \mathrm{y}$.

2. $\left(\mathrm{PuO}_{2}\right)$. The maximum calculated loss rate of $\left(\mathrm{PuO}_{2}\right)$ from the sphere surface is

$$
\mathrm{Z}_{\mathrm{PuO}_{2}}=1.4 \times 10^{-8} \mathrm{~g} / \mathrm{sec} \text {. }
$$

This corresponds to only $0.4 \mathrm{~g} / \mathrm{y}$. The maximum loss rate of $\left(\mathrm{PuO}_{2}\right)$ through the vents is calculatei to be $5.3 \mathrm{x}$ $1 n^{-8} \mathrm{~g} / \mathrm{y}$. Vaporization of $\left(\mathrm{PuO}_{2}\right)$ at $1600^{\circ} \mathrm{K}$ will not affect FSA operation.

3. (PuO). The maximum loss rate for (PuO) from the sphere surface is calculated to be

$$
z_{\text {PuO }}=1.6 \times 10^{-12} \mathrm{~g} / \mathrm{sec} \text {. }
$$

This corre zponds to $5 \times 10^{-5} \mathrm{~g} / \mathrm{y}$. The maximum rate at which (PuO) can effuse out the vents is $5.8 \times 10^{-12} \mathrm{~g} / \mathrm{y}$. FSA operation will not be affected.

4. (Pui). The maximum ( $P u$ ) loss rate from the fuel sphere is

$$
Z_{\text {Pu }}=3.4 \times 10^{-21} \mathrm{~g} / \mathrm{sec} \text {. }
$$

This corresponds to $1.1 \times 10^{-13} \mathrm{~g} / \mathrm{y}$. The maximum rate at which ( $P u$ ) can effuse through the vents is $3 \times 10^{-22} \mathrm{~g} / \mathrm{y}$. The vapor pressure of ( $\mathrm{P} \psi$ ) above $\left\langle\mathrm{PuIr}_{2}\right\rangle$ at $1600^{\circ} \mathrm{K}$ is calculated from Eq. (48) to be $4.8 \times 10^{-13} \mathrm{~atm}$. In order for the ( $P(4)$ partial pressure above the fitel to to inigh enough to overcome this, the fuel would have to be reduced to $\left\langle\mathrm{FuO}_{1} \cdot \mathrm{r0}_{0}\right\rangle($ Table A-17). Vaporization of (Pu) at $1600^{\circ} \mathrm{K}$ will not affect FSA operation.

5. Iridium-Caroon. At $1600^{\circ} \mathrm{K}$, the vapor pressure of (Ir) above <Ir> is glven by Eq. (32) as $1.5 \times 10^{-14} \mathrm{~atm}$. The vapor pressures of the various ( $C_{X}$ ) species (Tables $A-26, A-27$ and $A-28$ ) are all less then $3 \times 10^{-16}$ atm. None of these will affect FSA operation.

6. Impurity Effects. Although the effects of impurities will be less deleterious at $1600^{\circ} \mathrm{K}$ than at $1700^{\circ} \mathrm{K}$, it is still necessary to maintain the amounts of impurities such as < $\left\langle\mathrm{IrO}_{2}>\right.$ at low levels. For example, if the iridium shell contains only $100 \mathrm{ppm}$ oxygen as $\left\langle\mathrm{IrO}_{2}\right\rangle$, the generation rate of ( $\left.\operatorname{IrO}_{3}\right)$ at $1600^{\circ} \mathrm{K}$ will be about $10^{6}$ times greater than that given by Eg. (104).

7. Summary. Provided that the fuel, iridium and graphite are of high purit;, an FSA should function satisfactorily at any temperature in the range $1600-1750^{\circ} \mathrm{K}$. The maximum rates at which significant vapor species are generated from the surfaces of the sphere or iridium shell are summarized in Table C-2. Maximum rates of effusion through the vents are summarized in Table C-3. 


\section{E. Reentry}

Current reentry calculations project a $5 \mathrm{~min}$ thermal excursion for the FSA. The fuel surface temperature increases from the operational temperature to a maximum value in the range $2000-2200^{\circ} \mathrm{K}$. Further, it is predicted that this reentry will produce a temperature gradient of uj to $200^{\circ} \mathrm{C}$ across an ISA.

F. Reenticy at $2000^{\circ} \mathrm{K}$ if the Fuel is $\left\langle\mathrm{PuO}_{2} \div 0^{\circ}\right\rangle$

The "worst case" situation at reentry would be for the fuel to ccnsist of $\left\langle\mathrm{PuO}_{2} \cdot 0\right\rangle$ as this would lead to a maximum $\left(\mathrm{O}_{2}\right)$ partial pressure and hence maximum reaction with the iridium sheil.

1. Oxygen. The equilibrium partial pressure of $\left(O_{2}\right)$ above $\left\langle\mathrm{PuO}_{2} 0_{0}\right.$ a $2000^{\circ} \mathrm{K}$ is 0.87 atm (Table A-9). This leads to a maximum loss of $\left(\mathrm{O}_{2}\right)$ from the fuel of

$$
\mathrm{z}_{\mathrm{O}_{2}}=4.9 \mathrm{~g} / \mathrm{cm}^{2} \mathrm{sec} \text {. }
$$

At $2000^{\circ} \mathrm{K}$, the surface area for a 100 watt sphere is given in Table C- 1 to be $45.18 \mathrm{~cm}^{2}$ so that the loss rate becomes

$$
\mathrm{Z}_{\mathrm{O}_{2}}=220.3 \mathrm{~g} / \mathrm{sec} \text {. }
$$

The time required to remove $0.3 \mathrm{~g}$ of oxygen from the sphere and reduce the fuel from $\left.\left\langle\mathrm{PuO}_{2} \cdot\right\rangle\right\rangle$ to $\left\langle\mathrm{PuO}_{1} \cdot \mathrm{sg}\right\rangle$ is only $1.4 \times 10^{-4} \mathrm{sec}$. The maximum rate at which $\left(O_{2}\right)$ at a partial pressure of 0.87 atro could effuse through the vents is

$$
{ }^{w_{O_{2}}}=2.6 \times 10^{-5} \mathrm{~g} / \mathrm{sec} \text {. }
$$

Thus, it would take $3.2 \mathrm{~h}$ to remove $0.3 \mathrm{~g}$ of oxygen from the FSA and the $\left(\mathrm{O}_{2}\right)$ over pressure would prevent further reduction of the fuel. Thus, during the $5 \mathrm{~min}$ reentry, $0.3 \mathrm{~g}$ of oxygen could be removed from the sphere produci.ig $\left\langle\mathrm{PuO}_{1} \cdot{ }_{08}\right\rangle$, but only $0.008 \mathrm{~g}$ of oxygen couid come out the vents.

2. Effect oI (O). The equilibrium partial pressure of $(O)$, corresponding to an $\left(O_{2}\right)$ partlal pressure of 0.87 $\mathrm{atm}$, is $6.2 \times 10^{-4} \mathrm{~atm}$. The maximum calculated rate loss of $(O)$ from the sphere surface is

$$
\mathrm{Z}_{\mathrm{O}}=0.11 \mathrm{~g} / \mathrm{sec} \text {, }
$$

a value that is only $0.05 \%$ of that given by Eq. (111) for $\left(\mathrm{O}_{2}\right)$. In $5 \mathrm{~min}, 4 \times 10^{-6} \mathrm{~g}$ of oxygen in the form of $(\mathrm{O})$ could escape through the vents.
3. Effect of llelfum. The (fic) generation rate mas calculated above in section $\mathrm{B}$ to be $1.1 \times 10^{1 / 4}$ atoms/sec. The $\left(\mathrm{O}_{2}\right)$ generation rate given by EQ. (111) corresponds to $4.1 \times 10^{24}$ molecules/sec, 1.c., $10^{10}\left(\mathrm{O}_{2}\right)$ molecules per (He) atom. Gencration of (He) will not affect the generation of $\left(\mathrm{O}_{2}\right)$. While a large ( $\mathrm{He}$ ) inventory present at the time of reentry would suppress the generation of $\left(\mathrm{O}_{2}\right)$ somewhat, experiments conducted at LASL predtct little retention of heliuns at the operating temperatures, 1600$1800^{\circ} \mathrm{K}$. If the FSA's are degassed prior to launch, there will te no appreciable hellum inventory in the event of an immediate reentry should the capsule not achicve orbit.

4. Reactions with the Iridium Shell. The free energ $y$ of formation of ( $\left(\mathrm{rO}_{3}\right)$ at $2000^{\circ} \mathrm{K}$, calculated from Eqs. (42) (43) and (44), is $25.49 \mathrm{kcal} / \mathrm{mole}$. The maximum parial pressure of $\left(\mathrm{IrO}_{3}\right)$ is calculated to be $1.3 \times 10^{-3} \mathrm{~atm}$. This leads to a maximum generation rate of

$$
\mathrm{Z}_{\mathrm{IrO}_{3}}=0.02 \mathrm{~g} / \mathrm{cm}^{2} \mathrm{sec}
$$

or, for the entire iridium shell,

$$
\mathrm{Z}_{\mathrm{IrO}_{3}}=1 \mathrm{~g} / \mathrm{sec} \text {. }
$$

The $\left(\mathrm{IrO}_{3}\right)$ generation rate given by Eq. (114) predicts a maximum iridium loss of $86 \mathrm{mil}$ in $5 \mathrm{~min}$. The maximum rate at which ( $\mathrm{IrO}_{3}$ ) could effuse through the vents is $3.2 \mathrm{x}$ $10^{-5} \mathrm{~g}$ in $5 \mathrm{~min}$. These, however, are mardimum values, based on a $300^{\circ} \mathrm{C}$ extrapolation of the transpiration date, and undoubtedly are much too large. The $\left(\mathrm{O}_{2}\right) /\left(\mathrm{IrO}_{3}\right)$ partial pressure ratio is 670 and the $\left(O_{2}\right)$ overpressure would inhibit the loss of ( $\mathrm{IrO}_{3}$ ) from the fridium shell. If the Rice kinetic data ${ }^{35,37}$ are extrapolated to an $\left(\mathrm{O}_{2}\right)$ pressure of $0.87 \mathrm{~atm}$, the predicted iridium loss is $3 \mathrm{mil}$ in $5 \mathrm{~min}$. Further indication that these maximum values are too high comes from compatibility experiments conducted at LASL. 57 In these experiments, $\left\langle\mathrm{PuO}_{2} .9\right\rangle$ was heated in an Iridium capsule for $30 \mathrm{~min}$, at about $2200^{\circ} \mathrm{K}\left(1927^{\circ} \mathrm{C}\right)$ with no deleterious effects. Finally, Battles et al., heated $<\mathrm{PuO}_{2} \cdot 0>$ in an iridium Knudsen cell and observed no Ir-O species at $2000^{\circ} \mathrm{K}$.

The free energy of formation for ( $\left.\mathrm{IrO}_{2}\right)$ is calculated from Eq. (40) to be $40.70 \mathrm{kcal} / \mathrm{mole}$. From this, the maximum partial pressure is calculated to be $3.1 \times 10^{-5}$ atm from which the loss rate is calculated to be

$$
\mathrm{Z}_{\mathrm{IrO}_{2}}=0.023 \mathrm{~g} / \mathrm{sec} \text {. }
$$


This corresponds to a loss of $2 \mathrm{mil}$ of irldium in $5 \mathrm{~min}$. The maxinum arrount of $\left(1 \mathrm{HO}_{2}\right)$ that could effuse through the vents in $5 \mathrm{~min}$. Is $7.5 \times 10^{-i} \mathrm{~g}$. As for the ense of $\left(\mathrm{IrO}_{3}\right)$ these calculated maximum values are tos high.

5. (PuO ). The maximum rate at which $\left(\mathrm{PuO}_{2}\right)$ could leave the surface of a $\left\langle\mathrm{PuO}_{2} .0^{\circ}\right.$ sphere at $2000^{\circ} \mathrm{K}$ is

$$
\mathrm{Z}_{\mathrm{PuO}_{3}}=7.2 \times 10^{-5} \mathrm{~g} / \mathrm{scc} \text {. }
$$

This valuc leads to a maximum transport of $0.02 \mathrm{~g}$ of ( $P u O_{2}$ in 5 mist. The maximum amount that could effuse out the rents in $5 \mathrm{~min}$ is $2.6 \times 10^{-9} \mathrm{~g}$. Vaporization of $\left(\mathrm{PuO}_{2}\right)$ will not affect successful reentry of the FSA.

6. (FuO). The maximum rate at which (PuO) could leave the surface of the fuel spherc is $5.1 \times 10^{-8} \mathrm{~g}$ in 5 min. The maximum amount that could effuse through the vents in $5 \mathrm{~min}$ is $6.1 \times 10^{-15} \mathrm{~g}$. FSA reentry will not be affected.

\section{7. $(P U)$. The maximum amount of ( $P w$ that could} leave the fuel surface in $5 \mathrm{~min}$ is $1.3 \times 10^{-17} \mathrm{~g}$. The maximum amount that could escape through the vents is $1.6 \times 10^{-24} \mathrm{~g}$. Reentry of the FSA would not be affected. The fuel would not be sufficiently reduced for the ( $\mathrm{Pu}$ ) partial pressure to become high enough to allow formation of $\left\langle\right.$ PuIr $\left._{2}\right\rangle$.

3. Iridium. The vapor pressure of (Ir) at $2000^{\circ} \mathrm{K}$ is calculated from $\mathrm{Eq} .(32)$ to be $2.5 \times 10^{-10} \mathrm{~atm}$. The max imum loss of iridium due to vaporization uiuring reentry would be $9 \times 10^{-4} \mathrm{mil}$.

9. Impurity Effects. If the system initially contained oxide impurities such as $\left.<\mathrm{IrO}_{2}\right\rangle$, reactions at the operating temperatures discussed previously would lessen the ability of the FSA to survive reentry.

10. Reentry at $2000^{\circ} \mathrm{K}$ if the Fuel is $\left\langle\mathrm{PuO}_{1} \cdot 98\right\rangle$. The calculations performed above for FSA's operating in the range $1600-2000^{\circ} \mathrm{K}$, indicate that except for the case of immediate reentry due to fallure to achieve orbit, the fuel that reenters will be reduced somewhat. If the fuel is reduced to $\left\langle\mathrm{PuO}_{1} \cdot 98\right\rangle$, the equilibrium partial pressure of $\left(\mathrm{O}_{2}\right)$ at $2000^{\circ} \mathrm{K}$ becomes $2.2 \times 10^{-6}$ atm (Table A-10) . The maximum loss rate of $\left(O_{2}\right)$ is calculated to be

$$
\mathrm{Z}_{\mathrm{O}_{2}}=5.6 \times 10^{-4} \mathrm{~g} / \mathrm{sec}
$$

or $0.17 \mathrm{~g}$ in $5 \mathrm{~min}$. This would lead to a reduction of the fuel from $\left\langle\mathrm{PuO}_{1} \cdot \mathrm{gs}\right\rangle$ to $\left\langle\mathrm{PuO}_{1} \cdot 97\right\rangle$. The amount of oxygen as $\left(\mathrm{O}_{2}\right)$, that could escape through the vents in $\mathbf{5} \mathrm{min}$ is only $2 \times 10^{-8} \mathrm{~g}$. Thus, the fuel stoichiometry would remain at $\left\langle\mathrm{PuO}_{1} \cdot \mathrm{9g}\right\rangle$ through reentry.

The maximum amount of ( $\left.\mathrm{ISO}_{3}\right)$ that could be generated in $5 \mathrm{~min}$ is $1.2 \times 10^{-6} \mathrm{~g}$, corresponding to $2 \times 10^{-7} \mathrm{mil}$. The calculated ratio of ( $\left.\mathrm{IrO}_{3}\right)$ generation if the fuel is $\left\langle\mathrm{PuO}_{1} \cdot 99\right\rangle$ to that if the fuel is $\left\langle\mathrm{PuO}_{2} \cdot 00\right\rangle$ is $2 \times 10^{8}$. Thus, even the slight amount of fuel reduction at operating temperatures as low as $1600^{\circ} \mathrm{K}$ (Section $\mathrm{D}$, above) would great ly increase the probability of the FSA surviving reentry.

Similar calculations indicate that if the fuel reenters as $\left\langle E^{\prime} \mathrm{LO}_{1} \cdot 98\right\rangle$, the maximum $\left(\mathrm{IrO}_{2}\right)$ generation would be $5.8 \times 10^{-8} \mathrm{~g}$ or $5 \times 10^{-6} \mathrm{mil}$ in $5 \mathrm{~min}$. Generation of other specles such as $\left(\mathrm{PuO}_{2}\right)$ would be little affected if the fuel were $\left\langle\mathrm{PLO}_{1} \cdot 98\right\rangle$.

11. Loading Fuel as $\left\langle\mathrm{PuO}_{1} \cdot 98\right\rangle$. The above ealculations indicate that if the FSA attains orbit and operates at $1600-1800^{\circ} \mathrm{K}$, the fuel will reenter at a stolchiometry below $\left\langle\mathrm{PuO}_{2} \cdot 0\right\rangle$. At first glance, it would seem to be advantageous to employ $\left\langle\mathrm{PuO}_{1} \cdot{ }_{98}\right\rangle$ fuel in order to enhance reentry performance for those situations involving immedtate reentry due to failure to achieve orbit.

Immediately following fabrication, a plutonium dioxide fuel sphere may have an $O / P$ ratio less than 2.0 , perhaps 1.98 to 1.95 . However, a 100 watt sphere can have an ambient surface temperature as high as $800^{\circ} \mathrm{K}$. The free energy expressions listed in Table A-7 indicate that for the reaction

$$
\left\langle\mathrm{PuO}_{1 \cdot 98}\right\rangle+0.01\left(\mathrm{O}_{2}\right)=\left\langle\mathrm{PuO}_{2 \cdot 0}\right\rangle
$$

$\Lambda \mathrm{G}$ at $800^{\circ} \mathrm{K}$ is $-1.76 \mathrm{kcal} / \mathrm{mole}$. For the reaction

$$
\left\langle\mathrm{PuO}_{1} \cdot 95\right\rangle+0.025\left(\mathrm{O}_{2}\right)=\left\langle\mathrm{PuO}_{2 \cdot 0}\right\rangle
$$

$\triangle G$ at $800^{\circ} \mathrm{K}$ is $-4.24 \mathrm{kcal} / \mathrm{mole}$. In order to prevent oxidation of $\left\langle\mathrm{PuO}_{2-\mathrm{X}}\right\rangle$ to $\left\langle\mathrm{PuO}_{2} \cdot 0\right\rangle$, the fuel would have to be held in an environment with an oxygen pressure of less than $10^{-48} \mathrm{~atm}$. The normal Ar-flush inert boxes used at LASL and at MRC contain about $100 \mathrm{ppm}$ of oxygen corresponding to an $\left(\mathrm{O}_{2}\right)$ pressure of $10^{-4} \mathrm{~atm}$ or $10^{44}$ times the pressure nuedec to oxidize the fuel to $\left\langle\mathrm{PuO}_{2} \cdot 0\right\rangle$.

12. Summary. An FSA operating for a time at 1600$1800^{\circ} \mathrm{K}$ will survive reentry at $2000^{\circ} \mathrm{K}$, provided no impurities such as $<\mathrm{IrO}_{2}>$ were initially present in significant amounts. An FSA would also be expected to survive sn 
immediate reentry at $2000^{\circ} \mathrm{K}$. Loss rates of significant vapor species are summarized in Tables $\mathrm{C}-2$ and $\mathrm{C}-3$.

\section{G. Reentry at $2100^{\circ} \mathrm{K}$ if Fuel is $\left\langle\mathrm{PuO}_{2}, n\right\rangle$}

If the reentry temperature is increased to $2100^{\circ} \mathrm{K}$, the "worst case" situation is as follows.

1. Oxygen. The equilibrium partial pressure of $\left(\mathrm{O}_{2}\right)$ at $2100^{\circ} \mathrm{K}$ is 27 atm ( Table $\mathrm{A}-9$ ). This leads to a maximum $\left(\mathrm{O}_{2}\right)$ loss rate of

$$
\mathrm{Z}_{\mathrm{O}_{2}}=6.7 \times 10^{3} \mathrm{~g} / \mathrm{sec} \text {. }
$$

The maximum rate at which $\left(\mathrm{O}_{2}\right)$ could effuse out the vents is

$$
w_{\mathrm{O}_{2}}=8 \times 10^{-4} \mathrm{~g} / \mathrm{sec} \text {. }
$$

Thus, in $5 \mathrm{~min}$, the fuel would be reduced to $\left\langle\mathrm{PuO}_{1} \cdot{ }_{98}\right\rangle$. Once the ruel attained a stoichiometry of $\left\langle\mathrm{PuO}_{1} \cdot 98\right.$ the $\left(O_{2}\right)$ partial pressure becomes $4.0 \times 10^{-5} \mathrm{~atm}$ and the loss rate from the fuel decreases to $9.9 \times 10^{-3} \mathrm{~g} / \mathrm{sec}$. The rate at which $\left(\mathrm{O}_{2}\right)$ at a partial pressure of $4.0 \times 10^{-5} \mathrm{~atm}$ can effuse through the vents is $1.2 \times 10^{-9} \mathrm{~g} / \mathrm{sec}$. Thus, during reentry the fuel stoichiometry would go from $\left\langle\mathrm{PuO}_{2} \cdot \vec{\theta}\right\rangle$ to $\left\langle\mathrm{PuO}_{1} \cdot \mathrm{98}\right\rangle$. These values for a closed syatem (FSA) may be compared to those reported by Messier 17 for an open system (Knudsen cell) at $2090^{\circ} \mathrm{K}$. He reports that $\left\langle\mathrm{PuO}_{2}\right\rangle$ goes to $\left\langle\mathrm{PuO}_{1} \cdot \mathrm{g3}\right\rangle$ in $17 \mathrm{~min}$, to $\left\langle\mathrm{PuO}_{1} \cdot 91\right\rangle$ in 30 min and to $\left\langle\mathrm{PuO}_{1} \cdot \mathrm{gO}_{0}\right\rangle$ in $60 \mathrm{~min}$.

2. Effect of $(0)$. The equilibrium partial pressure of $(\mathrm{O})$, corresponding to an $\left(\mathrm{O}_{2}\right)$ pressure of $27 \mathrm{~atm}$, is $7.2 \times 10^{-3} \mathrm{~atm}$. The maximum generation rate of $(O)$ from the sphere surface is calculated to be

$$
\mathrm{z}_{\mathrm{O}}=1.3 \mathrm{~g} / \mathrm{sec} \text {. }
$$

Thus, the $(O)$ contribution to the total amount of oxygen released is on'y $0.02 \%$ that of $\left(\mathrm{O}_{2}\right)$.

3. Effect of Helium. The $\left(\mathrm{O}_{2}\right)$ generation rate given by Eq. (121) corresponds to $1.3 \times 10^{27}$ molecules $/ \mathrm{sec}$. This is $10^{13}$ times greater than the (He) generation rate and the generation of (He) will not affect the generation of $\left(\mathrm{O}_{2}\right)$.

4. Reactions with the Iridium Shell. The free energy of formation for $\left(\mathrm{IrO}_{3}\right)$, extrapolated to $2100^{\circ} \mathrm{K}$, is 26.55 $\mathrm{kcal} / \mathrm{mole}$. From this, the partial pressure of $\left(\mathrm{IrO}_{3}\right)$ is calculated to be $0.24 \mathrm{~atm}$. This corresponds to a generation rate at the surface of the iridium saell of

$$
\mathrm{Z}_{\mathrm{IrO}_{3}}=17.9 \mathrm{~g} / \mathrm{sec}
$$

or an iridium loss of about $1.1 \mathrm{in.}$ in $5 \mathrm{~min}$. The amount that could effuse out the vents in $5 \mathrm{~min}$ is $5.8 \times 10^{-3} \mathrm{~g}$. These are maximum values and undoubtedly are much too large for the reasons discussed above for reentry at $2000^{\circ} \mathrm{K}$. However, it should be noted that the generation rate of $\left(\mathrm{IrO}_{\xi}\right)$, calculated for reentry at $2100^{\circ} \mathrm{K}$, is 180 times greater than that calculated for reentry at $2000^{\circ} \mathrm{K}$.

The free energy of formation for $\left(\mathrm{IrO}_{2}\right)$, extrapolated to $2100^{\circ} \mathrm{K}$, is $40.3 \mathrm{kcal} / \mathrm{mole}$. This leads to a calculated (IrO) partial pressure of $1.7 \times 10^{-3}$ atm and a calculated ( $\mathrm{IrO}_{2}$ ) generation rate of

$$
\mathrm{Z}_{\text {IrO }_{2}}=1.2 \mathrm{~g} / \mathrm{sec} \text {. }
$$

This corresponds to about $113 \mathrm{mil}$ of iridium in $5 \mathrm{~min}$. Again, this value is too high, but the values calcuiated at $2100^{\circ} \mathrm{K}$ are about 50 times those calculated at $2000^{\circ} \mathrm{K}$.

5. $\left(\mathrm{PuO}_{2}\right)$. The equilibrium partial pressure of $\left(\mathrm{PuO}_{2}\right)$ above $\left\langle\mathrm{PuO}_{2}>\right.$ at $2100^{\circ} \mathrm{K}$ is $4.6 \times 10^{-7} \mathrm{~atm}$. This corresponds to a loss of $0.1 \mathrm{~g}$ of $\left(\mathrm{PuO}_{2}\right)$ from the sphere in $5 \mathrm{~min}$, and a loss of $1.2 \times 10^{-8} \mathrm{~g}$ through the vents. Vaporization of $\left(\mathrm{PuO}_{2}\right)$ will not appreciably affect reentry.

6. (PuO) and ( $\mathrm{Pu})$. The equilibrium pressure of (PuO) above $\left\langle\mathrm{PuO}_{2}\right\rangle$ is $6.1 \times 10^{-13} \mathrm{~atm}$. This corresponds to a loss from the sphere of $1.3 \times 10^{-7} \mathrm{~g}$ in $5 \mathrm{~min}$. During this time, $1.5 \times 10^{-14} \mathrm{~g}$ could escape through the vents.

The equilibrium partial pressure of $(\mathrm{Pu})$ is $1.0 \times 10^{-22}$ atm. In $5 \mathrm{~min}, 2 \times 10^{-17} \mathrm{~g}$ could leave the fuel sphere, and $2.4 \times 10^{-24} \mathrm{~g}$ could escape through the vents. The fuel will not be reduced sufficiently to ralse the $(\mathrm{Pu})$ pree sure high enough to form $<\mathrm{PuIr}_{2}>$.

Vaporization of ( $\mathrm{PuO}$ ) and (Pu) will not affect reentry.

7. Iridium and Carbon. The vapor pressure of iridfum metal at $2100^{\circ} \mathrm{K}$ is calculated from Eq. (32) to be $1.6 \times 10^{-9} \mathrm{~atm}$. In $5 \mathrm{~min}, 3.2 \times 10^{-4} \mathrm{~g}$ or $1 \times 10^{-4} \mathrm{mil}$ of iridium could be lost due to vaporization. The reported Ir-C eutectic temperature is $2570^{\circ} \mathrm{K}$, thus no $\mathrm{Ir}-\mathrm{C}$ interaction is expected at $2100^{\circ} \mathrm{K}$.

8. Impurity Effects. All comments noted above for impurity effects apply, except that these effects increage as the temperature is increased.

9. Reentry at $2100^{\circ} \mathrm{K}$ if the Fuel is $\left\langle\mathrm{PuO}_{1} \cdot 9 \mathrm{Q}\right\rangle$. If the FSA has operated for a perfod of time such that the fuel 
has been reduced to $\left\langle\mathrm{PuO}_{1} \cdot \mathrm{gB}_{\mathrm{B}}\right\rangle$ the oxygen partial pressure becomes $4.0 \times 10^{-5} \mathrm{~atm}$. The partial pressure of ( $\left.\mathrm{IrO}_{3}\right)$ then becomes $4.3 \times 10^{-10} \mathrm{~atm}$ and the generation rate becomes

$$
\mathrm{Z}_{\mathrm{IrO}_{3}}=3.2 \times 10^{-7} \mathrm{~g} / \mathrm{sec} .
$$

This value corresponds to $3 \times 10^{-5} \mathrm{mil}$ in $5 \mathrm{~min}$ and is $6 \times 10^{8}$ times lower than that given by $\mathrm{Eq}$. (124) If the fuel is $\left\langle\mathrm{PuO}_{\mathrm{L} \cdot 0}\right\rangle$. Thus, any reduction at all in the $\mathrm{O} / \mathrm{Pu}$ ratio in the fuel would greatly increase the probability of an FSA surviving reentry.

The partial pressure of ( $\left.\mathrm{IrO}_{2}\right)$ calculated assuming the fuel to be $\left.\left\langle\mathrm{PuO}_{1} \cdot 9\right\rangle\right\rangle$ is $2.6 \times 10^{-9} \mathrm{~atm}$. The generation rate then becomes $1.8 \times 10^{-6} \mathrm{~g} / \mathrm{sec}$, a value $7 \times 10^{5}$ times lower than that given by Eq. (125).

10. Summary. If the FSA has operated long enough for the fuel to be reduced even slightly the FSA should survive reentry. Vaporization results for significant species are summarized in Tables $\mathrm{C}-2$ and $\mathrm{C}-3$.

H. Reentry at $2200^{\circ} \mathrm{K}$ if the Fuel is $\left\langle\mathrm{PuO}_{2 \cdot 0}\right\rangle$

If the reentry temperature is increased to $2200^{\circ} \mathrm{K}$, and the FSA contains $\left\langle\mathrm{PuO}_{2} \cdot \mathrm{O}\right\rangle$ the pressures within the system become formidable.

1. Oxygen. The equilibrium partial pressure of $\left(\mathrm{O}_{2}\right)$ above $\left\langle\mathrm{PuO}_{2} \cdot \mathrm{o}\right\rangle$ at $2200^{\circ} \mathrm{K}$ is $620 \mathrm{~atm}(9100 \mathrm{psi})$. The $\left(\mathrm{O}_{2}\right)$ generation rate at the fuel surface is calculated to be

$$
\mathrm{Z}_{\mathrm{O}_{2}}=1.5 \times 10^{5} \mathrm{~g} / \mathrm{sec} \text {. }
$$

The rate at which $\left(O_{2}\right)$ can escape through the vents is

$$
w_{\mathrm{O}_{2}}=0.018 \mathrm{~g} / \mathrm{sec} \text {. }
$$

It would take 17 sec to remove enough oxygen from the FSA to reduce the fuel to $\left\langle\mathrm{PuO}_{1} \cdot{ }_{98}\right\rangle$. Once the fuel is $\left\langle\mathrm{PuO}_{1} \cdot{ }_{88}>\right.$ the partial pressur ? of $\left(\mathrm{O}_{2}\right)$ decreases to $5.6 \mathrm{x}$ $10^{-4} \mathrm{~atm}$ corresponding to a generation rate at the sphere surface of $0.14 \mathrm{~g} / \mathrm{sec}$. It would take $320 \mathrm{~d}$ for sufficient oxygen to leave the FSA in order for the fuel to be reduced from $\left\langle\mathrm{PuO}_{1} \cdot 9_{8}\right\rangle$ to $\left\langle\mathrm{PuO}_{1} \cdot 95\right\rangle$, therefore, the fuel will stabllize at a composition near $\left\langle\mathrm{PuO}_{1} \cdot \mathrm{gr}_{7}\right\rangle$.

2. Effect of $(\mathrm{O})$. The partial pressure of $(\mathrm{O})$ corresponding to an $\left(O_{2}\right)$ pressure of $620 \mathrm{~atm}$ is $6.7 \times 10^{-2} \mathrm{~atm}$. The generation rate of $(O)$ at the fuel surface is calculated to be $11.4 \mathrm{~g} / \mathrm{sec}$ so that the $(\mathrm{O})$ contributes onily about $.008 \%$ of the total oxygen loss.
3. Effect of Helium. The generation rate of $\left(O_{2}\right)$ is $10^{13}$ times greater than that of ( $\left.H e\right)$ and helium generation will not affect $\left(O_{2}\right)$ generation.

4. Reactions with the Iridium Shell. The free energy of formation of ( $\mathrm{IrO}_{3}$ ), extrapolated to $2200^{\circ} \mathrm{K}$, is 27.61 $\mathrm{kcal} / \mathrm{mole}$. The partial pressure of $\left(\mathrm{IrO}_{\mathrm{g}}\right)$ is calculated to be $1.45 \mathrm{~atm}$. This leads to a generation rate of $\left(\mathrm{IrO}_{3}\right)$ at the inner surface of the iridium shell of

$$
\mathrm{Z}_{\mathrm{IrO}_{3}}=1044 \mathrm{~g} / \mathrm{sec} \text {. }
$$

This value corresponds to a loss of about $300 \mathrm{mil}$ of iridfum per second. The maximum rate at which ( $\left(1 \mathrm{O}_{3}\right)$ could leave the FSA is $0.03 \mathrm{~g}$ in $5 \mathrm{~min}$. These values which are 1000 times greater than the values calculated at $2000^{\circ} \mathrm{K}$, are extreme values and are undoubtedly too high. However, even the Rice Kinetic data predicts a loss of 3600 mil of iridium in 5 min.

The free energy of formation for $\left(\mathrm{IrO}_{2}\right)$, extrapolated to $2200^{\circ} \mathrm{K}$, is $39.9 \mathrm{kcal} / \mathrm{mole}$. The partial pressure of $\left(\mathrm{IrO}_{2}\right)$ is calculated to be $0.067 \mathrm{~atm}$ and the generation rate at the surface of the iridium shell is calculated to be $47 \mathrm{~g} / \mathrm{sec}, 2000$ times greater than at $2000^{\circ} \mathrm{K}$.

5. $(\mathrm{PuO}),(\mathrm{PuO})$ and $(\mathrm{Pu})$. The partial pressures above $\left\langle\mathrm{PuO}_{2} .0\right\rangle$ at $2200^{\circ} \mathrm{K}$ are listed in Table A-9 as $P_{\mathrm{PuO}_{2}}=2.0 \times 10^{-6} \mathrm{~atm}, P_{\mathrm{PuO}}=1.4 \times 10^{-12} \mathrm{~atm}$ and $\mathbf{P}_{\mathbf{P u}}=1.7 \times 10^{-22} \mathrm{~atm}$. In $5 \mathrm{~min}$, the maximum losses from the sphere surface are calculated to be: $0.42 \mathrm{~g}$ $\left(\mathrm{DuO}_{2}\right), 2.9 \times 10^{-7} \mathrm{~g}(\mathrm{PuO})$, and $3.4 \times 10^{-17} \mathrm{~g}(\mathrm{Pu})$. The maximum amounts that could effuse through the vents in $5 \mathrm{~min}$ are: $5.0 \times 10^{-8} \mathrm{~g}\left(\mathrm{PuO}_{2}\right), 3.4 \times 10^{-14} \mathrm{~g}(\mathrm{PuO})$, and $4.0 \times 10^{-24} \mathrm{~g}(\mathrm{Pu})$. Thus, it 's concluded that vaporization of plutonium-containing gaseous species will not affect satisfactory reentry of the FSA. No $\left\langle\mathrm{PuIr}_{2}\right\rangle$ will form unless the fuel is reduced to a stoichlometry of $\left\langle\mathrm{PuO}_{1} \cdot 7_{5}\right\rangle$

6. Iridium and Carbon. The vapor pressure of Iridium at $2200^{\circ} \mathrm{K}$ is $8.5 \times 10^{-9} \mathrm{~atm}$. Thus, the iridium shell could lose $0.03 \mathrm{mil}$ during a $5 \mathrm{~min}$ reentry. No Ir-C compound will form and the reported Ir-C eutectic temperature is about $2570^{\circ} \mathrm{K}$. However, impurities such as silicon in either the Iridium or graphite can reduce this temperature greatly. The Ir-C eutectic is reported to be about $2400^{\circ} \mathrm{K}$ if $1 \mathrm{wt}$. $\%$ sflicon is present. ${ }^{26}$ 
7. Reentry at $2200^{\circ} \mathrm{K}$ if the Fuel is $\left\langle\mathrm{PuO}_{1} \cdot \mathrm{s8}_{8}\right\rangle$. If the FSA has operated in the range $1600-1800^{\circ} \mathrm{K}$ long enough for the fuel to become $\left\langle\mathrm{PuO}_{1} \cdot 9{ }^{2}\right\rangle$, the FSA would undoubtedly survive reentry at $2200^{\circ} \mathrm{K}$. The equilibrium partial pressure of $\left(\mathrm{O}_{2}\right)$ above $\left\langle\mathrm{PuO}_{1} \cdot 88\right\rangle$ at $2200^{\circ} \mathrm{K}$ is $5.6 \times 10^{-4} \mathrm{~atm}$. This value is $10^{6}$ times less than that above $\left\langle\mathrm{PuO}_{2} \cdot 0\right\rangle$. Thus, even a slight reduction of the $\mathrm{O} / \mathrm{Pu}$ ratio in the fuel would greatly reduce the $\left(\mathrm{O}_{2}\right)$ partial pressure and the subsequent production of $\left(\operatorname{Ir} \mathrm{D}_{3}\right)$ and ( $\mathrm{IrO}_{2}$ ). It is possible that a $2 \mathrm{~h}$ vacuum bakeout of the FSA at $1600^{\circ} \mathrm{K}$ in order to remove the helium inventory prior to launch will reduce the fuel sufficiently to allow the FSA to survive an immediate reentry of the capsule does not achieve orbit.

If the fuel reenters as $\left\langle\bar{F} u O_{1} \cdot 98\right\rangle$, the equilibrium $\left(\mathrm{O}_{2}\right)$ partial pressure will be $5.6 \times 10^{-4}$ atm and the maximum loss of $\left(\mathrm{O}_{2}\right)$ from the fuel surface is calculated to be $0.14 \mathrm{~g} / \mathrm{sec}$. The amount that could escape through the vents is $2.0 \times 10^{-9} \mathrm{~g} / \mathrm{sec}$. Thus, during a $5 \mathrm{~min}$ reentry the fuel would be reduced from $\left\langle\mathrm{PuO}_{1} \cdot \mathrm{gg}_{9}\right\rangle$ to about $\left\langle\mathrm{PuO}_{1 \cdot 98}\right\rangle$.

The partial pressure of $\left(\mathrm{IrO}_{3}\right)$ is calculated to be $2.4 \times 10^{-8} \mathrm{~atm}$. This leads to a calculated generation rate of $\left(\mathrm{IrO}_{3}\right)$ of $1.7 \times 10^{-5} \mathrm{~g} / \mathrm{sec}$ or a loss of $1.5 \times 10^{-3}$ mil of iridium in 5 min. This value is $6 \times 10^{8}$ times lower than that calculated if the fuel is $\left\langle\mathrm{PuO}_{2} \cdot 0\right\rangle$.

The calculated partial pressure of $\left(\mathrm{IrO}_{2}\right)$ is $6.1 \times 10^{-8}$ atm. The calculated( $\left(\mathrm{IrO}_{2}\right)$ generation rate $4.2 \times 10^{-5} \mathrm{~g} /$ sec is $1 \times 10^{6}$ times lower than that calculated if the fuel is $\left\langle\mathrm{PuO}_{2} \cdot 0\right\rangle$. This value corresponds to a loss of $4 \times 10^{-3}$ mil of iridium in 5 min.

8. Summary. It is unlikely that an FSA would survive reentry at $2200^{\circ} \mathrm{K}$ if the fuel were $-\mathrm{PuO}_{2} \cdot 0^{>}$. It was noted above that when a $<\mathrm{PuO}_{2}>$ pellet was heated in an iridium capsule for $30 \mathrm{~min}$. at $2200^{\circ} \mathrm{K}$, no deleterious effects were observed. 57 However, it is likely that some reduction of the fuel occurred during the heat up period so that at $2200^{\circ} \mathrm{K}$, the fuel was actually $\left\langle\mathrm{PuO}_{2}-\mathrm{X}\right\rangle$. The calculations discussed above indicate that if the FSA has operated long enough for the fuel to be reduced, the FSA should survive reentry at $2200^{\circ} \mathrm{K}$. The vaporization of significant species, assuming $<\mathrm{PuO}_{2} \cdot 0>$ fuel, is summarized in Tables $\mathrm{C}-2$ and $\mathrm{C}-3$.

\section{Miscellaneous Calculations}

1. Water. The data listed in Tables B-44 and B-45 indicate that, in the range $1600-1700^{\circ} \mathrm{K},\left(\mathrm{H}_{2} \mathrm{O}\right)$ will oxidize lower oxides to $\left\langle\mathrm{PuO}_{1} \cdot 95\right\rangle$ or $\left\langle\mathrm{PuO}_{1} \cdot 9_{2}\right\rangle$, but will not affect $\left\langle\mathrm{PuO}_{2} \cdot 0\right\rangle$. In addition the Rice Kinetic data indicate that $\left(\mathrm{H}_{2} \mathrm{O}\right)$ enhances the reaction of $\left(\mathrm{O}_{2}\right)$ with $<1 \mathrm{r}>$ to form $\left(\mathrm{IrO}_{3}\right)^{35,37}$ Actually an FSA should contain very little water because the fuel, when clad in iridium, has an ambient temperature of about $700^{\circ} \mathrm{C}$. In addition, the FSA will receive a $1500^{\circ} \mathrm{C}$ treatment to anneal the iridium plus a vacuum bakeout to remove helium prior to launch. Accordingly, $\left(\mathrm{H}_{2} \mathrm{O}\right)$ is not expected to be an important impurity in FSA systems.

2. Carbon and Carbon Monoxide. The dats 'isted in Tables B-8 to B-16 indicate that, above $1600^{\circ} \mathrm{K},<\mathrm{C}>$ will react with $\left\langle\mathrm{PuO}_{2}\right\rangle$ to produce $\left\langle\mathrm{PuO}_{2}-\mathrm{x}\right\rangle$ and $(\mathrm{CO})$. In addition, the data listed in Tables $\mathrm{B}-18$ to $\mathrm{B}-33$ indicate that, above $1700^{\circ} \mathrm{K},(\mathrm{CO})$ will reduce $\left\langle\mathrm{PuO}_{2}\right\rangle$.

Analyses of fuel spheres fabricated both at MRC and at I.ASL indicate very little contamination with carbon. The data discussed above in Section II, predict that the fuel wlll not come in contact with carbon during FSA operation or reentry. Thus, any $(\mathrm{CO})$ generated within an HSA would be due to Impurities outside the FSA's or to mechanical faflure.

One means by which the fuel could come in contact with carbon to produce $(\mathrm{CO}$ ) would be for a small meteorite particle to penetrate the HSA and enter an FSA. If this were to happen while an FSA were operating at $1700^{\circ}$ $K$, the data in Table B-11 predict that, under equilibrium conditions, the fuel would be reduced to $\left\langle\mathrm{PuO}_{1} \cdot 80\right\rangle$ and the $(\mathrm{CO})$ generated would have a partial pressure of about $50 \mathrm{~atm}$. For this $(\mathrm{CO})$ to affect the other FSA's it would have to enter through the vents. The maximum rate at which this could occur is $1.8 \times 10^{-3} \mathrm{~g} / \mathrm{sec}$. The data in Table B-28 indicate that, under equilibrium conditions at $1700^{\circ} \mathrm{K}$, (CO) will reduce $\left\langle\mathrm{PuO}_{2} \cdot 0\right\rangle$ to $\left.\left\langle\mathrm{PuO}_{1} \cdot 98\right\rangle\right\rangle$. Thus, if the $(\mathrm{CO})$ partial pressure were $50 \mathrm{~atm}$, sufficient $(\mathrm{CO})$ to reduce tha fuel to $\left\langle\mathrm{PuO}_{2} \cdot \mathrm{O}^{\rangle}\right\rangle$could enter an FSA in about $7 \mathrm{~min}$. The discussions above indicate that, at the 
operating temperature, the fuel would stabilize at about $\left\langle\mathrm{PuO}, \cdot{ }_{98}\right\rangle$ in any case. In the actual event of a meteorite penetrating an FSA in this manner, equilibrium conditions would not be attained, and the $(\mathrm{CO})$ generated would vent to space through the hole in the HSA, leaving the other F'SA's unaffected.

\section{J. Summary}

\section{Comments.}

a. The calculations are based on an FSA containing only $\left\langle\mathrm{PuO}_{2}\right\rangle$, $\langle\mathrm{Ir}\rangle$ and $\langle\mathrm{C}\rangle$. The effect of other species, such as $\left\langle\mathrm{HfO}_{2}\right\rangle$ on the vent covers, has not been considered.

b. The calculations are based on an FSA having two vents, each with a diam. of 0.002 in. Changes in vent sizes would affect the calculations somewhat. In addition, the calculations were based on open vents. Actual FSA's will be provided with some type of vent cover that will decrease the rates at which gaseous species can leave the FSA's. Reaction rates will be accordingly reduced.

c. The calculations are based on published thermodynamic data. The data available for solid and gaseous plutonium oxides, as well as for iridium and carbon are believed to be reliable. Unfortunately the data published for the gaseous iridium oxides are questionable The reaction rates between $\left(\mathrm{O}_{2}\right)$ and $<\mathrm{Ir}>$ to form $\left(\operatorname{IrO}_{3}\right)$ and $\left(I r O_{2}\right)$, predicted from the thermodynamic data, are much higher than the rates obtained in a limited number of kinetics experiments. For each calculation, the thermodynamic data employed were those leading to the worst case, i.e., maximum reaction between the FSA components. In actual life, the thermochemical stability of the FSA system is expected to be better than that predicted by the calculations.

\section{Conclusions}

a. It is important that impurities such as $<\mathrm{IrO}_{2}>$ be held to minimum values. The maximum amount of $<\mathrm{IrO}_{2}>$ that can be present in the iridium without affecting FSA operation is about $1 \mathrm{ppm}$. The suggested maximum allowable level for routine operations is $<20 \mathrm{ppm}$.
Other impurities such as silicon and iron can, if present in the iridium, lower the $\mathrm{Ir}-\mathrm{C}$ eutectic temperature and thus affect reentry.

$$
\text { b. If the impurities are kept to low levels, an }
$$

FSA should function satisfactorily at operating temperatures in the range $1600-1750^{\circ} \mathrm{C}$. Slightly higher operating temperatures could be employed with subsequent reduction in mission lifetimes.

c. An FSA that has operated for more than a month or so could probably be reentered at temperatures as high as $2200^{\circ} \mathrm{K}\left(1927^{\circ} \mathrm{C}\right)$. Obviously, the Jower the reentry temperature, the better. If an FSA containing $<\mathrm{PuO}_{2 \cdot 0}>$ fuel must reenter immediaiely due to failure to achieve orbit, the maximum reentry temperature should not exceed $1850^{\circ} \mathrm{C}$. 


\section{REFERENCES}

1. R. C. Feber and C. C. Herrick, "Ideal Gas Thermodynamic Functions of Lanthanide and Actinide Elements:" Los Alamos Scientific Labolatory report L.A-3184 (February 1965) .

2. M. H. Rand, "Thermochemical Properties", in Atomic Energy Review, Vol. 4, Special Issue No. 1, IAEA, Vienna, 1966.

3. T. E. Phipps, G. W. Sears, R. L. Seifert and O. C. Simpson, "Vapor Pressure of Liquid Plutonium;" Proc. UN Int. Conf. PUAE $\underline{7}$ (1956) . pp 382386.

4. R. N. R. Mulford, "The Vapor Pressure of Plutonium" in Thermodynamics, Vol. 1, IAEA, Vienna (1966). pp 231-241.

5. R. A. Kent, "Mass Spectrometric Studies of Plutonium Compounds at High Temperatures III. The Vapor Pressure of Plutonium," High Temp. Science 1. 169 (1969).

6. JANAF Thermochemical Tables, Second Edition, D. R. Stull and H. Prophet, Eds. Office of Standard Reference Data, National Bureau of Standards, NSRDS-NBS37, 1971.

7. R. N. R. Mulford and C. E. Holley, Jr., "Thermodynamic Properties of Plutonium Oxides;" presented to a Panel at the IAEA, Vienna, Oct. 24-28, 1966.

8. T. L. Markin and M. H. Rand, "Thermodynamic Data for Plutonium Oxides," in Thermodynamics, Vol. 1, IAEA, Vienna (1966). pp 145-156.

9. G. K. Johnson, E. H. Van Deventer, O. L. Kruger and W. N. Hubbard, "The Enthalpies of Formation of Plutonium Dioxide and Plutorium Mononitride," J. Chem. Thermodynamics $1,89(1 \mathrm{6} 69)$.

10. T. A. Sandenaw, "Heat Capacity of Plutonium Dloxide below $325^{\circ} \mathrm{K}$;" J. Nucl. Mater. 10, 165(1963).

11. T. K. Engel, "The Heat Capacities of $\mathrm{Al}_{2} \mathrm{O}_{3}, \mathrm{UO}_{2}$ and $\mathrm{PuO}_{2}$ from 300 to $1100^{\circ} \mathrm{K}$,' J. Nucl. Mater. 31, 211 (1969).

12. E. F. Westrum, Jr., J. B. Hatcher and D. W. Osborne, "The Entropy and Low Temperature Heat Capacity of Neptunium Dioxide," J. Chem. Phys. 21, 419 (1953).

13. O. L. Kruger and H. Savage, "Heat Capacity and Thermodynamic Properties of Plutonium Dioxide," J. Chem. Phys. 49,4540 (1968).
14. A. E. Ogard, "High Temperature Heat Content of Plutonium Dioxide"' in Plutonium 1970 and Other Actinides, W. N. Miner, Ed., Proc. 4th Intern. Conf. Plutonium and Other Actinides, Santa Fe, New Mexico, Oct. 5-9, 1970, Part I, pp 78-83.

15. R. J. Ackermann, R. L. Faircloth and M. H. Rand, "Thermodynamic Study of the Vaporization Behavior of the Substoichiometric Plutonium Dioxide Phase," J. Phys. Chem. 70, 3698(1966).

16. R. W. Ohse and C. Ciani, "Evaporation Behavior and High-Temperature Thermal Analysis of Substoichiometric Plutonium Oxide for $1.51<\mathrm{O} / \mathrm{Pu}<$ 2.00"' in Thermodynamics of Nuclear Materials 1967, IAEA, Vienna (1968). pp 545-557.

17. D. R. Messier, "Evaporation of Hypostoichiometric Plutonium Dioxide from $2070^{\circ}$ to $2380^{\circ} \mathrm{K}$ ' J. Am. Ceram. Soc. 51, 710 (1968).

18. J. E. Battles, J. W. Reishus and W. A. Shinn, "Volatilization Studies of Plutonium Compounds by Mass Spectrometry. Plutonium-Oxygen System;" Argonne National Laboratory report ANL-7575 (1968).

19. R. A. Kent, Los Alamos Scientific Laboratory, unpublished data, 1969-1970.

20. T. E. Phipps, G. W. Sears and O. C. Simpson, "The Volatility of Plutonium Dioxide," J. Chem. Phys. 18, 724 (1950).

21. F. D. Rossini, "Report on International Practical Temperature Scale of 1968," J. Chem. Thermodynamics $\underline{2}, 447$ (1970).

22. R. C. Paule and J. L. Margrave, "Vapor Pressures of Platinum Metals III. Iridium and Ruthenium," J. Phys. Chem. 67, 1896 (1963).

23. D. R. Stull and G. C. Sinke, Thermodynamic Properties of the Elements, (No.18 in Advances in Chemistry Series, The American Chemical Society, Washington, D. C., 1956).

24. M. R. Nadler and C. P. Kempter, "Some Solidus Temperatures in Several Metal-Carbor Systems", J. Chem. Phys. 33, 1580 (1960).

25. C. E. Lowell, R. A. Mercuri and H. F. Volk, "Research on High Temperature Protective Coatings for Graphite-Mechanical Compatibility of Iridium with Graphite;" Union Carbide Corporation report AD853977(1964), pp. 35-37.

26. D. P. Harmon, "Iridium-Base Alloys and Their Behavior in the Presence of Carbon", Air Force Materfals Laboratory report AFML-TR-66-290 (1966). 
27. J. G. Reavis, Los Alamos Scientific Laboratory, unpublished data: 1970 .

28. W. J. Arnault and R. B. McLellan, "The Solubility of Carbon in Rhodium, Ruthenium, Iridium and Rhenium," Scrypta Metallurgica $\underline{6}, 1013$ (1972).

29. E. H. P. Cordfunke and G. Meyer, "The System Iridium-Oxygen II. The Dissociation Pressure of IrO $\mathrm{O}_{2}$ " Rec. Trav. Chim. 81,670 (1962).

30. H. Schäfer and H. J. Heitland, "Gleichgewichtsmes songen im System Iridium-Sauerstoff Gasformiges Iridiumtrioxyd;' Z. anorg. Chem. 304, 249 (1960).

31. W. E. Bell, M. Tagami and R. E. Inyard, "DisBociation of Iridium Oxide"' J. Phys. Chem. 70, 2048 (1966).

32. J. H. Norman, H. G. Staley and W. E. Bell, "Mass-Speatrometric Study of Gaseous Oxides of Iridium," J. Chem. Phys. 42, 1123 (1965) .

33. E. H. P, Cordfunke and G. Meyer, "The System Iridium-Oxygen. I. Measurements on the Volatile Oxide of Iridium," Rec. trav. chim. 81, 495(1962).

34. C. B. Alcock and G. W. Hooper, "Thermodynamics of the Gaseous Oxides of the Platinum-Group Metals"' Proc. Roy. Soc. A254, 551 (1960).

35. A. K. Kuriakose, R. A. Kent and J. L. Margrave, "Research on High Temperature Protective Coatings for Graphite-Evacoration of Iridium in the Presence of Oxygen", Union Carbide Corporation report AD853977(1964), pp 17-18.

36. C. A. Krier and R. I. Jaffee, "Oxidation of the Platinum-Group Metals", J. Less-Common Metals 5, 411 (1963).

37. A. K. Kuriakose and J. L. Margrave, "Kinetics of Oxidation of Iridium at High Temperatures", Appenaix $A$ in Union Carbide Corporation report ML-TDR 64-173, Part III (1965).

38. J. Rexer, "Research on High Temperature Protective Coatings for Graphite-Oxidation of Iridium," Union Carbide Corporation report AL853977(1964), pp 6-16.

39. J. Rexer, "High Temperature Protective Coatinge for Graphite-Gxidation of Iridium at High Temperatures;" Union Carbide Corporation report ML-TDR64-173, Part III (1965), pp 17-35.

40. W. M. Olsen, Los Alamos Scientific Laboratory, unpublished data, 1972.
41. P. S. Harris, B. A. Phillips, M. H. Rand and M. Tetenbaum, "The Volatility of Plutonium Carbides, Part I," Atomic Energy Research Establishment report AERE-R-5353 (1967).

42. E. K. Storms, "The Plutonium-Plutonium Dicarbide System" in The Refractory Carbides, (Academic Press, New York and London, 1967), Chap. XII, pp 214-224.

43. G. M. Campbell, L. J. Mullins and $J_{\text {. A. Leary, }}$ "Thermodynamic Properties of Plutonium Compounds by EMF Techniques," in Thermodynamics of Nuclear Materials 1967, IAEA, Vienna (1968), pp 75-88.

44. C. E. Holley, Jr., and E. K. Storms, "Actinide Carbides - A Review of Thermodynamic Properties" in Thermodynamics of Nuclear Materials 1967 . IAEA, Vienna (1968), pp 397-426.

45. W. M. Olsen and R. N. R. Mulford, "Thermodynamics of the Plutonium Carbides," in Thermodynamics of Nuclear Materials 1967, LAEA, Vienna (1968), pp 467-479.

46. M. H. Rand, "A Thermochemical Assessment of the Flutonium-Carbon System;" presented at a panel meeting, IAEA, Vienna, Sept., 1968.

47. R. A. Kent, "Mass Spectrometric Studies of Plutonium Compounds at High Temperatures. V. The Plutonium-Carbon System;' presented at the International Conference on Mass Spectrometry, Kyoto, Japan, Sept. 1969.

48. J. E. Battles, W. A. Shinn, P. E. Blackburn and R. K. Edwards, "Volatilization Studies of Plutonium Compounds by Mass Spectrometry", Argonne National Laboratory report ANL-7675(1969), pp 8184. See also, High Temp. Science 2, 80(1970).

49. G. K. Johnson, E. H. Van Deventer, O. L. Kruger and W. N. Hubbard, "The Enthalpy of Formation of Plutonium Monocarbide," J. Chem. Thermodynamics $\underline{2}, 617(1970)$.

50. G. M. Campbell, R. A. Kent and J. A. Leary, "Thermodynamic Properties of the PlutoniumCarbon System;" in Plutonium 1970 and Other Actinides, W. N. Miner, Ed., Proc. 4th Intern. Conf. Plutonium and Other Actinides, Santa Fe, New Mexico, Oct. 5-9, 1970, Part II, pp 781-790.

51. R. N. R. Mulford, F. H. Ellinger and K. A. Johnson, "The Plutonium-Carbon-Oxygen System, J. Nucl. Mat. $\underline{10}, 90$ (1963).

52. P. E. Potter, "The Ternary System PlutoniumCarbon-Oxygen;" A tomic Energy Research Establishment report AERE-R5544 (1967). 
53. P. E. Potter, "The Uranium-Plutonium-CarbonOxygen Systems;" J. Nucl. Mat. 느, 1 (1972).

54. J. G. Reavis, Los Alamos Scientific Laboratory, unpublished data, 1972 .

55. A. W. Nutt and M. Tokar, "Thermal Expansion of $\mathrm{PuO}_{2}$ "; Los Alamos Scientific Laboratory Report LA-4945 (June, 1972) .

56. R. P. Iczkowski, J. L. Margrave and S. M. Robinson, "Effusion of Gases Through Conical Orifices" J. Phys. Chem. 67, 229 (1963).

57. D. Pavonne, Los Alamos Scientific Laboratory, unpublished data, 1972. 
APPENDIX A

THERMODYNAMIC DATA FOR COMPONENTS OF

FSA SYSTEMS

TABLE A-1

THERMODYNAMIC FUNCTIONS FOR GASEOUS PLUTONIUM

\begin{tabular}{|c|c|c|c|c|}
\hline Temp. ${ }^{{ }^{\circ} \mathrm{K}}$ & $\begin{array}{l}C_{p} \\
\text { eu }\end{array}$ & $\begin{array}{l}\mathrm{H}_{\mathrm{T}}^{\circ}-\mathrm{H}_{298}^{\circ} \\
\mathrm{cal} / \mathrm{mole} \\
\end{array}$ & $\begin{array}{l}\mathbf{s}_{\mathrm{T}}^{o}-\mathbf{s}_{228}^{o} \\
\underline{\text { eu }}\end{array}$ & $\frac{-\left(F_{T}^{0}-H_{298}^{0} / T\right)}{e u}$ \\
\hline 298 & 4.98 & 4 & 42.317 & 42.317 \\
\hline 300 & $4.98_{5}$ & 9 & 42.347 & 42.317 \\
\hline 400 & 5.10 & 512 & 43.794 & 42.513 \\
\hline 500 & 5.39 & 1036 & 44.961 & 42.889 \\
\hline 600 & 5.82 & 1596 & 45.980 & 43.321 \\
\hline 700 & 6.32 & 2203 & 46.915 & 43.768 \\
\hline 800 & 6.84 & 2861 & 47.794 & 44.217 \\
\hline 900 & 7.35 & 3571 & 48.629 & 44.661 \\
\hline 1000 & 7.84 & 4330 & 49.428 & 45.098 \\
\hline 1100 & 8.32 & 5138 & 50.198 & 45.527 \\
\hline 1200 & 8.79 & 5994 & 50.942 & 45.948 \\
\hline 1300 & 9.24 & 6895 & 51.664 & 46.360 \\
\hline 1400 & 9.68 & 7842 & 52.365 & 46.764 \\
\hline 1500 & i0.10 & 8831 & 53.047 & 47.160 \\
\hline 1600 & 10.48 & 9860 & 53.711 & 47.549 \\
\hline 1700 & 10.81 & 10924 & 54.356 & 47.930 \\
\hline 1800 & 11.10 & 12020 & 54.983 & 48.305 \\
\hline 1900 & 11.33 & 13142 & 55.589 & 48.672 \\
\hline 2000 & 11.51 & 14284 & 56.175 & 49.033 \\
\hline 2100 & 11.63 & 15442 & 56.740 & 49.386 \\
\hline 2200 & 11.70 & 16609 & 57.283 & 49.733 \\
\hline 2300 & 11.73 & 17781 & 57.804 & 50.073 \\
\hline 2400 & 11.73 & 18954 & 58.303 & 50.405 \\
\hline
\end{tabular}


TABLE A-2

THERMODYNAMIC FUNCTIONS FOR SOLID AND LIQUDD PLUTONIUM

\begin{tabular}{|c|c|c|c|}
\hline Temp. ${ }^{{ }^{\circ}}{ }_{K}$ & $\begin{array}{l}\mathrm{HI}_{\tau}^{\mathrm{O}}-\mathbf{H}_{298}^{\mathbf{O}} \\
\mathrm{cal} / \mathrm{mole} \\
\end{array}$ & $\begin{array}{c}\mathbf{S}_{\mathbf{T}}^{\mathbf{o}}-\mathbf{S}_{2988}^{\mathbf{o}} \\
\end{array}$ & $\frac{-\left(\mathrm{F}_{\mathrm{T}}^{\mathrm{O}}-\mathrm{H}_{228}^{\mathrm{o}} / \mathrm{T}\right)}{\mathrm{eu}}$ \\
\hline 298 & 0 & 0.00 & 13.200 \\
\hline 300 & 17 & 0.057 & 13.200 \\
\hline 400 & 867 & 2.502 & 13.534 \\
\hline 500 & 3257 & 7.569 & 14.255 \\
\hline 600 & 4107 & 9.119 & 15.474 \\
\hline 700 & 4957 & 10.429 & 16.547 \\
\hline 800 & 5807 & 11.564 & 17.505 \\
\hline 900 & 6657 & 12.565 & 18.368 \\
\hline $\mathbb{1 0 0 0}$ & 8177 & 14.201 & 19.224 \\
\hline 1100 & 9027 & 15.011 & 20.004 \\
\hline 1200 & 9877 & 15.750 & 20.720 \\
\hline 1300 & 10727 & 16.431 & 21.379 \\
\hline 1400 & 11577 & 17.061 & 21,991 \\
\hline 1500 & 12427 & 17.647 & 22.562 \\
\hline 1600 & 13277 & 18.196 & 23. 098 \\
\hline 1700 & 14127 & 18.711 & 23.601 \\
\hline 1800 & 14977 & 19.297 & 24.076 \\
\hline 1900 & 15827 & 19.656 & 24.526 \\
\hline 2000 & 16677 & 20.092 & 24.954 \\
\hline 2100 & 17527 & 20.507 & 25. 361 \\
\hline 2200 & 18377 & 20.903 & 25.749 \\
\hline 2300 & 19227 & 21.280 & 26.121 \\
\hline 2400 & 20077 & 21.642 & 26.477 \\
\hline
\end{tabular}


TABLE A-3

VAPORIZATION OF PLUTONIUM

\begin{tabular}{|c|c|c|c|c|}
\hline Temp., ${ }^{{ }^{K}} \mathbf{K}$ & $\begin{array}{l}\Delta H_{\mathrm{v}} \\
\mathrm{kcal} / \mathrm{mole}\end{array}$ & $\begin{array}{r}\Delta S_{\mathrm{v}} \\
\mathbf{e u}\end{array}$ & $\begin{array}{c}\Delta \mathrm{G}_{\mathrm{T}} \\
\mathrm{kcal} / \mathrm{mole}\end{array}$ & $\begin{array}{l}\text { Pressure, } \\
\text { Pu (atm) }\end{array}$ \\
\hline 298 & 83.00 & 29.12 & 74.32 & $3.14 \times 10^{-55}$ \\
\hline 500 & 80.78 & 24.20 & 68.68 & $9.59 \times 10^{-31}$ \\
\hline 800 & 80.05 & 23.04 & 61.63 & $1.46 \times 10^{-17}$ \\
\hline 900 & 79.914 & 22.865 & 59.336 & $3.91 \times 10^{-15}$ \\
\hline 1000 & 79.15 & 22.03 & 57.12 & $3.28 \times 10^{-13}$ \\
\hline 1100 & 79.11 & 21.99 & 54.92 & $1.23 \times 10^{-11}$ \\
\hline 1200 & 79.12 & 21.99 & 52.73 & $2.50 \times 10^{-10}$ \\
\hline 1300 & 79.11 & 21.99 & 54.92 & $1.23 \times 10^{-11}$ \\
\hline 1400 & 79.26 & 22.11 & 48.31 & $2.87 \times 10^{-8}$ \\
\hline 1500 & 79.40 & 22.20 & 46.10 & $1.98 \times 10^{-7}$ \\
\hline 1600 & 79.58 & 22.31 & 43.88 & $1.02 \times 10^{-6}$ \\
\hline 1700 & 79.80 & 22.45 & 41.63 & $4.44 \times 10^{-6}$ \\
\hline 1800 & 80.04 & 22.59 & 39.38 & $1.66 \times 10^{-5}$ \\
\hline 1900 & 80.32 & 22.73 & 37.12 & $5.37 \times 10^{-5}$ \\
\hline 2000 & 80.61 & 22.89 & 34.83 & $1.56 \times 10^{-4}$ \\
\hline 2100 & 80.92 & 23,03 & 32.55 & $4.10 \times 10^{-4}$ \\
\hline 2200 & 81.23 & 23.19 & 30.22 & $9.95 \times 10^{-4}$ \\
\hline 2300 & 81.55 & 23.33 & 27.90 & $2.24 \times 10^{-3}$ \\
\hline 2490 & 81.88 & 23.47 & 25.55 & $4.71 \times 10^{-9}$ \\
\hline
\end{tabular}


TABLE A-4

THERMODYNAMIC FUNCTIONS FOR GASEOUS O

\begin{tabular}{|c|c|c|c|c|}
\hline Temp. ${ }^{\circ} \mathrm{K}$ & $\begin{array}{l}\mathrm{H}_{\mathrm{T}}^{\mathrm{O}}-\mathrm{H}_{298}^{\mathrm{O}} \\
\mathrm{cal} / \mathrm{mole} \\
\end{array}$ & $\begin{array}{l}S_{\mathrm{T}}^{0}-\mathbf{S}_{288}^{0} \\
\text { eu }\end{array}$ & $\frac{-\left(\mathrm{F}_{\mathrm{T}}^{\mathrm{o}}-\mathrm{H}_{298}^{\mathrm{o}} / \mathrm{T}\right)}{\text { eq }}$ & $\begin{array}{c}\Delta \mathbf{S G}_{\mathbf{f}} \\
\underline{\mathrm{kcal} / \text { mole }}\end{array}$ \\
\hline 298 & 0 & 0.00 & 38.468 & 55.395 \\
\hline 500 & 1038 & 2.66 & 39.055 & 52.485 \\
\hline 800 & 2550 & 5.03 & 40.313 & 47.960 \\
\hline 900 & 3052 & 5.62 & 40.701 & 46.422 \\
\hline 1000 & 3552 & 6.15 & 41.067 & 44.875 \\
\hline 1100 & 4051 & 6.63 & $4 ! .412$ & 43.318 \\
\hline 1200 & 4551 & 7.06 & 41.737 & 41.755 \\
\hline 1300 & 5049 & 7.46 & 42.044 & 40.186 \\
\hline 1400 & 5548 & 7.83 & 42.335 & 38.611 \\
\hline 1500 & 6046 & 8.17 & 42.611 & 37.032 \\
\hline 1600 & 6544 & 8.50 & 42.873 & 35.448 \\
\hline 1700 & 7042 & 8.80 & 43.123 & 33.862 \\
\hline 1800 & 7540 & 9.08 & 43.361 & 32.271 \\
\hline 1900 & 8038 & 9.35 & 43.588 & 30.678 \\
\hline 2000 & 8536 & 9.61 & 43.806 & 29.082 \\
\hline 2100 & 9034 & 9.85 & 44.015 & 27.484 \\
\hline 2200 & 9532 & 10.08 & 44.216 & 25.884 \\
\hline 2300 & 10029 & 10.30 & 44.409 & 24.282 \\
\hline 2400 & 10527 & 10.51 & 14.596 & 22.679 \\
\hline
\end{tabular}


TABLE A-5

THERMODYNAMIC FUNCTIONS FOR GASEOUS $\mathrm{O}_{2}$

\begin{tabular}{|c|c|c|c|}
\hline Temp., ${ }^{\circ} \mathrm{K}$ & $\begin{array}{l}\mathrm{H}_{\mathrm{r}}^{\mathrm{O}}-\mathrm{H}_{298}^{\mathrm{O}} \\
\text { cal/mole } \\
\end{array}$ & $\begin{array}{c}s_{T}^{0}-s_{228}^{0} \\
\text { ou }\end{array}$ & $\frac{-\left(F_{T}^{0}-H_{2 Q S}^{0} / T\right)}{e u}$ \\
\hline 298 & 0 & 0.00 & 49.00 \\
\hline 500 & 1455 & 3.72 & 49.81 \\
\hline 800 & 3786 & 7.36 & 51.63 \\
\hline 900 & 4600 & 8.32 & 52.21 \\
\hline 1000 & 5427 & 9.19 & 52.76 \\
\hline 1100 & 6266 & 9.99 & 53.30 \\
\hline 1200 & 7114 & 10.72 & 53.80 \\
\hline 1300 & 7971 & 11.41 & 54.28 \\
\hline 1400 & 8835 & 12.05 & 54.74 \\
\hline 1500 & 9706 & 12.65 & 55.18 \\
\hline 1600 & 10583 & 13.22 & 55.61 \\
\hline 1700 & 11465 & 13.75 & 56.01 \\
\hline 1800 & 12354 & 14.26 & 56.40 \\
\hline 1900 & 13249 & 14.74 & 56.78 \\
\hline 2000 & 14149 & 15.21 & 57.14 \\
\hline 2100 & 15054 & 15.65 & 56.48 \\
\hline 2200 & 15966 & 16.07 & 57.82 \\
\hline 2300 & 16882 & 16.48 & 58.14 \\
\hline 2400 & 17804 & 16.87 & 58.46 \\
\hline
\end{tabular}


SELECTED THERMODYNAMIC FUNCTIONS FOR SOLD $\mathrm{PuO}_{2}$

\begin{tabular}{|c|c|c|c|c|c|}
\hline Temp., ${ }^{O_{K}}$ & $\begin{array}{l}\text { Cp } \\
\text { eu }\end{array}$ & $\begin{array}{l}\mathrm{H}_{\mathrm{r}}^{\mathrm{o}}-\mathbf{H}_{298}^{\mathrm{o}} \\
\mathrm{cal} / \mathrm{mole} \\
\end{array}$ & $\begin{array}{c}\mathbf{S}_{\mathrm{T}}^{\mathbf{0}}-\mathbf{S}_{2983}^{\mathbf{0}} \\
\mathrm{eu}\end{array}$ & $\frac{-\left(F_{\mathrm{T}}^{0}-\mathbf{H}_{298}^{0} \mathrm{~K}\right)}{\mathrm{eu}}$ & $\begin{array}{l}-\Delta G_{f} \\
\text { kcal/mole }\end{array}$ \\
\hline 298 & 16.39 & 0 & 0 & 19.700 & 239.54 \\
\hline 300 & 16.44 & 35 & 0.043 & 19.733 & 239.25 \\
\hline 400 & 18.02 & 1767 & 5.080 & 20.362 & 235.22 \\
\hline 500 & 18.97 & 3620 & 9.210 & 21.670 & 231.00 \\
\hline 600 & 19.66 & 5552 & 12.732 & 23.178 & 226.58 \\
\hline 700 & 20.23 & 7547 & 15.807 & 24.725 & 222.21 \\
\hline 800 & 20.74 & 9596 & 18.552 & 26.257 & 217.90 \\
\hline 900 & 21.21 & 11693 & 21.011 & 27.719 & 213.63 \\
\hline 1000 & 21.65 & 13836 & 23.267 & 29.132 & 209.35 \\
\hline 1100 & 22.09 & 16023 & 25.356 & 30.490 & 205.11 \\
\hline 1200 & 22.53 & 18253 & 27.300 & 31.789 & 200.93 \\
\hline 1300 & 22.95 & 20524 & 29.118 & 33.031 & 196.78 \\
\hline 1400 & 23.34 & 22838 & 30.830 & 34.217 & 192.68 \\
\hline 1500 & 23.75 & 25192 & 32.400 & 35.306 & 188.54 \\
\hline 1600 & 24.17 & 27586 & 34.001 & 36.460 & 184.61 \\
\hline 1700 & 24.56 & 30020 & 35.470 & 37.511 & 180.65 \\
\hline 1800 & 24.95 & 32495 & 36.889 & 38.536 & 176.71 \\
\hline 1900 & 25.36 & 35009 & 38.252 & 39.527 & 172.83 \\
\hline 2000 & 2575 & 37563 & 39.529 & 40.447 & 168.92 \\
\hline 2100 & 26.14 & 40157 & 40.822 & 41.399 & 165.17 \\
\hline 2200 & 26.53 & 42790 & 42.049 & 42.301 & 161.43 \\
\hline 2300 & 26.94 & 45462 & 43.239 & 43.176 & 157.70 \\
\hline 2400 & 27.34 & 48174 & 44.395 & 44.023 & 154.02 \\
\hline
\end{tabular}


TABLE A-7

FREE ENERGIES OF FORMATION AND PARTIAL MOLAR FREE ENERGIES OF ATOMIC OXYGEN FOR SOLID PLUTONIUM OXIDES

\begin{tabular}{|c|c|c|c|c|}
\hline \multirow{2}{*}{$\begin{array}{l}\text { Epecies } \\
\left\langle\mathrm{PuO}_{2 \cdot 00}\right\rangle\end{array}$} & \multicolumn{2}{|c|}{ 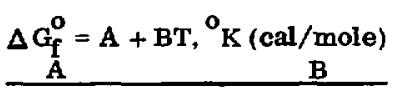 } & \multicolumn{2}{|c|}{$\underset{\mathrm{A}}{\Delta \mathrm{G}_{\mathrm{o}}=\mathrm{A}+\mathrm{BT},{ }^{\mathbf{o}_{\mathrm{K}} \mathrm{K}(\mathrm{cal} / \mathrm{mole})} \mathrm{B}}$} \\
\hline & $-249,500^{a}$ & 40.3 & $(-204,750)^{b}$ & $(87.7)$ \\
\hline$<\mathrm{PuO}_{1 \cdot 98}>$ & $-246,700$ & 39.0 & $-181,750$ & 63.4 \\
\hline$\left\langle\mathrm{PuO}_{1 \cdot 95}\right\rangle$ & $-243,100$ & 37.6 & $-178,000$ & 59.0 \\
\hline$\left\langle\mathrm{PuO}_{1} \cdot \mathrm{gl}_{2}\right\rangle$ & $-239,700$ & 36.4 & $-173,750$ & 54.1 \\
\hline$\left\langle\mathrm{PuO}_{1} \cdot{ }_{90}\right\rangle$ & $-237,500$ & 35.7 & $-171,150$ & 50.8 \\
\hline$\left\langle\mathrm{PuO}_{1} \cdot 85\right\rangle$ & $-232,100$ & 34.1 & $-164,250$ & 43.4 \\
\hline$\left\langle\mathrm{PuO}_{1 \cdot 80}\right\rangle$ & $-227,100$ & 32.9 & $-157,500$ & 36.1 \\
\hline$\left\langle\mathrm{PuO}_{1 \cdot 75}\right\rangle$ & $-222,500$ & 32.1 & $-151,500$ & 29.5 \\
\hline$\left\langle\mathrm{PuO}_{1 \cdot 70}\right\rangle$ & $-218,000$ & 31.5 & $-149,250$ & 26.5 \\
\hline$\left\langle\mathrm{PuO}_{1 \cdot 65}\right\rangle$ & $-213,600$ & 31.0 & $-150,250$ & 26.1 \\
\hline$\left\langle\mathrm{PuO}_{1 \cdot 61}\right\rangle$ & $-210,000$ & 30.6 & $-153,000$ & 26.9 \\
\hline$\left\langle\mathrm{PuO}_{1 \cdot 50}\right\rangle$ & $-200,300$ & 29.6 & $-153,000$ & 26.9 \\
\hline
\end{tabular}


TABLE A-8

VALUES FOR THE FREE ENERGY OF FORMATION FOR $<\mathrm{PuO}_{2}>$

\begin{tabular}{|c|c|c|c|}
\hline \multirow[b]{2}{*}{ Temp., ${ }^{\mathbf{O}_{\mathrm{K}}}$} & \multicolumn{2}{|c|}{$-\Delta G_{f}(\mathrm{keal} / \mathrm{mole})$} & \multirow[b]{2}{*}{$\Delta$, Percent } \\
\hline & Table A-6 & $\begin{array}{c}\text { Equation From } \\
\text { Table A-7 } \\
\end{array}$ & \\
\hline 298 & 239.54 & 237.49 & 0.86 \\
\hline 500 & 231.00 & 229.35 & 0.72 \\
\hline 800 & 217.90 & 217.26 & 0.29 \\
\hline 900 & 213.63 & 213.23 & 0.19 \\
\hline 1000 & 209.35 & 209.20 & 0.07 \\
\hline 1100 & 205.11 & 205.17 & 0.03 \\
\hline 1200 & 200.93 & 201.14 & 0.10 \\
\hline 1300 & 196.78 & 197.11 & 0.17 \\
\hline 1400 & 192.68 & 193.08 & 0.21 \\
\hline 1500 & 188.54 & 189.05 & 0.27 \\
\hline 1600 & 184.61 & 185.02 & 0.22 \\
\hline 1700 & 180.65 & 180.99 & 0.19 \\
\hline 1800 & 176.71 & 176.96 & 0.14 \\
\hline 1900 & 172.83 & 172.93 & 0.06 \\
\hline 2000 & 168.92 & 168.90 & 0.01 \\
\hline 2100 & 165.17 & 164.87 & 0.18 \\
\hline 2200 & 161.43 & 160.84 & 0.37 \\
\hline 2300 & 157.70 & 156.81 & 0.57 \\
\hline 2400 & 154.02 & 152.78 & 0.81 \\
\hline
\end{tabular}


CALCULATED EQUILIBRIUM PARTIAL PRESSURES ABOVE < $\mathrm{PuO}_{2}>$ (Pressures in Atmospheres)

\begin{tabular}{|c|c|c|c|c|}
\hline Temp.. ${ }^{\circ} \mathrm{K}$ & $\left(\mathrm{O}_{2}\right)$ & (Pu) & (PuO) & $\left(\mathrm{PuO}_{2}\right)$ \\
\hline 1500 & $2.9 \times 10^{-11}$ & $1.9 \times 10^{-24}$ & $3.9 \times 10^{-16}$ & $9.6 \times 10^{-13}$ \\
\hline 1600 & $1.2 \times 10^{-8}$ & $4.5 \times 10^{-24}$ & $2.0 \times 10^{-15}$ & $1.7 \times 10^{-11}$ \\
\hline 1700 & $2.5 \times 10^{-6}$ & $9.7 \times 10^{-24}$ & $8.1 \times 10^{-15}$ & $2.1 \times 10^{-10}$ \\
\hline 1800 & $2.8 \times 10^{-\xi}$ & $1.9 \times 10^{-23}$ & $2.9 \times 10^{-14}$ & $2.0 \times 10^{-9}$ \\
\hline 1900 & $1.9 \times 10^{-2}$ & $3.6 \times 10^{-23}$ & $8.8 \times 10^{-14}$ & $1.5 \times 10^{-8}$ \\
\hline 2000 & 0.87 & $6.3 \times 10^{-23}$ & $2.4 \times 10^{-13}$ & $9.0 \times 10^{-8}$ \\
\hline 2100 & $2.7 \times 10^{+1}$ & $1.0 \times 10^{-22}$ & $6.1 \times 10^{-13}$ & $4.6 \times 10^{-7}$ \\
\hline 2200 & $6.2 \times 10^{+2}$ & $1.7 \times 10^{-22}$ & $1.4 \times 10^{-12}$ & $2.0 \times 10^{-6}$ \\
\hline 2300 & $1.1 \times 10^{+4}$ & $2.6 \times 10^{-22}$ & $3.0 \times 10^{-12}$ & $7.9 \times 10^{-6}$ \\
\hline 2400 & $1.5 \times 10^{45}$ & $3.9 \times 10^{-22}$ & $6.1 \times 10^{-12}$ & $2.7 \times 10^{-5}$ \\
\hline
\end{tabular}

TABLE A-10

CALCULATED EQUILIBRIUM PARTIAL PRESSURES ABOVE <PuO $0_{1} \cdot 9.9$ (Pressures in Atmospheres)

\begin{tabular}{cccccc} 
Temp.. ${ }^{0} \mathrm{~K}$ & $\frac{\left(\mathrm{O}_{2}\right)}{3.5 \times 10^{-15}}$ & $\frac{(\mathrm{Pu})}{1.5 \times 10^{-20}}$ & $\frac{(\mathrm{PuO})}{3.4 \times 10^{-14}}$ & $\frac{\left(\mathrm{PuO}_{2}\right)}{9.2 \times 10^{-13}}$ \\
\cline { 1 - 3 } 1500 & $5.6 \times 10^{-13}$ & $9.2 \times 10^{-20}$ & $2.7 \times 10^{-13}$ & $1.6 \times 10^{-11}$ \\
1600 & $4.9 \times 10^{-11}$ & $4.5 \times 10^{-19}$ & $1.7 \times 10^{-12}$ & $2.0 \times 10^{-10}$ \\
1700 & $2.6 \times 10^{-9}$ & $1.9 \times 10^{-18}$ & $8.8 \times 10^{-12}$ & $1.8 \times 10^{-9}$ \\
1800 & $9.1 \times 10^{-8}$ & $7.1 \times 10^{-18}$ & $3.8 \times 10^{-11}$ & $1.4 \times 10^{-8}$ \\
1900 & $2.2 \times 10^{-6}$ & $2.3 \times 10^{-17}$ & $1.4 \times 10^{-10}$ & $8.3 \times 10^{-8}$ \\
2000 & $4.0 \times 10^{-5}$ & $6.5 \times 10^{-17}$ & $4.6 \times 10^{-10}$ & $4.2 \times 10^{-7}$ \\
2100 & $5.6 \times 10^{-4}$ & $1.7 \times 10^{-16}$ & $1.4 \times 10^{-9}$ & $1.9 \times 10^{-6}$ \\
2200 & $6.1 \times 10^{-3}$ & $4.2 \times 10^{-16}$ & $3.7 \times 10^{-9}$ & $7.2 \times 10^{-6}$ \\
2300 & $5.5 \times 10^{-2}$ & $1.8 \times 10^{-16}$ & $4.1 \times 10^{-9}$ & $2.5 \times 10^{-5}$ \\
2400 & & & & &
\end{tabular}


TABLE A-11

CALCULATED EQUILIBRIUM PARTIAL PRESSURES ABOVE < PuO $_{1}$ • $95^{\circ}$ (Pressures in Atmospheres)

\begin{tabular}{|c|c|c|c|c|}
\hline Temp., ${ }^{\circ} \mathrm{K}$ & $\left(\mathrm{O}_{2}\right)$ & $(\mathbf{P u})$ & (PuO) & $\left(\mathrm{PuO}_{2}\right)$ \\
\hline 1500 & $5.1 \times 10^{-16}$ & $9.8 \times 10^{-20}$ & $8.5 \times 10^{-14}$ & $8.8 \times 10^{-13}$ \\
\hline 1600 & $7.0 \times 10^{-14}$ & $7.0 \times 10^{-19}$ & $7.4 \times 10^{-13}$ & $1.5 \times 10^{-11}$ \\
\hline 1700 & $5.4 \times 10^{-12}$ & $4.0 \times 10^{-18}$ & $4.9 \times 10^{-12}$ & $1.9 \times 10^{-10}$ \\
\hline 1800 & $2.5 \times 10^{-10}$ & $1.9 \times 10^{-17}$ & $2.7 \times 10^{-11}$ & $1.8 \times 10^{-9}$ \\
\hline 1900 & $7.9 \times 10^{-9}$ & $7.7 \times 10^{-17}$ & $1.2 \times 10^{-10}$ & $1.3 \times 10^{-8}$ \\
\hline 2000 & $1.8 \times 10^{-7}$ & $2.7 \times 10^{-16}$ & $4.7 \times 10^{-10}$ & $7.8 \times 10^{-8}$ \\
\hline 2100 & $2.9 \times 10^{-6}$ & $8.5 \times 10^{-16}$ & $1.6 \times 10^{-9}$ & $4.0 \times 10^{-7}$ \\
\hline 2200 & $3.7 \times 10^{-5}$ & $2.4 \times 10^{-15}$ & $5.0 \times 10^{-9}$ & $1.8 \times 10^{-6}$ \\
\hline 2300 & $3.8 \times 10^{-4}$ & $6.4 \times 10^{-15}$ & $1.4 \times 10^{-8}$ & $6.7 \times 10^{-6}$ \\
\hline 2400 & $3.2 \times 10^{-3}$ & $1.6 \times 10^{-14}$ & $3.6 \times 10^{-8}$ & $2.3 \times 10^{-5}$ \\
\hline
\end{tabular}

TABLE A $A 12$

CALCULATED EQUILIBRIUM PARTIAL PRESSURES ABOVE < PuO $_{1} \cdot 92>$ (Pressures in Atmospheres)

\begin{tabular}{|c|c|c|c|c|}
\hline Temp., ${ }^{{ }^{0}}{ }_{K}$ & $\left(\mathrm{O}_{2}\right)$ & (Pu) & (PuO) & $\left(\mathrm{PuO}_{2}\right)$ \\
\hline 1500 & $6.4 \times 10^{-12}$ & $7.2 \times 10^{-19}$ & $2.2 \times 10^{-13}$ & $8.2 \times 10^{-13}$ \\
\hline 1600 & $7.3 \times 10^{-15}$ & $6.2 \times 10^{-18}$ & $2.1 \times 10^{-12}$ & $1.4 \times 10^{-11}$ \\
\hline 1700 & $4.8 \times 10^{-13}$ & $4.1 \times 10^{-17}$ & $1.5 \times 10^{-11}$ & $1.7 \times 10^{-10}$ \\
\hline 1800 & $2.0 \times 10^{-11}$ & $2.2 \times 10^{-16}$ & $8.8 \times 10^{-11}$ & $1.6 \times 10^{-9}$ \\
\hline 1900 & $5.4 \times 10^{-10}$ & $1.0 \times 10^{-15}$ & $4.2 \times 10^{-10}$ & $1.2 \times 10^{-8}$ \\
\hline 2000 & $1.1 \times 10^{-8}$ & $4.1 \times 10^{-15}$ & $1.7 \times 10^{-9}$ & $7.1 \times 10^{-8}$ \\
\hline 2100 & $1.6 \times 10^{-7}$ & $1.4 \times 10^{-14}$ & $6.3 \times 10^{-9}$ & $3.6 \times 10^{-7}$ \\
\hline 2200 & $1.9 \times 10^{-6}$ & $4.4 \times 10^{-14}$ & $2.0 \times 10^{-8}$ & $1.6 \times 10^{-6}$ \\
\hline 2300 & $1.7 \times 10^{-5}$ & $1.2 \times 10^{-13}$ & $5.9 \times 10^{-8}$ & $6.1 \times 10^{-6}$ \\
\hline 2400 & $1.4 \times 10^{-4}$ & $3.3 \times 10^{-13}$ & $1.6 \times 10^{-7}$ & $2.1 \times 10^{-5}$ \\
\hline
\end{tabular}


CALCULATED EQUILIBRIUM PARTIAL PRESSURES ABOVE < $\mathrm{PUO}_{1} \cdot$ 90 $>$ (Pressures in Atmospheres)

\begin{tabular}{|c|c|c|c|c|}
\hline Temp., ${ }^{o_{K}}$ & $\left(\mathrm{O}_{2}\right)$ & (Pu) & (PuO) & $\left(\mathrm{PuO}_{2}\right)$ \\
\hline 1500 & $1.3 \times 10^{-17}$ & $3.3 \times 10^{-18}$ & $4.6 \times 10^{-13}$ & $7.6 \times 10^{-13}$ \\
\hline 1600 & $1.4 \times 10^{-15}$ & $3.1 \times 10^{-17}$ & $4.5 \times 10^{-12}$ & $1.3 \times 10^{-11}$ \\
\hline 1700 & $8.1 \times 10^{-14}$ & $2.3 \times 10^{-16}$ & $3.4 \times 10^{-11}$ & $1.6 \times 10^{-10}$ \\
\hline 1800 & $3.0 \times 10^{-12}$ & $1.4 \times 10^{-15}$ & $2.1 \times 10^{-10}$ & $1.5 \times 10^{-9}$ \\
\hline 1900 & $7.7 \times 10^{-11}$ & $6.6 \times 10^{-15}$ & $1.0 \times 10^{-9}$ & $1.1 \times 10^{-8}$ \\
\hline 2000 & $1.4 \times 10^{-9}$ & $2.3 \times 10^{-14}$ & $4.4 \times 10^{-9}$ & $6.6 \times 10^{-8}$ \\
\hline 2100 & $2.0 \times 10^{-8}$ & $1.0 \times 10^{-13}$ & $1.6 \times 10^{-8}$ & $3.3 \times 10^{-7}$ \\
\hline 2200 & $2.2 \times 10^{-7}$ & $3.4 \times 10^{-13}$ & $5.4 \times 10^{-8}$ & $1.4 \times 10^{-6}$ \\
\hline 2300 & $2.0 \times 10^{-6}$ & $1.0 \times 10^{-12}$ & $1.6 \times 10^{-7}$ & $5.6 \times 10^{-6}$ \\
\hline 2400 & $1.5 \times 10^{-5}$ & $2.8 \times 10^{-12}$ & $4.3 \times 10^{-7}$ & $1.9 \times 10^{-5}$ \\
\hline
\end{tabular}

TABLE A-14

CALCULATED EQUILIBRIUM PARTIAL PRESSURES ABOVE <PuO ${ }_{1 \cdot 85}>$ (Pressures in Atmospheres)

\begin{tabular}{|c|c|c|c|c|}
\hline Temp., ${ }^{{ }} \mathrm{K}$ & $\left(\mathrm{O}_{2}\right)$ & (Pu) & (PuO) & $\left(\mathrm{PuO}_{2}\right)$ \\
\hline 1500 & $7.9 \times 10^{-19}$ & $4.6 \times 10^{-17}$ & $1.6 \times 10^{-12}$ & $6.4 \times 10^{-13}$ \\
\hline 1600 & $6.1 \times 10^{-17}$ & $5.7 \times 10^{-16}$ & $1.8 \times 10^{-11}$ & $1.1 \times 10^{-11}$ \\
\hline $1 \% 00$ & $2.8 \times 10^{-15}$ & $5.3 \times 10^{-15}$ & $1.5 \times 10^{-10}$ & $1.3 \times 10^{-10}$ \\
\hline 1800 & $8.4 \times 10^{-14}$ & $3.9 \times 10^{-14}$ & $9.9 \times 10^{-10}$ & $1.2 \times 10^{-9}$ \\
\hline 1900 & $1.7 \times 10^{-12}$ & $2.3 \times 10^{-13}$ & $5.4 \times 10^{-9}$ & $8.6 \times 10^{-9}$ \\
\hline 2000 & $1.2 \times 10^{-11}$ & $1.2 \times 10^{-12}$ & $2.5 \times 10^{-8}$ & $5.1 \times 10^{-8}$ \\
\hline 2100 & $3.2 \times 10^{-10}$ & $4.9 \times 10^{-12}$ & $9.9 \times 10^{-8}$ & $2.5 \times 10^{-7}$ \\
\hline 2200 & $3.0 \times 10^{-9}$ & $1.9 \times 10^{-11}$ & $3.5 \times 10^{-7}$ & $1.1 \times 10^{-6}$ \\
\hline 2300 & $2.3 \times 10^{-8}$ & $6.4 \times 10^{-11}$ & $1.1 \times 10^{-6}$ & $4.2 \times 10^{-6}$ \\
\hline 2400 & $1.5 \times 10^{-7}$ & $2.0 \times 10^{-10}$ & $3.2 \times 10^{-6}$ & $1.4 \times 10^{-5}$ \\
\hline
\end{tabular}


CALCULATED EQÜILIBRIUM PARTLAL PRESSURES ABOVE $<\mathrm{PuO}_{1} \cdot{ }_{80}>$ (Pressures in Atmospheres)

\begin{tabular}{|c|c|c|c|c|}
\hline Temp. ${ }^{\circ} \mathrm{K}$ & $\left(\mathrm{O}_{2}\right)$ & (Pu) & (PuO) & $\left(\mathrm{PuO}_{2}\right)$ \\
\hline 1500 & $4.7 \times 10^{-20}$ & $6.0 \times 10^{-15}$ & $5.0 \times 10^{-12}$ & $5.0 \times 10^{-13}$ \\
\hline 1600 & $2.7 \times 10^{-13}$ & $9.6 \times 10^{-15}$ & $6.3 \times 10^{-11}$ & $8.2 \times 10^{-12}$ \\
\hline 1700 & $9.8 \times 10^{-17}$ & $1.1 \times 10^{-13}$ & $5.9 \times 10^{-10}$ & $9.6 \times 10^{-11}$ \\
\hline 1800 & $2.3 \times 10^{-15}$ & $1.0 \times 10^{-12}$ & $4.3 \times 10^{-9}$ & $8.6 \times 10^{-10}$ \\
\hline 1900 & $4.0 \times 10^{-14}$ & $7.2 \times 10^{-12}$ & $2.6 \times 10^{-3}$ & $6.1 \times 10^{-9}$ \\
\hline 2000 & $5.2 \times 10^{-13}$ & $4.2 \times 10^{-11}$ & $1.3 \times 10^{-7}$ & $3.6 \times 10^{-8}$ \\
\hline 2100 & $5.2 \times 10^{-12}$ & $2.1 \times 10^{-10}$ & $5.4 \times 10^{-7}$ & $1.8 \times 10^{-7}$ \\
\hline 2200 & $4.3 \times 10^{-11}$ & $9.1 \times 10^{-10}$ & $2.0 \times 10^{-6}$ & $7.5 \times 10^{-7}$ \\
\hline 2300 & $2.9 \times 10^{-10}$ & $3.5 \times 10^{-9}$ & $6.7 \times 10^{-6}$ & $2.8 \times 10^{-6}$ \\
\hline 2400 & $1.7 \times 10^{-9}$ & $1.2 \times 10^{-8}$ & $2.0 \times 10^{-5}$ & $9.6 \times 10^{-6}$ \\
\hline
\end{tabular}

TABLE A-16

CALCULATED EQUILIBRIUM PARTIAL PRESSURES ABOVE $\left\langle\mathrm{PuO}_{1} \cdot 75>\right.$ (Pressures in Atmospheres)

\begin{tabular}{|c|c|c|c|c|}
\hline Temp. ${ }^{\circ}{ }^{\circ} \mathrm{K}$ & $\left(\mathrm{O}_{2}\right)$ & (Pu) & (PuO) & $\left(\mathrm{PuO}_{2}\right)$ \\
\hline 1500 & $3.5 \times 10^{-21}$ & $6.1 \times 10^{-15}$ & $1.4 \times 10^{-11}$ & $3.7 \times 10^{-13}$ \\
\hline 1600 & $1.6 \times 10^{-19}$ & $1.2 \times 10^{-13}$ & $1.9 \times 10^{-10}$ & $5.9 \times 10^{-12}$ \\
\hline 1700 & $4.0 \times 10^{-18}$ & $1.8 \times 10^{-12}$ & $2.0 \times 10^{-9}$ & $6.8 \times 10^{-11}$ \\
\hline 1800 & $8.8 \times 10^{-17}$ & $1.9 \times 10^{-11}$ & $2.5 \times 10^{-8}$ & $6.0 \times 10^{-10}$ \\
\hline 1900 & $1.3 \times 10^{-15}$ & $1.6 \times 10^{-10}$ & $9.8 \times 10^{-8}$ & $4.2 \times 10^{-9}$ \\
\hline 2000 & $1.4 \times 10^{-14}$ & $1.1 \times 10^{-9}$ & $5.2 \times 10^{-7}$ & $2.4 \times 10^{-8}$ \\
\hline 2100 & $1.2 \times 10^{-13}$ & $6.1 \times 10^{-9}$ & $2.3 \times 10^{-6}$ & $1.2 \times 10^{-7}$ \\
\hline 2200 & $8.7 \times 10^{-13}$ & $2.9 \times 10^{-8}$ & $9.2 \times 10^{-6}$ & $4.9 \times 10^{-7}$ \\
\hline 2300 & $5.2 \times 10^{-12}$ & $1.2 \times 10^{-7}$ & $3.2 \times 10^{-5}$ & $1.8 \times 10^{-6}$ \\
\hline 24 & $2.7 \times 10^{-11}$ & $4.7 \times 10^{-7}$ & $1.0 \times 10^{-4}$ & $6.1 \times 10^{-6}$ \\
\hline
\end{tabular}


TABLE A-17

CALCULATED EQUILIBRIUM PARTIAL PRESSURES ABOVE $\left\langle P_{1} \mathrm{O}_{1 \cdot 70}\right\rangle$ (Pressures in Atmospheres)

\begin{tabular}{cccccc} 
Temp. ${ }^{\circ} \mathrm{K}$ & $\frac{\left(\mathrm{O}_{2}\right)}{2.7 \times 10^{-22}}$ & $\frac{(\mathrm{Pu})}{2.3 \times 10^{-14}}$ & $\frac{(\mathrm{PuO})}{2.4 \times 10^{-11}}$ & $\frac{\left(\mathrm{PuO}_{2}\right)}{3.0 \times 10^{-13}}$ \\
\cline { 2 - 3 } 1500 & $3.1 \times 10^{-20}$ & $4.9 \times 10^{-13}$ & $3.5 \times 10^{-10}$ & $4.8 \times 10^{-12}$ \\
1600 & $8.2 \times 10^{-19}$ & $7.6 \times 10^{-12}$ & $3.6 \times 10^{-9}$ & $5.4 \times 10^{-11}$ \\
1700 & $1.5 \times 10^{-17}$ & $8.6 \times 10^{-11}$ & $2.9 \times 10^{-8}$ & $4.7 \times 10^{-10}$ \\
1800 & $2.0 \times 10^{-16}$ & $7.6 \times 10^{-10}$ & $1.9 \times 10^{-7}$ & $3.3 \times 10^{-9}$ \\
1900 & $5.5 \times 10^{-16}$ & $5.4 \times 10^{-9}$ & $1.0 \times 10^{-6}$ & $1.9 \times 10^{-8}$ \\
2000 & $1.7 \times 10^{-14}$ & $3.2 \times 10^{-8}$ & $4.7 \times 10^{-6}$ & $9.0 \times 10^{-8}$ \\
2100 & $1.2 \times 10^{-13}$ & $1.6 \times 10^{-7}$ & $1.9 \times 10^{-5}$ & $3.7 \times 10^{-7}$ \\
2200 & $6.8 \times 10^{-13}$ & $7.2 \times 10^{-7}$ & $6.7 \times 10^{-5}$ & $1.4 \times 10^{-6}$ \\
2300 & $3.4 \times 10^{-12}$ & $2.8 \times 10^{-6}$ & $2.1 \times 10^{-4}$ & $4.6 \times 10^{-6}$
\end{tabular}

TABLE A-18

CALCULATED EQUILIBRIUM PARTIAL PRESSURES ABOVE <PUO 1 - $85>$ (Pressures in Atmospheres)

\begin{tabular}{|c|c|c|c|c|}
\hline Temp. ${ }^{0}{ }_{k}$ & $\left(O_{2}\right)$ & $(\mathbf{P u})$ & (PuO) & $\left(\mathrm{PuO}_{2}\right)$ \\
\hline 1500 & $2.6 \times 10^{-22}$ & $5.5 \times 10^{-14}$ & $3.5 \times 10^{-11}$ & $2.5 \times 10^{-13}$ \\
\hline 1600 & $1.1 \times 10^{-20}$ & $1.2 \times 10^{-12}$ & $4.9 \times 10^{-10}$ & $4.0 \times 10^{-12}$ \\
\hline 1700 & $3.0 \times 10^{-19}$ & $1.7 \times 10^{-11}$ & $5.1 \times 10^{-9}$ & $4.6 \times 10^{-11}$ \\
\hline 1800 & $5.8 \times 10^{-18}$ & $1.9 \times 10^{-10}$ & $4.1 \times 10^{-8}$ & $4.0 \times 10^{-10}$ \\
\hline 1900 & $8.0 \times 10^{-12}$ & $1.7 \times 10^{-3}$ & $2.6 \times 10^{-7}$ & $2.8 \times 10^{-9}$ \\
\hline 2000 & $8.5 \times 10^{-16}$ & $1.2 \times 10^{-8}$ & $1.4 \times 10^{-8}$ & $1.6 \times 10^{-8}$ \\
\hline 2100 & $7.2 \times 10^{-15}$ & $6.7 \times 10^{-8}$ & $6.4 \times 10^{-6}$ & $7.8 \times 10^{-8}$ \\
\hline 2200 & $5.0 \times 10^{-14}$ & $3.4 \times 10^{-8}$ & $2.5 \times 10^{-5}$ & $3.3 \times 10^{-1}$ \\
\hline 2300 & $2.9 \times 10^{-19}$ & $1.5 \times 10^{-6}$ & $8.9 \times 10^{-5}$ & $1.2 \times 10^{-6}$ \\
\hline 2490 & $1.5 \times 10^{-12}$ & $5.7 \times 10^{-6}$ & $2.8 \times 10^{-4}$ & $4.0 \times 10^{-6}$ \\
\hline
\end{tabular}


CALCULATED EQUILIBRIUM PARTIAL PRESSURES ABOVE $<\mathrm{PuO}_{1 \cdot 61}-\mathrm{PuO}_{1 \cdot 50}>$ (Pressures in Atmospheres)

\begin{tabular}{|c|c|c|c|c|}
\hline Temp., ${ }^{\circ} \mathrm{K}$ & $\left(\mathrm{O}_{2}\right)$ & (Pu) & (PuO) & $\left(\mathrm{PuO}_{2}\right)$ \\
\hline 1500 & $9.2 \times 10^{-23}$ & $1.3 \times 10^{-13}$ & $4.8 \times 10^{-11}$ & $2.1 \times 10^{-13}$ \\
\hline 1600 & $4.4 \times 10^{-21}$ & $2.5 \times 10^{-12}$ & $6.6 \times 10^{-10}$ & $3.4 \times 10^{-12}$ \\
\hline 1700 & $1.3 \times 10^{-19}$ & $3.4 \times 10^{-11}$ & $6.6 \times 10^{-9}$ & $4.0 \times 10^{-11}$ \\
\hline 1800 & $2.8 \times 10^{-18}$ & $3.5 \times 10^{-10}$ & $5.1 \times 10^{-8}$ & $3.5 \times 10^{-10}$ \\
\hline 1900 & $4.2 \times 10^{-17}$ & $2.8 \times 10^{-9}$ & $3.2 \times 10^{-7}$ & $2.5 \times 10^{-9}$ \\
\hline 2000 & $4.7 \times 10^{-16}$ & $1.9 \times 10^{-8}$ & $1.7 \times 10^{-6}$ & $1.4 \times 10^{-8}$ \\
\hline 2100 & $4.3 \times 10^{-15}$ & $1.0 \times 10^{-7}$ & $7.5 \times 10^{-6}$ & $7.1 \times 10^{-8}$ \\
\hline 2200 & $3.2 \times 10^{-14}$ & $4.9 \times 10^{-7}$ & $2.9 \times 10^{-5}$ & $3.0 \times 10^{-7}$ \\
\hline 2300 & $2.0 \times 10^{-13}$ & $2.0 \times 10^{-6}$ & $1.0 \times 10^{-4}$ & $1.1 \times 10^{-6}$ \\
\hline 2400 & $1.1 \times 10^{-12}$ & $7.6 \times 10^{-6}$ & $3.2 \times 10^{-4}$ & $3.8 \times 10^{-6}$ \\
\hline
\end{tabular}

TABIE A-20

CONGRUENTLY VAPORIZING COMPOSITION OF $<\mathrm{PuO}_{2-\mathrm{X}}>$

\begin{tabular}{ccc} 
Temp. ${ }^{\circ}{ }_{\mathrm{K}}$ & $\begin{array}{c}\text { O/Pu } \\
\text { Closed Sjstem }\end{array}$ & $\begin{array}{c}\text { O/Pu } \\
\text { Open System }\end{array}$ \\
\cline { 2 - 3 } 1600 & 1.91 & 1.89 \\
1700 & 1.90 & 1.88 \\
1800 & 1.89 & 1.87 \\
1900 & 1.87 & 1.86 \\
2000 & 1.86 & 1.85 \\
2100 & 1.85 & 1.83 \\
2200 & 1.84 & 1.82
\end{tabular}


TABLE A-21

EXPERIMENTAL VAPOR PRESSURE DATA ABOVE $<\mathrm{PuO}_{2-\mathrm{X}}>$

\begin{tabular}{|c|c|c|c|c|}
\hline Reference & $\begin{array}{c}\text { Temperature } \\
\text { Range, }{ }_{\mathrm{K}} \\
\end{array}$ & Av. ${ }_{\mathrm{O}}^{\text {Temp. }}$ & $\underset{\mathrm{keal} / \mathrm{mole}}{\Delta \mathrm{H}_{\mathrm{T}}^{\mathrm{a}}}$ & $\begin{array}{c}\Delta \mathrm{S}_{\mathrm{T}}{ }^{\mathrm{a}} \\
\end{array}$ \\
\hline 15 & $1650-2070$ & 1900 & 133.9 & 34.3 \\
\hline 17 & $2070-2380$ & 2243 & 141.7 & 38.3 \\
\hline 18 & $1900-2300$ & 2219 & 131.9 & 34.0 \\
\hline 19 & $2000-2200$ & 2110 & 133. 1 & 34.6 \\
\hline $19^{b}$ & $2000-2230$ & 2135 & 129.9 & 32.7 \\
\hline
\end{tabular}

Pressure Values for $\mathbf{P}_{\mathbf{E}}$ in Atmospheres

\begin{tabular}{|c|c|c|}
\hline Reference & $2000^{\circ} \mathrm{K}$ & $2200^{\circ} \mathrm{K}$ \\
\hline 15 & $7.4 \times 10^{-8}$ & $1.6 \times 10^{-6}$ \\
\hline 17 & $7.9 \times 10^{-8}$ & $1.6 \times 10^{-6}$ \\
\hline 18 & $1.0 \times 10^{-7}$ & $2.1 \times 10^{-6}$ \\
\hline 19 & $9.9 \times 10^{-8}$ & $2.1 \times 10^{-6}$ \\
\hline $19^{b}$ & $8.5 \times 10^{-8}$ & $1.7 \times 10^{-6}$ \\
\hline
\end{tabular}

\footnotetext{
${ }^{a}$ The heat and entropy of vaporization terms are based on $P_{E}$ values assuming the vapor to be $\left(\mathrm{PuO}_{2}\right)$.

${ }^{b}$ Sample initially consisted of $\left\langle\mathrm{Pu}_{0 \cdot 45} \mathrm{Th}_{0 \cdot 55} \mathrm{O}_{2 \cdot 0}\right\rangle$.
}

TABLE A-22

COMPARISON OF EXPERIMENTAL AND CALCULATED $P_{E}$ VALUES ABOVE $<\mathrm{PuO}_{2-\mathrm{x}}>$

\begin{tabular}{|c|c|c|c|c|}
\hline Reference & $\begin{array}{l}\text { Av. }{ }_{\mathrm{K}}^{\text {Temp., }} \\
\end{array}$ & $\begin{array}{c}\text { Experimental } \\
\mathbf{P}_{E}(\mathrm{~atm}) \\
\end{array}$ & $\begin{array}{c}\text { Calculatied } \\
\text { Stoichiometry } \\
\end{array}$ & $\begin{array}{r}\text { Calculated } \\
P_{E} \text { (atm) } \\
\end{array}$ \\
\hline 15 & 1900 & $1.3 \times 10^{-8}$ & $\left\langle\mathrm{PuO}_{1 \cdot 86}\right\rangle$ & $1.3 \times 10^{-8}$ \\
\hline 17 & 2243 & $3.7 \times 10^{-6}$ & $\left.<\mathrm{PuO}_{1 \cdot 82}\right\rangle$ & $3.5 \times 10^{-6}$ \\
\hline 18 & 2219 & $2.7 \times 10^{-6}$ & $\left.\left.<\mathrm{PuO}_{1 \cdot 82}\right\rangle\right\rangle$ & $2.4 \times 10^{-6}$ \\
\hline 19 & 2110 & $5.7 \times 10^{-7}$ & $\left.\left.<\mathrm{PuO}_{1 \cdot 89}\right\rangle\right\rangle$ & $4.8 \times 10^{-7}$ \\
\hline
\end{tabular}


EXPERIMENTAL VAPOR PRESSURE DATA ABOVE $<\mathrm{PuO}_{1} \cdot 61-\mathrm{PuO}_{1} \cdot 50>$

\begin{tabular}{|c|c|c|c|c|}
\hline Reference & $\begin{array}{c}\text { Temperature } \\
\text { Range, }{ }_{\mathbf{K}} \\
\end{array}$ & $\begin{array}{l}\text { Av } ._{\mathbf{o}} \text { Temp., } \\
\end{array}$ & $\underset{\mathrm{kcal} / \text { mole }}{\Delta \mathrm{H}_{\mathrm{T}}{ }^{\mathrm{a}}}$ & $\begin{array}{c}\Delta \mathrm{s}_{\mathrm{T}}{ }^{\mathrm{a}} \\
\mathrm{eu}\end{array}$ \\
\hline 15 & $1650-2100$ & 1900 & 127.2 & 37.0 \\
\hline 18 & $1660-2150$ & 2018 & 117.8 & 32.6 \\
\hline $19^{b}$ & $1870-1960$ & 1925 & 127.4 & 37.0 \\
\hline 20 & $1600-2100$ & 1881 & 127.7 & 37.2 \\
\hline
\end{tabular}

Pressure Values for $\mathbf{P}_{\mathbf{E}}$ in Atmospheres

\begin{tabular}{cll} 
Reference & $\frac{1800^{\circ} \mathrm{K}}{4.4 \times 10^{-8}}$ & $\frac{2000^{\circ} \mathrm{K}}{1.5 \times 10^{-6}}$ \\
\hline 15 & $6.6 \times 10^{-8}$ & $1.8 \times 10^{-6}$ \\
18 & $4.2 \times 10^{-8}$ & $1.5 \times 10^{-6}$ \\
$19^{\mathrm{b}}$ & $4.2 \times 10^{-8}$ & $1.5 \times 10^{-6}$ \\
20 & &
\end{tabular}

${ }^{a}$ The heat and entropy terms are based on $\mathbf{P}_{\mathbf{E}}$ values assuming the vapor to be (PuO).

${ }^{b}$ Sample initially consisted of $\left\langle\mathrm{Pu}_{0 \cdot 9} \mathrm{Th}_{0 \cdot 1} \mathrm{O}_{2 \cdot 0}\right\rangle$.

TABLE A-24

COMPARISON OF EXPERIMENTAL AND CALCULATED $P_{E}$ VALUES ABOVE $<\mathrm{PuO}_{1 \cdot 61}-\mathrm{PuO}_{1} \cdot 50>$

\begin{tabular}{|c|c|c|c|}
\hline Reference & $\begin{array}{l}\text { Av. Temp., } \\
{ }_{{ }^{K}}\end{array}$ & $\begin{array}{c}\text { Experimental } \\
\mathbf{P}_{\mathbf{E}} \text { (atm) } \\
\end{array}$ & $\begin{array}{r}\text { Calculated } \\
\mathbf{P}_{\mathbf{E}} \text { (atm) } \\
\end{array}$ \\
\hline 15 & 1900 & $2.9 \times 10^{-7}$ & $3.3 \times 10^{-7}$ \\
\hline 18 & 2018 & $2.3 \times 10^{-6}$ & $2.3 \times 10^{-6}$ \\
\hline 20 & 1881 & $4.3 \times 10^{-7}$ & $5.0 \times 10^{-7}$ \\
\hline
\end{tabular}




\section{TABLE A-25}

THERMODYNAMIC FUNCTIONS FOR SOLID CARBON (GRAPHITE)

\begin{tabular}{|c|c|c|c|}
\hline Temp., ${ }^{\circ}{ }_{K}$ & $\begin{array}{l}\mathrm{H}_{\mathrm{T}}^{0}-\mathrm{H}_{298} \\
\text { cal/mole }\end{array}$ & $\frac{\mathbf{S}_{T}^{0}-\mathbf{S}_{298}^{0}}{\mathrm{eu}^{0}}$ & $\frac{-\left(F_{T}^{0}-H_{298} / T\right)}{e u}$ \\
\hline 298 & 0 & 0.00 & 1.359 \\
\hline 500 & 569 & 1.42 & 1.646 \\
\hline 800 & 1831 & 3.38 & 2.449 \\
\hline 1000 & 2824 & 4.48 & 3.020 \\
\hline 1100 & 3347 & 4.98 & $\mathbf{3 . 3 0 0}$ \\
\hline 1200 & 3883 & 5.45 & 3.573 \\
\hline 1300 & 4432 & 5.89 & 3.839 \\
\hline 1400 & 4988 & 6.30 & 4.098 \\
\hline 1500 & 5552 & 6.69 & 4.348 \\
\hline 1600 & 6122 & 7.06 & 4.591 \\
\hline 1700 & 6696 & 7.41 & 4.827 \\
\hline 1800 & 7275 & 7.74 & 5.055 \\
\hline 1900 & 7857 & 8.05 & 5.276 \\
\hline 2000 & 8442 & 8.35 & 5.490 \\
\hline 2100 & 9029 & 8.64 & 5.698 \\
\hline 2200 & 9620 & 8.91 & 5.900 \\
\hline 2300 & 10212 & 9.18 & 6.095 \\
\hline 2400 & 10807 & 9.43 & 6.286 \\
\hline
\end{tabular}


TABLE A-26

THERMODYNAMIC FUNCTIONS FOR GASEOUS C

\begin{tabular}{|c|c|c|c|c|}
\hline Temp. ${ }^{\circ} \mathrm{K}$ & $\begin{array}{l}\mathrm{H}_{\mathrm{T}}^{0}-\mathrm{H}_{298}^{0} \\
\mathrm{cal} / \mathrm{mole} \\
\end{array}$ & $\begin{array}{c}S_{T}^{0}-S_{298}^{0} \\
\end{array}$ & $\begin{array}{c}-\left(\mathrm{F}_{\mathrm{T}}-\mathbf{H}_{298} / \mathrm{T}\right) \\
\text { eu } \\
\end{array}$ & $\underset{\mathrm{kcal}}{\Delta \mathrm{G}_{\mathrm{f}}}$ mole \\
\hline 298 & 0 & 0.00 & 37.761 & 160.03 \\
\hline 500 & 1004 & 2.57 & 38.325 & 152.55 \\
\hline 800 & 2496 & 4.91 & 39.551 & 141.21 \\
\hline 1000 & 3490 & 6.02 & 40.290 & 133.62 \\
\hline 1100 & 3986 & 6.49 & 40.629 & 129.82 \\
\hline 1200 & 4483 & 6.92 & 40.949 & 126.04 \\
\hline 1300 & 4980 & 7.32 & 41.252 & 122.25 \\
\hline 1400 & 5478 & 7.69 & 41.519 & 118.47 \\
\hline 1500 & 5975 & 8.03 & 41.811 & 114.69 \\
\hline 1600 & 6473 & 8.36 & 42.070 & 110.92 \\
\hline 1700 & 6971 & 8.66 & 42.317 & 107.15 \\
\hline 1800 & 7469 & 8.94 & 42.553 & 103.39 \\
\hline 1900 & 7969 & 9.21 & 42.779 & 99.63 \\
\hline 2000 & 8469 & 9.47 & 42.995 & 95.88 \\
\hline 2100 & 8970 & 9.71 & 43.202 & 92.13 \\
\hline 2200 & 9473 & 9.95 & 43.402 & 88.38 \\
\hline 2300 & 9977 & 10.17 & 43.594 & 84.64 \\
\hline 2400 & 10482 & 10.39 & $43.7 \mathrm{79}$ & 80.90 \\
\hline
\end{tabular}


TABLE A-27

THERMODYNAMTC FUNCTIONS FOR GASEOUS $\mathrm{C}_{2}$

\begin{tabular}{|c|c|c|c|c|}
\hline Temp., ${ }^{\circ} \mathrm{K}$ & $\begin{array}{l}\mathrm{H}_{\mathrm{T}}^{0}-\mathrm{H}_{298}^{0} \\
\mathrm{cal} / \mathrm{mole} \\
\end{array}$ & $\begin{array}{r}\mathbf{S}_{\mathrm{T}}^{0}-\mathbf{S}^{0} \\
\quad 298 \\
\end{array}$ & $\frac{-\left(F_{T}^{0}-H_{298}^{0} / T\right)}{e u}$ & $\underset{\text { kcal }}{\Delta G_{\text {mole }}}$ \\
\hline 298 & 0 & 0.00 & 47.627 & 186.84 \\
\hline 500 & 1924 & 4.96 & 48.740 & 177.50 \\
\hline 800 & 4501 & 9.00 & 51.005 & 163.34 \\
\hline 1000 & 6210 & 10.91 & 52.328 & 153.94 \\
\hline 1100 & 7073 & 11.73 & 52.931 & 149.26 \\
\hline 1200 & 7941 & 12.49 & 53.498 & 144.60 \\
\hline 1300 & 8817 & 13.19 & 54.035 & 139.96 \\
\hline 1400 & 9698 & 13.84 & 54.543 & 135.34 \\
\hline 1500 & 10587 & 14.46 & 55.025 & 130.73 \\
\hline 1600 & 11482 & 15.03 & 55.485 & 126.14 \\
\hline 1700 & 12385 & 15.58 & 55.923 & 121.56 \\
\hline 1800 & 13294 & 16.10 & 56.342 & 117.00 \\
\hline 1900 & 14210 & 16.60 & 56.744 & 112.46 \\
\hline 2000 & 15132 & 17.07 & 57.130 & 107.92 \\
\hline 2100 & 16061 & 17.52 & 57.501 & 103.40 \\
\hline 2200 & 16996 & 17.96 & 57.859 & 98.89 \\
\hline 2300 & 17957 & 18.38 & 58.204 & 94.40 \\
\hline 2400 & 18884 & 18.78 & 58.537 & 89.91 \\
\hline
\end{tabular}




\section{TABLE A-28}

THERMODYNAMIC FUNCTIONS FOR GASEOUS $\mathrm{C}_{3}$

\begin{tabular}{|c|c|c|c|c|}
\hline Temp. ${ }^{o} \mathrm{~K}$ & $\begin{array}{l}\mathrm{H}_{\mathrm{T}}^{0}=\mathrm{H}_{298}^{0} \\
\mathrm{cal} / \mathrm{mole} \\
\end{array}$ & $\frac{\mathrm{S}_{\mathrm{Tu}}^{\mathrm{T}}-\mathrm{S}_{298}^{\mathbf{0}}}{}$ & $\frac{-\left(F_{\mathrm{T}}^{0}-\mathrm{H}_{298}^{0} / \mathrm{T}\right)}{\mathrm{eu}}$ & $\underset{\mathrm{kcal} / \mathrm{G}_{\mathrm{mole}}}{\Delta \mathrm{G}_{\mathrm{e}}}$ \\
\hline 298 & 0 & 0.00 & 56.677 & 180.32 \\
\hline 500 & 1818 & 4.65 & 57.694 & 169.62 \\
\hline 800 & 4716 & 9.18 & 56.957 & 153.92 \\
\hline 1000 & 6804 & 11.90 & 61.375 & 143.68 \\
\hline 1100 & 7887 & 12.53 & 62.041 & 138,64 \\
\hline 1200 & 8992 & 13.50 & 62.679 & 133.65 \\
\hline 1300 & 10116 & 14.40 & 63.291 & 128.69 \\
\hline 1400 & 11258 & 15.24 & 63.877 & 123.78 \\
\hline 1500 & 12415 & 16.04 & 64.440 & 118.91 \\
\hline 1600 & 13586 & 16.80 & 64.981 & 114 . 07 \\
\hline 1700 & 14769 & 17.50 & 65.502 & 109.26 \\
\hline 1800 & 15964 & 18.20 & 66.004 & 104.49 \\
\hline 1900 & 17170 & 18.85 & 66.488 & 99.74 \\
\hline 2000 & 18386 & 19.47 & 66.955 & 95.03 \\
\hline 2100 & 19610 & 20.07 & 67.407 & 90.34 \\
\hline 2200 & 20844 & 20.64 & 67.845 & 85.68 \\
\hline 2300 & 22085 & 21.19 & 68.269 & 81. 04 \\
\hline 2400 & 23333 & 21.72 & 68.680 & 76.43 \\
\hline
\end{tabular}


TABLE A-29

THERMODYNAMIC FUNCTIONS FOR SOIID IRIDIUM

\begin{tabular}{|c|c|c|c|c|}
\hline Temp. ${ }^{\circ} \mathrm{K}$ & $\begin{array}{l}\text { Cp } \\
\text { eut }\end{array}$ & $\begin{array}{l}\mathrm{H}_{\mathrm{T}}^{\mathbf{o}}-\mathbf{H}_{2 \mathrm{AB}}^{\mathbf{o}} \\
\mathrm{cal} / \mathrm{mole} \\
\end{array}$ & $\begin{array}{c}\mathbf{s}_{\mathbf{T}}^{\mathbf{o}}-\mathbf{s}_{298}^{\mathbf{0}} \\
\mathrm{eu} \\
\end{array}$ & $\begin{array}{c}-\left(\mathrm{F}_{\mathrm{T}}^{\mathbf{0}}-\mathrm{H}_{288}^{\mathbf{o}} / \mathrm{T}\right) \\
\mathrm{eu} \\
\end{array}$ \\
\hline 298 & 6.00 & 0 & 0.00 & 8.70 \\
\hline 500 & 6.27 & 1235 & 3.16 & 9.39 \\
\hline 800 & 6.70 & 3190 & 6.22 & 10.94 \\
\hline 1000 & 6.98 & 4545 & 7.73 & 11.89 \\
\hline 1100 & 7.12 & 5250 & 8.40 & 12.33 \\
\hline 1200 & 7.26 & 5970 & 9.03 & 12.76 \\
\hline 1300 & 7.41 & 6700 & 9.61 & 13.16 \\
\hline 1400 & 7.55 & 7440 & 10.16 & 13.55 \\
\hline 1500 & 7.69 & 8200 & 10.68 & 13.92 \\
\hline 1600 & 7.83 & 8980 & 11.19 & 14.28 \\
\hline 1700 & 7.97 & 9780 & 11.67 & 14.62 \\
\hline 1800 & 8.12 & 10590 & 12.13 & 14.95 \\
\hline 1900 & 8.26 & 11410 & 12.57 & 15.27 \\
\hline 2000 & 8.40 & 12240 & 13.00 & 15.58 \\
\hline 2100 & 8.54 & 13090 & 13.41 & 15.88 \\
\hline 2200 & 8.68 & 13950 & 13.81 & 16.17 \\
\hline 2300 & 8.83 & 14820 & 14.20 & 16.46 \\
\hline 2400 & 8.97 & 15710 & 14.58 & 16.74 \\
\hline
\end{tabular}


TABLE A-30

\begin{tabular}{|c|c|}
\hline Temperature, ${ }^{\circ} \mathrm{C}$ & $\begin{array}{l}\text { Solubility, C atoms } \\
\text { per Ir atom }\end{array}$ \\
\hline 700 & $(0.0002)^{b}$ \\
\hline 800 & 0.0003 \\
\hline 900 & 0.0005 \\
\hline 1000 & 0.0007 \\
\hline 1100 & 0.001 \\
\hline 1200 & 0.002 \\
\hline 1300 & $(0.003)$ \\
\hline 1400 & $(0.004)$ \\
\hline 1500 & $(0.007)$ \\
\hline 1600 & $(0.011)$ \\
\hline 1700 & $(0.017)$ \\
\hline 1800 & $(0.027)$ \\
\hline 1900 & $(0.043)$ \\
\hline
\end{tabular}




\section{TABLE A-31}

OXIDATION OF IRIDIUM-RECESSION RATES FROM THE DATA OF KURIAKOSE, KENT AND MARGRAVE

\begin{tabular}{|c|c|c|c|}
\hline Temp. ${ }^{\circ} \mathrm{C}$ & $\begin{array}{l}\text { Oxygen Pressure, } \\
\text { Torr } \\
\end{array}$ & $\begin{array}{l}\text { Gas Velocity } \\
\mathrm{ft} / \mathrm{min}\end{array}$ & $\begin{array}{l}\text { Recession Rate } \\
\mathrm{mil} / \mathrm{h}\end{array}$ \\
\hline 1198 & 152 & $10 *$ & 0.74 \\
\hline 1252 & 152 & 103 & 0.93 \\
\hline 1359 & 152 & 103 & 1.07 \\
\hline \multirow[t]{2}{*}{1487} & 152 & 103 & 1.61 \\
\hline & 15 & 14.7 & 0.07 \\
\hline \multirow{2}{*}{1602} & 152 & 103 & 1.86 \\
\hline & 15 & 14.7 & 0.15 \\
\hline \multirow{2}{*}{1717} & 152 & 103 & 3.40 \\
\hline & 15 & 14.7 & 0.18 \\
\hline \multirow[t]{2}{*}{1830} & 152 & 103 & 5.42 \\
\hline & 15 & 14.7 & 0.40 \\
\hline \multirow[t]{2}{*}{1968} & 152 & 103 & 6.87 \\
\hline & 15 & 14.7 & 0.58 \\
\hline \multirow[t]{2}{*}{2097} & 152 & 103 & 10.98 \\
\hline & 15 & 14.7 & 0.134 \\
\hline \multirow[t]{2}{*}{2217} & 152 & 103 & 13.88 \\
\hline & 15 & 14.7 & 1.15 \\
\hline
\end{tabular}


OXIDATION OF IRIDIUM - RECESSION RATES FROM THE DATA OF REXER

\begin{tabular}{ccccc} 
Temp. ${ }^{\circ} \mathrm{C}$ & $\begin{array}{c}\text { Oxygen Pressure, } \\
\text { Torr }\end{array}$ & 610 & $\begin{array}{c}\text { Gas Velocity } \\
\mathrm{ft} / \mathrm{min}\end{array}$ & $\begin{array}{c}\text { Pecession Rate } \\
\text { mil/h }\end{array}$ \\
\cline { 2 - 2 } 1900 & 142 & 25,000 & 116 \\
& 14.2 & 12,000 & 10.50 \\
1730 & 142 & 12,000 & 0.60 \\
1615 & 142 & 12,000 & 6.42 \\
1500 & 142 & 12,000 & 4.80 \\
1450 & 142 & 12,000 & 3.12 \\
1400 & 142 & 12,000 & 3.96 \\
1330 & 142 & 12,000 & 3.42 \\
1270 & 142 & 12,000 & 2.40 \\
1150 & 142 & 12,000 & 1.86 \\
1500 & 710 & 12,000 & 0.96 \\
1270 & 710 & 25,000 & 47.4 \\
& & 25,000 & 17.4
\end{tabular}

TABLE A-33

RESULTS FOR HEATING PUO 2 -Ir-C ASSEMBLY

Run No.

1

2

3

4

5

2275
Time at

Temp. $\min$.

120

120

5

5

5
Results

Slight sintering of $\mathrm{PuO}_{2}$ particles. No visible reaction bstween $\mathrm{PuO}_{2}$ and $\mathrm{Ir}$ or between $\mathrm{Ir}$ and graphite. Weight loss for assembly was $0.3 \mathrm{mg}$.

Same as for Run No. 1 except further sirtering of $\mathrm{PuO}_{2}$ particles. Weight loss for assembly was $0.5 \mathrm{mg}$.

Same as for Run No. 1. Weight loss for assembly was $0.3 \mathrm{mg}$.

Further sintering of $\mathrm{PuO}_{2}$ particles. Slight sticking of $\mathrm{PuO}_{2}$ to Ir. Iridium stuck tightly to graphite. Weight loss for assembly was 0.7 mg.

Extensive reaction with evolution of gas, presumably CO. Nearly all of the $\mathrm{PuO}_{2}$ and $\mathrm{Ir}$ had reacted with the graphite. Weight loss for the assembly was $140 \mathrm{mg}$. 
TABLE A-34

THERMODYNAMIC FUNCTIONS FOR GASEOUS HYDROGEN

\begin{tabular}{|c|c|c|c|}
\hline Temp. ${ }^{\circ}{ }_{K}$ & $\begin{array}{l}\mathrm{H}_{\mathrm{T}}^{\circ}-\mathrm{H}_{298}^{\circ} \\
\mathrm{cal} / \mathrm{mole} \\
\end{array}$ & $\begin{array}{c}\mathbf{S}_{\mathrm{Tu}}^{\mathbf{o}}-\mathrm{S}_{298}^{\mathbf{o}} \\
\end{array}$ & $\begin{array}{c}-\left(\mathrm{F}_{\mathrm{T}}^{\mathbf{o}}-\mathrm{H}_{298}^{\mathbf{o}} / \mathrm{T}\right) \\
\mathrm{eu} \\
\end{array}$ \\
\hline 298 & 0 & 0.00 & 31.20 \\
\hline 500 & 1406 & 3.60 & 32.00 \\
\hline 800 & 3514 & 6.90 & 33.72 \\
\hline 1000 & 4944 & 8.49 & 34.76 \\
\hline 1100 & 5670 & 9.19 & 35.24 \\
\hline 1200 & 6404 & 9.82 & 35.70 \\
\hline 1300 & 7148 & 10.42 & 36.13 \\
\hline 1400 & 7902 & 10.98 & 36.54 \\
\hline 1500 & 8668 & 11.51 & 36.94 \\
\hline 1600 & 9446 & 12.01 & 37.31 \\
\hline 1700 & 10233 & 12.49 & 37.68 \\
\hline 1800 & 11030 & 12.94 & 38.02 \\
\hline 1900 & 11836 & 13.38 & 38.36 \\
\hline 2000 & 12651 & 13.80 & 38.68 \\
\hline 2100 & 13475 & 14.20 & 38.99 \\
\hline 2200 & 14307 & 14.58 & 39.29 \\
\hline 2300 & 15146 & 14.96 & 39.58 \\
\hline 2400 & 15993 & 15.32 & 39.86 \\
\hline
\end{tabular}


TABLE A-35

THERMODYNAMIC FLNCTIONS FOR GASEOUS WATER

\begin{tabular}{|c|c|c|c|}
\hline Temp., ${ }^{\circ} \mathrm{K}$ & $\begin{array}{l}\mathbf{H}_{\mathbf{T}}^{\mathbf{O}}-\mathbf{H}_{298}^{\mathbf{O}} \\
\text { cal/mole } \\
\end{array}$ & $\begin{array}{c}S_{\mathrm{T}}^{0}-\mathbf{S}_{288}^{0} \\
\end{array}$ & $\frac{-\left(F_{\mathbf{T}}^{\mathbf{o}}-\dot{\mathrm{H}}_{298}^{\mathbf{0}} / \mathbf{T}\right)}{\mathrm{eu}}$ \\
\hline 298 & 0 & 0.00 & 45.11 \\
\hline 500 & 1654 & 4.23 & 46.03 \\
\hline 800 & 4300 & 8.36 & 48.09 \\
\hline 1000 & 6209 & 10.49 & 49.38 \\
\hline 1100 & 7210 & 21.44 & 49.99 \\
\hline 1200 & 8240 & 12.34 & 50.58 \\
\hline 1300 & 9298 & 13.18 & 51.14 \\
\hline 1400 & 10384 & 13.99 & 51.68 \\
\hline 1500 & 11495 & 14.75 & 52.20 \\
\hline 1600 & 12630 & 15.48 & 52.70 \\
\hline 1700 & 13787 & 16.19 & 53.18 \\
\hline 1800 & 14964 & 16.86 & 53.65 \\
\hline 1900 & 16160 & 17.51 & 54.11 \\
\hline 2000 & 17373 & 18.13 & 54.55 \\
\hline 2100 & 18602 & 18.73 & 54.98 \\
\hline 2200 & 19846 & 19.31 & 55.39 \\
\hline 2300 & 21103 & 19.86 & 55.80 \\
\hline 2400 & 22372 & 20.40 & 56.19 \\
\hline
\end{tabular}


TABLE A-36

THERMODYNAMIC FUNCTIONS FOR GASEOUS CO

\begin{tabular}{|c|c|c|c|c|}
\hline Temp. ${ }^{{ }^{0}}$ & $\begin{array}{l}\mathrm{H}_{\mathrm{T}}^{\mathbf{O}}-\mathrm{H}_{298}^{\mathbf{o}} \\
\text { cal/mole } \\
\end{array}$ & $\mathbf{s}_{T_{\text {ex }}^{0}-s_{2:}^{0}}^{0}$ & $\frac{-\left(\mathrm{F}_{\mathrm{T}}^{0}-\mathbf{H}_{\mathrm{ZB}}^{0} / \mathrm{T}\right)}{\mathrm{eu}}$ & $\begin{array}{l}\Delta \mathrm{G}_{\mathrm{f}} \\
\mathrm{kcal} / \mathrm{mole}\end{array}$ \\
\hline $29 \dot{8}$ & 0 & 0.00 & 47.21 & -32.78 \\
\hline 500 & 1417 & 3.68 & 48.01 & -37.14 \\
\hline 800 & 3627 & 7.08 & 49.76 & -43.61 \\
\hline 1000 & 5183 & 8.81 & 50.84 & -47.86 \\
\hline 1100 & 5983 & 9.58 & 51.35 & -49.96 \\
\hline 1200 & 6794 & 10.28 & 51.83 & -52.05 \\
\hline 1300 & 7616 & 10.94 & 52.30 & -54.13 \\
\hline 1400 & 8446 & 11.56 & 52.74 & -56.19 \\
\hline 1500 & 9285 & 1213 & 53.16 & -58.24 \\
\hline 1600 & 10130 & 12.68 & 53.56 & -60.28 \\
\hline 1700 & 10980 & 13.20 & 53.95 & -62.32 \\
\hline 1800 & 11836 & 13.68 & 54.32 & $-64 . \Sigma 1$ \\
\hline 1900 & 12697 & 14.15 & 54.68 & -66.35 \\
\hline 2000 & 13561 & 14.59 & 55.03 & -68.35 \\
\hline 2100 & 14430 & 15.02 & 55.36 & -70.35 \\
\hline 2200 & 15301 & 15.42 & 55.68 & -72.34 \\
\hline 2300 & 16175 & 15.81 & 55.99 & -74.31 \\
\hline 2400 & 17052 & 16.18 & 56.29 & -76.28 \\
\hline
\end{tabular}


TABLE A-37

THERMODYNAMIC FUNCTIONS FOR GASEOUS $\mathrm{CO}_{2}$

\begin{tabular}{|c|c|c|c|c|}
\hline Temp., ${ }^{{ }^{\circ}} \mathrm{K}$ & $\begin{array}{l}\mathrm{H}_{\mathrm{T}}^{\mathbf{0}}-\mathrm{H}_{298}^{\mathbf{0}} \\
\mathrm{cal} / \mathrm{mole} \\
\end{array}$ & $\mathrm{s}_{\mathrm{Tu}}^{\mathbf{0}}-\mathbf{s}_{298}^{\mathbf{0}}$ & $\begin{array}{c}-\left(\mathbf{F}_{\mathrm{T}}^{\mathbf{o}}-\mathbf{H}_{298}^{\mathrm{O}} / \mathrm{T}\right) \\
\mathbf{\in u} \\
\end{array}$ & $\underset{\mathrm{knOM} / \mathrm{mole}}{\Delta G_{\mathrm{f}}}$ \\
\hline 298 & 0 & 0.00 & 51.08 & -94.26 \\
\hline 500 & 1987 & 5.05 & 52.15 & -94.40 \\
\hline 800 & 5453 & 10.45 & 54.71 & -94.56 \\
\hline 1000 & 7984 & 13.27 & 56.36 & -94.63 \\
\hline 1100 & 9296 & 24.52 & 57.14 & -94.66 \\
\hline 1200 & 10632 & 15.68 & 57.90 & -94.68 \\
\hline 1300 & 11988 & 16.77 & 58.62 & -94.70 \\
\hline 1400 & 13362 & 17.79 & 59.32 & -94.72 \\
\hline 1500 & 14750 & 18.74 & 59.98 & -94.73 \\
\hline 1600 & 16152 & 19.65 & 60.63 & -94.74 \\
\hline 1700 & 17565 & 20.51 & 61.25 & -94.75 \\
\hline 1800 & 18987 & 21.32 & 61.84 & -94.75 \\
\hline 1900 & 20418 & 22.09 & 62.42 & -94.75 \\
\hline 2000 & 21857 & 22.83 & 62.97 & -94.75 \\
\hline 2100 & 23303 & 23.54 & 63.51 & -94.75 \\
\hline 2200 & 24755 & 24.21 & 64.03 & -94.74 \\
\hline 2300 & 26212 & 24.86 & 64.54 & -94.74 \\
\hline 2400 & 27674 & 25.48 & 65.02 & -94.72 \\
\hline
\end{tabular}


APPENDIX B

CALCULATED REACTIONS

TABLE B- 1

REACTIONS BETWEEN $<\mathrm{PuO}_{2}>$ and $<\mathrm{C}>$ at $298^{\circ} \mathrm{K}$

Reaction

\begin{tabular}{|c|c|c|c|c|c|}
\hline $\mathrm{PuO}_{2}>$ & $+0.02\langle\mathrm{C}\rangle$ & $=\left\langle\mathrm{PuO}_{1} \cdot 98\right\rangle$ & + & $0.02(\mathrm{CO})$ & 1.75 \\
\hline $\mathrm{PuO}_{2}>$ & $+0.05<C>$ & $=\left\langle\mathrm{PuO}_{1} \cdot{ }_{95}\right\rangle$ & + & $0.05(\mathrm{CO})$ & 3.95 \\
\hline $\mathrm{FuO}_{2}>$ & $+0.08<\mathrm{C}\rangle$ & $=\left\langle\mathrm{PuO}_{1} \cdot 92\right\rangle$ & + & 0.08 & 6.02 \\
\hline $\mathrm{PuO}_{2}>$ & $+0.10<\mathrm{C}>$ & $=\left\langle\mathrm{PuO}_{1} \cdot 30\right\rangle$ & + & $0.10(\mathrm{CO})$ & 7.35 \\
\hline $\mathrm{PuO}_{2}>$ & $+0.15<C\rangle$ & $=\left\langle\mathrm{PuO}_{1} \cdot 85\right\rangle$ & + & $0.15(\mathrm{CO})$ & +10.63 \\
\hline $\mathrm{PuO}_{2} \mathrm{>}$ & $+0.20<C\rangle$ & $=\left\langle\mathrm{PuO}_{1} \cdot \mathrm{gD}\right\rangle$ & + & 0.20 & +13.63 \\
\hline $\mathrm{PuO}_{2}>$ & $+0.25<\mathrm{C}\rangle$ & $=\left\langle\mathrm{PuO}_{1 \cdot 75}\right\rangle$ & + & 0.25 & +16.36 \\
\hline $\mathrm{PuO}_{2}>$ & $+0.30<C>$ & $=\left\langle\mathrm{PuO}_{1} \cdot \mathrm{TO}_{0}\right\rangle$ & + & $0.30(\mathrm{CO})$ & +18.05 \\
\hline $\mathrm{PuO}_{2}>$ & $+0.35<C>$ & $=\left\langle\mathrm{PuO}_{1} \cdot 65\right\rangle$ & + & $0.35(\mathrm{CO})$ & +21.66 \\
\hline $\mathrm{PuO}_{2}>$ & $+0.39<C>$ & $=\left\langle\mathrm{PuO}_{1} \cdot 6 \mathrm{t}\right\rangle$ & $t$ & $0.39(\mathrm{CO})$ & +23.83 \\
\hline $\mathrm{PuO}_{2}>$ & $+0.50<C>$ & $=\left\langle\mathrm{PuO}_{1} \cdot 50\right\rangle$ & + & $0.50(\mathrm{CO})$ & +29.62 \\
\hline $\mathrm{PuO}_{2}>$ & $+2.0<\mathrm{C}\rangle$ & $=(\mathrm{Pu})$ & & $2.0 \quad(\mathrm{CO})$ & +246.2 \\
\hline $\mathrm{PuO}_{2}>$ & $+2.9<\mathrm{C}>$ & $=\left\langle\mathrm{PuC}_{0} \cdot 9\right\rangle$ & + & $2.0 \quad(\mathrm{CO})$ & +160.2 \\
\hline & $+3.5<C>$ & $=\left\langle\mathrm{PuC}_{1}\right.$. & + & $2.0 \quad(\mathrm{CO})$ & +157.2 \\
\hline $\mathrm{uO}_{2}>$ & $+2.0<C>$ & $=\left\langle\mathrm{PuO}_{0.5} \mathrm{C}_{0.5}\right\rangle$ & + & $1.5(\mathrm{CO})$ & +126.2 \\
\hline
\end{tabular}

$\Delta G$

$\mathrm{kcal} /$ mole

1.75

7.35

36

18.05

62

126.2

TAELE B-2

REACTIONS BETWEEN $<\mathrm{PuO}_{2}>$ and $<\mathrm{C}>$ at $500{ }^{\circ} \mathrm{K}$

Reaction

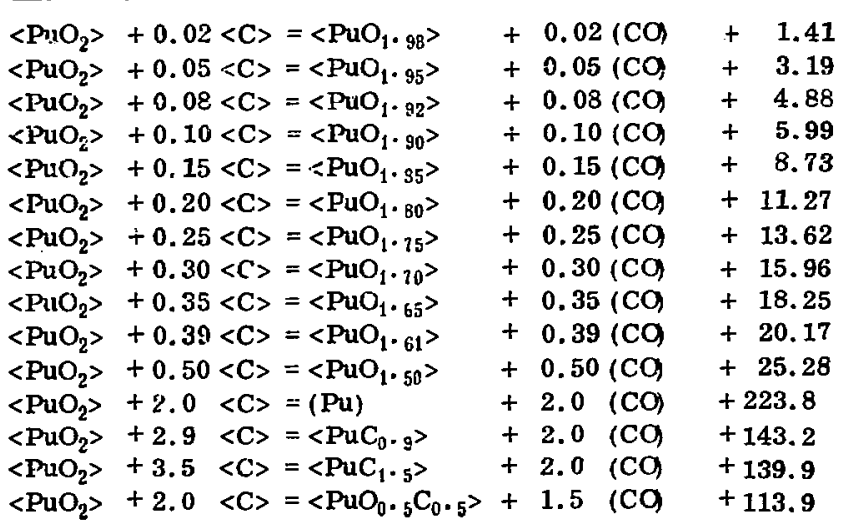


REACTIONS BETWEEN $<\mathrm{PuO}_{2}>$ and $\langle\mathrm{C}\rangle$ at $800^{\circ} \mathrm{K}$

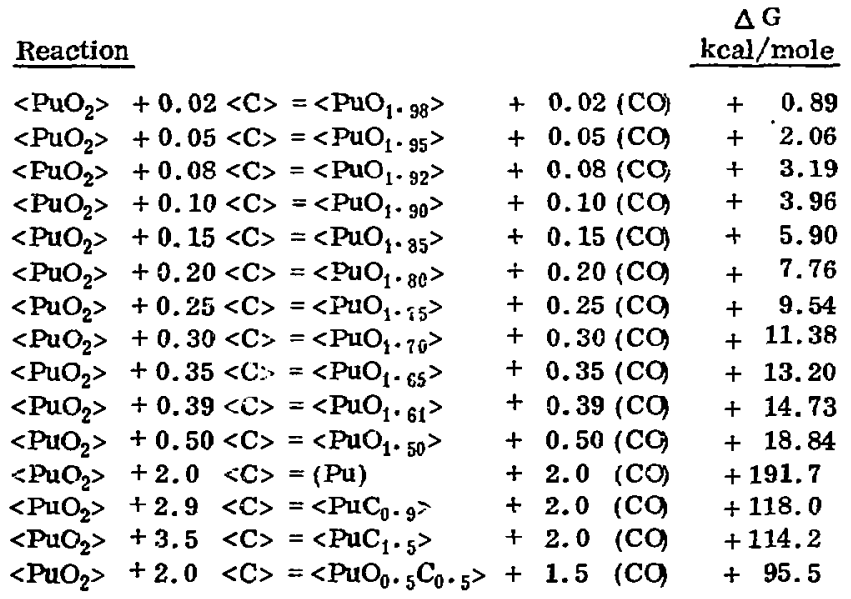

TABLE B-4

REACTIONS BETWEEN $<$ PuO $_{2}>$ and $<$ C $>$ at $1000^{\circ} \mathrm{K}$

Reaction

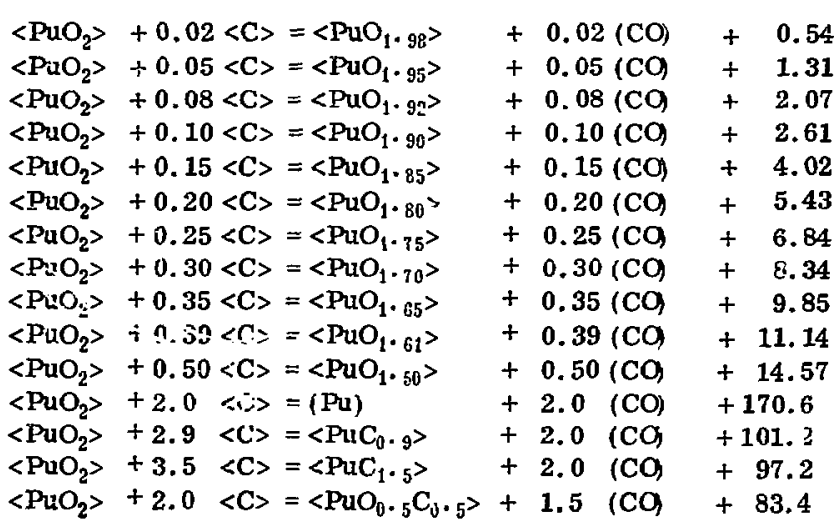


REACTIONS BETWEEN $<\mathrm{PuO}_{2}>$ and $<\mathrm{C}>$ at $1100{ }^{\circ} \mathrm{K}$

Reaction

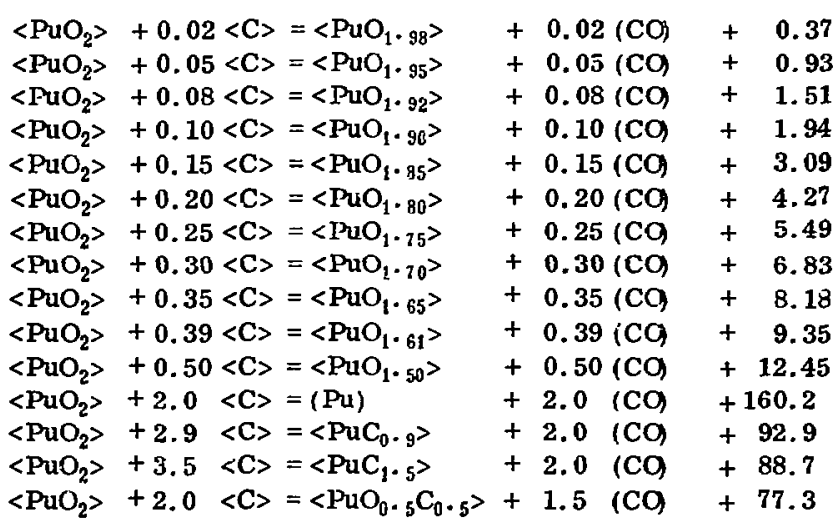

$\triangle \mathrm{G}$ $\mathrm{kcal} / \mathrm{mole}$

37

51

1.94

.49

35

92.9

77.3

\section{TABLE B-6}

REACTIONS BETWEEN $<\mathrm{PuO}_{2}>$ and $<\mathrm{C}>$ at $1200^{\circ} \mathrm{K}$

Reaction

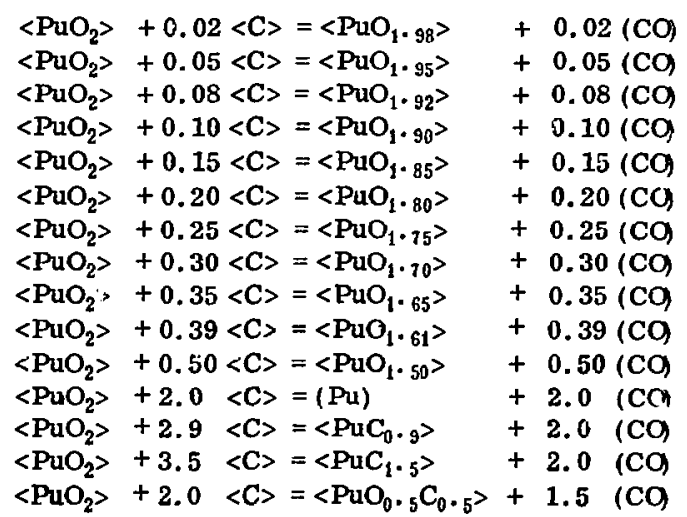

$\Delta \mathrm{G}$

$\mathrm{kcal} / \mathrm{mole}$

$+\quad 0.20$

$+\quad 0.56$

$+\quad 0.96$

$+1.28$

$+2.15$

$+3.11$

$+4.15$

$+\quad 5.32$

$+\quad 6.52$

$+7.56$

$+10.34$

$+149.8$

$+84.7$

$+80.3$

$+71.4$ 
TABLE B-7

REACTIONS BETWEEN $\left\langle\mathrm{PuO}_{2}\right\rangle$ and $\left\langle\mathrm{C}>\right.$ at $1300^{\circ} \mathrm{K}$

\begin{tabular}{|c|c|c|c|c|}
\hline \multicolumn{4}{|l|}{ Reaction } & $\begin{array}{c}\Delta \mathrm{G} \\
\mathrm{kcal} / \mathrm{mole}\end{array}$ \\
\hline$\left.<\mathrm{PuO}_{2}\right\rangle$ & $+0.02\langle\mathrm{C}\rangle=\left\langle\mathrm{PuO}_{1 \cdot 98}\right\rangle$ & + & $0.02(\mathrm{CO})$ & 0.03 \\
\hline$\left\langle\mathrm{PuO}_{2}\right\rangle$ & $+0.05\langle\mathrm{C}\rangle=\left\langle\mathrm{PuO}_{1} \cdot 95\right\rangle$ & + & $0.05(\mathrm{CO})$ & 0.18 \\
\hline$\left.<\mathrm{FuO}_{2}\right\rangle$ & $+0.08\langle\mathrm{C}\rangle=\left\langle\mathrm{PuO}_{1} \cdot \mathrm{g}_{2}\right\rangle$ & + & $0.08(\mathrm{CO})$ & 0.40 \\
\hline$\left.<\mathrm{PuO}_{2}\right\rangle$ & $+0.10\langle\mathrm{C}\rangle=\left\langle\mathrm{PuO}_{1 \cdot 90}\right\rangle$ & + & $0.10(\mathrm{CO})$ & 0.61 \\
\hline$\left\langle\mathrm{PuO}_{2}\right\rangle$ & $+0.15<\mathrm{C}\rangle=\left\langle\mathrm{PuO}_{2 \cdot 85}\right\rangle$ & + & $0.15(\mathrm{CO})$ & 1.22 \\
\hline$\left.<\mathrm{PuO}_{2}\right\rangle$ & $+0.20<\mathrm{C}\rangle=\left\langle\mathrm{PuO}_{1} \cdot 80\right\rangle$ & + & $0.20(\mathrm{CO})$ & 1,95 \\
\hline$\left\langle\mathrm{PuO}_{2}\right\rangle$ & $+0.25\langle\mathrm{C}\rangle=\left\langle\mathrm{PuO}_{1} \cdot 75\right\rangle$ & + & $0.25(\mathrm{CO})$ & 2.81 \\
\hline$\left\langle\mathrm{PuO}_{2}\right\rangle$ & $+0.30<\mathrm{C}\rangle=\left\langle\mathrm{PuO}_{1} \cdot 70\right\rangle$ & + & $0.30(\mathrm{CO})$ & 3.82 \\
\hline$\left\langle\mathrm{PuO}_{2}\right\rangle$ & $+0.35<\mathrm{C}\rangle=\left\langle\mathrm{PuO}_{1 \cdot 65}\right\rangle$ & + & $0.35(\mathrm{CO})$ & 4.86 \\
\hline$\left\langle\mathrm{PuO}_{2}\right\rangle$ & $+0.39<\mathrm{C}\rangle=\left\langle\mathrm{PuO}_{1} \cdot{ }_{61}\right\rangle$ & $\div$ & 0.39 (CO) & 5.78 \\
\hline$\left\langle\mathrm{PuO}_{2}\right\rangle$ & $+0.50\langle\mathrm{C}\rangle=\left\langle\mathrm{PuO}_{1} \cdot 50\right\rangle$ & $\dot{+}$ & $0.50(\mathrm{CO})$ & 8.22 \\
\hline$\left\langle\mathrm{PuO}_{2}\right\rangle$ & $+2.0<\mathrm{C}\rangle=(\mathrm{Pu})$ & $\div$ & $2.0 \quad(\mathrm{CO})$ & +143.8 \\
\hline$\left\langle\mathrm{PuO}_{2}\right\rangle$ & $+2.9\langle\mathrm{C}\rangle=\left\langle\mathrm{PuC}_{0.9}\right\rangle$ & + & $2.0 \quad(\mathrm{CO})$ & +76.4 \\
\hline$\left\langle\mathrm{PuO}_{2}\right\rangle$ & $+3.5\langle\mathrm{C}\rangle=\left\langle\mathrm{PuC}_{1 \cdot 5}\right\rangle$ & + & $2.0 \quad(\mathrm{CO})$ & +71.9 \\
\hline$\left\langle\mathrm{PuO}_{2}\right\rangle$ & $+2.0<\mathrm{C}\rangle=\left\langle\mathrm{PuO}_{0} \cdot{ }_{5} \mathrm{C}_{0} \cdot{ }_{5}\right\rangle$ & + & $1.5 \quad(\mathrm{CO}$ & +65.4 \\
\hline
\end{tabular}

TABLE B-8

REACTIONS BETWEEN $<\mathrm{PuO}_{2}>$ and $<\mathrm{C}>$ at $1400^{\circ} \mathrm{K}$

Reaction

$\left\langle\mathrm{PuO}_{2}\right\rangle+0.02\langle\mathrm{C}\rangle=\left\langle\mathrm{PuO}_{1} \cdot 98\right\rangle$ $\left\langle\mathrm{PuO}_{2}\right\rangle+0.05\langle\mathrm{C}\rangle=\left\langle\mathrm{PuO}_{1} \cdot 95\right\rangle$ $\left\langle\mathrm{PuO}_{2}\right\rangle+0.08\langle\mathrm{C}\rangle=\left\langle\mathrm{PuO}_{1} \cdot 92\right\rangle$ $\left\langle\mathrm{PuO}_{2}\right\rangle+0.10\langle\mathrm{C}\rangle=\left\langle\mathrm{PuO}_{1} \cdot 90\right\rangle$ $\left\langle\mathrm{PuO}_{2}\right\rangle+0.15\langle\mathrm{C}\rangle=\left\langle\mathrm{PuO}_{1} \cdot 85\right\rangle$ $\left\langle\mathrm{PuO}_{2}\right\rangle+0.20\langle\mathrm{C}\rangle=\left\langle\mathrm{PuO}_{1} \cdot \varepsilon 0\right\rangle$ $\left\langle\mathrm{PuO}_{2}\right\rangle+0.25\langle\mathrm{C}\rangle=\left\langle\mathrm{PuO}_{1.75}\right\rangle$ $\left.\left\langle\mathrm{PuO}_{2}\right\rangle+0.30<\mathrm{C}\right\rangle=\left\langle\mathrm{PuO}_{1} \cdot 70^{2}\right\rangle$ $\left\langle\mathrm{PuO}_{2}\right\rangle+0.35\langle\mathrm{C}\rangle=\left\langle\mathrm{PuO}_{1.65}\right\rangle$ $\left\langle\mathrm{PuO}_{2}\right\rangle+0.39\langle\mathrm{C}\rangle=\left\langle\mathrm{PuO}_{1} \cdot 61\right\rangle$ $\left\langle\mathrm{PuO}_{2}\right\rangle+0.50\langle\mathrm{C}\rangle=\left\langle\mathrm{PuO}_{1} \cdot 50\right\rangle$ $\left.\left\langle\mathrm{PuO}_{2}\right\rangle+2.0<\mathrm{C}\right\rangle=(\mathrm{Pu})$ $\left\langle\mathrm{PuO}_{2}\right\rangle+2.9\langle\mathrm{C}\rangle=\left\langle\mathrm{PuC}_{\mathrm{f}} . \mathrm{g}\right\rangle$ $\left\langle\mathrm{PuO}_{2}\right\rangle+3.5\langle\mathrm{C}\rangle=\left\langle\mathrm{PuC}_{1.5}\right\rangle$ $\left\langle\mathrm{PuO}_{2}\right\rangle+2.0\langle\mathrm{C}\rangle=\left\langle\mathrm{PuO}_{0} \cdot{ }_{5} \mathrm{C}_{0} \cdot 5\right\rangle$ $\triangle G$

$\mathrm{kcal} / \mathrm{mole}$

$+0.02(\mathrm{CO})$

$+0.05(\mathrm{CO})$

$-0.14$

$-\quad 0.19$

$+0.08(\mathrm{CO}-0.16$

$+0.10(\mathrm{CO}-0.06$

$+0.15(\mathrm{CO})+0.29$

$+0.20(\mathrm{CO}+0.80$

$+0.251 \mathrm{CO}+1.47$

$+0.30(\mathrm{CO})+2.32$

$+0.35(\mathrm{CO}+3.21$

$+0.39(\mathrm{CO}+4.01$

$+0.50(\mathrm{CO}+6.12$

$+2.0(\mathrm{CO})+129.0$

$+2.0(\mathrm{CO})+68.2$

+2.0 (CO) +63.5

+1.5 (CO)

$+59.4$ 
TABLE B-9

REACTIONS BETWFEN $<\mathrm{PuO}_{2}>$ aind $<\mathrm{C}>$ at $1500{ }^{\circ} \mathrm{K}$

Reaction

\begin{tabular}{|c|c|c|c|c|}
\hline$\left.<\mathrm{PuO}_{2}\right\rangle$ & $+0.02<\mathrm{C}>$ & $=\left\langle\mathrm{PuO}_{1} \cdot \mathrm{Q}_{8}\right\rangle$ & + & \\
\hline$\left\langle\mathrm{PuO}_{2}\right\rangle$ & $+0.05<\mathrm{C}>$ & $=\left\langle\mathrm{PuO}_{1} \cdot{ }_{95}\right\rangle$ & + & $0.05(\mathrm{C}$ \\
\hline $\mathrm{PuO}_{2}>$ & $+0.08<C>$ & $=\left\langle\mathrm{PuO}_{1}-\jmath_{2}\right\rangle$ & + & $0.08(\mathrm{CC}$ \\
\hline $\mathrm{PrO}_{2}>$ & $+0.10<C>$ & $=\left\langle\mathrm{PuO}_{1} \cdot 90^{\prime}\right\rangle$ & + & $0.10(\mathrm{CC}$ \\
\hline $\mathrm{PuO}_{2}>$ & $+0.15\langle\mathrm{C}\rangle$ & $=\left\langle\mathrm{PuO}_{1 \cdot 85}\right\rangle$ & + & $0.15(\mathrm{CC}$ \\
\hline $\mathrm{PuO}_{2}>$ & $+0.20<C>$ & $=\left\langle\operatorname{Pu} O_{1} \cdot 80\right\rangle$ & + & $0.20(\mathrm{CO})$ \\
\hline$\left.<\mathrm{PuO}_{2}\right\rangle$ & $+0.25<\mathrm{C}\rangle$ & $=\left\langle\mathrm{PuO}_{1 \cdot 75}\right\rangle$ & + & $0.25(\mathrm{CO})$ \\
\hline$\left\langle\mathrm{PuO}_{2}\right\rangle$ & $+0.30<\mathrm{C}\rangle$ & $=\left\langle\mathrm{PuO}_{1 \cdot ? 0}\right\rangle$ & + & $0.30(\mathrm{CO})$ \\
\hline$\left\langle\mathrm{PuO}_{2}\right\rangle$ & $+0.35<\mathrm{C}\rangle$ & $=\left\langle\mathrm{PuO}_{1} \cdot \mathrm{GS}_{5}\right\rangle$ & + & $0.35(\mathrm{CO})$ \\
\hline$\left\langle\mathrm{PuO}_{2}\right\rangle$ & $+0.39<\mathrm{C}\rangle$ & $=\left\langle\mathrm{PuO}_{1} \cdot \mathrm{G}_{1}\right\rangle$ & + & $0.39(\mathrm{CO})$ \\
\hline$\left\langle\mathrm{PuO}_{2}\right\rangle$ & $+0.50<\mathrm{C}\rangle$ & $=\left\langle\mathrm{PuO}_{1 \cdot 50}\right\rangle$ & + & $0.50(\mathrm{CO})$ \\
\hline $\mathrm{PuO}_{2}>$ & $+2.0<\mathrm{C}>$ & $=(\mathrm{Pu})$ & + & $2.0 \quad(\mathrm{C}$ \\
\hline$\left\langle\mathrm{PuO}_{2}\right\rangle$ & $+2.9<\mathrm{C}>$ & $=\left\langle P u C_{0} \cdot 9\right\rangle$ & + & $2.0<\mathrm{C}$ \\
\hline$\left\langle\mathrm{PuO}_{2}\right\rangle$ & $+3.5<\mathrm{C}>$ & $=\left\langle\cdot \mathrm{PuC}_{1} \cdot \mathrm{s}_{3}\right\rangle$ & & $2.0 i \mathrm{CO}$ \\
\hline$\left\langle\mathrm{PuO}_{2}\right\rangle$ & $+2.0<\mathrm{C}>$ & $=<\mathrm{PuO}_{0} \cdot{ }_{5} \mathrm{C}_{0}$. & + & $1.5)(\mathrm{CC}$ \\
\hline
\end{tabular}

$\Delta \mathrm{G}$

$\mathrm{kcal} / \mathrm{mole}$

$-0.31$

$-0.56$

$-0.71$

$-0.72$

$-\quad 0.64$

$-0.35$

$+0.14$

$+\quad 0.83$

$+\quad 1.57$

$+2.24$

$+4.03$

$+118.7$

$+60.0$

$+55.2$

$+53.4$

TABLF $\mathbf{D - 1 0}$

REACTIONS BETWEEN $<\mathrm{PuO}_{2}>$ and $<\mathrm{C}>$ at. $1600^{\circ} \mathrm{K}$

\section{Reaction}

$\left\langle\mathrm{PuO}_{2}\right\rangle+0.02\langle\mathrm{C}\rangle=\left\langle\mathrm{PuO}_{1} \cdot 98\right\rangle$ $\left\langle\mathrm{PuO}_{2}\right\rangle+0.05\langle\mathrm{C}\rangle=\left\langle\mathrm{PuO}_{1} \cdot 95\right\rangle$ $\left\langle\mathrm{PuO}_{2}\right\rangle+0.08\langle\mathrm{C}\rangle=\left\langle\mathrm{PuO}_{1} \cdot 92\right\rangle$ $\left.\left\langle\mathrm{PuO}_{2}\right\rangle+0.10<\mathrm{C}\right\rangle=\left\langle\mathrm{PuO}_{1} \cdot 90\right\rangle$ $\left\langle\mathrm{PuO}_{2}\right\rangle+0.15\langle\mathrm{C}\rangle=\left\langle\mathrm{PuO}_{1} \cdot 85\right\rangle$ $\left\langle\mathrm{PuO}_{2}\right\rangle+0.20\langle\mathrm{C}\rangle=\left\langle\mathrm{PuO}_{1} \cdot 80\right\rangle$ $\left\langle\mathrm{PuO}_{2}\right\rangle+0.25\langle\mathrm{C}\rangle=\left\langle\mathrm{PuO}_{1} \cdot 75\right\rangle$ $\left\langle\mathrm{PuO}_{2}\right\rangle+0.30\langle\mathrm{C}\rangle=\left\langle\mathrm{PuO}_{1} \cdot 70\right\rangle$ $\left\langle\mathrm{PuO}_{2}\right\rangle+0.35\langle\mathrm{C}\rangle=\left\langle\mathrm{PuO}_{1 \cdot 65}\right\rangle$ $\left\langle\mathrm{PuO}_{2}\right\rangle+0.39\langle\mathrm{C}\rangle=\left\langle\mathrm{PuO}_{1.61}\right\rangle$ $\left\langle\mathrm{PuO}_{2}\right\rangle+0.50\langle\mathrm{C}\rangle=\left\langle\mathrm{PuO}_{1} \cdot 50\right\rangle$ $\left\langle\mathrm{PuO}_{2}\right\rangle+2.0\langle\mathrm{C}\rangle=(\mathrm{Pu})$ $\left\langle\mathrm{PuO}_{2}\right\rangle+2.9\langle\mathrm{C}\rangle=\left\langle\mathrm{PuC}_{0.9}\right\rangle$ $\left\langle\mathrm{PuO}_{2}\right\rangle+3.5\langle\mathrm{C}\rangle=\left\langle\mathrm{PuC}_{1} \cdot 5\right\rangle$ $\left.\left\langle\mathrm{PuO}_{2}\right\rangle+2.0<\mathrm{C}\right\rangle=\left\langle\mathrm{PuO}_{0 .} \mathrm{C}_{0.5}\right\rangle$

$\Delta \mathrm{G}$

kcal $/$ mole

$+0.02(\mathrm{CO})$

$+0.05(\mathrm{CO})$

$+0.08(\mathrm{CO})$

$+0.10(\mathrm{CO})$

$+0.15(\mathrm{CO})$

$+0.20(\mathrm{CO}$

$+0.251 \mathrm{CO}$

$+0.30(\mathrm{CO})$

$+0.35 \mathrm{lCO}$

+0.39 (CO

$+0.50(\mathrm{CO})$

+2.0 (CO)

+2.0 (CO)

$+2.0 \mathrm{iCO}$

+1.5 (CO)
- 0.49

- 0.93

- 1.26

- 1.39

- 1.56

- 1.50

- 1.19

- 0.66

- 0.08

$+\quad 0.47$

$+\quad 1.94$

$+108.3$

$+51.8$

$+46.8$

$+47.5$ 
REACTIONS BETWEEN $<\mathrm{PuO}_{2}>$ and $<\mathrm{C}>$ at $1700^{\circ} \mathrm{K}$

\section{Reaction}

$\left\langle\mathrm{PuO}_{2}\right\rangle+0.02\langle\mathrm{C}\rangle=\left\langle\mathrm{PuO}_{1} \cdot 98\right\rangle$ $\left\langle\mathrm{PuO}_{2}\right\rangle+0.05\langle\mathrm{C}\rangle=\left\langle\mathrm{PuO}_{1} \cdot 95\right\rangle$ $\left\langle\mathrm{PuO}_{2}\right\rangle+0.08\langle\mathrm{C}\rangle=\left\langle\mathrm{PuO}_{1} \cdot \mathrm{g}_{2}\right\rangle$ $\left.\left\langle\mathrm{PuO}_{2}\right\rangle+0.10<\mathrm{C}\right\rangle=\left\langle\mathrm{PuO}_{1} \cdot 90\right\rangle$ $\left\langle\mathrm{PuO}_{2}\right\rangle+0.15\langle\mathrm{C}\rangle=\left\langle\mathrm{PuO}_{1} \cdot 85\right\rangle$ $\left.\left\langle\mathrm{PuO}_{\mathrm{i}}\right\rangle+0.20<\mathrm{C}\right\rangle=\left\langle\mathrm{PuO}_{1} \cdot 80\right\rangle$ $\left\langle\mathrm{PuO}_{2}\right\rangle+0.25\langle\mathrm{C}\rangle=\left\langle\mathrm{PuO}_{1 \cdot 75}\right\rangle$ $\left.\left\langle\mathrm{PuO}_{2}\right\rangle+0.30<\mathrm{C}\right\rangle=\left\langle\mathrm{PuO}_{1 \cdot 70}\right\rangle$ $\left\langle\mathrm{PuO}_{2}\right\rangle+0.35\langle\mathrm{C}\rangle=\left\langle\mathrm{PuO}_{1} \cdot 65\right\rangle$ $\left\langle\mathrm{PuO}_{2}\right\rangle+0.39\langle\mathrm{C}\rangle=\left\langle\mathrm{PuO}_{1} \cdot 61\right\rangle$ $\left\langle\mathrm{PuO}_{2}\right\rangle+0.50\langle\mathrm{C}\rangle=\left\langle\mathrm{PuO}_{1} \cdot 50\right\rangle$ $\left.\left\langle\mathrm{PuO}_{2}\right\rangle+2.0<\mathrm{C}\right\rangle=(\mathrm{Pu})$ $\left.\left\langle\mathrm{PuO}_{2}\right\rangle+2.9<\mathrm{C}\right\rangle=\left\langle\mathrm{PuC}_{0} \cdot 9\right\rangle$ $\left.\left\langle\mathrm{PuO}_{2}\right\rangle+3.5<\mathrm{C}\right\rangle=\left\langle\mathrm{PuC}_{1} \cdot 5\right\rangle$ $\left.\left\langle\mathrm{PuO}_{2}\right\rangle+2.0<\mathrm{C}\right\rangle=\left\langle\mathrm{PuO}_{3} \mathrm{C} \mathrm{C}_{0.5}\right\rangle+1.5$
$\Delta G$

$\mathrm{kcal} / \mathrm{mole}$

$+0.02(\mathrm{CO})$

$+0.05(\mathrm{CO})$

$+0.08(\mathrm{CO})$

$+0.10(\mathrm{CO})$

$+0.15(\mathrm{CO})$

$+0.20(\mathrm{CO})$

$+0.25(\mathrm{CO}$

$+0.30(\mathrm{CO})$

$+0.35(\mathrm{CO})$

$+0.39(\mathrm{CO})$

$+0.50(\mathrm{CO}$

$+2.0(\mathrm{CO})$

$+2.01 \mathrm{CO}$

+2.0 (CO)

$-0.66$

- 1.31

- 1.82

$-2.05$

- 2.49

- 2.64

- 2.52

$-2.16$

- 1.72

$-1.29$

- 0.15

$+98.0$

$+43.6$

$+38.5$

$+41.6$

TABLE B-12

REACTIONS BETWEEN $<\mathrm{PuO}_{2}>$ and $<\mathrm{C}>$ at $1800^{\circ} \mathrm{K}$

Reaction

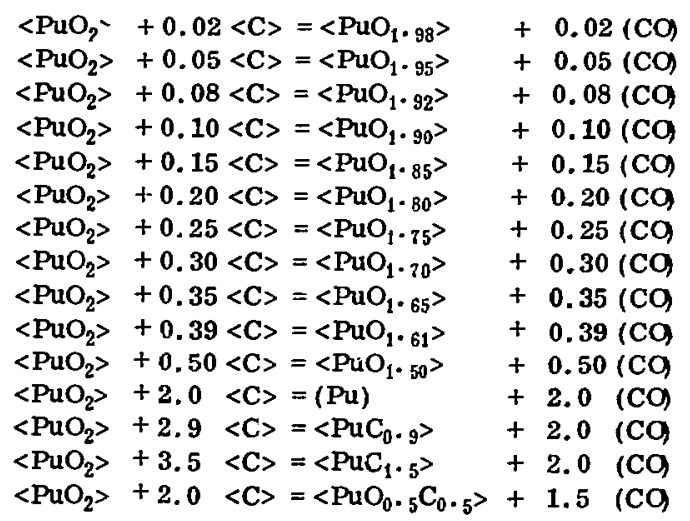

$\Delta \mathbf{G}$

kcal/mole

0.83
$-\quad 1.68$

- 1.68

- 2.37

- 2.71

- 3.41

-3.79
$-\quad 3.88$

- 3.84

- 3.64

- 3.36

- 3.05

- 2.23

$+87.7$

$+35.5$

$+30.2$

$+35.6$ 
REACTIONS BETWEEN $<\mathrm{PuO}_{2}>$ and $<$ C $>$ at $1900{ }^{\circ} \mathrm{K}$

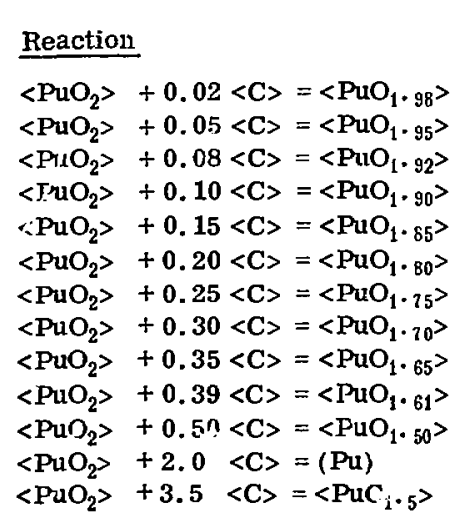

\begin{tabular}{|c|c|c|}
\hline & & $\begin{array}{c}\Delta G \\
\mathrm{kcal} / \mathrm{mole}\end{array}$ \\
\hline+ & $0.02(\mathrm{CO})$ & 1.00 \\
\hline+ & $0.05(\mathrm{CO})$ & 2.05 \\
\hline & $0.08(\mathrm{CO})$ & 2.92 \\
\hline & $0.10(\mathrm{CO})$ & 3.38 \\
\hline & $0.15(\mathrm{CO})$ & 4.33 \\
\hline & $0.20(\mathrm{CO})$ & 4.93 \\
\hline & $0.25(\mathrm{CO})$ & 5.17 \\
\hline & $0.30(\mathrm{CO})$ & 5.12 \\
\hline & $0.35(\mathrm{CO})$ & $-\quad 4.99$ \\
\hline & 0.39 (CO & $-\quad 4.81$ \\
\hline & $0.50(\mathrm{CQ})$ & -4.30 \\
\hline & $2.0 \quad(\mathrm{CO})$ & +77.4 \\
\hline & $2.0 \quad(\mathrm{CO})$ & +22.0 \\
\hline
\end{tabular}

TABLE B-14

REACTIONS BETWEEN $<\mathrm{PuO}_{2}>$ an $\mathrm{A}<\mathrm{C}>$ at $2000^{\circ} \mathrm{K}$

\section{Reaction}

$\left\langle\mathrm{PuO}_{2}\right\rangle+0.02\langle\mathrm{C}\rangle=\left\langle\mathrm{PuO}_{1 \cdot 98}\right\rangle$ $\left.\left\langle\mathrm{PuO}_{2}\right\rangle+0.05<\mathrm{C}\right\rangle=\left\langle\mathrm{PuO}_{1} \cdot .55\right\rangle$ $\left.\left\langle\mathrm{PuO}_{2}\right\rangle+0.08<\mathrm{C}\right\rangle=\left\langle\mathrm{PuO}_{1 \cdot 92}\right\rangle$ $\left.\left\langle\mathrm{PuO}_{2}\right\rangle+0.10<\mathrm{C}\right\rangle=\left\langle\mathrm{PuO}_{1} \cdot 90\right\rangle$ $\left\langle\mathrm{PuO}_{2}\right\rangle+0.15\langle\mathrm{C}\rangle=\left\langle\mathrm{PuO}_{1} \cdot 85\right\rangle$ $\left\langle\mathrm{PuO}_{2}\right\rangle+0.20\langle\mathrm{C}\rangle=\left\langle\mathrm{PuO}_{1} \cdot 80\right\rangle$ $\left\langle\mathrm{PuO}_{2}\right\rangle+0.25\langle\mathrm{C}\rangle=\left\langle\mathrm{PuO}_{1} \cdot 75\right\rangle$ $\left\langle\mathrm{PuO}_{2}\right\rangle+0.30\langle\mathrm{C}\rangle=\left\langle\mathrm{PuO}_{1 \cdot 70}\right\rangle$ $\left\langle\mathrm{PuO}_{2}\right\rangle+0.35\langle\mathrm{C}\rangle=\left\langle\mathrm{PuO}_{1} \cdot 65\right\rangle$ $\left\langle\mathrm{PuO}_{2}\right\rangle+0.39\langle\mathrm{C}\rangle=\left\langle\mathrm{PuO}_{1} \cdot{ }_{61}\right\rangle$ $\left\langle\mathrm{PuO}_{2}\right\rangle+0.50\langle\mathrm{C}\rangle=\left\langle\mathrm{PuO}_{1} \cdot 50\right\rangle$ $\left.\left\langle\mathrm{PuO}_{2}\right\rangle+2.0<\mathrm{C}\right\rangle=(\mathrm{Pu})$ $\left.\left\langle\mathrm{PuO}_{2}\right\rangle+4.0<\mathrm{C}\right\rangle=\left\langle\mathrm{PuC}_{2}\right\rangle$
$\Delta \mathrm{G}$

$\mathrm{kcal} / \mathrm{mole}$

$+0.02(\mathrm{CO})-1.17$

$+0.05(\mathrm{CO})-2.42$

$+0.08(\mathrm{CO})-3.47$

$+0.10(\mathrm{CO}-4.04$

$+0.15(\mathrm{CO})-5.25$

$+0.20(\mathrm{CO}-6.07$

$+0.25(\mathrm{Ca}-6.49$

$+0.30(\mathrm{CO}-6.60$

$+0.35(\mathrm{CO})-6.62$

$+0.39(\mathrm{CO}-6.56$

$+0.50(\mathrm{CO}-6.38$

$+2.0(\mathrm{CO})+67.0$

$+2.0(\mathrm{CO})+13.5$ 
TABLE B- 15

REACTIONS BETWEEN $<\mathrm{PuO}_{2}>$ and $<\mathrm{C}>$ at $2100{ }^{\circ} \mathrm{K}$

\section{Reaction}

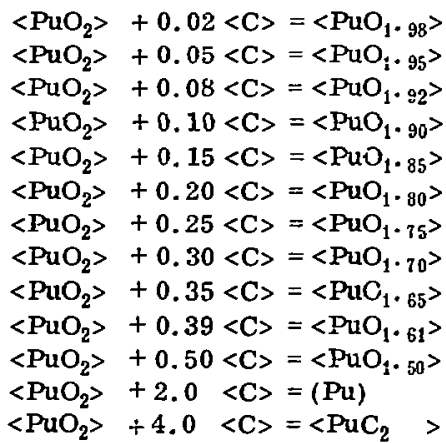

$\Delta \mathrm{G}$

$\underline{\mathrm{kcal} / \mathrm{mole}}$

$+0.02(\mathrm{CO})-1.34$
$+0.05(\mathrm{CO})-2.79$
$+0.08(\mathrm{CO})-4.02$
$+0.10(\mathrm{CO})-4.70$
$+0.15(\mathrm{CO})-6.17$
$+0.20(\mathrm{CO})-7.21$
$+0.25(\mathrm{CO}-7.81$
$+0.30(\mathrm{CO})-8.08$
$+0.35(\mathrm{CO})-8.25$
$+0.39(\mathrm{CO}-8.31$
$+0.50(\mathrm{CO}-8.44$
$+2.0(\mathrm{CO})+56.7$
$+2.0(\mathrm{CO})+4.9$

TABLE B-16

REACTIONS BETWEEN $<\mathrm{PuO}_{2}>$ and $<\mathrm{C}>$ at $2200^{\circ} \mathrm{K}$

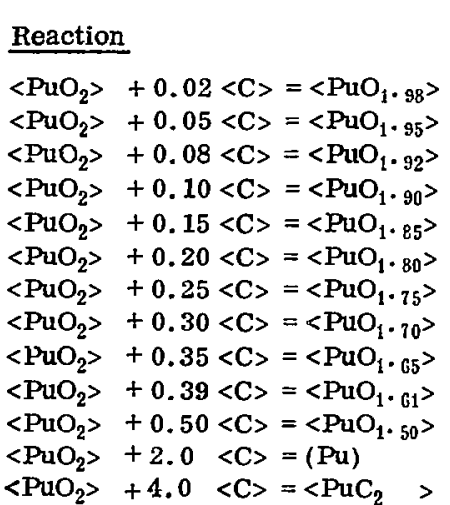

$\triangle \mathrm{G}$ $\mathrm{kcal} / \mathrm{mole}$

$+0.02(\mathrm{CO})-1.51$

$+0.05(\mathrm{CO}-3.16$

$+0.08(\mathrm{CO}-4.57$

$+0.10(\mathrm{CO})-5.35$

$+0.15(\mathrm{CO})-7.09$

$+0.20(\mathrm{CO}-8.35$

$+0.25(\mathrm{CO}-9.12$

$+0.30(\mathrm{CO})-9.56$

$+0.35(\mathrm{CO}-9.88$

$+0.39(\mathrm{CO}-10.05$

$+0.50(\mathrm{CO}-10.51$

$+2.0(\mathrm{CO})+46.4$

$+2.0(\mathrm{CO})-3.7$ 
REACTIONS BETWEEN $<\mathrm{PuO}_{2}>$ and $<\mathrm{C}>$ at $2300^{\circ} \mathrm{K}$

\begin{tabular}{|c|c|c|c|c|}
\hline \multicolumn{4}{|l|}{$\underline{\text { Reaction }}$} & $\begin{array}{c}\Delta \mathrm{G} \\
\mathrm{kcal} / \mathrm{mole}\end{array}$ \\
\hline$\left\langle\mathrm{PuO}_{2}\right\rangle$ & $+0.02<\mathrm{C}\rangle=\left\langle\mathrm{PuO}_{1 \cdot 98}\right\rangle$ & + & $0.02(\mathrm{CO})$ & -1.68 \\
\hline$\left\langle\mathrm{PuO}_{2}\right\rangle$ & $+0.05\langle\mathrm{C}\rangle=\left\langle\mathrm{PuO}_{1} \cdot .95\right\rangle$ & + & $0.05(\mathrm{CO})$ & -3.53 \\
\hline$\left\langle\mathrm{FuO}_{2}\right\rangle$ & $+0.08\langle\mathrm{C}\rangle=\left\langle\mathrm{PuO}_{1} \cdot 92\right\rangle$ & + & $0.08(\mathrm{CO})$ & -5.11 \\
\hline$\left.<\mathrm{PuO}_{2}\right\rangle$ & $+0.10\langle\mathrm{C}\rangle=\left\langle\mathrm{PuO}_{1 \cdot 90}\right\rangle$ & + & $0.10(\mathrm{CO})$ & -6.01 \\
\hline$\left\langle\mathrm{PuO}_{2}\right\rangle$ & $+0.15\langle\mathrm{C}\rangle=\left\langle\mathrm{PuO}_{9.85}\right\rangle$ & + & $0.15(\mathrm{CO})$ & -8.01 \\
\hline$\left\langle\mathrm{PuO}_{2}\right\rangle$ & $+0.20<\mathrm{C}\rangle=\left\langle\mathrm{PuO}_{1 \cdot 80}\right\rangle$ & + & $0.20(\mathrm{Ca}$ & -9.48 \\
\hline$\left\langle\mathrm{PuO}_{2}\right\rangle$ & $+0.25\langle\mathrm{C}\rangle=\left\langle\mathrm{PuO}_{1 \cdot 75}\right\rangle$ & + & $0.25(\mathrm{CO}$ & -10.44 \\
\hline$\left\langle\mathrm{PuO}_{2}\right\rangle$ & $+0.30<\mathrm{C}\rangle=\left\langle\mathrm{PuO}_{1 \cdot 70}\right\rangle$ & + & $0.30(\mathrm{CO})$ & -11.03 \\
\hline$\left\langle\mathrm{PuO}_{2}\right\rangle$ & $+0.35<\mathrm{C}\rangle=\left\langle\mathrm{PuO}_{1} \cdot 65\right\rangle$ & + & $0.35(\mathrm{CO})$ & -11.50 \\
\hline$\left\langle\mathrm{PuO}_{2}\right\rangle$ & $+0.39<\mathrm{C}\rangle=\left\langle\mathrm{PuO}_{1 \cdot 61}\right\rangle$ & + & $0.39(\mathrm{CO})$ & -11.79 \\
\hline$\left\langle\mathrm{PuO}_{2}\right\rangle$ & $+0.50\langle\mathrm{C}\rangle=\left\langle\mathrm{PuO}_{1} \cdot 50\right\rangle$ & + & $0.50(\mathrm{CO}$ & -12.56 \\
\hline$\left\langle\mathrm{PuO}_{2}\right\rangle$ & $+2.0<\mathrm{C}>=(\mathrm{Pu})$ & + & $2.0(\mathrm{CO})$ & +36.1 \\
\hline$\left\langle\mathrm{FuO}_{2}\right\rangle$ & $+4.0<\mathrm{C}\rangle=\left\langle\mathrm{PuC}_{2}\right.$ & + & $2.0(\mathrm{co})$ & -12.2 \\
\hline
\end{tabular}

TABLE B - 18

REACTIONS BETWEEN $<\mathrm{PuO}_{2}>$ and $(\mathrm{CO})$ at $298 \%$

$\underline{\text { Reaction }}$

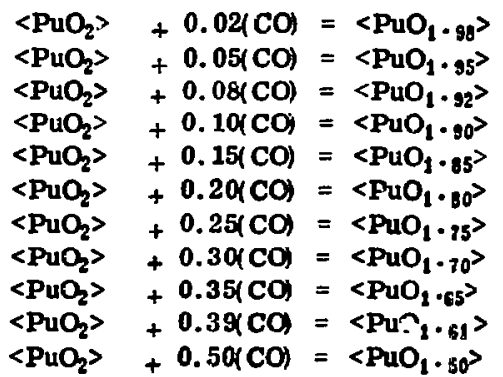

$\triangle \mathbf{G}$

$\mathrm{kcal} / \mathrm{mole}$

$\begin{array}{rlll}+0.02 & \left(\mathrm{CO}_{2}\right) & + & 1.18 \\ +0.05 & \left(\mathrm{CO}_{2}\right) & + & 2.52 \\ +0.08 & \left(\mathrm{CO}_{2}\right) & + & 3.72 \\ +0.10 & \left(\mathrm{CO}_{2}\right) & + & 4.48 \\ +0.15 & \left(\mathrm{CO}_{2}\right) & + & \mathbf{6 . 3 3} \\ +0.20 & \left(\mathrm{CO}_{2}\right) & + & 7.89 \\ +0.25 & \left(\mathrm{CO}_{2}\right) & + & 9.19 \\ +0.30 & \left(\mathrm{CO}_{2}\right) & + & 10.44 \\ +0.35 & \left(\mathrm{CO}_{2}\right) & + & 11.61 \\ +0.39 & \left(\mathrm{CO}_{2}\right) & + & 12.63 \\ +0.50 & \left(\mathrm{CO}_{2}\right) & + & 15.27\end{array}$


REACTIONS BETWEEN $<\mathrm{PUO}_{2}>$ and $(\mathrm{CO})$ at $500^{\circ} \mathrm{K}$

Reaction

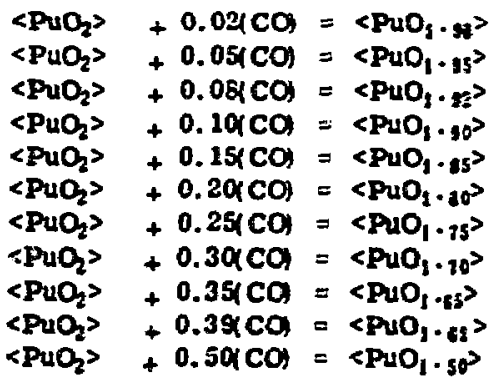

${ }^{C}$

keal/mole

+0.02
+0.05
+0.08
+0.10
+0.15
+0.20
+0.25
+0.30
+0.35
+0.39
+0.50

(CO)

$(\mathrm{CO})$

$(\mathrm{Co})$

(co)

$\left(\mathrm{CO}_{2}\right)$

$\left(\mathrm{CO}_{2}\right)$

$\left(\mathrm{CO}_{2}\right)$

$\left(\mathrm{CO}_{2}\right)$

$\left(\mathrm{CO}_{2}\right)$

$(\mathrm{CO})$

(CO)

+1.00
$+\quad 2.19$
$+\quad 3.27$
$+\quad 3.97$
$+\quad 5.71$
$+\quad 7.25$
$+\quad 9.58$
$+\quad 9.92$
$+\quad 12.21$
$+\quad 12.32$
$+\quad 15.22$

TABEE $\mathbf{B}-20$

REACTIONS BETWEEN <PUO $>$ and $(C O$ at sofK

Bencellon

$\Delta 0$

\begin{tabular}{|c|c|c|c|c|c|}
\hline 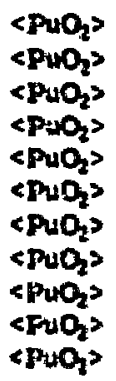 & $\begin{array}{l}+0.02 \mathrm{co} \\
+0.05 \mathrm{co} \\
+0.04 \mathrm{co} \\
+0.10 \mathrm{co} \\
+0.15 \mathrm{co} \\
+0.20 \mathrm{co} \\
+0.35 \mathrm{co} \\
+0.34 \mathrm{ca} \\
+0.35 \mathrm{co} \\
+0.34 \mathrm{co} \\
+0.3 \mathrm{co}\end{array}$ & 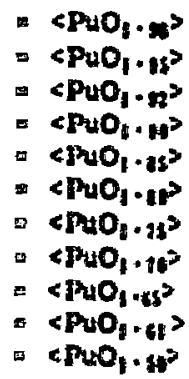 & $\begin{array}{l}+0.02 \\
+0.05 \\
+0.08 \\
+0.20 \\
+0.15 \\
+0.20 \\
+0.25 \\
+0.30 \\
+0.35 \\
+0.35 \\
+0.30\end{array}$ & $\begin{array}{l}(\mathrm{CO}) \\
(\mathrm{CO}) \\
(\mathrm{CO}) \\
\left(\mathrm{CO}_{2}\right) \\
(\mathrm{CO}) \\
(\mathrm{CO}) \\
(\mathrm{CO}) \\
(\mathrm{CO}) \\
(\mathrm{CO}) \\
(\mathrm{CO}) \\
(\mathrm{CO})\end{array}$ & $\begin{array}{r}+0.79 \\
+\quad 1.69 \\
+\quad 2.60 \\
+\quad 9.22 \\
+\quad 4.81 \\
+\quad 6.29 \\
+\quad 9.70 \\
+\quad 9.18 \\
+\quad 10.161 \\
+\quad 11.67 \\
+\quad 16.16\end{array}$ \\
\hline
\end{tabular}


REACTIONS BETWEEN $<\mathrm{PUO}_{2}>$ and $(\mathrm{CO})$ at $1000^{\circ} \mathrm{K}$

Feaction

\begin{tabular}{|c|c|c|c|c|c|}
\hline 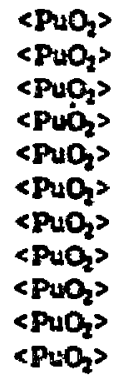 & $\begin{array}{l}+0.021 \mathrm{ca} \\
+0.051 \mathrm{co} \\
+0.081 \mathrm{co} \\
+0.101 \mathrm{co} \\
+0.151 \mathrm{CO} \\
+0.20 \mathrm{co} \\
+0.25 \mathrm{co} \\
+0.30 \mathrm{co} \\
+0.35 \mathrm{co} \\
+0.39 \mathrm{ca} \\
+0.54 \mathrm{co}\end{array}$ & 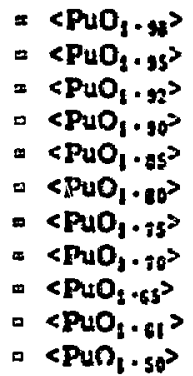 & $\begin{array}{l}+0.02 \\
+0.05 \\
+0.08 \\
+0.10 \\
+0.15 \\
+0.20 \\
+0.25 \\
+0.30 \\
+0.35 \\
+0.39 \\
+0.50\end{array}$ & 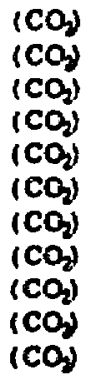 & $\begin{array}{r}+\quad 0.56 \\
+\quad 1.36 \\
+\quad 2.16 \\
+\quad 2.72 \\
+\quad 1.18 \\
+\quad 5.65 \\
+\quad 7.11 \\
+\quad 8.67 \\
+\quad 10.23 \\
+\quad 11.56 \\
+\quad 10.12\end{array}$ \\
\hline
\end{tabular}

$\Delta^{G}$ keal/mole

36

72

23

5. 12

TABLE B - 22

REACTIONS BETWEEN $<\mathrm{PuO}_{2}>$ and $(\mathrm{CO})$ at $1100^{\circ} \mathrm{K}$

Reacuon

\begin{tabular}{|c|c|c|c|c|c|}
\hline 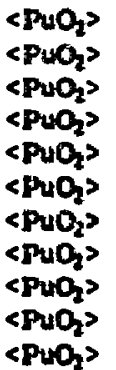 & 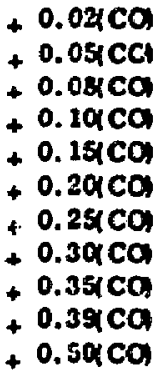 & 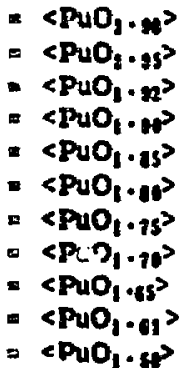 & $\begin{array}{l}+0.02 \\
+0.05 \\
+0.08 \\
+0.10 \\
+0.15 \\
+0.20 \\
+0.25 \\
+0.30 \\
+0.35 \\
+0.39 \\
+0.50\end{array}$ & $\begin{array}{l}(\mathrm{CO}) \\
(\mathrm{CO}) \\
\left(\mathrm{CO}_{2}\right) \\
\left(\mathrm{CO}_{2}\right) \\
\left(\mathrm{CO}_{2}\right) \\
\left(\mathrm{CO}_{2}\right) \\
\left(\mathrm{CO}_{1}\right) \\
\left(\mathrm{CO}_{2}\right) \\
\left(\mathrm{CO}_{2}\right) \\
\left(\mathrm{CO}_{2}\right) \\
\left(\mathrm{CO}_{2}\right)\end{array}$ & $\begin{array}{r}+\quad 0.48 \\
+\quad 1.20 \\
+\quad 1.93 \\
+\quad 2.47 \\
+\quad 3.88 \\
+\quad 5.32 \\
+\quad 6.80 \\
+\quad 8.41 \\
+\quad 10.02 \\
+\quad 11.40 \\
+\quad 15.08\end{array}$ \\
\hline
\end{tabular}


Reaction

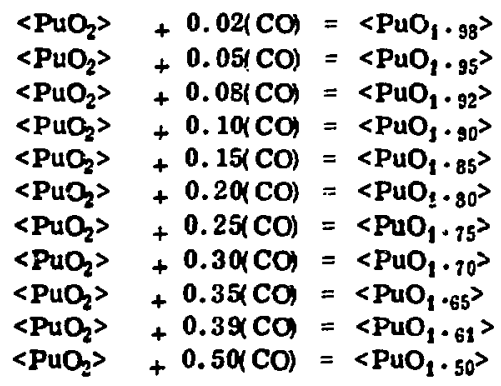

$\Delta^{\mathrm{G}}$

$\mathrm{kcal} / \mathrm{mole}$

$$
\begin{aligned}
& +0.02 \\
& +0.05 \\
& +0.08 \\
& +0.10 \\
& +0.15 \\
& +0.20 \\
& +0.25 \\
& +0.30 \\
& +0.35 \\
& +0.39 \\
& +0.50
\end{aligned}
$$

$\begin{array}{lll}\left(\mathrm{CO}_{2}\right) & + & 0.39 \\ \left(\mathrm{CO}_{2}\right) & + & 1.03 \\ \left(\mathrm{CO}_{2}\right) & + & 1.71 \\ \left(\mathrm{CO}_{2}\right) & + & 2.22 \\ \left(\mathrm{CO}_{2}\right) & + & 3.57 \\ \left(\mathrm{CO}_{2}\right) & + & 4.99 \\ \left(\mathrm{CO}_{2}\right) & + & 6.50 \\ \left(\mathrm{CO}_{2}\right) & + & 8.15 \\ \left(\mathrm{CO}_{2}\right) & + & 9.82 \\ \left(\mathrm{CO}_{2}\right) & + & 11.23 \\ \left(\mathrm{CO}_{2}\right) & + & 15.04\end{array}$

REACTIONS BETWEEN $<\mathrm{PUO}_{2}>$ and $(\mathrm{CO})$ at $1300^{\circ} \mathrm{K}$

Reaction

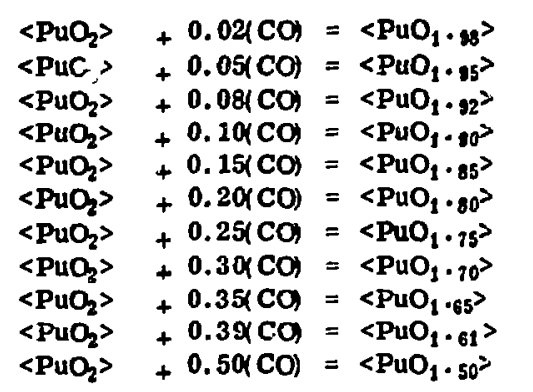

$\Delta \mathbf{G}$

kcal/mole

+0.02
+0.05
+0.08
+0.10
+0.15
+0.20
+0.25
+0.30
+0.35
+0.39
+0.50

$\left(\mathrm{CO}_{2}\right)$

$\left(\mathrm{CO}_{2}\right)$

$\left(\mathrm{CO}_{2}\right)$

$\left(\mathrm{CO}_{2}\right)$

$\left(\mathrm{CO}_{2}\right)$

$\left(\mathrm{CO}_{2}\right)$

$\left(\mathrm{CO}_{2}\right)$

$\left(\mathrm{Cu}_{2}\right)$

$\left(\mathrm{CO}_{2}\right)$

$\left(\mathrm{CO}_{2}\right)$

$\left(\mathrm{CO}_{2}\right)$
0.30

$+\quad 0.86$

$+\quad 1.48$

$+\quad 1.96$

3.25
$+\quad 4.67$

$+\quad 4.67$

$+\quad 6.20$
$+\quad 9.89$

$+\quad 7.89$

$+\quad 9.61$

$+11.07$

$+15.00$ 
TABLE B -25

REACTIONS BETWEEN $<\mathrm{F} \cdot \mathrm{uO}_{2}>$ and $(\mathrm{CO})$ at $1400 \%$

Reaction

$$
\begin{aligned}
& \left\langle\mathrm{PuC}_{2}\right\rangle+0.02(\mathrm{CO})=\left\langle\mathrm{PuO}_{1} \cdot \mathrm{ga}_{\mathrm{a}}\right\rangle \\
& \left\langle\mathrm{PuO}_{2}\right\rangle+0.05(\mathrm{CO})=\left\langle\mathrm{PuO}_{1} \cdot 95\right\rangle \\
& \left\langle\mathrm{PuO}_{2}\right\rangle+0.08(\mathrm{CO})=\left\langle\mathrm{PuO}_{1} \cdot 92\right\rangle \\
& \left\langle\mathrm{PuO}_{2}\right\rangle+0.10(\mathrm{CO})=\left\langle\mathrm{PuO}_{1} \cdot 90\right\rangle \\
& \left\langle\mathrm{PuO}_{2}\right\rangle+0.15(\mathrm{CO})=\left\langle\mathrm{PuO}_{1} \cdot 85\right\rangle \\
& \left\langle\mathrm{PuO}_{2}\right\rangle+0.20(\mathrm{CO})=\left\langle\mathrm{PuO}_{1} \cdot 80\right\rangle \\
& \left\langle\mathrm{FuO}_{2}\right\rangle+0.25(\mathrm{CO})=\left\langle\mathrm{PuO}_{1} \cdot 7 \mathrm{~T}\right\rangle \\
& \left\langle\mathrm{PuO}_{2}\right\rangle+0.30(\mathrm{CO})=\left\langle\mathrm{PuO}_{1} \cdot 70\right\rangle \\
& \left\langle\mathrm{PuO}_{2}\right\rangle+0.35(\mathrm{CO})=\left\langle\mathrm{PuO}_{1} \cdot 65\right\rangle \\
& \left\langle\mathrm{PuO}_{2}\right\rangle+0.39(\mathrm{CO})=\left\langle\mathrm{PuO}_{1} \cdot 61\right\rangle \\
& \left\langle\mathrm{PuO}_{2}\right\rangle+0.50(\mathrm{CO})=\left\langle\mathrm{PuO}_{1} \cdot 50^{\rangle}\right\rangle
\end{aligned}
$$

$\Delta \mathbf{G}$

kcal/mole

$$
\begin{aligned}
& +0.02 \\
& +0.05 \\
& +0.08 \\
& +0.10 \\
& +0.15 \\
& +0.20 \\
& +0.25 \\
& +0.30 \\
& +0.35 \\
& +0.39 \\
& +0.50
\end{aligned}
$$

$\left(\mathrm{CO}_{2}\right)$

$\left(\mathrm{CO}_{2}\right)$

$\left(\mathrm{CO}_{2}\right)$

$\left(\mathrm{CO}_{2}\right)$

$\left(\mathrm{CO}_{2}\right)$

$\left(\mathrm{CO}_{2}\right)$

$\left(\mathrm{CO}_{2}\right)$

$\left(\mathrm{CO}_{2}\right)$

$\left(\mathrm{CO}_{2}\right)$

$\left(\mathrm{CO}_{2}\right)$

(¿0,

$+\quad 0.21$
$+\quad 0.69$
$+\quad 1.26$
$+\quad 1.71$
$+\quad 2.94$
$+\quad 4.33$
$+\quad 5.89$
$+\quad 7.62$
$+\quad 9.39$
$+\quad 10.89$
$+\quad 14.96$

$+0.21$ 69 94

89

4.96

\section{TABLE B - 26}

REACTIONS BETWEEN $<\mathrm{PuO}_{2}>$ and $(\mathrm{CO})$ at $1500^{\circ} \mathrm{K}$

Reaction

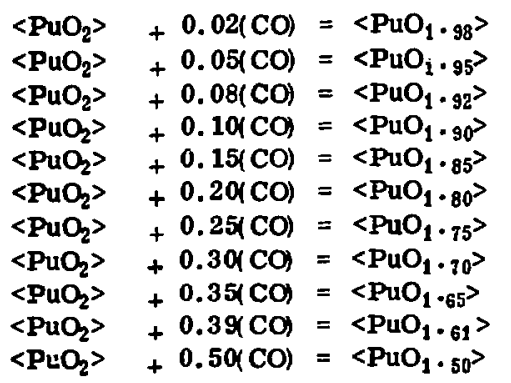
$+0.02$ $+0.05$ $+0.08$ $+0.10$ $+0.15$ $+0.20$ $+0.25$ $+0.30$ $+0.35$ $+0.39$ $+0.50$
$\Delta^{G}$

kcal/mole

$\begin{array}{llr}\left(\mathrm{CO}_{2}\right) & + & 0.12 \\ \left(\mathrm{CO}_{2}\right) & + & 0.53 \\ \left(\mathrm{CO}_{2}\right) & + & 1.03 \\ \left(\mathrm{CO}_{2}\right) & + & 1.15 \\ \left(\mathrm{CO}_{2}\right) & + & 2.33 \\ \left(\mathrm{CO}_{2}\right) & + & 4.30 \\ \left(\mathrm{CO}_{2}\right) & + & 5.58 \\ \left(\mathrm{CO}_{2}\right) & + & 7.35 \\ \left(\mathrm{CO}_{2}\right) & + & 9.18 \\ \left(\mathrm{CO}_{2}\right) & + & 10.72 \\ \left(\mathrm{CO}_{2}\right) & + & 14.90\end{array}$


REACTIONS BETWEEN $<\mathrm{PuO}_{2}>$ and $(\mathrm{CO})$ at $1600^{\circ} \mathrm{K}$

\section{Reaction}

\begin{tabular}{|c|c|c|}
\hline$<\mathrm{PuO}_{2}>$ & $+0.02(\mathrm{CO})$ & $=\left\langle\mathrm{PuO}_{1} \cdot 98\right\rangle$ \\
\hline$<\mathrm{PuO}_{2}>$ & $+0.05(\mathrm{CO})$ & $=\left\langle\mathrm{PuO}_{1} \cdot 95\right\rangle$ \\
\hline$<\mathrm{PuO}_{2}>$ & $+0.08(\mathrm{CO})$ & $=\left\langle\mathrm{PuO}_{1} \cdot \mathrm{g2}\right\rangle$ \\
\hline$<\mathrm{PuO}_{2}>$ & $+0.10(\mathrm{CO})$ & $=\left\langle\mathrm{PuO}_{1} \cdot 90^{\prime}\right\rangle$ \\
\hline & $+0.15(\mathrm{CO})$ & $=\left\langle\mathrm{PuO}_{1} \cdot 85\right\rangle$ \\
\hline$\left.<\mathrm{PuO}_{2}\right\rangle$ & $+0.20(\mathrm{CO})$ & $=\left\langle\mathrm{PuO}_{1 \cdot 80^{\prime}}\right\rangle$ \\
\hline$\left\langle\mathrm{PuO}_{2}\right\rangle$ & $+0.25(\mathrm{CO})$ & $=\left\langle\mathrm{PuO}_{1} \cdot 75^{\rangle}\right\rangle$ \\
\hline$\left\langle\mathrm{PuO}_{2}\right\rangle$ & $+0.30(\mathrm{CO})$ & $=\left\langle\mathrm{PuO}_{1} \cdot 70^{\rangle}\right.$ \\
\hline $\mathrm{PuO}_{2}>$ & $+0.35(\mathrm{CO})$ & $=\left\langle\mathrm{PuO}_{1} \cdot 65\right\rangle$ \\
\hline$\left\langle\mathrm{PuO}_{2}\right\rangle$ & $+0.39 \mathrm{CO})$ & $=\left\langle\mathrm{PuO}_{1} \cdot \mathrm{G1}_{1}\right\rangle$ \\
\hline$\left\langle\mathrm{PuO}_{2}\right\rangle$ & $+0.50(\mathrm{CO})$ & $=\left\langle\mathrm{PuO}_{1} \cdot 50^{\rangle}\right.$ \\
\hline
\end{tabular}

$\Delta \mathrm{G}$

kcal/mole

+0.02
+0.05
+0.08
+0.10
+0.15
+0.20
+0.25
$+\mathbf{0 . 3 0}$
$+\mathbf{0 . 3 5}$
$+\mathbf{0 . 3 9}$
$+\mathbf{0 . 5 0}$

$\left(\mathrm{CO}_{2}\right)$

$\left(\mathrm{CO}_{2}\right)$

$\left(\mathrm{CO}_{2}\right)$

$\left(\mathrm{CO}_{2}\right)$

$\left(\mathrm{CO}_{2}\right)$

$\left(\mathrm{CO}_{2}\right)$

$\left(\mathrm{CO}_{2}\right)$

$\left(\mathrm{CO}_{2}\right)$

$\left(\mathrm{CO}_{2}\right)$

$\left(\mathrm{CO}_{2}\right)$

$\left(\mathrm{CO}_{2}\right)$
0.03

0.36

0.80

1.19

2.31

3.67

5.26

$+7.08$

$+8.96$

$+\quad 10.54$

$+14.85$

TABLE B -28

REACTIONS BETWEEN $<\mathrm{PuO}_{2}>$ and $(\mathrm{CO})$ at $1700^{\circ} \mathrm{K}$

Reaction

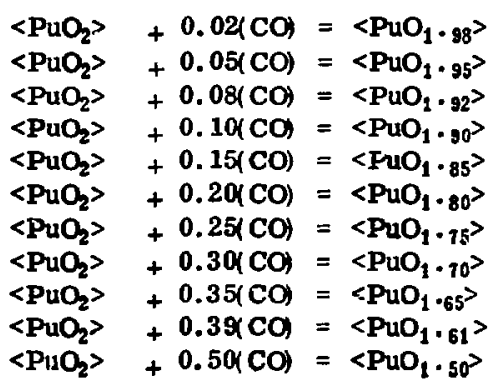

$A^{G}$

kcal/mole

$$
\begin{array}{r}
+0.02 \\
+0.05 \\
+0.08 \\
+0.10 \\
+0.15 \\
+0.20 \\
+0.25 \\
+0.30 \\
+0.35 \\
+0.39 \\
+0.50
\end{array}
$$


Reaction

\begin{tabular}{|c|c|c|c|c|c|c|}
\hline$\left\langle\mathrm{PuO}_{2}\right\rangle$ & $+0.02(\mathrm{CO})$ & $=\left\langle\mathrm{PuO}_{1} \cdot \mathrm{sg}\right\rangle$ & +0.02 & $\left(\mathrm{CO}_{2}\right)$ & - & 0.15 \\
\hline$\left\langle\mathrm{PuQ}_{2}\right\rangle$ & $+0.05(\mathrm{CO})$ & $=\left\langle\mathrm{PuO}_{1} \cdot 95\right\rangle$ & +0.05 & $\left(\mathrm{CO}_{2}\right)$ & + & 0.02 \\
\hline$\left\langle\mathrm{PuO}_{2}\right\rangle$ & $+0.08(\mathrm{CO})$ & $=\left\langle\mathrm{PuO} \mathrm{O}_{1} \cdot \mathrm{g2}\right\rangle$ & +0.08 & $\left(\mathrm{CO}_{2}\right)$ & + & 0.35 \\
\hline$\left\langle\mathrm{PuO}_{2}\right\rangle$ & $+0.10(\mathrm{CO})$ & $=\left\langle\mathrm{PuO}_{1} \cdot 90\right\rangle$ & +0.10 & $\left(\mathrm{CO}_{2}\right)$ & + & 0.68 \\
\hline$\left\langle\mathrm{PuO}_{2}\right\rangle$ & $+0.15(\mathrm{CO})$ & $=\left\langle\mathrm{PuO}_{1} \cdot 85\right\rangle$ & +0.15 & $\left(\mathrm{CO}_{2}\right)$ & + & 1.68 \\
\hline$\left\langle\mathrm{PuO}_{2}\right\rangle$ & $+0.20(\mathrm{CO})$ & $=\left\langle\mathrm{PuO}_{1} \cdot \mathrm{BO}\right\rangle$ & $+0,20$ & $\left(\mathrm{CO}_{2}\right)$ & + & 3.00 \\
\hline$\left\langle\mathrm{PuO}_{2}\right\rangle$ & $+0.25(\mathrm{CO})$ & $=\left\langle\mathrm{PuO}_{1} \cdot 15\right\rangle$ & +0.25 & $\left(\mathrm{CO}_{2}\right)$ & + & 4.64 \\
\hline$\left\langle\mathrm{PuO}_{2}\right\rangle$ & $+0.30(\mathrm{CO})$ & $=\left\langle\mathrm{PuO}_{1} \cdot 90^{\prime}\right\rangle$ & +0.30 & $\left(\mathrm{CO}_{2}\right)$ & + & 6.54 \\
\hline$\left\langle\mathrm{PuO}_{2}\right\rangle$ & $+0.35(\mathrm{CO})$ & $=\left\langle\mathrm{PuO}_{1 \cdot 65}\right\rangle$ & +0.35 & $\left(\mathrm{CO}_{2}\right)$ & + & 8.52 \\
\hline$\left\langle\mathrm{PuO}_{2}\right\rangle$ & $+0.39(\mathrm{CO})$ & $=\left\langle\mathrm{PuO}_{1} \cdot 61\right\rangle$ & +0.39 & $\left(\mathrm{CO}_{2}\right)$ & + & 10.18 \\
\hline$\left\langle\mathrm{PuO}_{2}\right\rangle$ & $+0.50(\mathrm{CO})$ & $=\left\langle\mathrm{PuO}_{1} \cdot 50^{\prime}\right\rangle$ & +0.50 & $\left(\mathrm{CO}_{2}\right)$ & + & 14.74 \\
\hline
\end{tabular}

$\Delta \mathbf{G}$

kcal/mole

0.15

0.02

68

64

6.54

10.18

14.74

TABLE B $-\mathbf{3 0}$

REACTIONS BETWEEN $<\mathrm{PuO}_{2}>$ and $(\mathrm{CO})$ at $1900^{\circ} \mathrm{K}$

Reaction

$$
\begin{aligned}
& \left\langle\mathrm{PuO}_{2}\right\rangle+0.02(\mathrm{CO})=\left\langle\mathrm{PuO}_{1} \cdot{ }_{98}\right\rangle \\
& \left\langle\mathrm{PuO}_{2}\right\rangle+0.05(\mathrm{CO})=\left\langle\mathrm{PuO}_{1} \cdot 95\right\rangle \\
& \left.\left\langle\mathrm{PuO}_{2}\right\rangle+0.081 \mathrm{CO}\right\rangle=\left\langle\mathrm{PuO}_{1} \cdot 92\right\rangle \\
& \left\langle\mathrm{PuO}_{2}\right\rangle+0.10(\mathrm{CO})=\left\langle\mathrm{PuO}_{1} \cdot 30^{3}\right\rangle \\
& \left\langle\mathrm{PuO}_{2}\right\rangle+0.15(\mathrm{CO})=\left\langle\mathrm{PuO}_{1} \cdot 85\right\rangle \\
& \left\langle\mathrm{PuO}_{2}\right\rangle+0.20(\mathrm{CO})=\left\langle\mathrm{PuO}_{1} \cdot 80\right\rangle \\
& \left\langle\mathrm{PuO}_{2}\right\rangle+0.25(\mathrm{CO})=\left\langle\mathrm{PuO}_{1} \cdot 15\right\rangle \\
& \left\langle\mathrm{PuO}_{2}\right\rangle+0.30(\mathrm{CO})=\left\langle\mathrm{PuO}_{1} \cdot 70^{2}\right\rangle \\
& \left\langle\mathrm{PuO}_{2}\right\rangle+0.35(\mathrm{CO})=\left\langle\mathrm{PuO}_{1.65}\right\rangle \\
& \begin{array}{l}
\left\langle\mathrm{PuO}_{2}\right\rangle+0.39\left(\mathrm{CO}=\left\langle\mathrm{PuO}_{1} \cdot 61\right\rangle\right. \\
\left.\left\langle\mathrm{PuO}_{2}\right\rangle+0.5 \alpha \mathrm{CO}\right\rangle=\left\langle\mathrm{PuO}_{1} \cdot 50^{\rangle}\right.
\end{array}
\end{aligned}
$$

$\Delta \mathrm{C}$

$\mathrm{kcal} / \mathrm{mole}$

$\begin{array}{llll}+0.02 & \left(\mathrm{CO}_{2}\right) & - & 0.24 \\ +0.05 & \left(\mathrm{CO}_{2}\right) & - & 0.15 \\ +0.08 & \left(\mathrm{CO}_{2}\right) & + & 0.12 \\ +0.10 & \left(\mathrm{CO}_{2}\right) & + & 0.42 \\ +0.15 & \left(\mathrm{CO}_{2}\right) & + & 1.36 \\ +0.20 & \left(\mathrm{CO}_{2}\right) & + & 2.66 \\ +0.25 & \left(\mathrm{CO}_{2}\right) & + & 4.32 \\ +0.30 & \left(\mathrm{CO}_{2}\right) & + & 6.26 \\ +0.35 & \left(\mathrm{CO}_{2}\right) & + & 8.29 \\ +0.39 & \left(\mathrm{CO}_{2}\right) & + & 9.99 \\ +0.50 & \left(\mathrm{CO}_{2}\right) & + & 14.67\end{array}$




\section{Reaction}

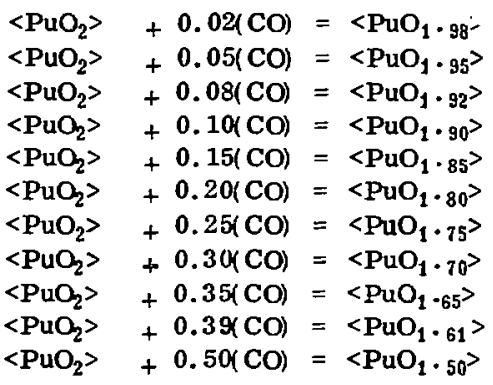

$\Delta^{\mathrm{G}}$

kcal/mole

+0.02
+0.05
+0.08
+0.10
+0.15
+0.20
+0.25
+0.30
+0.35
+0.39
+0.50

$\left(\mathrm{CO}_{2}\right)$

0.33

$\left(\mathrm{CO}_{2}\right)$

$\left(\mathrm{CO}_{2}\right)$

$\left(\mathrm{CO}_{2}\right)$

$\left(\mathrm{CO}_{2}\right)$

$\left(\mathrm{CO}_{2}\right)$

$\left(\mathrm{CO}_{2}\right)$

$\left(\mathrm{CO}_{2}\right)$

$\left(\mathrm{CO}_{2}\right)$

$\left(\mathrm{CO}_{2}\right)$

$\left(\mathrm{CO}_{2}\right)$ $-\quad 0.32$

- 0.11

$+\quad 0.16$

$+\quad 1.04$

$+2.32$

$+\quad 4.00$

$+\quad 5.98$

$+8.06$

$+9.80$

$+14.60$

TABLE B -32

REACTIONS BETWEEN $<\mathrm{PuO}_{2}>$ and $(\mathrm{CO})$ at $2100^{\circ} \mathrm{K}$

\section{Reaction}

$+0.02$

$+0.05$

$+0.08$

$+0.10$

$+0.15$

$+0,20$

$+0.25$

$+0.30$

$+0.35$

$+0.39$

$+0.50$
$\Delta \mathbf{G}$

$\mathrm{kcal} / \mathrm{mole}$

$\left(\mathrm{CO}_{2}\right)$

$\left(\mathrm{CO}_{2}\right)$

$\left(\mathrm{CO}_{2}\right)$

$\left(\mathrm{CO}_{2}\right)$

$\left(\mathrm{CO}_{2}\right)$

$\left(\mathrm{CO}_{2}\right)$

$\left(\mathrm{CO}_{2}\right)$

$\left(\mathrm{CO}_{2}\right)$

$\left(\mathrm{CO}_{2}\right)$

$\left(\mathrm{CO}_{2}\right)$

$\left(\mathrm{CO}_{2}\right)$
0.42

- 0.49

- 0.34

- 0.10

0.72
$+\quad 0.98$

$+\quad 0.72$
$+\quad 1.98$

$+\quad 3.68$
$+\quad 5.70$

$+\quad 5.70$
$+\quad 7.83$

$+7.83$

+
$+\quad 9.61$

$+\quad 14.53$ 
REACTIONS BETWEEN $<\mathrm{PuO}_{2}>$ and (CO) at $2200^{\circ} \mathrm{K}$

Reaction

\begin{tabular}{|c|c|c|c|c|c|c|}
\hline$\left\langle\mathrm{PuO}_{2}\right\rangle$ & $+0.02(\mathrm{CO})$ & $=\left\langle\mathrm{PuO}_{1} \cdot{ }_{88}\right\rangle$ & +0.02 & $\left(\mathrm{CO}_{2}\right)$ & - & 0.51 \\
\hline$\left\langle\mathrm{PuO}_{2}\right\rangle$ & $+0.05(\mathrm{CO})$ & $=\left\langle\mathrm{PuO}_{1} \cdot 95\right\rangle$ & +0.05 & $\left(\mathrm{CO}_{2}\right)$ & - & 0.66 \\
\hline$\left\langle\mathrm{PuO}_{2}\right\rangle$ & $+0.08(\mathrm{CO})$ & $=\left\langle\mathrm{PuO}_{3} \cdot 92\right\rangle$ & +0.08 & $\left(\mathrm{CO}_{2}\right)$ & - & 0.57 \\
\hline$\left\langle\mathrm{PuO}_{2}\right\rangle$ & $+0.10(\mathrm{CO})$ & $=\left\langle\mathrm{PuO}_{1} \cdot 90^{\prime}\right\rangle$ & +0.10 & $\left(\mathrm{CO}_{2}\right)$ & - & 0.36 \\
\hline$\left\langle\mathrm{PuO}_{2}\right\rangle$ & $+0.15(\mathrm{CO})$ & $=\left\langle\mathrm{PuO}_{1} \cdot 85\right\rangle$ & +0.15 & $\left(\mathrm{CO}_{2}\right)$ & $t$ & 0.40 \\
\hline$\left.<\mathrm{PuO}_{2}\right\rangle$ & $+0.20(\mathrm{CO})$ & $=\left\langle\mathrm{PuO}_{1} \cdot 80^{2}\right\rangle$ & +0.20 & $\left(\mathrm{CO}_{2}\right)$ & + & 1.64 \\
\hline$<\mathrm{PuO}_{2}>$ & $+0.25(\mathrm{CO})$ & $=\left\langle\mathrm{PuO}_{1} \cdot 75^{\prime}\right\rangle$ & +0.25 & $\left(\mathrm{CO}_{2}\right)$ & + & 3.36 \\
\hline$\left\langle\mathrm{PuO}_{2}\right\rangle$ & $+0.30(\mathrm{CO})$ & $=\left\langle\mathrm{PuO}_{1} \cdot 70\right\rangle$ & +0.30 & $\left(\mathrm{CO}_{2}\right)$ & + & 5.42 \\
\hline$\left\langle\mathrm{PuO}_{2}\right\rangle$ & $+0.35(\mathrm{CO})$ & $=\left\langle\mathrm{PuO}_{1 \cdot 65}\right\rangle$ & +0.35 & $\left(\mathrm{CO}_{2}\right)$ & + & 7.60 \\
\hline$<\mathrm{PuO}_{2}>$ & $+0.39(\mathrm{CO})$ & $=\left\langle\mathrm{PuO}_{1 \cdot 61}\right\rangle$ & +0.39 & $\left(\mathrm{CO}_{2}\right)$ & + & 9.42 \\
\hline$\left\langle\mathrm{PuO}_{2}\right\rangle$ & $+0.50(\mathrm{CO})$ & $=\left\langle\mathrm{PuO}_{1} \cdot 50^{\prime}\right\rangle$ & +0.50 & $\left(\mathrm{CO}_{2}\right)$ & + & 14.46 \\
\hline
\end{tabular}

$\Delta \mathbf{G}$

kcal/mole

TABLE B -34

REACTIONS BETWEEN $<\mathrm{PuO}_{2}>$ and ( $\mathrm{CO}$ ) at $2300^{\circ} \mathrm{K}$

Reaction

\begin{tabular}{|c|c|c|}
\hline$\left\langle\mathrm{PuO}_{2}\right\rangle$ & $+0.02(\mathrm{CO})$ & $=\left\langle\mathrm{PuO}_{1} \cdot 98^{\prime}\right\rangle$ \\
\hline$\left\langle\mathrm{PuO}_{2}\right\rangle$ & $+0.05(\mathrm{CO})$ & $=\left\langle\mathrm{PuO}_{1} \cdot 95^{\prime}\right\rangle$ \\
\hline$\left\langle\mathrm{PuO}_{2}\right\rangle$ & $+0.08(\mathrm{CO})$ & $=\left\langle\mathrm{PuO}_{1} \cdot \mathrm{9P}_{2}\right\rangle$ \\
\hline$\left\langle\mathrm{PuO}_{2}\right\rangle$ & $+0.10(\mathrm{CO})$ & $=\left\langle\mathrm{PuO}_{1} \cdot 90^{\prime}\right\rangle$ \\
\hline$\left\langle\mathrm{PuO}_{2}\right\rangle$ & $+0.15(\mathrm{CO})$ & $=\left\langle\mathrm{PuO}_{1} \cdot \mathrm{B5}\right\rangle$ \\
\hline$\left\langle\mathrm{PuO}_{2}\right\rangle$ & $+0.20(\mathrm{CO})$ & $=\left\langle\mathrm{PuO}_{1} \cdot 80^{\prime}\right\rangle$ \\
\hline$\left\langle\mathrm{PuO}_{2}\right\rangle$ & $+0.25(\mathrm{CO})$ & $=\left\langle\mathrm{PuO}_{1} \cdot 75\right\rangle$ \\
\hline$\left\langle\mathrm{PuO}_{2}\right\rangle$ & $+0.30(\mathrm{CO})$ & $=\left\langle\mathrm{PuO}_{1} \cdot 70\right\rangle$ \\
\hline$\left\langle\mathrm{PuO}_{2}\right\rangle$ & $+0.35(\mathrm{CO})$ & $=\left\langle\mathrm{PuO}_{1} \cdot 65\right\rangle$ \\
\hline & $+0.39(\mathrm{CO})$ & $=\left\langle\mathrm{PuO}_{1} \cdot{ }_{61}\right\rangle$ \\
\hline$\left.<\mathrm{PuO}_{2}\right\rangle$ & $+0.50(\mathrm{CO})$ & $=\left\langle\mathrm{PuO}_{1} \cdot 50^{\rangle}\right.$ \\
\hline
\end{tabular}

$\Delta \mathrm{G}$

kcal/mole

+0.02
+0.05
+0.08
+0.10
+0.15
+0.20
+0.25
+0.30
+0.35
+0.39
+0.50

$+0.02$

( $\left.\mathrm{CO}_{2}\right)$

$\left(\mathrm{CO}_{2}\right)$

$\left(\mathrm{CO}_{2}\right)$

$\left(\mathrm{CO}_{2}\right)$

$\left(\mathrm{CO}_{2}\right)$

$\left(\mathrm{CO}_{2}\right)$

$\left(\mathrm{CO}_{2}\right)$

$\left(\mathrm{CO}_{2}\right)$

$\left(\mathrm{CO}_{2}\right)$

$\left(\mathrm{CO}_{2}\right)$

$\left(\mathrm{CO}_{2}\right)$ 
REACTIONS BETWEEN $<\mathrm{PuO}_{2}>$ and $\left(\mathrm{H}_{2}\right)$ at $298{ }^{\circ} \mathrm{K}$

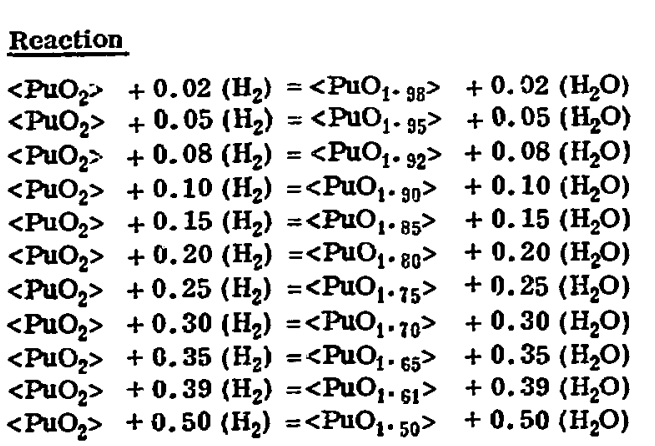

$\Delta G$ $\mathrm{kcal} / \mathrm{mole}$

$+18.69$

TABLE B-36

REACTIONS BETWEEN $<\mathrm{PuO}_{2}>$ and $\left(\mathrm{H}_{2}\right)$ at $500{ }^{\circ} \mathrm{K}$

\section{Reaction}

$\left.\left\langle\mathrm{PuO}_{2}\right\rangle+0.02 ; \mathrm{I}_{2}\right)=\left\langle\mathrm{PuO}_{1 \cdot 98}\right\rangle+0.02\left(\mathrm{H}_{2} \mathrm{O}\right)$ $\left\langle\mathrm{PuO}_{2}\right\rangle+0.05\left(\mathrm{H}_{2}\right)=\left\langle\mathrm{PuO}_{1 \cdot 95}\right\rangle+0.05\left(\mathrm{H}_{2} \mathrm{O}\right)$ $\left\langle\mathrm{PuO}_{2}\right\rangle+0.08\left(\mathrm{H}_{2}\right)=\left\langle\mathrm{PuO}_{1} \cdot 92\right\rangle+0.08\left(\mathrm{H}_{2} \mathrm{O}\right)$ $\left\langle\mathrm{PuO}_{2}\right\rangle+0.10\left(\mathrm{H}_{2}\right)=\left\langle\mathrm{PuO}_{1 \cdot 90}\right\rangle+0.10\left(\mathrm{H}_{2} \mathrm{O}\right)$ $\left\langle\mathrm{PuO}_{2}\right\rangle+0.15\left(\mathrm{H}_{2}\right)=\left\langle\mathrm{PnO}_{1 \cdot 85}\right\rangle+0.15\left(\mathrm{H}_{2} \mathrm{O}\right\rangle$ $\left\langle\mathrm{PuO}_{2}\right\rangle+0.20\left(\mathrm{H}_{2}\right)=\left\langle\mathrm{PuO}_{1 \cdot 80}\right\rangle+0.20\left(\mathrm{H}_{2} \mathrm{O}\right)$ $\left\langle\mathrm{PuO}_{2}\right\rangle+0.25\left(\mathrm{H}_{2}\right)=\left\langle\mathrm{PuO}_{1} \cdot .5\right\rangle+0.25\left(\mathrm{H}_{2} \mathrm{O}\right)$ $\left\langle\mathrm{PuO}_{2}\right\rangle+0.30\left(\mathrm{H}_{2}\right)=\left\langle\mathrm{PuO}_{1} \cdot 70\right\rangle+0.30\left(\mathrm{H}_{2} \mathrm{O}\right)$ $\left\langle\mathrm{PuO}_{2}\right\rangle+0.35\left(\mathrm{H}_{2}\right)=\left\langle\mathrm{PuO}_{1} \cdot 65\right\rangle+0.35\left(\mathrm{H}_{2} \mathrm{O}\right)$ $\left\langle\mathrm{PuO}_{2}\right\rangle+0.39\left(\mathrm{H}_{2}\right)=\left\langle\mathrm{PuO}_{1 \cdot 61}\right\rangle+0.39\left(\mathrm{H}_{2} \mathrm{O}\right)$ $\left\langle\mathrm{PuO}_{2}\right\rangle+0.50\left(\mathrm{H}_{2}\right)=\left\langle\mathrm{PuO}_{1} \cdot 50\right\rangle+0.50\left(\mathrm{H}_{2} \mathrm{O}\right)$
$\Delta \mathbf{G}$ kcal/mole

$+1.10$

$+2.43$

$+3.66$

$+4.46$

$+6.45$

$+8.23$

$+9.81$

$+11.39$

$+12.92$

$+14.23$

$+17.67$ 
REACTIONS BETWEEN $<\mathrm{PuO}_{2}>$ and $\left(\mathrm{H}_{2}\right)$ at $800{ }^{\circ} \mathrm{K}$

\section{Reaction}

$$
\begin{aligned}
& \left\langle\mathrm{PuO}_{2}\right\rangle+0.02\left(\mathrm{H}_{2}\right)=\left\langle\mathrm{PuO}_{1} \cdot 9 \mathrm{~g}\right\rangle+0.02\left(\mathrm{H}_{2} \mathrm{O}\right) \\
& \left\langle\mathrm{PuO}_{2}\right\rangle+0.05\left(\mathrm{H}_{2}\right)=\left\langle\mathrm{PuO}_{1} \cdot 95+0.05\left(\mathrm{H}_{2} \mathrm{O}\right)\right. \\
& \left\langle\mathrm{PuO}_{2}\right\rangle+0.08\left(\mathrm{H}_{2}\right)=\left\langle\mathrm{PuO}_{1} \cdot 92\right\rangle+0.08\left(\mathrm{H}_{2} \mathrm{O}\right) \\
& \left\langle\mathrm{PuO}_{2}\right\rangle+0.10\left(\mathrm{H}_{2}\right)=\left\langle\mathrm{PuO}_{1} \cdot 90\right\rangle+0.10\left(\mathrm{H}_{2} \mathrm{O}\right) \\
& \left\langle\mathrm{PuO}_{2}\right\rangle+0.15\left(\mathrm{H}_{2}\right)=\left\langle\mathrm{PuO}_{1} \cdot 85\right\rangle+0.15\left(\mathrm{H}_{2} \mathrm{O}\right) \\
& \left\langle\mathrm{PuO}_{2}\right\rangle+0.20\left(\mathrm{H}_{2}\right)=\left\langle\mathrm{PuO}_{1 \cdot 60}\right\rangle+0.20\left(\mathrm{H}_{2} \mathrm{O}\right\rangle \\
& \left\langle\mathrm{PuO}_{2}\right\rangle+0.25\left(\mathrm{H}_{2}\right)=\left\langle\mathrm{PuO}_{1 \cdot 75}\right\rangle+0.25\left(\mathrm{H}_{2} \mathrm{O}\right) \\
& \left\langle\mathrm{PuO}_{2}\right\rangle+0.30\left(\mathrm{H}_{2}\right)=\left\langle\mathrm{PuO}_{1 \cdot 70}\right\rangle+0.30\left(\mathrm{H}_{2} \mathrm{O}\right) \\
& \left\langle\mathrm{PuO}_{2}\right\rangle+0.35\left(\mathrm{H}_{2}\right)=\left\langle\mathrm{PuO}_{1 \cdot 65}\right\rangle+0.35\left(\mathrm{H}_{2} \mathrm{O}\right) \\
& \left\langle\mathrm{PuO}_{2}\right\rangle+0.39\left(\mathrm{H}_{2}\right)=\left\langle\mathrm{PuO}_{1 \cdot 61}\right\rangle+0.39\left(\mathrm{H}_{2} \mathrm{O}\right) \\
& \left\langle\mathrm{PuO}_{2}\right\rangle+0.50\left(\mathrm{H}_{2}\right\rangle=\left\langle\mathrm{PuO}_{1} \cdot 50+0.50\left(\mathrm{H}_{2} \mathrm{O}\right\rangle\right.
\end{aligned}
$$

\begin{tabular}{|c|c|c|c|}
\hline \multicolumn{3}{|c|}{ Reaction } & $\mathrm{kcal} / \mathrm{mole}$ \\
\hline $\begin{array}{l}\left\langle\mathrm{PuO}_{2}\right\rangle \\
\left\langle\mathrm{PuO}_{2}\right\rangle\end{array}$ & $\begin{aligned}+0.02\left(\mathrm{H}_{2}\right) & =\left\langle\mathrm{PuO}_{1} \cdot \text { 98 }\right\rangle \\
+0.05\left(\mathrm{H}_{2}\right) & =\left\langle\mathrm{PuO}_{1.95}\right\rangle\end{aligned}$ & $\begin{array}{l}+0.02\left(\mathrm{H}_{2} \mathrm{O}\right) \\
+0.05\left(\mathrm{H}_{2} \mathrm{O}\right)\end{array}$ & $\begin{array}{l}+0.58 \\
+\quad 1.40\end{array}$ \\
\hline$<\mathrm{PuO}_{2}>$ & $+0.08\left(\mathrm{H}_{2}\right)=\left\langle\mathrm{PuO}_{1 \cdot 92}\right\rangle$ & $+0.08\left(\mathrm{H}_{2} \mathrm{O}\right)$ & +2.22 \\
\hline$\left.<\mathrm{PuO}_{2}\right\rangle$ & $+0.10\left(\mathrm{H}_{2}\right)=\left\langle\mathrm{PuO}_{1 \cdot 90}\right\rangle$ & $+0.10\left(\mathrm{H}_{2} \mathrm{O}\right)$ & +2.80 \\
\hline$\left\langle\mathrm{PuO}_{2}\right\rangle$ & $+0.15\left(\mathrm{H}_{2}\right)=\left\langle\mathrm{PuO}_{1 \cdot 85}\right\rangle$ & $+0.15\left(\mathrm{H}_{2} \mathrm{O}\right)$ & +4.29 \\
\hline$\left\langle\mathrm{PuO}_{2}\right\rangle$ & $+0.20\left(\mathrm{H}_{2}\right)=\left\langle\mathrm{PuO}_{1 \cdot 80}\right\rangle$ & $+0.20\left(\mathrm{H}_{2} \mathrm{O}\right)$ & +5.79 \\
\hline$\left\langle\mathrm{PuO}_{2}\right\rangle$ & $+J .25\left(\mathrm{H}_{2}\right)=\left\langle\mathrm{PuO}_{1 \cdot 75}\right\rangle$ & $+0.25\left(\mathrm{H}_{2} \mathrm{O}\right)$ & +7.29 \\
\hline$\left\langle\mathrm{PuO}_{2}\right\rangle$ & $+0.30\left(\mathrm{H}_{2}\right)=\left\langle\mathrm{PuO}_{1 \cdot 70}\right\rangle$ & $+0.30\left(\mathrm{H}_{2} \mathrm{O}\right)$ & +8.89 \\
\hline$\left\langle\mathrm{TuO}_{2}\right\rangle$ & $+0.35\left(\mathrm{H}_{2}\right)=\left\langle\mathrm{PuO}_{1 \cdot 65}\right\rangle$ & $+0.35\left(\mathrm{H}_{2} \mathrm{O}\right)$ & +10.49 \\
\hline$\left\langle\mathrm{PuO}_{2}\right\rangle$ & $+0.39\left(\mathrm{H}_{2}\right)=\left\langle\mathrm{PuO}_{1 \cdot 61}\right\rangle$ & $+0.39\left(\mathrm{H}_{2} \mathrm{O}\right)$ & +11.84 \\
\hline$\left\langle\mathrm{PuO}_{2}\right\rangle$ & $+0.50\left(\mathrm{H}_{2}\right)=\left\langle\mathrm{PuO}_{1 \cdot 50}\right\rangle$ & $+0.50\left(\mathrm{H}_{2} \mathrm{O}\right)$ & +15.48 \\
\hline
\end{tabular}

$\Delta \mathrm{G}$

$\mathrm{kcal} / \mathrm{mole}$

$+\quad 0.79$
$+\quad 1.81$
$+\quad 2.79$
$+\quad 3.46$
$+\quad 5.14$
$+\quad 6.75$
$+\quad 8.28$
$+\quad 9.87$
+11.43
+12.77
+16.32

REACTIONS BETWEEN $<\mathrm{PuO}_{2}>$ and $\left(\mathrm{H}_{2}\right)$ at $1000^{\circ} \mathrm{K}$ 
TABLE B- 39

REACTIONS BETWEEN $<\mathrm{PuO}_{2}>$ and $\left(\mathrm{H}_{2}\right)$ at $1100^{\circ} \mathrm{K}$

\begin{tabular}{|c|c|c|c|c|}
\hline \multicolumn{4}{|c|}{ Reaction } & $\begin{array}{c}\Delta G \\
\mathrm{kcal} / \mathrm{mol} \\
\end{array}$ \\
\hline & $+0.02\left(\mathrm{H}_{2}\right)$ & $=\left\langle\mathrm{PuO}_{1} \cdot 98\right\rangle$ & $+0.02\left(\mathrm{H}_{2} \mathrm{O}\right)$ & +0.48 \\
\hline & & $=\left\langle\mathrm{PuO}_{1 \cdot 9 \bar{j}}\right\rangle$ & $+0.05\left(\mathrm{H}_{2} \mathrm{O}\right)$ & +1.19 \\
\hline & $+0.08\left(\mathrm{H}_{2}\right)$ & $=\left\langle\mathrm{PuO}_{\left.1 \cdot \mathrm{g}_{2}\right\rangle}\right\rangle$ & $+0.09\left(\mathrm{H}_{2} \mathrm{O}\right)$ & +1.93 \\
\hline $\mathrm{PuO}_{2} \mathrm{P}$ & $\div 0.10\left(\mathrm{H}_{2}\right)$ & $=\left\langle\mathrm{PuO}_{1} \cdot \mathbf{9 0}\right\rangle$ & $+0.10\left(\mathrm{H}_{2} \mathrm{O}\right)$ & +2.47 \\
\hline $2>$ & $+0.15\left(\mathrm{H}_{2}\right)$ & $=\left\langle\mathrm{PuO}_{1 \cdot 85}\right\rangle$ & $+0.15\left(\mathrm{H}_{2} \mathrm{O}\right)$ & +3.87 \\
\hline $\mathrm{PuO}_{2}>$ & $+0.20\left(\mathrm{H}_{2}\right)$ & $=\left\langle\mathrm{PuO}_{1 \cdot 80}\right\rangle$ & $+0.20\left(\mathrm{H}_{2} \mathrm{O}\right)$ & +5.32 \\
\hline $\mathrm{PuO}>$ & $+0.25\left(\mathrm{H}_{2}\right)$ & $=\left\langle\mathrm{PuO}_{1 \cdot 75}\right\rangle$ & $+0.25\left(\mathrm{H}_{2} \mathrm{O}\right)$ & +6.80 \\
\hline $\mathrm{uO}_{2}>$ & $+0.30\left(\mathrm{H}_{2}\right)$ & $=\left\langle\mathrm{PuO}_{1 \cdot 70}\right\rangle$ & $+0.30\left(\mathrm{H}_{2} \mathrm{O}\right)$ & +8.41 \\
\hline & $+0.35\left(\mathrm{H}_{2}\right)$ & $=\left\langle\mathrm{PuO}_{1 \cdot 65}\right\rangle$ & $+0.35\left(\mathrm{H}_{2} \mathrm{O}\right)$ & +10.02 \\
\hline $\mathrm{PuO}_{2}>$ & $+0.39\left(\mathrm{H}_{2}\right)$ & $=\left\langle\mathrm{PuO}_{1} \cdot G 1\right\rangle$ & $+0.39\left(\mathrm{H}_{2} \mathrm{O}\right)$ & +11.39 \\
\hline $\mathrm{PuO}_{2}>$ & $+0.50\left(\mathrm{H}_{2}\right)$ & $=\left\langle\mathrm{PuO}_{1} \cdot 50\right\rangle$ & $+0.50\left(\mathrm{H}_{2} \mathrm{O}\right)$ & +15.07 \\
\hline
\end{tabular}

TABLE B-40

REACTIONS BETWEEN $<\mathrm{PuO}_{2}>$ and $\left(\mathrm{H}_{2}\right)$ at $1200{ }^{\circ} \mathrm{K}$

\section{Reaction}

$\left\langle\mathrm{PuO}_{2}\right\rangle+0.02\left(\mathrm{H}_{2}\right)=\left\langle\mathrm{PuO}_{1.98}\right\rangle+0.02\left(\mathrm{H}_{2} \mathrm{O}\right)$ $\left\langle\mathrm{PuO}_{2}\right\rangle+0.05\left(\mathrm{H}_{2}\right)=\left\langle\mathrm{PuO}_{1 \cdot 95}\right\rangle+0.05\left(\mathrm{H}_{2} \mathrm{O}\right)$ $\left\langle\mathrm{PuO}_{2}\right\rangle+0.08\left(\mathrm{H}_{2}\right)=\left\langle\mathrm{PuO}_{1} \cdot 9_{2}\right\rangle+0.08\left(\mathrm{H}_{2} \mathrm{O}\right)$ $\left\langle\mathrm{PuO}_{2}\right\rangle+0.10\left(\mathrm{H}_{2}\right)=\left\langle\mathrm{PuO}_{1 \cdot 90}\right\rangle+0.10\left(\mathrm{H}_{2} \mathrm{O}\right)$ $\left\langle\mathrm{PuO}_{2}\right\rangle+0.15\left(\mathrm{H}_{2}\right)=\left\langle\mathrm{PuO}_{1 \cdot 85}\right\rangle+0.15\left(\mathrm{H}_{2} \mathrm{O}\right)$ $\left\langle\mathrm{PuO}_{2}\right\rangle+0.20\left(\mathrm{H}_{2}\right)=\left\langle\mathrm{PuO}_{1 \cdot 80}\right\rangle+0.20\left(\mathrm{H}_{2} \mathrm{O}\right)$ $\left\langle\mathrm{PuO}_{2}\right\rangle+0.25\left(\mathrm{H}_{2}\right)=\left\langle\mathrm{PuO}_{1.75}\right\rangle+0.25\left(\mathrm{H}_{2} \mathrm{O}\right)$ $\left\langle\mathrm{PuO}_{2}\right\rangle+0.30\left(\mathrm{H}_{2}\right)=\left\langle\mathrm{PuO}_{1} \cdot 70\right\rangle+0.30\left(\mathrm{H}_{2} \mathrm{O}\right)$ $\left\langle\mathrm{PuO}_{2}\right\rangle+0.35\left(\mathrm{H}_{2}\right)=\left\langle\mathrm{PuO}_{1} \cdot 65\right\rangle+0.35\left(\mathrm{H}_{2} \mathrm{O}\right)$ $\left\langle\mathrm{PuO}_{2}\right\rangle+0.39\left(\mathrm{H}_{2}\right)=\left\langle\mathrm{PuO}_{1 \cdot 61}\right\rangle+0.39\left(\mathrm{H}_{2} \mathrm{O}\right)$ $\left\langle\mathrm{PuO}_{2}\right\rangle+0.50\left(\mathrm{H}_{2}\right)=\left\langle\mathrm{PuO}_{1} \cdot 50\right\rangle+0.50\left(\mathrm{H}_{2} \mathrm{O}\right)$ $\triangle \mathrm{G}$

$\mathrm{kcal} / \mathrm{mole}$

$+\quad 0.37$

$+0.99$

$+1.65$

$+2.14$

$+3.45$

$+4.85$

$+6.32$

$+7.93$

$+9.56$

$+10.95$

$+14.67$ 
TABLE B- 41

REACTIONS DETVEEN $<\mathrm{PuO}_{2}>$ and $\left(\mathrm{H}_{2}\right)$ at $2300^{\circ} \mathrm{K}$

\begin{tabular}{|c|c|c|c|}
\hline Ianction & \multirow{3}{*}{ 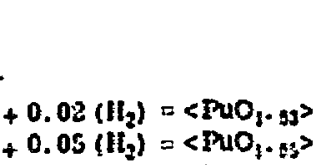 } & \multirow[b]{2}{*}{$\begin{array}{l}+0.02\left(11_{2} \mathrm{O}\right) \\
+0.05\left(11_{2} \mathrm{O}\right)\end{array}$} & $\begin{array}{c}\Delta \mathrm{C} \\
\mathrm{kcxl} / \mathrm{mole}\end{array}$ \\
\hline Pno & & & $\div 0.27$ \\
\hline & & $\begin{array}{l}+0.05\left(1 H_{2} \mathrm{O}\right) \\
+0.03\left(11_{2} \mathrm{O}\right)\end{array}$ & $\begin{array}{l}+0.79 \\
+1.37\end{array}$ \\
\hline & $+0.10(\mathrm{fl})=\left\langle\left[\mathrm{I}_{2} \mathrm{O}_{1} \cdot \mathrm{p}_{9}\right\rangle\right.$ & $\div 0.10(1,0)$ & +2.82 \\
\hline & $+0.15\left(\mathrm{H}_{2}\right)=\left\langle\mathrm{PuO}_{1} \cdot \mathrm{w}^{\prime}\right\rangle$ & $+0.25\left(\mathrm{H}_{2} \mathrm{O}\right)$ & +3.04 \\
\hline & $+0.20\left(\mathrm{II}_{2}\right)=\left\langle\mathrm{PuO}_{1 \cdot \neq 0}\right\rangle$ & $\div 0.20\left(14_{2} \mathrm{O}\right)$ & +4.36 \\
\hline & $\left.+0.25\left(\mathrm{H}_{2}\right)=<\mathrm{PuO}_{1 \cdot 75}\right\rangle$ & $\div 0.25\left[11_{2} \mathrm{O}\right)$ & +5.83 \\
\hline & $+0.30\left(1 \mathrm{I}_{2}\right\rangle=\left\langle 2 \mu \mathrm{O}_{1} \cdot \div 0\right\rangle$ & $+0.30\left(\mathrm{H}_{2} \mathrm{O}\right)$ & +2.45 \\
\hline & $+0.36(\mathrm{HI})=\left\langle\mathrm{PuO}_{\mathrm{g}} \cdot \mathrm{cs}_{9}\right\rangle$ & $+0.35\left(14_{2} \mathrm{O}\right)$ & +9.10 \\
\hline $\begin{array}{l}\mathrm{PuO}_{2} \\
\mathrm{PuO}_{2}\end{array}$ & $\begin{array}{l}+0.39\left(\mathrm{H}_{2}\right)=\left\langle\mathrm{FuO}_{\left.1 \cdot \mathrm{Cl}_{1}\right\rangle}\right. \\
+0.50\left(\mathrm{Hi}_{2}\right)=\left\langle 17 \mathrm{O}_{1} \cdot \mathrm{g}_{2}\right\rangle\end{array}$ & $\begin{array}{l}+0.39\left(12_{2} \mathrm{O}\right) \\
+0.50\left(\theta_{3} \mathrm{O}\right)\end{array}$ & $\begin{array}{l}+10.50 \\
+14.23\end{array}$ \\
\hline & $8000(1+2)$ & & \\
\hline
\end{tabular}

TABLE B-42

REACTIONS BETWEEN $<\mathrm{PuO}_{2}>$ and $\left(\mathrm{fl}_{2}\right)$ at $1400^{\circ} \mathrm{K}$

\section{Reaction}

$\left\langle\mathrm{PuO}_{2}\right\rangle+0.02\left(\mathrm{H}_{2}\right)=\left\langle\mathrm{MuO}_{\mathrm{I}} \cdot \mathrm{H}\right\rangle+0.02\left(\mathrm{II}_{2} \mathrm{O}\right)$

$\left\langle\mathrm{PuO}_{2}\right\rangle+0.05\left(\mathrm{IL}_{2}\right)=\left\langle\mathrm{PuO}_{1} \cdot \mathrm{ss}\right\rangle+0.05\left(\mathrm{IH}_{2} \mathrm{O}\right)$

$\left\langle\mathrm{PuO}_{2}\right\rangle+0.08\left(\mathrm{H}_{2}\right)=\left\langle\mathrm{PuO}_{1} \cdot \mathrm{nn}^{2}\right\rangle+0.08\left(\mathrm{H}_{2} \mathrm{O}\right)$

$\left\langle\mathrm{PuO}_{2}\right\rangle+0.10\left(\mathrm{H}_{2}\right)=\left\langle\mathrm{PuO}_{1} \cdot .90\right\rangle+0.10\left(\mathrm{II}_{2} \mathrm{O}\right)$

$\left\langle\mathrm{PuO}_{2}\right\rangle+0.15\left(\mathrm{H}_{2}\right\rangle=\left\langle\mathrm{PuO}_{\mathrm{I} \cdot \mathrm{AS}}\right\rangle+0.15\left(\mathrm{Il}_{2} \mathrm{O}\right)$

$\left\langle\mathrm{PuO}_{2}\right\rangle+0.20\left(\mathrm{H}_{2}\right\rangle=\left\langle\mathrm{PuO}_{\left.1 \cdot 8_{0}\right\rangle}\right\rangle+0.20\left(\mathrm{H}_{2} \mathrm{O}\right)$

$\left\langle\mathrm{PuO}_{2}\right\rangle+0.25\left(\mathrm{II}_{2}\right)=\left\langle\mathrm{PuO}_{\mid \cdot 75}\right\rangle+0.25\left(\mathrm{H}_{2} \mathrm{O}\right)$

$\left\langle\mathrm{PuO}_{2}\right\rangle+0.30\left(\mathrm{H}_{2}\right)=\left\langle\mathrm{PuO}_{1 \cdot 10}\right\rangle+0.30\left(\mathrm{H}_{2} \mathrm{O}\right)$

$\left\langle\mathrm{PuO}_{2}\right\rangle+0.35\left(\mathrm{H}_{2}\right)=\left\langle\mathrm{PuO}_{1} \cdot \mathrm{CS}\right\rangle+0.35\left(\mathrm{H}_{2} \mathrm{O}\right)$

$\left\langle\mathrm{PuO}_{2}\right\rangle+0.39\left(\mathrm{H}_{2}\right)=\left\langle\mathrm{PuO}_{1} \cdot \mathrm{HI}_{1}\right\rangle+0.39\left(\mathrm{II}_{2} \mathrm{O}\right)$

$\left\langle\mathrm{PuO}_{2}\right\rangle+0.50\left(\mathrm{H}_{2}\right)=\left\langle\mathrm{PuO}_{\mathrm{l} \cdot 50}\right\rangle+0.50\left(\mathrm{H}_{2} \mathrm{O}\right)$
$\Delta \mathbf{C}$

kexi/mole

$+0 .: 7$

$+0.59$

$+1.09$

$+1.49$

$+2.62$

$+3.91$

$+5.35$

$+6.98$

$+8.65$

$+10.06$

$+13.89$ 


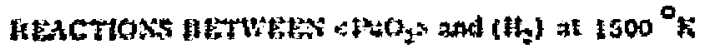

\begin{tabular}{|c|c|c|c|}
\hline teyction & & & $\begin{array}{c}49 \\
\text { kctl/sole }\end{array}$ \\
\hline $\mathrm{MnOO}_{2}=$ & 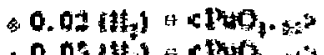 & $0.02(1,0)$ & \\
\hline $\cos 0$ & 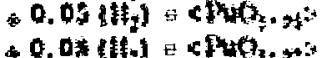 & $\begin{array}{l}-0.03(1+40) \\
* 0.0 \%(t+0)\end{array}$ & * 0.32 \\
\hline 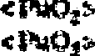 & 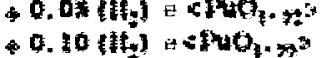 & 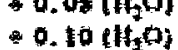 & $\begin{array}{r}0.31 \\
+\quad 1.17\end{array}$ \\
\hline $4 \mathrm{Fu}_{4}^{*}$ & 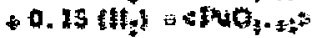 & - 0. $1,(1,0)$ & +2.21 \\
\hline $\operatorname{cts}()_{1}=$ & 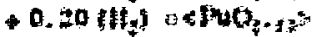 & $0 . \pm 0\left[1 t_{2} \mathrm{O}\right]$ & $\rightarrow 3.44$ \\
\hline $\operatorname{th} 400^{30}$ & 0.23 toty & o. $25[1,0]$ & $\$ 4 . \$ 9$ \\
\hline $\operatorname{cth} \mathrm{O}_{4} 5$ & -0.30 (ft) & $=0.50(149)$ & +6.3 \\
\hline $\mathrm{Cth}_{4}=$ & 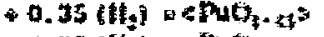 & $0.15(1,9)$ & $=\$ .30$ \\
\hline $\mathrm{CPuO}_{4} 3$ & 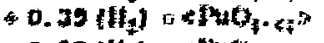 & $=0.79(1,4)$ & $\$ 9.52$ \\
\hline $\cos 6_{4}$ & $+0.50\left(t t_{y}\right)$ e $<t_{4}\left(0_{3} \cdot 1 e^{2}\right.$ & $40.50\left(f_{2} 0\right)$ & $\div 13.50$ \\
\hline
\end{tabular}

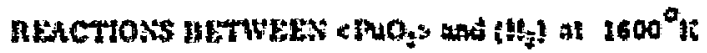

\section{Resction}

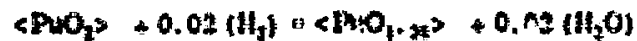

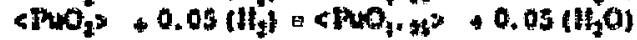

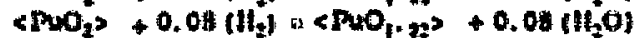

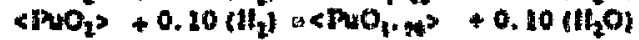

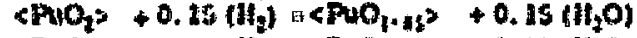

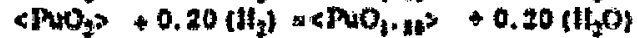

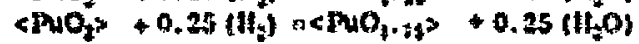

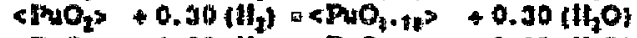

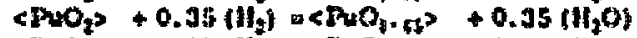

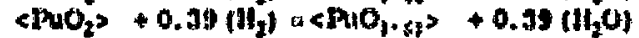
$\left.<\mathrm{HO}_{2}\right\rangle+0.50\left(\mathrm{H}_{2}\right)$ a $<\mathrm{HuO}_{1} \cdot \mathrm{H}^{2}+0.5 \mathrm{H}\left(\mathrm{H} \mathrm{H}_{2} \mathrm{O}\right)$
$\Delta$

sent/mala

$-0.04$

$+0.10$

$+0.33$

$+0.65$

$+\quad 1.75$

$+2.87$

$+4.10$

$+6.04$

$+7.75$

$+9.19$

$+13.12$ 
TADIFE B-45

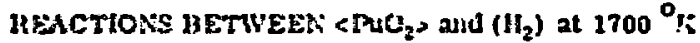

\begin{tabular}{|c|c|c|c|}
\hline Meaction & & \multirow[b]{2}{*}{$\begin{array}{l}+0.02\left(11_{2} \mathrm{O}\right) \\
+0.05\left(11_{2} \mathrm{O}\right)\end{array}$} & $\begin{array}{c}\Delta \mathbf{G} \\
\text { kcal/molo }\end{array}$ \\
\hline $\begin{array}{l}<\mathrm{WuO}_{2} \mathrm{~S} \\
\text { climoss }\end{array}$ & 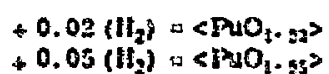 & & $\begin{array}{l}-0.14 \\
-0.02\end{array}$ \\
\hline$\left.<\mathrm{PuO}_{7}\right\rangle$ & $+0.05\left(1 t_{4}\right)$ u $<\mathrm{hu} 0_{1.92}$ & $+0.68\left(\mathrm{H}_{2} \mathrm{O}\right)$ & +0.25 \\
\hline$\left\langle\mathrm{PuO}_{4}\right\rangle$ & $\left.\$ 0.10\left(\mathrm{H}_{3}\right)=<\mathrm{PuO}_{4} \cdot 9\right\rangle$ & $+0.10\left(11_{2} \mathrm{O}\right)$ & +0.53 \\
\hline$\left\langle\mathrm{PHO}_{2}\right\rangle$ & $\left.+0.15\left(1 H_{3}\right)=<\mathrm{P}_{1} \mathrm{O}_{1+23}\right\rangle$ & $+0.15\left(11_{2} 0\right)$ & +1.38 \\
\hline$\left.\angle \mathrm{PuO}_{2}\right\rangle$ & $+0.20\left(11_{2}\right)=\left(\mathrm{PLO}_{4} \cdot \mathrm{I}_{2} \mathrm{~s}\right.$ & $+0.20\left(\mathrm{H}_{2} \mathrm{O}\right)$ & +2.51 \\
\hline $\mathrm{HuO}_{2}$ & $+0.25\left(\mathrm{H}_{2}\right)$ o<MtO $\left.\mathrm{O}_{13}\right\rangle$ & $+0.25\left\{11_{2} \mathrm{O}\right\}$ & +3.92 \\
\hline$\$ \mathrm{fuO}_{2} \mathrm{P}$ & 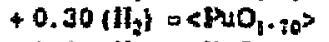 & $+0.30\left(1 \mathrm{H}_{2} \mathrm{O}\right)$ & +5.58 \\
\hline$\left.<\mathrm{wOS}_{1}\right\rangle$ & 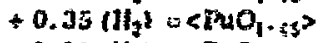 & $+0.35\left(1 t_{2} \mathrm{O}\right)$ & +7.30 \\
\hline $\mathrm{NuO}_{2}$ & $+0.39\left\{\left(f_{2}\right\}=6 \mathrm{PHO}_{1} \cdot \mathrm{c}\right\}$ & $+0.39\left(1 \mathrm{H}_{2} \mathrm{O}\right)$ & +8.76 \\
\hline & $\left.+0.50(1)_{3}\right)$ o $\left.<14 O_{1}, 5\right\rangle$ & $-0.50\left(x_{2} \mathrm{O}\right)$ & +12.74 \\
\hline
\end{tabular}

IEACTONS UETHEEN $C$ PuO $\mathrm{O}_{2}$ s and $\left(\mathrm{II}_{2}\right)$ at $2800^{\circ} \mathrm{K}$

\section{Daction}

$\left\langle\mathrm{MHO}_{7}\right\rangle+0.02\left(\mathrm{H}_{2}\right)=\left(\mathrm{PuO}_{1} \cdot \mathrm{H}\right\rangle+0.02\left(\mathrm{H}_{2} \mathrm{O}\right)$

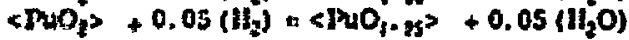

$\left.\left.<\mathrm{MOO}_{2}\right\rangle+0.08\left(\mathrm{H}_{2}\right)=<\mathrm{BuO}_{1} \cdot \mathrm{n}_{2}\right\rangle+0.08\left(\mathrm{H}_{2} \mathrm{O}\right)$

$\left\langle\mathrm{BuO}_{2}\right\rangle+0.10\left(1 \mathrm{H}_{2}\right)=\left\langle\left(t u \mathrm{O}_{1+20}\right\rangle+0.10\left(1 \mathrm{H}_{2} \mathrm{O}\right)\right.$

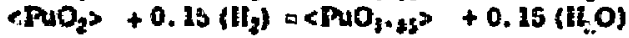

$\left.<\mathrm{MuO}_{2}\right\rangle+0.20\left(1 \mathrm{l}_{2}\right)+\mathrm{MuO}_{4}-\mathrm{H}^{2}+0.20\left\langle\mathrm{H}_{2} \mathrm{O}\right)$

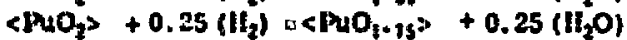

$\left\langle\mathrm{PuO}_{2}\right\rangle+0.30\left(\mathrm{H}_{2}\right)=\left\langle\left(\mathrm{uO}_{1}-10^{3}+0.30\left(\mathrm{H}_{2} \mathrm{O}\right)\right.\right.$

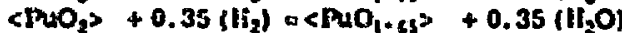

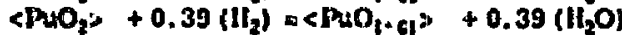

$<\mathrm{PuO}_{2} 3+0.50\left(\mathrm{H}_{2}\right)=<\left(4 \mathrm{O}_{1}+5\right)^{2}+0.50\left(1 \mathrm{I}_{2} \mathrm{O}\right)$
$\Delta \mathbf{G}$

kcal/mole

$-0.21$

$-0.22$

$-0.03$

$+0.20$

$+0.96$

$+2.05$

$+3.46$

$+5.12$

$+6.85$

$+8.32$

$+12.36$ 
REACTIONS BETWEEN $<\mathrm{PuO}_{2}>$ and $\left(\mathrm{H}_{2}\right)$ at $1900{ }^{\circ} \mathrm{K}$

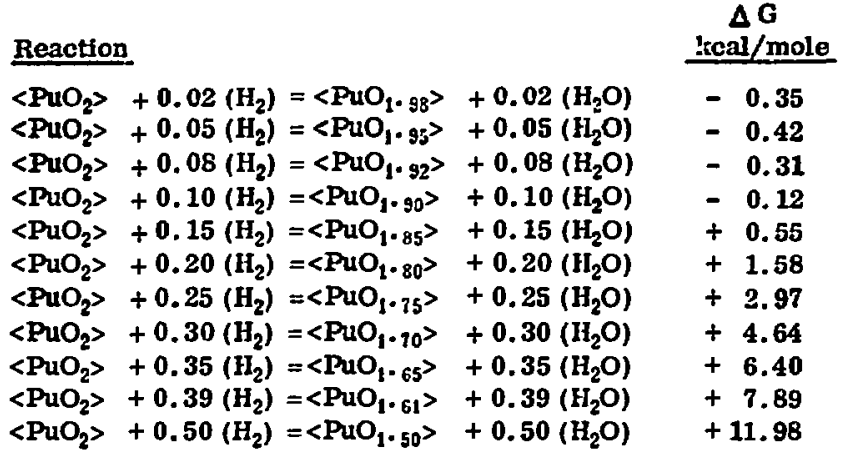

REACTIONS BETWEEN $<\mathrm{PuO}_{2}>$ and $\left(\mathrm{H}_{2}\right)$ at $2000^{\circ} \mathrm{K}$

\section{Reaction}

$\left\langle\mathrm{PuO}_{2}\right\rangle+0.02\left(\mathrm{H}_{2}\right)=\left\langle\mathrm{PuO}_{1.98}\right\rangle+0.02\left(\mathrm{H}_{2} \mathrm{O}\right)$ $\left\langle\mathrm{PuO}_{2}\right\rangle+0.05\left(\mathrm{H}_{2}\right)=\left\langle\mathrm{PuO}_{1} \cdot 95\right\rangle+0.05\left(\mathrm{H}_{2} \mathrm{O}\right)$ $\left\langle\mathrm{PuO}_{2}\right\rangle+0.08\left(\mathrm{H}_{2}\right)=\left\langle\mathrm{PuO}_{1 \cdot 92}\right\rangle+0.08\left(\mathrm{H}_{2} \mathrm{O}\right)$ $\left\langle\mathrm{PuO}_{2}\right\rangle+0.10\left(\mathrm{H}_{2}\right)=\left\langle\mathrm{PuO}_{1} \cdot 90^{2}\right\rangle+0.10\left(\mathrm{H}_{2} \mathrm{O}\right)$ $\left\langle\mathrm{PuO}_{2}\right\rangle+0.15\left(\mathrm{H}_{2}\right)=\left\langle\mathrm{PuO}_{1} \cdot \mathrm{B5}\right\rangle+0.15\left(\mathrm{H}_{2} \mathrm{O}\right)$ $\left\langle\mathrm{PuO}_{2}\right\rangle+0.20\left(\mathrm{H}_{2}\right)=\left\langle\mathrm{PuO}_{1 \cdot 80}\right\rangle+0.20\left(\mathrm{H}_{2} \mathrm{O}\right)$ $\left\langle\mathrm{PuO}_{2}\right\rangle+0.25\left(\mathrm{H}_{2}\right)=\left\langle\mathrm{PuO}_{1 \cdot 75}\right\rangle+0.25\left(\mathrm{H}_{2} \mathrm{O}\right)$ $\left\langle\mathrm{PuO}_{2}\right\rangle+0.30\left(\mathrm{H}_{2}\right)=\left\langle\mathrm{PuO}_{1} \cdot 10\right\rangle+0.30\left(\mathrm{H}_{2} \mathrm{O}\right)$ $\left\langle\mathrm{PuO}_{2}\right\rangle+0.35\left(\mathrm{H}_{2}\right)=\left\langle\mathrm{PuO}_{1 \cdot 65}\right\rangle+0.35\left(\mathrm{H}_{2} \mathrm{O}\right)$ $\left\langle\mathrm{PuO}_{2}\right\rangle+0.39\left(\mathrm{H}_{2}\right)=\left\langle\mathrm{PuO}_{1 \cdot 61}\right\rangle+0.39\left(\mathrm{H}_{2} \mathrm{O}\right)$ $\left\langle\mathrm{PuO}_{2}\right\rangle+0.50\left(\mathrm{H}_{2}\right)=\left\langle\mathrm{PuO}_{1 \cdot 50}\right\rangle+0.50\left(\mathrm{H}_{2} \mathrm{O}\right)$
$\Delta \mathbf{G}$ kcal/mole

$-0.45$

- 0.62

$-0.59$

$-0.44$

$+0.14$

$+1.12$

$+2.50$

$+4.18$

$+5.96$

$+7.46$

$+11.60$ 
TABLE B-49

REACTIONS BETWEEN $<\mathrm{PuO}_{2}>$ and $\left(\mathrm{H}_{2}\right)$ at $2100{ }^{\circ} \mathrm{K}$

\begin{tabular}{|c|c|c|c|}
\hline \multicolumn{3}{|c|}{ Reaction } & $\begin{array}{c}\Delta \mathrm{G} \\
\mathrm{kcal} / \mathrm{mole}\end{array}$ \\
\hline $\begin{array}{l}\left.<\mathrm{PuO}_{2}\right\rangle \\
\left\langle\mathrm{PuO}_{2}\right\rangle\end{array}$ & $\begin{array}{l}+0.02\left(\mathrm{H}_{2}\right)=\left\langle\mathrm{PuO}_{1 \cdot 98}\right\rangle \\
+0.05\left(\mathrm{H}_{2}\right)=\left\langle\mathrm{PuO}_{1.95}\right\rangle\end{array}$ & $\begin{array}{l}+0.02\left(\mathrm{H}_{2} \mathrm{O}\right) \\
+0.05\left(\mathrm{H}_{2} \mathrm{O}\right)\end{array}$ & $\begin{array}{l}-\quad 0.55 \\
-\quad 0.82\end{array}$ \\
\hline$<\mathrm{PuO}_{2}>$ & $+0.08\left(\mathrm{H}_{2}\right)=\left\langle\mathrm{PuO}_{1} \cdot 92\right\rangle$ & $+0.08\left(\mathrm{H}_{2} \mathrm{O}\right)$ & -0.87 \\
\hline$\left\langle\mathrm{PuO}_{2}\right\rangle$ & $+0.10\left(\mathrm{H}_{2}\right)=\left\langle\mathrm{PuO}_{1 \cdot 90}\right\rangle$ & $+0.10\left(\mathrm{H}_{2} \mathrm{O}\right)$ & -0.76 \\
\hline$\left\langle\mathrm{PuO}_{2}\right\rangle$ & $+0.15\left(\mathrm{H}_{2}\right)=\left\langle\mathrm{PuO}_{1 \cdot 85}\right\rangle$ & $+0.15\left(\mathrm{H}_{2} \mathrm{O}\right)$ & -0.27 \\
\hline$\left\langle\mathrm{PuO}_{2}\right\rangle$ & $+0.20\left(\mathrm{H}_{2}\right)=\left\langle\mathrm{PuO}_{1 \cdot 80}\right\rangle$ & $+0.20\left(\mathrm{H}_{2} \mathrm{O}\right)$ & +0.65 \\
\hline$\left\langle\mathrm{PuO}_{2}\right\rangle$ & $+0.25\left(\mathrm{H}_{2}\right)=\left\langle\mathrm{PuO}_{1 \cdot 75}\right\rangle$ & $+0.25\left(\mathrm{H}_{2} \mathrm{O}\right)$ & +2.03 \\
\hline$\left\langle\mathrm{PuO}_{2}\right\rangle$ & $+0.30\left(\mathrm{IH}_{2}\right)=\left\langle\mathrm{PuO}_{1 \cdot 10}\right\rangle$ & $+0.30\left(\mathrm{H}_{2} \mathrm{O}\right)$ & +3.72 \\
\hline$\left\langle\mathrm{PuO}_{2}\right\rangle$ & A. $0.35\left(\mathrm{H}_{2}\right)=\left\langle\mathrm{PuO}_{1} .65\right\rangle$ & $+0.35\left(\mathrm{H}_{2} \mathrm{O}\right)$ & +5.52 \\
\hline$\left.<\mathrm{PuO}_{2}\right\rangle$ & $+0.39\left(\mathrm{H}_{2}\right)=\left\langle\mathrm{PuO}_{1} \cdot \mathrm{G1}\right\rangle$ & $+0.39\left(\mathrm{H}_{2} \mathrm{O}\right)$ & +7.04 \\
\hline & $+0.50\left(\mathrm{H}_{2}\right)=\left\langle\mathrm{PuO}_{1 \cdot 50}\right\rangle$ & $+0.50\left(\mathrm{H}_{2} \mathrm{O}\right)$ & +11.22 \\
\hline
\end{tabular}

TABLE B-50

REACTIONS BETWEEN $<\mathrm{PuO}_{2}>$ and $\left(\mathrm{H}_{2}\right)$ at $2200{ }^{\circ} \mathrm{K}$

\begin{tabular}{|c|c|c|c|}
\hline \multicolumn{3}{|c|}{ Reaction } & $\begin{array}{c}\Delta G \\
\mathrm{kcal} / \mathrm{mole} \\
\end{array}$ \\
\hline $\begin{array}{l}\left\langle\mathrm{PuO}_{2}\right\rangle \\
\left\langle\mathrm{PuO}_{2}\right\rangle\end{array}$ & $\begin{aligned}+0.02\left(\mathrm{H}_{2}\right) & =\left\langle\mathrm{PuO}_{1 \cdot 98}\right\rangle \\
+0.05\left(\mathrm{H}_{2}\right) & =\left\langle\mathrm{PuO}_{1} \cdot \mathrm{gs5}_{5}\right\rangle\end{aligned}$ & $\begin{array}{l}+0.02\left(\mathrm{H}_{2} \mathrm{O}\right) \\
+0.05\left(\mathrm{H}_{2} \mathrm{O}\right)\end{array}$ & $\begin{array}{l}-0.65 \\
-\quad 1.02\end{array}$ \\
\hline$\left\langle\mathrm{PuO}_{2}\right\rangle$ & $+0.08\left(\mathrm{H}_{2}\right)=\left\langle\mathrm{PuO}_{1} \cdot 92\right\rangle$ & $+0.08\left(\mathrm{H}_{2} \mathrm{O}\right)$ & $-1,15$ \\
\hline$\left\langle\mathrm{PuO}_{2}\right\rangle$ & $+0.10\left(\mathrm{H}_{2}\right)=\left\langle\mathrm{PuO}_{1} \cdot 90^{\prime}\right\rangle$ & $+0.10\left(\mathrm{H}_{2} \mathrm{O}\right)$ & -1.08 \\
\hline$\left\langle\mathrm{PuO}_{2}\right\rangle$ & $+0.15\left(\mathrm{H}_{2}\right)=\left\langle\mathrm{PuO}_{1} \cdot \mathrm{BS}\right\rangle$ & $+0.15\left(\mathrm{H}_{2} \mathrm{O}\right)$ & -0.68 \\
\hline$\left\langle\mathrm{PuO}_{2}\right\rangle$ & $+0.20\left(\mathrm{H}_{2}\right)=\left\langle\mathrm{PuO}_{1 \cdot 80}\right\rangle$ & $+0.20\left(\mathrm{I}_{2} \mathrm{O}\right)$ & +0.20 \\
\hline$\left\langle\mathrm{PuO}_{2}\right\rangle$ & $+0.25\left(\mathrm{H}_{2}\right)=\left\langle\mathrm{PuO}_{1 \cdot 75}\right\rangle$ & $+0.25\left(\mathrm{H}_{2} \mathrm{O}\right)$ & +1.55 \\
\hline$\left\langle\mathrm{PuO}_{2}\right\rangle$ & $+0.30\left(\mathrm{H}_{2}\right)=\left\langle\mathrm{PuO}_{1 \cdot 70}\right\rangle$ & $+0.30\left(\mathrm{H}_{2} \mathrm{O}\right)$ & +3.25 \\
\hline$\left\langle\mathrm{PuO}_{2}\right\rangle$ & $+0.35\left(\mathrm{H}_{2}\right)=\left\langle\mathrm{PuO}_{1.65}\right\rangle$ & $+0.35\left(\mathrm{H}_{2} \mathrm{O}\right)$ & +5.07 \\
\hline$\left\langle\mathrm{PuO}_{2}\right\rangle$ & $+0.39\left(\mathrm{H}_{2}\right)=\left\langle\mathrm{PuO}_{1 \cdot 61}\right\rangle$ & $+0.39\left(\mathrm{H}_{2} \mathrm{O}\right)$ & +6.61 \\
\hline$\left\langle\mathrm{PuO}_{2}\right\rangle$ & $+0.50\left(\mathrm{H}_{2}\right)=\left\langle\mathrm{P}_{1} \mathrm{O}_{1 \cdot 50}\right\rangle$ & $+0.50\left(\mathrm{H}_{2} \mathrm{O}\right)$ & +10.85 \\
\hline
\end{tabular}


TABLE B- 51

REACTIONS BETWEEN $<$ PUO ${ }_{2}>$ and $\left(\mathrm{II}_{2}\right)$ at $2300^{\circ} \mathrm{K}$

\section{Roaction}

$$
\begin{aligned}
& \left\langle\mathrm{PuO}_{2}\right\rangle+0.02\left(\mathrm{H}_{2}\right)=\left\langle\mathrm{PuO}_{1} \cdot \mathrm{gss}_{5}\right\rangle+0.02\left(\mathrm{H}_{2} \mathrm{O}\right) \\
& \left\langle\mathrm{PuO}_{2}\right\rangle+0.05\left(\mathrm{H}_{2}\right)=\left\langle\mathrm{PuO}_{1} \cdot 35\right\rangle+0.05\left(\mathrm{H}_{2} \mathrm{O}\right) \\
& \left\langle\mathrm{PuO}_{2}\right\rangle+0.08\left(\mathrm{H}_{2}\right)=\left\langle\mathrm{PuO}_{1} \cdot \mathrm{s2}_{2}\right\rangle+0.08\left(\mathrm{H}_{2} \mathrm{O}\right) \\
& \left.-\mathrm{PuO}_{2}\right\rangle+0.10\left(\mathrm{It}_{2}\right)=\left\langle\mathrm{PuO}_{1.50}\right\rangle+0.10\left(\mathrm{Hl}_{2} \mathrm{O}\right) \\
& \left\langle\mathrm{PuO}_{2}\right\rangle+0.15\left(\mathrm{II}_{2}\right)=\left\langle\mathrm{PuO}_{2} \cdot 85\right\rangle+0.15\left(\mathrm{H}_{2} \mathrm{O}\right) \\
& \left\langle\mathrm{PuO}_{2}\right\rangle+0.20\left(\mathrm{HI}_{2}\right)=\left\langle\mathrm{PuO}_{1 \cdot 80}\right\rangle+0.20\left(\mathrm{Il}_{2} \mathrm{O}\right) \\
& \left\langle\mathrm{PuO}_{2}\right\rangle+0.25\left(\mathrm{H}_{2}\right)=\left\langle\mathrm{PuO}_{1 \cdot 35}\right\rangle+0.25\left(\mathrm{H}_{2} \mathrm{O}\right) \\
& \left\langle\mathrm{PuO}_{2}\right\rangle+0.30\left(\mathrm{H}_{2}\right)=\left\langle\mathrm{PuO}_{1 \cdot 70}\right\rangle+0.30\left(\mathrm{H}_{2} \mathrm{O}\right) \\
& \left\langle\mathrm{PuO}_{2}\right\rangle+0.35\left(\mathrm{H}_{2}\right)=\left\langle\mathrm{PuO}_{1.65}\right\rangle+0.35\left(\mathrm{H}_{2} \mathrm{O}\right) \\
& \left\langle\mathrm{PuO}_{2}\right\rangle+0.39\left(\mathrm{H}_{2}\right)=\left\langle\mathrm{PuO}_{1 \cdot 61}\right\rangle \div 0.39\left(\mathrm{~K}_{2} \mathrm{O}\right) \\
& \left\langle\mathrm{PuO}_{2}\right\rangle+0.50\left(\mathrm{H}_{2}\right)=\left\langle\mathrm{HuO}_{1} \cdot 50\right\rangle+0.50\left(1 \mathrm{H}_{2} \mathrm{O}\right)
\end{aligned}
$$

$\Delta G$

keal/mole

- 0.75

$-1.22$

$-1.43$

$-1.40$

- 1.09

$-0.27$

$+1.08$

$+2.79$

$+4.63$

$+6.18$

$+10.48$

REACTIONS BETWEEN < $\mathrm{PuO}_{2}>$ and <Ir> at $298^{\circ} \mathrm{K}$

Reaction

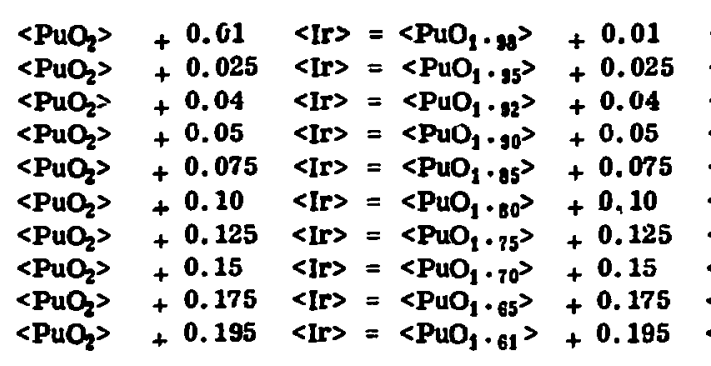

$\Delta \mathbf{G}$

keal/mole

$\left.<\mathrm{IrO}_{2}\right\rangle$

$\left\langle\mathrm{IrO}_{2}\right\rangle$

$\left\langle\mathrm{IrO}_{2}\right\rangle$

$\left\langle\mathrm{IrO}_{2}\right.$ >

$\left\langle\mathrm{IrO}_{2}\right\rangle$

$\left.<\mathrm{IrO}_{2}\right\rangle$

$<\mathrm{IrO}_{2}>$

$\left\langle\mathrm{IrO}_{2}\right\rangle$

$<\mathrm{IrO}_{2}>$

$\left.<\mathrm{IrO}_{2}\right\rangle$ $+\quad 1.96$

$+\quad 4.46$

$+\quad 6.83$

$+8.37$

$+\quad 12.17$

$+15.68$

$+\quad 18.92$

$+22.11$

$+25.23$

$+\quad 27.81$ 
TABLE $\mathbf{B}-\mathbf{5 3}$

REACTIONS BETWEEN $<$ PuO $_{2}>$ and $<$ Ir $>$ at $500^{\circ} \mathrm{K}$

Reaction

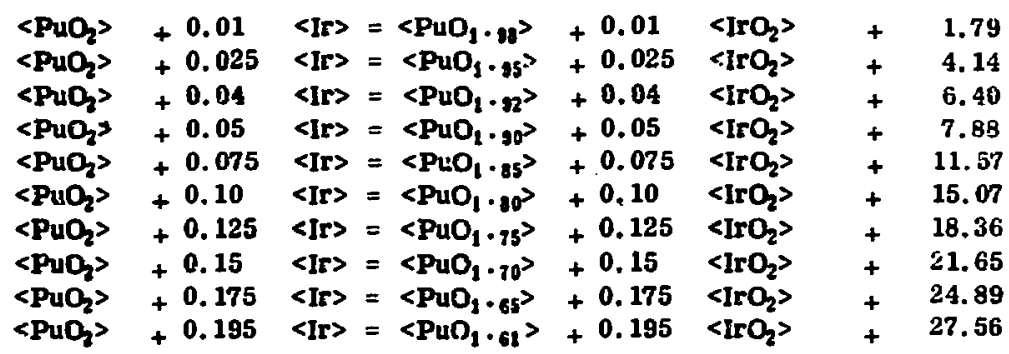

G

kcal/mole

1.79

4.14

07

18,36

4.89

27.56

\section{Reaction}

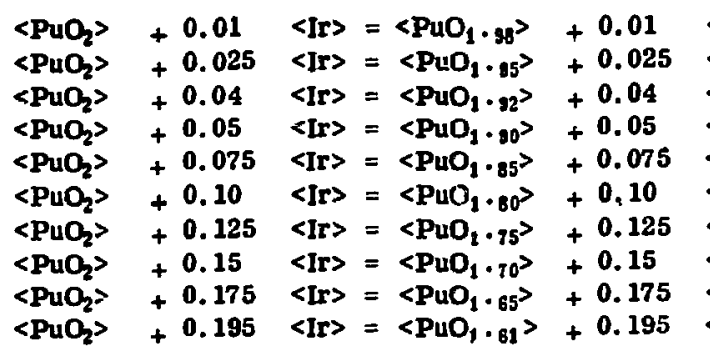

\section{REACTIONS BEIWBEN $<$ PuO $>$ and $<$ Ir $>$ at $800^{\circ} \mathrm{K}$}


Reaction

\begin{tabular}{|c|c|c|c|c|c|c|c|}
\hline$\left\langle\mathrm{PuO}_{2}\right\rangle$ & +0.01 & $\langle\operatorname{Ir}\rangle$ & $=\left\langle\mathrm{PuO}_{1} \cdot 9_{8}\right\rangle$ & +0.01 & $\left\langle\mathrm{IrO}_{2}\right\rangle$ & + & 1.35 \\
\hline$\left.<\mathrm{PuO}_{2}\right\rangle$ & +0.025 & $<$ Ir $>$ & $=\left\langle\mathrm{PuO}_{1} \cdot 95\right\rangle$ & +0.025 & $\left\langle I r \mathrm{O}_{2}\right\rangle$ & & 3.34 \\
\hline $\mathrm{dO}_{2}>$ & +0.04 & $\langle$ Ir $\rangle$ & $=\left\langle\mathrm{PuO}_{1} \cdot \mathrm{9}_{2}\right\rangle$ & +0.04 & $<$ IrO & & 5.32 \\
\hline & +0.05 & $\langle\mathbf{I} \mathbf{|}\rangle$ & $=\left\langle\mathrm{PuO}_{1} \cdot \mathbf{9 0}\right\rangle$ & +0.05 & $<$ & + & 6.67 \\
\hline$<\mathrm{PuO}_{2}$ & +0.075 & $<\mathrm{Ir}$ & $=\left\langle\mathrm{PuO}_{1} \cdot 85\right\rangle$ & +0.075 & $\left\langle\mathrm{IrO}_{2}\right\rangle$ & + & 10.11 \\
\hline$\left\langle\mathrm{PuO}_{2}\right\rangle$ & +0.10 & $<\operatorname{lr}\rangle$ & $=\left\langle\mathrm{PuO}_{1} \cdot 80^{\rangle}\right\rangle$ & +0.10 & $<1$ & + & 13.54 \\
\hline$P$ & +0.125 & IIr & $=\left\langle\mathrm{PuO}_{1} \cdot 75\right\rangle$ & +0.125 & $\left\langle\mathrm{IrO}_{2}\right\rangle$ & + & 16.98 \\
\hline $\mathrm{PuO}_{2}$ & +0.15 & $<I r$ & $=\left\langle\mathrm{PuO}_{1} \cdot 70^{\rangle}\right.$ & +0.15 & $\left\langle\operatorname{IrO}_{2}\right\rangle$ & + & 20.51 \\
\hline $\mathrm{uO}_{2}>$ & +0.175 & $\langle\operatorname{Ir}\rangle$ & $=\left\langle\mathrm{PuO}_{1} \cdot 65\right\rangle$ & +0.175 & & + & 24.05 \\
\hline & +0.195 & 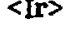 & $=\left\langle\mathrm{PuO}_{1 \cdot 61}\right\rangle$ & +0.195 & $\left\langle\mathrm{IrO}_{2}\right\rangle$ & $T$ & 26.96 \\
\hline
\end{tabular}

$\Delta^{G}$

kcal/mole

TABLE $B-56$

REACTIONS BETWEEN $<\mathrm{PuO}_{2}>$ and $<$ Ir $>$ at $1100^{\circ} \mathrm{K}$

$\underline{\text { Reaction }}$

$\Delta^{\mathrm{G}}$

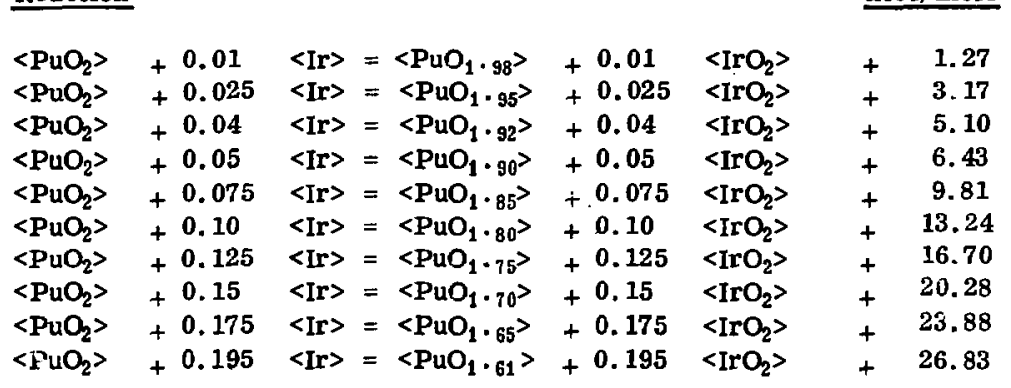


TABLE B - 57

REACTIONS BETWEEN $<$ PuO $_{2}>$ and $<$ Ir $>$ at $1200^{\circ} \mathrm{K}$

Reaction

\begin{tabular}{|c|c|c|c|c|c|c|c|}
\hline$\left.<\mathrm{PuO}_{2}\right\rangle$ & +0.01 & $\langle$ Ir $>$ & $=\left\langle\mathrm{PuO}_{1} \cdot 98\right\rangle$ & +0.01 & $\left\langle\mathbf{I r O} \mathrm{O}_{2}\right\rangle$ & + & 1.18 \\
\hline$\left\langle\mathrm{PuO}_{2}\right\rangle$ & +0.025 & $\langle\operatorname{lr}\rangle$ & $=\left\langle\mathrm{PuO}_{1} \cdot 95\right\rangle$ & +0.025 & $\left\langle\mathrm{IrO}_{2}\right\rangle$ & + & 3.01 \\
\hline$\left\langle\mathrm{PuO}_{2}\right\rangle$ & +0.04 & $\langle\operatorname{lr}\rangle$ & $=\left\langle\mathrm{PuO}_{1} \cdot \mathrm{g2}\right\rangle$ & +0.04 & $\left\langle\operatorname{IrO}_{2}\right\rangle$ & + & 4.88 \\
\hline$\left\langle\mathrm{PuO}_{2}\right\rangle$ & +0.05 & $\langle$ Ir $\rangle$ & $=\left\langle\mathrm{PuO}_{1} \cdot \mathrm{90}\right\rangle$ & +0.05 & $\left\langle\mathrm{IrO}_{2}\right\rangle$ & + & 6.19 \\
\hline$\left\langle\mathrm{PuO}_{2}\right\rangle$ & +0.075 & $<\mathrm{Ir}$ & $=\left\langle\mathrm{PuO}_{1} \cdot 85\right\rangle$ & +0.075 & $\left\langle\mathrm{IrO}_{2}\right\rangle$ & + & 9.52 \\
\hline $\mathrm{PuO}_{2}>$ & +0.10 & $\langle\operatorname{lr}\rangle$ & $=\left\langle\mathrm{PuO}_{1} \cdot \theta_{00}\right\rangle$ & +0.10 & $\left\langle\mathrm{IrO}_{2}\right\rangle$ & + & 12.93 \\
\hline $\mathrm{PuO}_{2}>$ & +0.125 & $<\operatorname{Ir}>$ & $=\left\langle\mathrm{PuO}_{1} \cdot 7 \mathrm{~b}\right\rangle$ & +0.125 & $\left.<\mathrm{IrO}_{2}\right\rangle$ & + & 16.42 \\
\hline $\mathrm{PuO}_{2}>$ & +0.15 & $<$ Ir & $=\left\langle D_{\mathrm{uO}} \cdot \mathbf{7 0}_{10}\right\rangle$ & +0.15 & $\left\langle\mathrm{IrO}_{2}\right\rangle$ & + & 20.06 \\
\hline $\mathrm{PuO}_{2}$ & +0.175 & $<$ Ir & $=\left\langle .4 O_{1} \cdot 65^{\prime}\right\rangle$ & +0.175 & $\left\langle\mathrm{IrO}_{2}\right\rangle$ & + & 23.71 \\
\hline $\mathrm{PuO}_{2}$ & +0.195 & $\mathrm{~T}$ & $=\left\langle\mathrm{PuO}_{1} \cdot 61\right\rangle$ & $\div 0.195$ & $\left\langle\operatorname{Ir} \mathrm{O}_{2}\right\rangle$ & + & 26.71 \\
\hline
\end{tabular}

$\Delta \mathbf{G}$

kcal/mole

18

88

19

.93

06

\section{TABLE B - 58}

REACTIONS BETWEEN $<$ PuO $_{2}>$ and $<$ Ir $>$ at $1300{ }^{\circ} \mathrm{K}$

$\underline{\text { Reaction }}$

\begin{tabular}{|c|c|c|c|c|c|}
\hline $\mathrm{PuO}_{2}>$ & +0.01 & $\langle\operatorname{Ir}\rangle$ & $=\left\langle\mathrm{PuO}_{1} \cdot{ }_{98}\right\rangle$ & +0.01 & $\left\langle\mathrm{IrO}_{2}\right\rangle$ \\
\hline $\mathrm{PuO}_{2}>$ & 0.025 & Ir & $=\left\langle\mathrm{PuO}_{1} \cdot 95\right\rangle$ & .025 & 0 \\
\hline $\mathrm{PuO}_{2}>$ & +0.04 & Ir & $=\left\langle\mathrm{PuC}_{1} \cdot \mathrm{92}\right\rangle$ & +0.04 & $\left\langle\mathrm{IrO}_{2}\right\rangle$ \\
\hline $\mathrm{PuO}_{2}>$ & 1. & Ir $>$ & $=\left\langle\mathrm{PuO}_{1} \cdot 90^{\rangle}\right.$ & $T$ & $\left.<\mathrm{IrO}_{2}\right\rangle$ \\
\hline $\mathrm{PuO}_{2}$ & +0.075 & Ir & $=\left\langle\mathrm{PuO}_{1} \cdot{ }_{85}\right\rangle$ & +0.075 & $\left\langle\mathrm{IrO}_{2}\right\rangle$ \\
\hline $\mathrm{PuO}_{2}>$ & +0.10 & Ir & $=\left\langle\mathrm{PuO}_{1} \cdot \mathrm{g}_{0}\right\rangle$ & +0.10 & $<\operatorname{Ir}$ \\
\hline $\mathrm{PuO}_{2}$ & + & $<\operatorname{Ir}\rangle$ & $=\left\langle\mathrm{PuO}_{1} \cdot 75\right\rangle$ & +0.125 & $\left\langle\mathrm{IrO}_{2}\right\rangle$ \\
\hline $\mathrm{PuO}_{2}$ & + & <Ir & $=<\mathrm{PuO}_{1}$ & + & $2_{2}$ \\
\hline & 35 & & $=<\mathrm{PuO}$ & + & \\
\hline $\mathbf{P u}$ & 195 & & $=\left\langle\mathrm{PuO}_{1}\right.$ & .195 & \\
\hline
\end{tabular}

$\Delta \mathrm{G}$

kcal/mole

$+\quad 1.09$
$+\quad 2.85$
$+\quad 4.67$
$+\quad 5.94$
$+\quad 9.22$
$+\quad 12.63$
$+\quad 16.15$
$+\quad 19.83$
$+\quad 23.54$
$+\quad 26.59$


REACTIONS TO FORM ( IrO $_{2}$ ) at $100{ }^{\circ \mathrm{K}}$

Reactions

\begin{tabular}{|c|c|}
\hline$\left\langle\mathrm{PuO}_{2}\right\rangle$ & +0.01 \\
\hline$\left.<\mathrm{PuO}_{2}\right\rangle$ & +0.025 \\
\hline $\begin{array}{l}\left.<\mathrm{PuO}_{2}\right\rangle \\
\left\langle\mathrm{PuO}_{2}\right\rangle\end{array}$ & $\begin{array}{r}+0.04 \\
+0.05\end{array}$ \\
\hline$\left\langle\mathrm{PuO}_{2}\right\rangle$ & +0.075 \\
\hline$<\mathrm{PuO}_{2}$ & +0.10 \\
\hline$\left\langle\mathrm{PuO}_{2}\right\rangle$ & +0.125 \\
\hline $\mathrm{PuO}_{2}>$ & +0.15 \\
\hline $\begin{array}{l}=\mathrm{PuO}_{2}> \\
=\mathrm{PuO}_{2}>\end{array}$ & $\begin{array}{r}0.175 \\
+0.195\end{array}$ \\
\hline$\left\langle\mathrm{PuO}_{2}\right\rangle$ & +0.25 \\
\hline
\end{tabular}

$\langle\mathrm{Ir}\rangle=\left\langle\mathrm{PuO}_{1} \cdot{ }_{98}\right\rangle+0.01 \quad(\mathrm{IrO})$

$\langle\mathrm{Ir}\rangle=\left\langle\mathrm{PuO}_{1} \cdot 95\right\rangle+0.025 \quad\left(\mathrm{IrO}_{2}\right)$

$\langle\mathrm{Ir}\rangle=\left\langle\mathrm{PuO}_{\mathrm{t}} \cdot 92\right\rangle+0.04 \quad\left(\mathrm{IrO}_{2}\right)$

$\langle\mathrm{Ir}\rangle=\left\langle\mathrm{PuO}_{1 \cdot 90}\right\rangle+0.05 \quad\left(\mathrm{IrO}_{2}\right)$

$\langle\mathrm{Ir}\rangle=\left\langle\mathrm{PuO}_{1} \cdot 85\right\rangle+0.075\left(\mathrm{IrO}_{2}\right)$

$\langle\mathrm{Ir}\rangle=\left\langle\mathrm{PuO}_{1 \cdot 80}\right\rangle+0.10 \quad\left(\mathrm{IrO}_{2}\right)$

$\langle\mathrm{Ir}\rangle=\left\langle\mathrm{PuO}_{1} \cdot 75\right\rangle+0.125\left(\mathrm{IrO}_{2}\right)$

$\langle$ Ir $\rangle=\left\langle\mathrm{PuO}_{1} \cdot 10^{2}\right\rangle+0.15 \quad\left(\mathrm{IrO}_{2}\right)$

$\langle\mathrm{Ir}\rangle=\left\langle\mathrm{PuO}_{1 \cdot 65}\right\rangle+0.175\left(\mathrm{IrO}_{2}\right)$

$\langle$ Ir $\rangle=\left\langle\mathrm{PuO}_{1 \cdot 61}\right\rangle+0.195$ (1rO)

$\langle\mathrm{Ir}\rangle=\left\langle\mathrm{PuO}_{1} \cdot 50\right\rangle+0.25 \quad\left(\mathrm{IrO}_{2}\right)$
G

$\mathrm{kcal} / \mathrm{mole}$

$+\quad 1.95$

$+\quad 4.82$

$+\quad 7.68$

$+9.63$

$+14.54$

$+12.46$

$+24.38$

$+\quad 29.39$

$+34.40$

$+38.50$

$+60.80$

REACTIONS TO FORM ( $\mathrm{IrO}_{2}$ ) at $1500^{\circ \mathrm{K}}$

Reactions

$\left\langle\mathrm{PuO}_{2}\right\rangle+0.01$
$\left\langle\mathrm{PuO}_{2}\right\rangle+0.025$
$\left\langle\mathrm{PuO}_{2}\right\rangle+0.04$
$\left\langle\mathrm{PuO}_{2}\right\rangle+0.05$
$\left\langle\mathrm{PuO}_{2}\right\rangle+0.075$
$\left\langle\mathrm{PuO}_{2}\right\rangle+0.10$
$\left\langle\mathrm{PuO}_{2}\right\rangle+0.125$
$\left\langle\mathrm{PuO}_{2}\right\rangle+0.15$
$\left\langle\mathrm{PuO}_{2}\right\rangle+0.175$
$\left\langle\mathrm{PuO}_{2}\right\rangle+0.195$
$\left\langle\mathrm{PuO}_{2}\right\rangle+0.25$

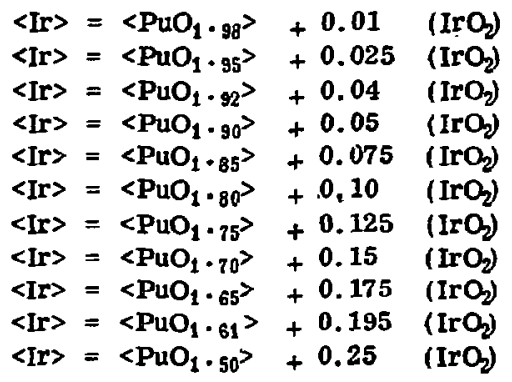

G

kcal/mole

$+\quad 1.28$
$+\quad 3.42$
$+\quad 5.66$
$+\quad 7.23$
$+\quad 11.30$
$+\quad 15.56$
$+\quad 20.03$
$+\quad 24.70$
$+\quad 29.41$
$+\quad 33.27$
$+\quad 43.81$


REACTIONS TO FORM ( $\mathrm{IrO}_{2}$ ) at $1600^{\circ \mathrm{K}}$

Reactions

$\left\langle\mathrm{PuO}_{2}\right\rangle+0.01$
$\left\langle\mathrm{PuO}_{2}\right\rangle+0.025$
$\left\langle\mathrm{PuO}_{2}\right\rangle+0.04$
$\left\langle\mathrm{PuO}_{2}\right\rangle+0.65$
$\left\langle\mathrm{PuO}_{2}\right\rangle+0.075$
$\left\langle\mathrm{PuO}_{2}\right\rangle+0.10$
$\left\langle\mathrm{PuO}_{2}\right\rangle+0.125$
$\left\langle\mathrm{PuO}_{2}\right\rangle+0.15$
$\left\langle\mathrm{PuO}_{2}\right\rangle+0.175$
$\left\langle\mathrm{PuO}_{2}\right\rangle+0.195$
$\left\langle\mathrm{PuO}_{2}\right\rangle+0.25$

$\langle$ Ir $\rangle=\left\langle\mathrm{PuO}_{1} \cdot 98+0.01 \quad\left(\mathrm{IrO}_{2}\right)\right.$

$\langle\mathrm{Ir}\rangle=\left\langle\mathrm{PuO}_{1 \cdot 95}\right\rangle+0.025\left(\mathrm{IrO}_{2}\right)$

$\langle\mathrm{Ir}\rangle=\left\langle\mathrm{PuO}_{1 \cdot 92}\right\rangle+0.04 \quad\left(\mathrm{IrO}_{2}\right)$

$\langle\mathrm{Ir}\rangle=\left\langle\mathrm{PuO}_{1} \cdot \mathrm{gO}\right\rangle+0.05 \quad\left(\mathrm{IrO}_{2}\right)$

$\langle\mathrm{lr}\rangle=\left\langle\mathrm{PuO}_{1 \cdot 85}\right\rangle+0.075\left(\mathrm{IrO}_{2}\right)$

$\langle\mathrm{Ir}\rangle=\left\langle\mathrm{PuO}_{1} \cdot 80^{2}\right\rangle+0,10 \quad\left(\mathrm{IrO}_{2}\right)$

$\langle\mathrm{Ir}\rangle=\left\langle\mathrm{PuO}_{1} \cdot 75\right\rangle+0.125\left(\mathrm{IrO}_{2}\right)$

$\left.\langle\mathrm{Ir}\rangle=\left\langle\mathrm{PuO}_{1} \cdot 7\right\rangle\right\rangle+0.15 \quad\left(\mathrm{IrO}_{2}\right)$

$\langle\mathrm{Ir}\rangle=\left\langle\mathrm{PuO}_{1} \cdot 65\right\rangle+0.175 \quad\left(\mathrm{IrO}_{\mathrm{j}} \mathrm{j}\right.$

$\langle\mathrm{Ir}\rangle=\left\langle\mathrm{PuO}_{1} \cdot 61\right\rangle+0.195\left(\mathrm{IrO}_{2}\right)$

$\langle\mathrm{Ir}\rangle=\left\langle\mathrm{PuO}_{1} \cdot 50\right\rangle+0.25 \quad\left(\mathrm{IrO}_{2}\right)$
$\Delta \mathbf{G}$

kcal/mole

$+\quad 1.14$
$+\quad 3.14$
$+\quad 5.25$
$+\quad 6.75$
$+\quad 10.65$
$+\quad 14.79$
$+\quad 19.16$
$+\quad 23.76$
$+\quad 28.42$
$+\quad 32.22$
$+\quad 42.64$

TABLE $\quad B-62$

REACTIONS TO FORM ( $\left.\mathrm{IrO}_{2}\right)$ at $17000_{\mathrm{K}}$

Reactions

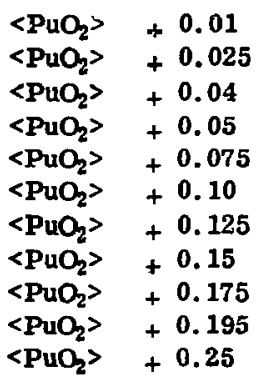

$\langle\mathrm{Ir}\rangle=\left\langle\mathrm{PuO}_{1 \cdot 98}\right\rangle+0.01 \quad\left(\mathrm{IrO}_{2}\right)$ $\langle\mathrm{Ir}\rangle=\left\langle\mathrm{PuO}_{1} \cdot 95\right\rangle+0.025\left(\mathrm{IrO}_{2}\right)$ $\langle\mathrm{Ir}\rangle=\left\langle\mathrm{PuO}_{1} \cdot \mathrm{gg}\right\rangle+0.04 \quad\left(\mathrm{IrO}_{2}\right)$ $\langle$ Ir $\rangle=\left\langle\mathrm{PuO}_{1} \cdot 90^{\rangle}+0.05 \quad\left(\mathrm{IrO}_{2}\right)\right.$ $\langle$ Ir $\rangle=\left\langle\mathrm{PuO}_{1} \cdot 85\right\rangle+0.075\left(\mathrm{IrO}_{2}\right)$ $\langle\mathrm{Ir}\rangle=\left\langle\mathrm{PuO}_{1} \cdot 80^{\prime}+.0,10 \quad\left(\operatorname{Ir} \mathrm{O}_{2}\right)\right.$ $\langle\mathrm{Ir}\rangle=\left\langle\mathrm{PuO}_{1} \cdot 75^{2}+0.125 \quad(\mathrm{IrO})\right.$ $\langle\mathrm{Ir}\rangle=\left\langle\mathrm{PuO}_{1} \cdot 70\right\rangle+0.15 \quad\left(\mathrm{IrO}_{2}\right)$ $\left\langle\mathrm{I}^{\circ}\right\rangle=\left\langle\mathrm{PuO}_{1} \cdot 65\right\rangle+0.175 \quad\left(\mathrm{IrO}_{2}\right)$ $\langle\mathrm{Ir}\rangle=\left\langle\mathrm{PuO}_{1} \cdot 61\right\rangle+0.195(\mathrm{IrO})$ $\langle\mathrm{Ir}\rangle=\left\langle\mathrm{PuO}_{1} \cdot 50\right\rangle+0.25 \quad\left(\mathrm{IrO}_{2}\right)$
$\Delta \mathbf{G}$

kcal/mole

$+\quad 1.01$

$+\quad 2.86$

$+\quad 4.84$

$+\quad 6.27$

$+\quad 10.00$

$+\quad 14.01$

$+\quad 18.29$

$+\quad 22.82$

$+\quad 27.42$

$+\quad 31.17$

$+41.48$ 
REACTIONS TO FORM (IrO, $)$ at $1800^{\circ}$

Reactions

$\Delta \mathbf{G}$

kcal/mole

$\left\langle\mathrm{PuO}_{2}\right\rangle+0.01$
$\left\langle\mathrm{PuO}_{2}\right\rangle+0.025$
$\left\langle\mathrm{PuO}_{2}\right\rangle+0.04$
$\left\langle\mathrm{PuO}_{2}\right\rangle+0.05$
$\left\langle\mathrm{PuO}_{2}\right\rangle+0.075$
$\left\langle\mathrm{PuO}_{2}\right\rangle+0.10$
$\left\langle\mathrm{PuO}_{2}\right\rangle+0.125$
$\left\langle\mathrm{PuO}_{2}\right\rangle+0.15$
$\left\langle\mathrm{PuO}_{2}\right\rangle+0.175$
$\left\langle\mathrm{PuO}_{2}\right\rangle+0.195$
$\left\langle\mathrm{PuO}_{2}\right\rangle+0.25$

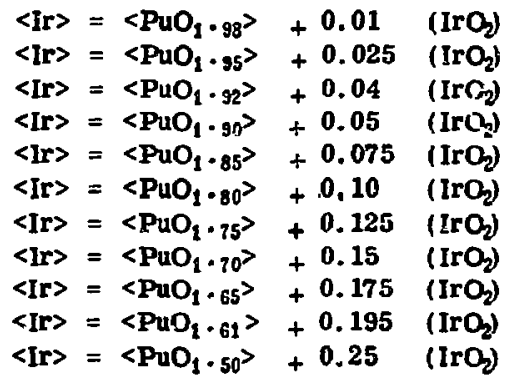

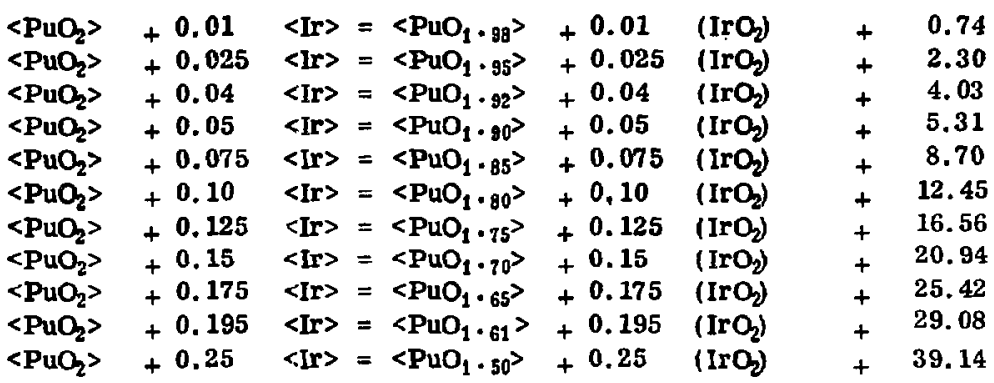


REACTIONS TO FORM $\left(1 \mathrm{IO}_{2}\right)$ at $20000 \mathrm{~K}$

Renctions

$\Delta^{G}$

keal/mole

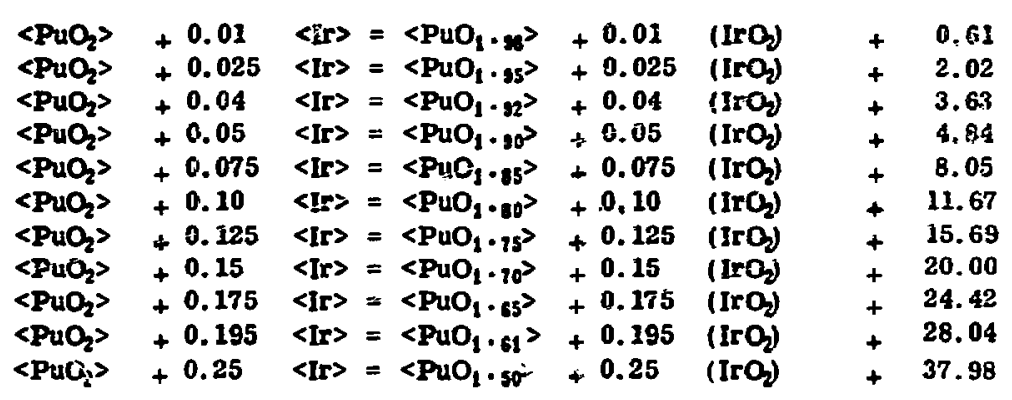

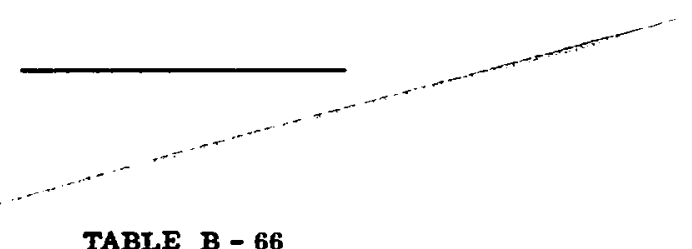

TABLE B-66

REACTIONS TO FORM (IrOz) at21000K

Regctions

$\Delta G$

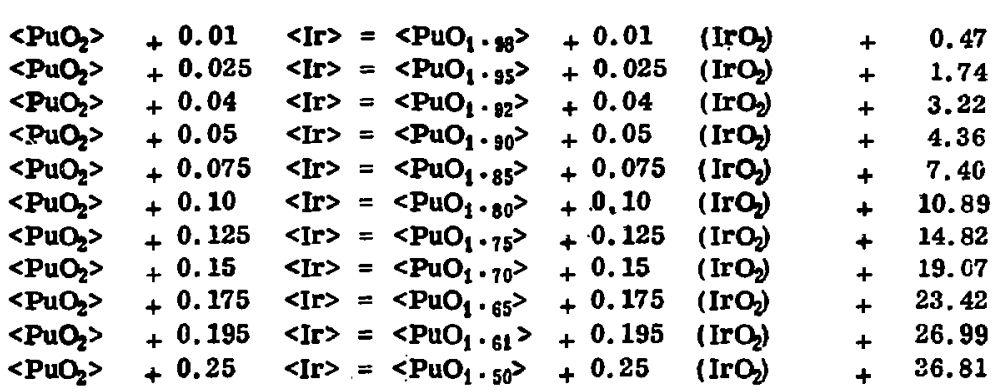




\section{REACTONS TO FORM (1RO, at2200'K}

Reactions

$\left\langle\mathrm{PuO}_{2}\right\rangle+0.01$
$\left\langle\mathrm{PuO}_{2}\right\rangle+0.025$
$\left\langle\mathrm{PuO}_{2}\right\rangle+0.04$
$\left\langle\mathrm{PuO}_{2}\right\rangle+0.05$
$\left\langle\mathrm{PuO}_{2}\right\rangle+0.075$
$\left\langle\mathrm{PuO}_{2}\right\rangle+0.10$
$\left\langle\mathrm{PuO}_{2}\right\rangle+0.125$
$\left\langle\mathrm{PuO}_{2}\right\rangle+0.15$
$\left\langle\mathrm{PuO}_{2}\right\rangle+0.175$
$\left\langle\mathrm{PuO}_{2}\right\rangle+0.195$
$\left\langle\mathrm{PuO}_{2}\right\rangle+0.25$

$\langle$ Ir $\rangle=\left\langle\mathrm{PuO}_{1} \cdot \mathrm{u}\right\rangle+0.01 \quad$ (1rO)

$\langle\mathrm{Ir}\rangle=\left\langle\mathrm{PuO}_{\mathrm{I}} \cdot \mathrm{as}^{\mathrm{S}}\right\rangle+0.025 \quad\left(\mathrm{IrO}_{2}\right)$

$\langle$ Ir $\rangle=\left\langle\right.$ PuO $\left._{1} \cdot g^{\prime}\right\rangle+0.04$ (IrO)

$\langle$ Ir $\rangle=\left\langle\mathrm{PuO}_{1} \cdot 90^{20}\right\rangle+0.05 \quad$ (IrO)

$\langle$ Ir $\rangle=\left\langle\mathrm{PuO}_{1-\mathrm{BS}}\right\rangle+0.075$ (IrO)

$\langle$ Ir $\rangle=\left\langle\mathrm{PuO}_{1}+\mathrm{RO}\right\rangle+0,10 \quad\left(\mathrm{irO}_{2}\right)$

$\langle$ Ir $\rangle=\left\langle P_{U} O_{t} \cdot 15\right\rangle+0.125$ (IrO)

$\langle\mathrm{Ir}\rangle=\left\langle\mathrm{PuO}_{1 \cdot 10}\right\rangle+0.15 \quad(\mathrm{IrO})$

$\langle\mathrm{Ir}\rangle=\left\langle\mathrm{PuO}_{\mathrm{I}} \cdot(\mathrm{ts}\rangle+0.275\right.$ (IrO)

$\langle\mathrm{Ir}\rangle=\left\langle\mathrm{PuO}_{1} \cdot \mathrm{BI}\right\rangle+0.195$ (IrO)

$\langle$ Ir $\rangle=\left\langle\mathrm{PuO}_{1} \cdot 5 \theta^{\circ}+0.25\right.$ (IrO)
A

kenlmole

$+\quad 0.34$

$+\quad 1.46$

$+\quad 2.82$

$+3.88$

$+\quad 6.75$

$+10.13$

$+13.25$

$+\quad 18.13$

$+22.33$

$+25.84$

$+35.64$

TABLE B - 68

REACTIONS TO FORM ( $\left.\mathrm{IrO}_{3}\right)$ at $1000 \mathrm{OK}$

Reactions

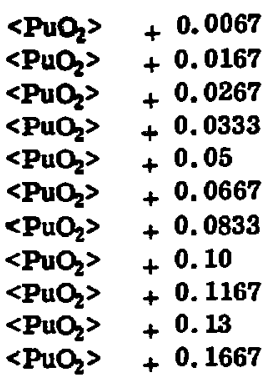

$\mathbf{G}$

kcal/mole

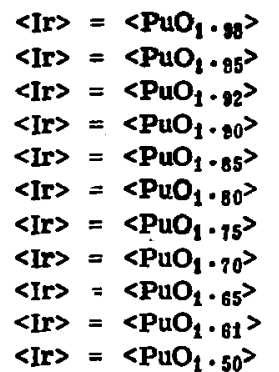

$0.0067\left(\mathrm{IrO}_{3}\right)$

1.60 +0.0167 (IrOs) $+0.0267\left(\right.$ IrO $\left._{3}\right)$ $+0.0333\left(\mathrm{IrO}_{3}\right)$ +0.05 (IrOj) $+0.0667\left(\mathrm{IrO}_{3}\right)$ +0.0833 (IrO) +0.10 (IrO) $+0.1167\left(\mathrm{IrO}_{3}\right)$ +0.13 (IrO) $+0.1667\left(\mathrm{IrO}_{5}\right)$
3.95
$+\quad 30$

+6.30
$+\quad 8.90$

6.90
$+\quad 7.90$

$+11.94$

15.99
$+\quad 20.04$

$+20.04$

$+24.19$

28.34
$+\quad 31.74$

$+\quad 31.74$
$+\quad 40.98$

$+\quad 40.98$ 
REACTIONS TO FORM (ItOy) at 2300 PK

Resations

\begin{tabular}{|c|c|}
\hline 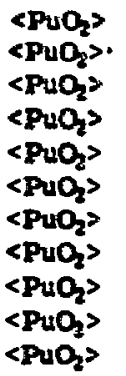 & $\begin{aligned}+ & 0.0067 \\
+ & 0.0267 \\
+ & 0.0267 \\
+ & 0.0333 \\
+ & 0.05 \\
+ & 0.0667 \\
+ & 0.0833 \\
+ & 0.19 \\
+ & 0.1167 \\
+ & 0.13 \\
+ & 0.21669\end{aligned}$ \\
\hline
\end{tabular}

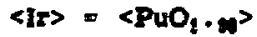

$\langle\mathrm{ir}\rangle=\left\langle\mathrm{PuO}_{\mathrm{g}} \cdot \mathrm{gs}_{\mathrm{s}}\right\rangle$

$\langle\mathrm{Ir}\rangle=\left\langle\mathrm{PuO}_{1} \cdot \mathrm{M2}\right\rangle$

$\langle$ Ir $\rangle=\left\langle\mathrm{PuO}_{1} \cdot 9{ }^{2}\right\rangle$

$\langle\mid r\rangle=\left\langle\mathrm{PuO}_{\mathrm{i}} \cdot \mathrm{At}\right\rangle$

$\langle\mathrm{IT}\rangle=\left\langle\mathrm{PuO}_{1} \cdot 10\right\rangle$

$\langle$ IT $\rangle=\left\langle\mathrm{PuO}_{1} \cdot 7 \mathrm{H}\right\rangle$

$\langle$ Ir $\rangle=\left\langle\right.$ PuO $\left._{1 \cdot 70}\right\rangle$

$\langle\mathrm{Ir}\rangle=\left\langle\mathrm{PuO}_{\mathrm{q}} \cdot \mathrm{CS}\right\rangle$

$\langle\mathrm{Ir}\rangle=\left\langle\mathrm{PuO}_{2} \cdot \mathrm{GI}_{2}\right\rangle$

$\langle 1 r\rangle=\left\langle\mathrm{PuO}_{1} \cdot \mathrm{sp}\right\rangle$
$\Delta \mathbf{G}$

kcal/mole

+0.0067 (IrO)

$+0.0167\left(15 O_{3}\right)$

+0.0267 (1roj)

+0.0333 \{[rO\}

+0.05 (irO

+0.0667 (IrO)

$+0.0833\left(\mathrm{IrO}_{\mathrm{S}}\right)$

+0.10 (IrO)

+0.1167 (IrO)

$+0.13\left(\mathrm{IrO}_{3}\right)$

+0.1667 (IrO)
1.23

3.19

4.76

6.62

10.24

13.98

17.85

21.87

$+25.92$

$+29.24$

$+38.30$

TABLE B - 70

REACTIONS TO FORM (IrO) at $1500 \mathrm{~K}$

Reactions

${ }_{A} \mathbf{G}$

kcal/mole

$\left\langle\mathrm{PuO}_{2}\right\rangle+0.0067$
$\left\langle\mathrm{PuO}_{2}\right\rangle+0.0167$
$\left\langle\mathrm{PuO}_{2}\right\rangle+0.0267$
$\left\langle\mathrm{PuO}_{2}\right\rangle+0.0333$
$\left\langle\mathrm{PuO}_{2}\right\rangle+0.05$
$\left\langle\mathrm{PuO}_{2}\right\rangle+0.0667$
$\left\langle\mathrm{PuO}_{2}\right\rangle+0.0833$
$\left\langle\mathrm{PuO}_{2}\right\rangle+0.10$
$\left\langle\mathrm{PuO}_{2}\right\rangle+0.1167$
$\left\langle\mathrm{PuO}_{2}\right\rangle+0.13$
$\left\langle\mathrm{PuO}_{2}\right\rangle+0.1667$

$\langle\mathrm{Ir}\rangle=\left\langle\mathrm{PuO}_{1} \cdot \mathrm{H}\right\rangle$

$+0.0067\left(\mathrm{IrO}_{3}\right)$

$\langle I r\rangle=\left\langle\mathrm{PuO}_{1} \cdot 95\right\rangle+0.0167\left(\mathrm{Ir} \mathrm{O}_{j}\right)$

$\langle$ Ir $\rangle=\left\langle\mathrm{PuO}_{1} \cdot 12\right\rangle+0.0267($ IrO $)$

$\langle$ Ir $\rangle=\left\langle\mathrm{PuO}_{1} \cdot 90\right\rangle+0.0333\left(\mathrm{IrO}_{3}\right)$

$\langle\mathrm{Ir}\rangle=\left\langle\mathrm{PuO}_{1 \cdot 85}\right\rangle+0.05 \quad\left(\mathrm{IrO}_{5}\right)$

$\langle\mathrm{Ir}\rangle=\left\langle\mathrm{PuO}_{1} \cdot \mathrm{BO}\right\rangle+0.0667\left(\mathrm{IrO}_{\mathrm{g}}\right)$

$\langle\mathrm{Ir}\rangle=\left\langle\mathrm{PuO}_{1} \cdot 75\right\rangle+0.0833\left(\mathrm{IrO}_{3}\right)$

$\langle$ Ir $\rangle=\left\langle\mathrm{PuO}_{1} \cdot 70\right\rangle+0.10\left(\mathrm{IrO}_{3}\right)$

$\langle$ Ir $\rangle=\left\langle\mathrm{PuO}_{1} \cdot 65\right\rangle+0.1167\left(\mathrm{ILO}_{3}\right)$

$\langle\mathrm{Ir}\rangle=\left\langle\mathrm{PuO}_{1 \cdot 61}\right\rangle+0.13 \quad\left(\mathrm{IrO}_{3}\right)$

$\langle\mathrm{Ir}\rangle=\left\langle\mathrm{PuO}_{1} \cdot 50\right\rangle$

+0.13 (IrO)
+0.1667 (IrO) $+\quad 0.99$

$+\quad 4.49$

$+5.77$

$+12.65$

$+16.38$

$+20.32$

$+24.31$

$+27.5 \%$

+36.52
$+\quad 37$
+2.69
$+\quad 2.99$

$+\quad 9.11$ 
REACTIONS TO FORM ( $\left(\mathrm{IrO}_{3}\right)$ at $1600^{\circ} \mathrm{K}$

Reactions

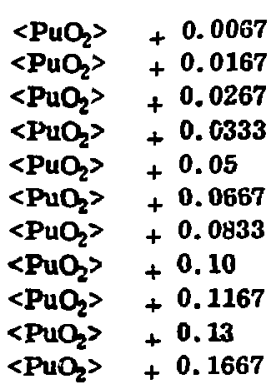

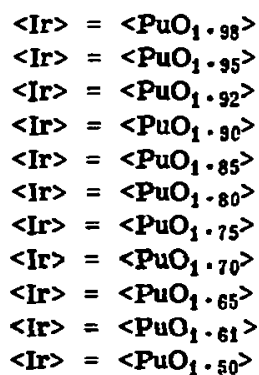

$+0.0067\left(\mathrm{IrO}_{3}\right)$ $+0.0167\left(\mathrm{IrO}_{3}\right)$

$+0.0267($ IrOs)

$+0.0333\left(\mathrm{IrO}_{3}\right)$

$+0.05\left(\mathrm{IrO}_{3}\right)$

$+0.0667\left(\mathrm{IrO}_{3}\right)$

$+0.0833\left(\mathrm{IrO}_{3}\right)$

$+0.10\left(\mathrm{IrO}_{3}\right)$

$+0.1167\left(\mathrm{IrO}_{3}\right)$

+0.13 (IrO)

+0.1667 (IrO)
$\Delta \mathbf{G}$

kcal/mole

\begin{tabular}{r}
0.86 \\
$+\quad 2.43$ \\
4.13 \\
+5.35 \\
\hline 11.98 \\
15.65 \\
19.54 \\
23.50 \\
26.74 \\
35.62
\end{tabular}

REACTIONS TO FORM (IrO $)^{\text {at } 17000}$

Reactions

$\left\langle\mathrm{PuO}_{2}\right\rangle+0.0067$
$\left\langle\mathrm{PuO}_{2}\right\rangle+0.0167$
$\left\langle\mathrm{PuO}_{2}\right\rangle+0.0267$
$\left\langle\mathrm{PuO}_{2}\right\rangle+0.0333$
$\left\langle\mathrm{PuO}_{2}\right\rangle+0.05$
$\left\langle\mathrm{PuO}_{2}\right\rangle+0.0667$
$\left\langle\mathrm{PuO}_{2}\right\rangle+0.0833$
$\left\langle\mathrm{PuO}_{2}\right\rangle+0.10$
$\left\langle\mathrm{PuO}_{2}\right\rangle+0.1167$
$\left\langle\mathrm{PuO}_{2}\right\rangle+0.13$
$\left\langle\mathrm{PuO}_{2}\right\rangle+0.1667$

$\langle\mathrm{Ir}\rangle=\left\langle\mathrm{PuO}_{1} \cdot 98\right\rangle+0.0067\left(\mathrm{IrO}_{3}\right)$

$\langle\mathrm{Ir}\rangle=\left\langle\mathrm{PuO}_{1} \cdot 95\right\rangle+0.0167\left(\mathrm{IrO}_{3}\right)$

$\langle\mathrm{Ir}\rangle=\left\langle\mathrm{PuO}_{1} \cdot 92\right\rangle+0.0267\left(\mathrm{IrO}_{3}\right)$

$\langle\mathrm{Ir}\rangle=\left\langle\mathrm{PuO}_{1} \cdot 90\right\rangle+0.0333\left(\mathrm{IrO}_{3}\right)$

$\langle\mathrm{Ir}\rangle=\left\langle\mathrm{PuO}_{1} \cdot 85\right\rangle+0.05 \quad\left(\mathrm{IrO}_{3}\right)$

$\langle\mathrm{Ir}\rangle=\left\langle\mathrm{PuO}_{1 \cdot 80}\right\rangle+0.0667\left(\mathrm{IrO}_{3}\right)$

$\langle$ Ir $\rangle=\left\langle\mathrm{PuO}_{1} \cdot 75\right\rangle+0.0833\left(\mathrm{IrO}_{3}\right)$

$\langle\mathrm{Ir}\rangle=\left\langle\mathrm{PuO}_{1} \cdot 70\right\rangle+0.10\left(\mathrm{IrO}_{3}\right)$

$\langle\mathrm{Ir}\rangle=\left\langle\mathrm{PuO}_{1} \cdot 65\right\rangle+0.1167\left(\mathrm{IrO}_{3}\right)$

$\langle\mathrm{Ir}\rangle=\left\langle\mathrm{PuO}_{1} \cdot \mathrm{Gl}_{1}\right\rangle+0.13\left(\mathrm{IrO}_{3}\right)$

$\langle\mathrm{Ir}\rangle=\left\langle\mathrm{PuO}_{1} \cdot 50^{2}+0.1667\left(\right.\right.$ IrO $\left._{3}\right)$
$\Delta \mathbf{G}$

kcal/mole

$+\quad 0.74$
$+\quad 2.18$
$+\quad 3.76$
$+\quad 4.92$
$+\quad 7.98$
$+\quad 11.31$
$+\quad 14.92$
$+\quad 18.77$
$+\quad 22.69$
$+\quad 25.91$
$+\quad 34.73$


REACTIONS TO FORM ( $\operatorname{IrO}_{3}$ ) at $1800^{\circ} \mathrm{K}$

Reactions

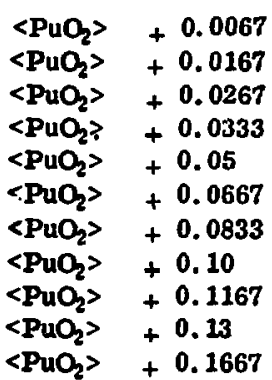

$\langle\mathrm{Ir}\rangle=\left\langle\mathrm{PuO}_{1} \cdot 98\right\rangle$ $\langle\mathrm{Ir}\rangle=\left\langle\mathrm{PuO}_{1} \cdot 95\right\rangle$ $\langle\mathrm{Ir}\rangle=\left\langle\mathrm{PuO}_{1} \cdot \mathrm{9P}_{2}\right\rangle$ $\langle\mathrm{Ir}\rangle=\left\langle\mathrm{PuO}_{1} \cdot 90^{\rangle}\right\rangle$ $\langle\mathrm{Ir}\rangle=\left\langle\mathrm{PuO}_{1} \cdot 85\right\rangle$ $\langle$ Ir $\rangle=\left\langle\mathrm{PuO}_{1} \cdot 80^{2}\right\rangle$ $\langle$ Ir $\rangle=\left\langle\mathrm{PuO}_{1} \cdot 75\right\rangle$ $\langle$ Ir $\rangle=\left\langle\mathrm{PuO}_{1} \cdot 10\right\rangle$ $\langle$ Ir $\rangle=\left\langle\mathrm{PuO}_{1} \cdot 65\right\rangle$ $\langle$ Ir $\rangle=\left\langle\mathrm{PuO}_{1} \cdot 61\right\rangle$ $\langle$ Ir $\rangle=\left\langle\mathrm{PuO}_{1} \cdot 50\right\rangle$
$+0.0067\left(\mathrm{IrO}_{3}\right)$ $+0.0167\left(\mathrm{IrO}_{3}\right)$ $+0.0267\left(\mathrm{IrO}_{3}\right)$ $+0.0333\left(\mathrm{IrO}_{3}\right)$ $+0.05 \quad\left(\mathrm{IrO}_{3}\right)$ +0.0667 (IrOb) $+0.0833\left(\mathrm{IrO}_{3}\right)$ +0.10 ( IrO $\left._{3}\right)$ $+0.1167\left(\mathrm{IrO}_{3}\right)$ $+0.13\left(\mathrm{IrO}_{3}\right)$ $+0.1667($ IrOj)
$\Delta^{G}$

\section{$\mathrm{kcal} / \mathrm{mole}$}

$+\quad 0.62$

$+\quad 1.98$

$+\quad 3.40$

$+\quad 4.50$

$+\quad 7.41$

$+\quad 10.64$

$+\quad 14.19$

$+18.00$

$+21.89$

$+25.08$

+
$+\quad 33.84$

TABLE B -74

REACTIONS TO FORM $\left(\mathrm{IrO}_{3}\right)$ at $1900^{\circ} \mathrm{K}$

Reactions

$\left\langle\mathrm{PuO}_{2}\right\rangle+0.0067$
$\left\langle\mathrm{PuO}_{2}\right\rangle+0.0167$
$\left\langle\mathrm{PuO}_{2}\right\rangle+0.0267$
$\left\langle\mathrm{PuO}_{2}\right\rangle+0.0333$
$\left\langle\mathrm{PuO}_{2}\right\rangle+0.05$
$\left\langle\mathrm{PuO}_{2}\right\rangle+0.0667$
$\left\langle\mathrm{PuO}_{2}\right\rangle+0.0833$
$\left\langle\mathrm{PuO}_{2}\right\rangle+0.10$
$\left\langle\mathrm{PuO}_{2}\right\rangle+0.1167$
$\left\langle\mathrm{PuO}_{2}\right\rangle+0.13$
$\left\langle\mathrm{PuC}_{2}\right\rangle+0.1667$

$\langle\mathrm{Ir}\rangle=\left\langle\mathrm{PuO}_{1} \cdot{ }_{\mathrm{BB}}\right\rangle+0.0067\left(\mathrm{I} \cdot \mathrm{O}_{3}\right)$ $\langle\mathrm{Ir}\rangle=\left\langle\mathrm{PuO}_{1} \cdot 9 \mathrm{P}^{2}\right\rangle+0.0167\left(\mathrm{IrO}_{3}\right)$ $\langle\mathrm{Ir}\rangle=\left\langle\mathrm{PuO}_{1} \cdot \mathrm{g2}\right\rangle+0.0267\left(\mathrm{IrO}_{3}\right)$ $\langle\mathrm{Ir}\rangle=\left\langle\mathrm{PuO}_{1} \cdot 90\right\rangle+0.0333\left(\mathrm{IrO}_{3}\right)$ $\langle$ Ir $\rangle=\left\langle\mathrm{PuO}_{1 \cdot 85}\right\rangle+0.05 \quad\left(\right.$ Ir $\left.\Omega_{\mathrm{j}}\right)$ $\langle$ Ir $\rangle=\left\langle\mathrm{PuO}_{1 \cdot B 0}\right\rangle+0.0667\left(\right.$ IrO $\left._{3}\right)$ $\langle\mathrm{Ir}\rangle=\left\langle\mathrm{PuO}_{1 \cdot 75}\right\rangle+0.0833\left(\mathrm{IrO}_{3}\right)$ $\langle\mathrm{Ir}\rangle=\left\langle\mathrm{PuO}_{1} \cdot 70\right\rangle+0.10\left(\mathrm{IrO}_{3}\right)$ $\langle$ Ir $\rangle=\left\langle\right.$ PuO $\left._{1 \cdot 65}\right\rangle+0.1167\left(\mathrm{IrO}_{3}\right)$ $\langle\mathrm{Ir}\rangle=\left\langle\mathrm{PuO}_{1.61}\right\rangle+0.13 \quad\left(\mathrm{IrO}_{3}\right)$ $\langle$ Ir $\rangle=\left\langle\mathrm{PuO}_{1} \cdot 50\right\rangle+0.1667\left(\mathrm{IrO}_{3}\right)$
$\mathbf{G}^{\mathbf{G}}$

kcal/mole

$+\quad 0.49$
$+\quad 1.68$
$+\quad 3.04$
$+\quad 4.07$
$+\quad 6.84$
$+\quad 9.97$
$+\quad 13.46$
$+\quad 17.22$
$+\quad 21.08$
$+\quad 24.25$
$+\quad 32.94$


REACTIONS TO FORM (IrO $\mathrm{O}_{3}$ at $2000^{\circ} \mathrm{K}$

\section{Reactions}

$\left\langle\mathrm{PuO}_{2}\right\rangle+0.0067$
$\left\langle\mathrm{PuO}_{2}\right\rangle+0.0167$
$\left\langle\mathrm{PuO}_{2}\right\rangle+0.0267$
$\left\langle\mathrm{PuO}_{2}\right\rangle+0.0333$
$\left\langle\mathrm{PuO}_{2}\right\rangle+0.05$
$\left\langle\mathrm{PuO}_{2}\right\rangle+0.0667$
$\left\langle\mathrm{PuO}_{2}\right\rangle+0.0833$
$\left\langle\mathrm{PuO}_{2}\right\rangle+0.10$
$\left\langle\mathrm{PuO}_{2}\right\rangle+0.1167$
$\left\langle\mathrm{PuO}_{2}\right\rangle+0.13$
$\left\langle\mathrm{PuO}_{2}\right\rangle+0.1667$

$\langle$ Ir $\rangle=\left\langle\mathrm{PuO}_{1} \cdot \mathrm{se}\right\rangle$

$\langle\mathrm{Ir}\rangle=\left\langle\mathrm{PuO}_{1} \cdot \mathrm{es}^{\rangle}\right\rangle$

$\langle\mathrm{Ir}\rangle=\left\langle\mathrm{PuO}_{1} \cdot \mathrm{nI}\right\rangle$

$\langle$ Ir $\rangle=\left\langle\mathrm{PuO}_{1} \cdot 90\right\rangle$

$\langle$ Ir $\rangle=\left\langle\mathrm{PuO}_{1} \cdot 85\right\rangle$

$\langle\mathrm{Ir}\rangle=\left\langle\mathrm{PuO}_{1} \cdot \mathrm{B0}\right\rangle$

$\langle$ Ir $\left.\rangle=\left\langle\mathrm{PuO}_{1} \cdot 7\right\rangle^{-17}\right\rangle$

$\langle$ Ir $\rangle=\left\langle\mathrm{PuO}_{1} \cdot 10\right\rangle$

$\langle$ Ir $\rangle=\left\langle\mathrm{PuO}_{1} \cdot 65\right\rangle$

$\langle\mathrm{Ir}\rangle=\left\langle\mathrm{PuO}_{1} \cdot \mathrm{Gl}_{1}\right\rangle$

$\langle\mathrm{Ir}\rangle=\left\langle\mathrm{PuO}_{1} \cdot \mathrm{st}^{\mathrm{si}}\right\rangle$
$\Delta \mathbf{G}$

kcal/mole

$+0.0067\left(\mathrm{IrO}_{3}\right)$

+0.0167 (IrO)

+0.0267 (IrO)

+0.0333 (IrO)

+0.05 (IrO)

$+0.0667\left(\mathrm{IrO}_{3}\right)$

$+0.0833\left(\mathrm{IrO}_{3}\right)$

$+0.10 \quad\left(\mathrm{IrO}_{3}\right)$

$+0.1167\left(\mathrm{IrO}_{3}\right)$

+0.13 (IrO)

+0.1667 (IrOj)
0.37

$+\quad 1.42$

$+2.68$

$+3.65$

$+\quad 6.27$

$+\quad 9.30$

$+12.72$

$+16.45$

$+20.27$

$+23.41$

$+29.92$

REACTIONS TO FORM (IrO) at $2100^{\circ} \mathrm{K}$

Resations

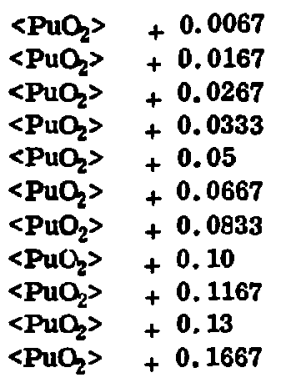

G

kcal/mole

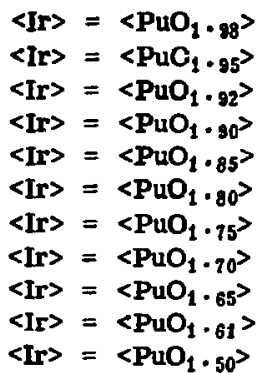

+0.0067 (IrO) $+0.0167\left(\mathrm{IrO}_{3}\right)$

$+0.0267\left(\mathrm{IrO}_{3}\right)$

$+0.0333\left(\mathrm{IrO}_{3}\right)$

+0.05 (IrO)

$+0.0667\left(\mathrm{IrO}_{3}\right)$

$+0.0833\left(\mathrm{IrO}_{3}\right)$

$+0.10\left(\mathrm{IrO}_{3}\right)$

$+0.1167\left(\mathrm{IrO}_{3}\right)$

$+0.13\left(\mathrm{IrO}_{3}\right)$

$+0.1667\left(\mathrm{IrO}_{3}\right)$
0.25

$+\quad 1.17$
$+\quad 1.32$

$+\quad 2.32$

$+3.22$

$+5.71$

$+8.63$

+11.99
$+\quad 15.68$

$+19.47$

+22.58
$+\quad 28.94$

$+28.94$ $+\quad 15.68$ 
REACTIONS TO FORM ( $\mathrm{IrO}_{3}$ ) at $2200^{\circ} \mathrm{K}$

Reactions

$\left\langle\mathrm{PuO}_{2}\right\rangle+0.0067$
$\left\langle\mathrm{PuO}_{2}\right\rangle+0.0167$
$\left\langle\mathrm{PuO}_{2}\right\rangle+0.0267$
$\left\langle\mathrm{PuO}_{2}\right\rangle+0.0333$
$\left\langle\mathrm{PuO}_{2}\right\rangle+0.05$
$\left\langle\mathrm{PuO}_{2}\right\rangle+0.0667$
$\left\langle\mathrm{PuO}_{2}\right\rangle+0.0833$
$\left\langle\mathrm{PuO}_{2}\right\rangle+0.10$
$\left\langle\mathrm{PuO}_{2}\right\rangle+0.1167$
$\left\langle\mathrm{PuO}_{2}\right\rangle+0.13$
$\left\langle\mathrm{PuO}_{2}\right\rangle+0.1667$

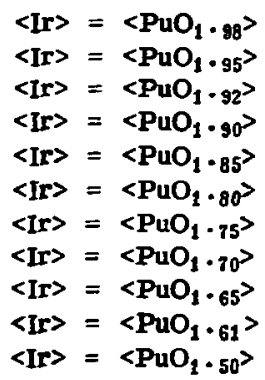

\section{TABLE $\quad$ B - 78}

TEMPERA TURES AT WHICE EQUILIBRIUM VALUES BECOME NEGA TIVE FOR THE REDUCTION OF $<\mathrm{PuO}_{2}>$ TO SPECIFIC $<\mathrm{PuO}_{2-\mathrm{x}}>$ COMPOSITIONS

\section{Reaction}
1. $\left\langle\mathrm{PuO}_{2}\right\rangle+\mathrm{x}\langle\mathrm{C}\rangle=\left\langle\mathrm{PuO}_{2-\mathrm{x}}\right\rangle+\mathrm{x}(\mathrm{CO})$
2. $\left\langle\mathrm{PuO}_{2}\right\rangle+\mathrm{x}(\mathrm{CO})=\left\langle\mathrm{PuO}_{2-\mathrm{x}}\right\rangle+\mathrm{x}\left(\mathrm{CO}_{2}\right)$
3. $\left\langle\mathrm{PuO}_{2}\right\rangle+\mathrm{x}\left(\mathrm{H}_{2}\right)=\left\langle\mathrm{PuO}_{2}-\mathrm{x}\right\rangle+\mathrm{x}\left(\mathrm{H}_{2} \mathrm{O}\right)$

\begin{tabular}{|c|c|c|c|}
\hline \multirow[b]{2}{*}{$\left.\leq \mathrm{PuO}_{2}=\mathrm{x}\right\rangle$} & \multicolumn{3}{|c|}{ Temperature, ${ }^{\circ} \mathrm{C}(\dot{\mp} 20)$} \\
\hline & Reaction 1 & Reaction 2 & Reaction 3 \\
\hline$\left\langle\mathrm{PuO}_{1} \cdot{ }_{98}\right\rangle$ & 1047 & 1370 & 1290 \\
\hline$\left\langle\mathrm{PuO}_{1} \cdot 95\right\rangle$ & 1077 & 1540 & 1420 \\
\hline$\left\langle\mathrm{PuO}_{1} \cdot \vartheta_{92}\right\rangle$ & 1100 & 1675 & 1515 \\
\hline$\left\langle\mathrm{PuO}_{1 \cdot 90}\right\rangle$ & 1120 & 1790 & 1590 \\
\hline$\left\langle\mathrm{PuO}_{1} \cdot \mathrm{Br}_{5}\right\rangle$ & 1160 & & 1760 \\
\hline$\left\langle\mathrm{PuO}_{1} \cdot 80\right\rangle$ & 1195 & & 1970 \\
\hline$\left\langle\mathrm{PuO}_{1} \cdot 75\right\rangle$ & 1240 & & \\
\hline$\left\langle\mathrm{PuO}_{1} \cdot 70^{\rangle}\right.$ & 1282 & & \\
\hline$\left\langle\mathrm{PuO}_{1} \cdot 65\right\rangle$ & 1322 & & \\
\hline$\left\langle\mathrm{PuO}_{1} \cdot 61\right\rangle$ & 1357 & & \\
\hline$\left\langle\mathrm{PuO}_{1} \cdot 50\right\rangle$ & 1420 & & \\
\hline
\end{tabular}


APPENDIX C

CALCULATIONS PERTAINING TO FSA SYSTEMS

TABLE C-1

DIMENSIONS OF 100 WA TT SPHERE AS A FUNCTION OF TEMPERA TURE

\begin{tabular}{|c|c|c|c|}
\hline Temp., ${ }^{\circ} \mathrm{C}$ & Diam, in. & Volume, $\mathrm{cm}^{3}$ & $\begin{array}{c}\text { Surface } \\
\text { Area, } \mathrm{cm}^{2} \\
\end{array}$ \\
\hline 20 & 1.465 & 26.98 & 43.50 \\
\hline 727 & 1.475 & 27.54 & 44.10 \\
\hline 1027 & 1.481 & 27.85 & 44.46 \\
\hline 1127 & 1.482 & 27.95 & 44.52 \\
\hline 1227 & 1.484 & 28.06 & 44.64 \\
\hline 1327 & 1.486 & 28.16 & 44.76 \\
\hline 1427 & 1.488 & 28.26 & 44.88 \\
\hline 1527 & 1.490 & 28.36 & 45.00 \\
\hline 1627 & 1.491 & 28.44 & 45.06 \\
\hline 1727 & 1.492 & 28.51 & 45.12 \\
\hline 1827 & 1.493 & 28.56 & 45.18 \\
\hline 1927 & 1.493 & 28.58 & 45.18 \\
\hline
\end{tabular}


TABLE C-2

\section{MAXIMUM GENERATION RATE OF IMPURTANT GASEOUS SPECIES DUE TO FUEL DISSOCIA TION $\mathrm{g} / \mathrm{cm}^{2} \mathrm{sec}$}

\begin{tabular}{|c|c|c|c|c|}
\hline Temp. ${ }^{\circ} \mathrm{K}$ & $\left(\mathrm{O}_{2}\right)$ & $\left(\mathrm{PuO}_{2}\right)$ & $\left(\mathrm{IrO}_{3}\right)$ & $\left(\mathrm{IrO}_{2}\right)$ \\
\hline 1600 & $7.5 \times 10^{-8}$ & $3.1 \times 10^{-10}$ & $2.8 \times 10^{-14}$ & $3.3 \times 10^{-13}$ \\
\hline 1700 & $1.5 \times 10^{-6}$ & $3.7 \times 10^{-9}$ & $9.0 \times 10^{-11}$ & $1.7 \times 10^{-10}$ \\
\hline 1800 & $1.7 \times 10^{-3}$ & $3.4 \times 10^{-8}$ & $1.1 \times 10^{-7}$ & $4.1 \times 10^{-8}$ \\
\hline 2000 & 4.9 & $1.6 \times 10^{-6}$ & 0.02 & $4.6 \times 10^{-4}$ \\
\hline 2100 & 148 & $7.3 \times 10^{-6}$ & 3.63 & $2.5 \times 10^{-2}$ \\
\hline 2200 & 3317 & 3. $1 \times 10^{-5}$ & 21.2 & 0.95 \\
\hline
\end{tabular}

Calculations based on fuel being $<\mathrm{PuO}_{2} \cdot 0$. Gaseous $\mathrm{Ir}-\mathrm{O}$ species are based on oxygen from fuel only, no impurity effects are considered. 
TABLE C-3

MAXTMUM EFFUSION RATES THROUGH FSA VENTS

DUE TO DISSOCLATION OF FUEL

\begin{tabular}{|c|c|c|c|c|}
\hline \multirow{2}{*}{ Temp. ${ }^{\circ} \mathrm{K}$} & & & & \multirow[b]{2}{*}{$\left(\mathrm{IrO}_{2}\right)$} \\
\hline & $\left(O_{2}\right)$ & $(\mathrm{PuO})$ & $\left(\mathrm{IrO}_{3}\right)$ & \\
\hline 1600 & $1.3 \times 10^{-5}$ & $5.3 \times 10^{-8}$ & $4.7 \times 10^{-12}$ & $5.7 \times 10^{-11}$ \\
\hline 1700 & $2.6 \times 10^{-3}$ & $6.3 \times 10^{-7}$ & $1.5 \times 10^{-8}$ & $2.7 \times 10^{-8}$ \\
\hline \multirow[t]{2}{*}{1800} & 0.29 & $6.6 \times 10^{-6}$ & $1.9 \times 10^{-5}$ & $6.9 \times 10^{-6}$ \\
\hline & \multicolumn{3}{|c|}{$\mathrm{g} / 5 \mathrm{~min}$} & \\
\hline 2000 & $\left(O_{2}\right)$ & $\left(\mathrm{PuO}_{2}\right)$ & $\left(\mathrm{IrO}_{3}\right)$ & $\left(\mathrm{IrO}_{2}\right)$ \\
\hline 2000 & $7.8 \times 10^{-3}$ & $2.6 \times 10^{-9}$ & $3.2 \times 10^{-5}$ & $7.5 \times 10^{-7}$ \\
\hline 2100 & 0.24 & $1.2 \times 10^{-8}$ & $5.8 \times 10^{-3}$ & $4.0 \times 10^{-5}$ \\
\hline 2200 & 5.4 & $5.0 \times 10^{-8}$ & 0.03 & $1.5 \times 10^{-3}$ \\
\hline
\end{tabular}

a. Calculations based on $\left\langle\mathrm{PuO}_{2} \cdot 0\right\rangle$ fuel. Gaseous $\mathrm{Ir}-\mathrm{O}$ species are due only to oxygen from fuel. No impurity effects are considered.

b. The values were calculated assuming two vents, 0.002 in. diam. If vent covers are added, the calculated values would decrease. 


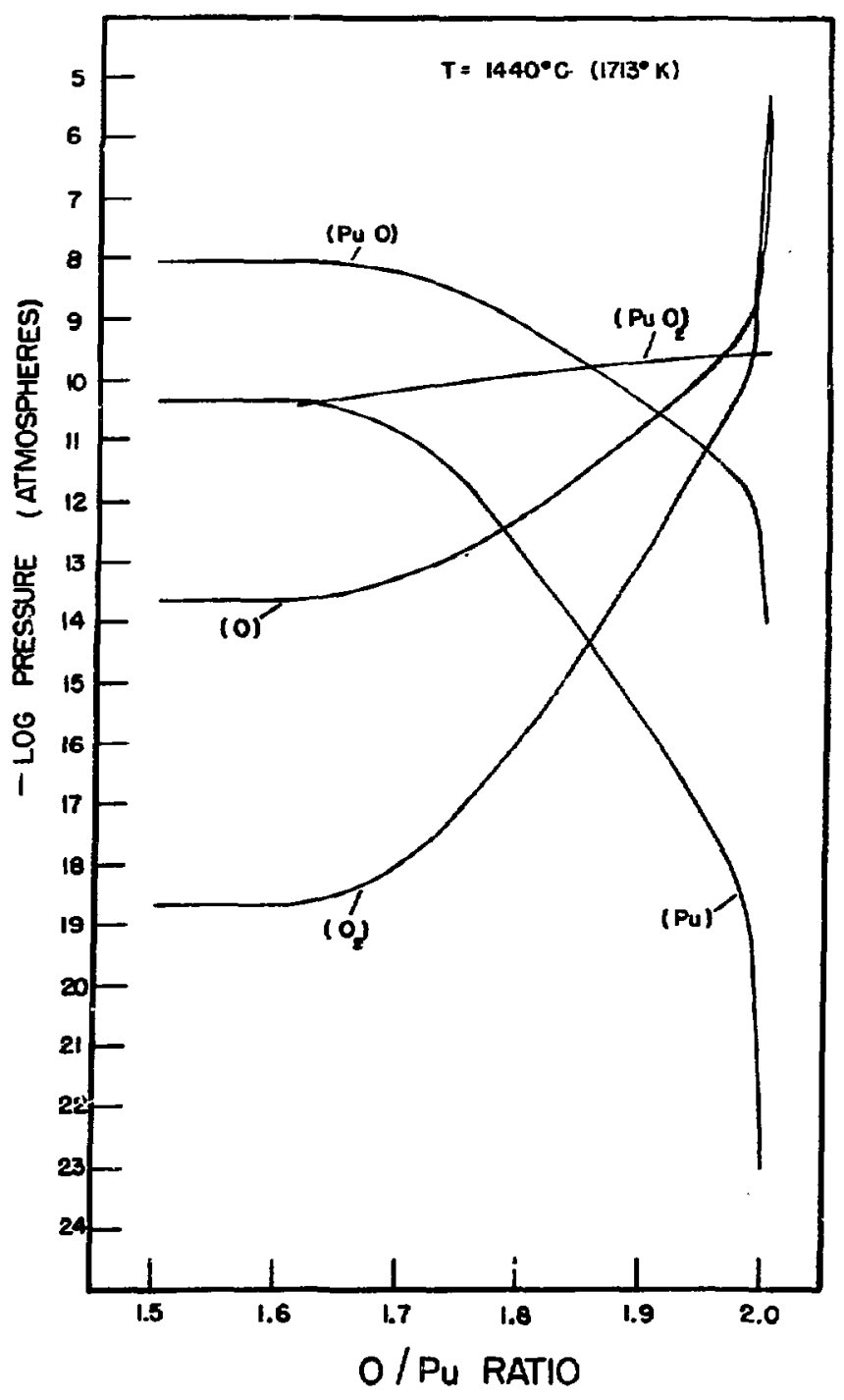

Fig. I Galculoted Partich Pressures of $1440^{\circ} \mathrm{C}$ 
- LOG PRESSLRE (ATMOSPHERES)

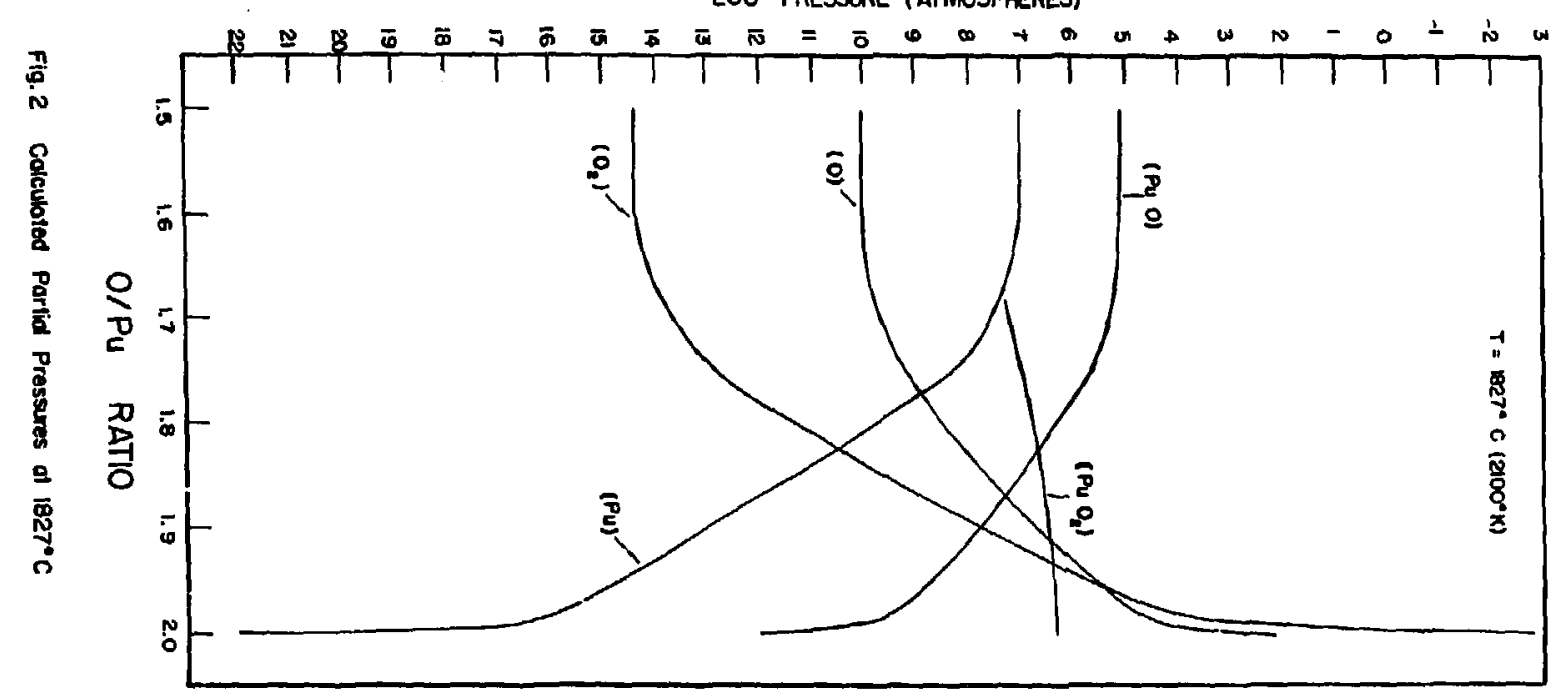




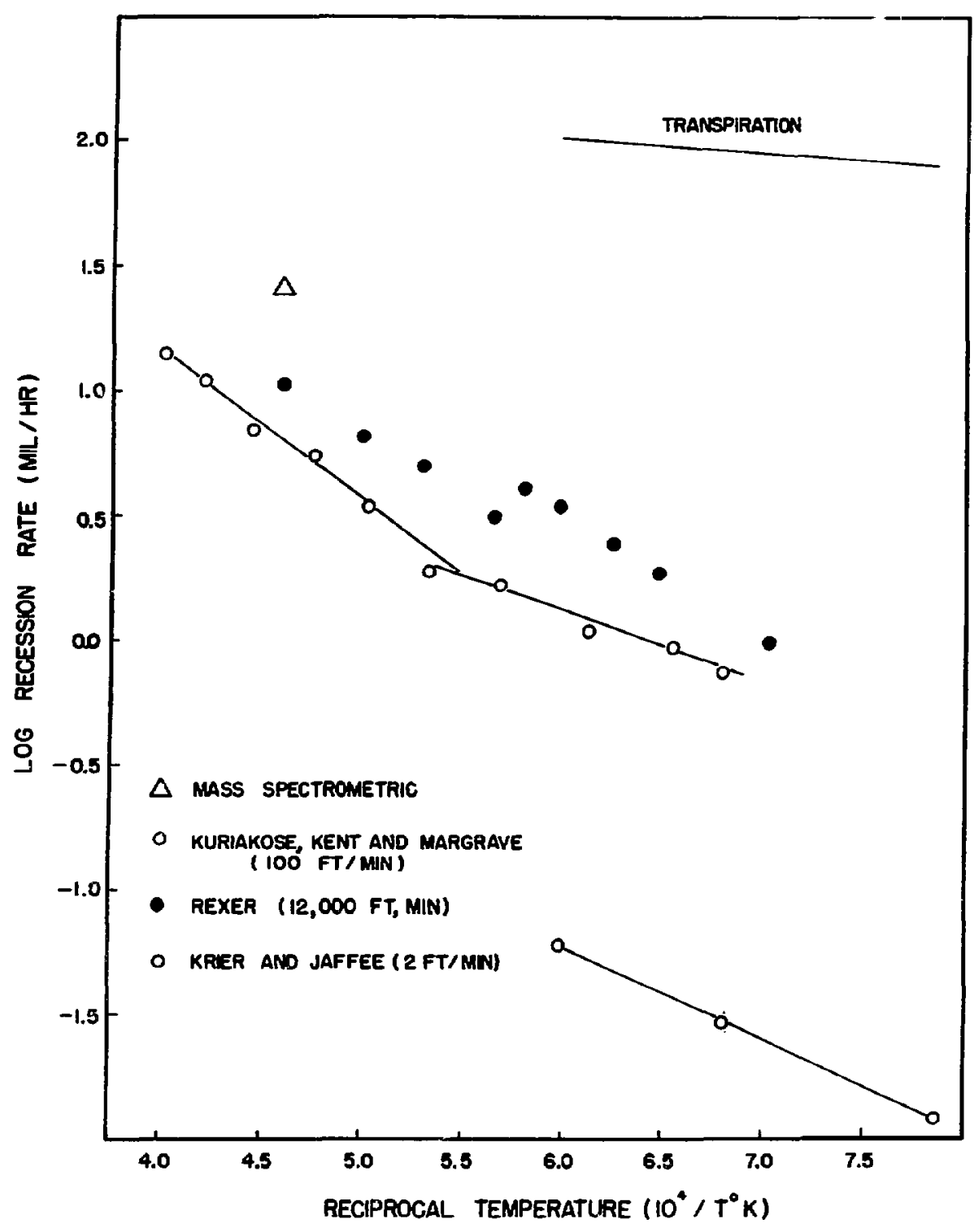

Fig.3 Recession Rate With 0.2 Atm Oxygen Pressure 


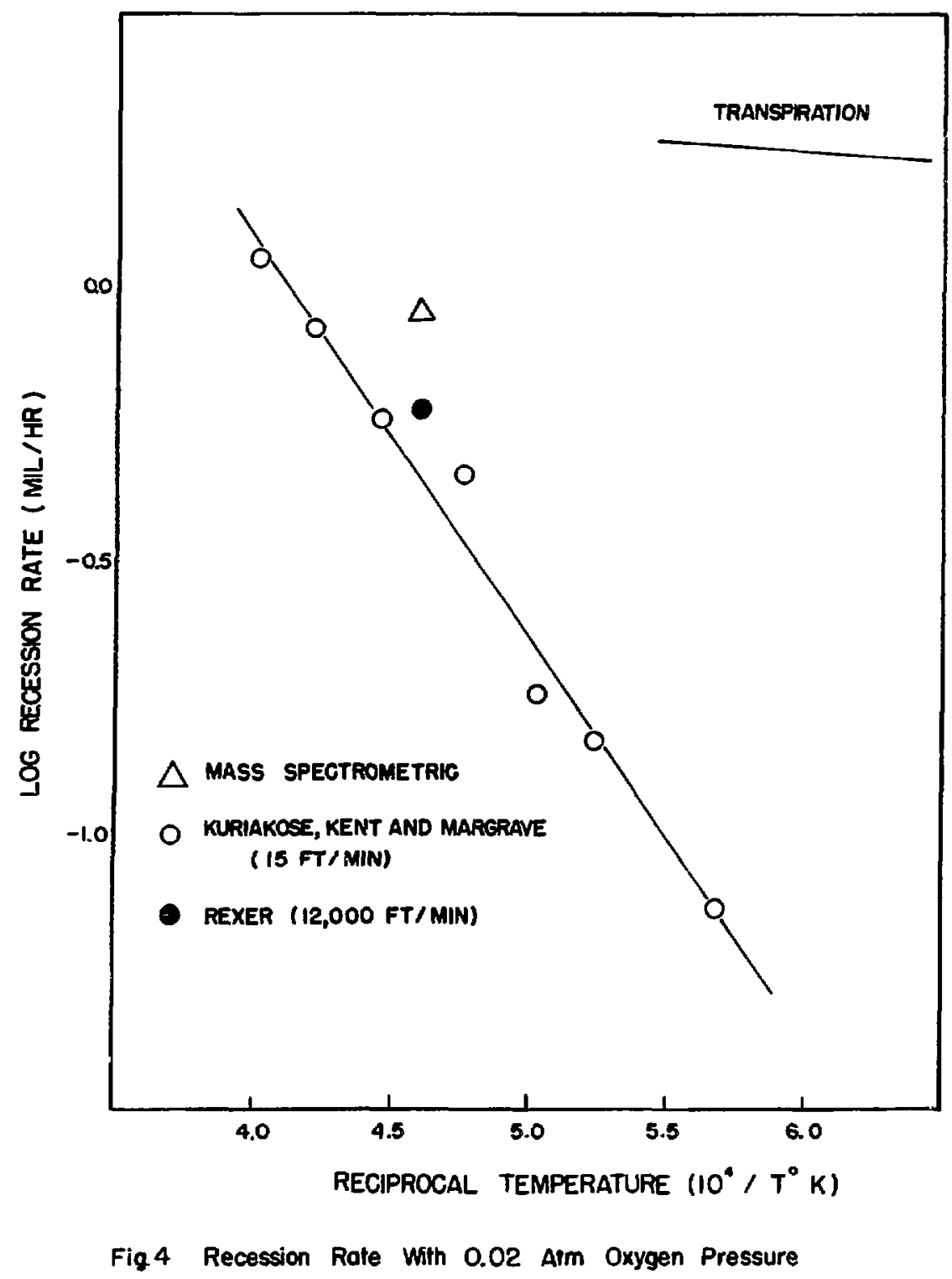

\$ U.8. GOVERNMENT PRINTING OFFICE: 1079 - 704.27\%/4

CM:448(35) 